CLAUDIA DE ASEVEDO BUKOWSKI

Arquitetura brasileira contemporânea: um panorama da atualidade a partir do estudo de residências em Curitiba

São Paulo

2012 


\title{
CLAUDIA DE ASEVEDO BUKOWSKI
}

Arquitetura brasileira contemporânea: um panorama da atualidade a partir do estudo de residências em Curitiba

\author{
Dissertação apresentada no Curso de \\ Mestrado da Faculdade de Arquitetura e Urbanismo da \\ Universidade de São Paulo \\ para a obtenção de título de \\ Mestre em Arquitetura \\ Área de concentração: \\ Projeto de Arquitetura \\ Orientador: Prof. Dr. \\ Miguel Alves Pereira
}

\section{São Paulo}


AUTORIZO A REPRODUÇÃO E DIVULGAÇÃO TOTAL OU PARCIAL DESTE TRABALHO, POR QUALQUER MEIO CONVENCIONAL OU ELETRÔNICO, PARA FINS DE ESTUDO E PESQUISA, DESDE QUE CITADA A FONTE.

E-MAIL DO AUTOR: c.bukowski@gmail.com

E-MAIL DO ORIENTADOR: miguelpe@uol.com.br

Bukowski, Claudia de Asevedo

B932a Arquitetura brasileira contemporânea: um panorama da atualidade a partir do estudo de residências em Curitiba / Claudia de Asevedo Bukowski. - São Paulo, 2012.

190 p. : il.

Dissertação (Mestrado - Área de Concentração: Projeto de Arquitetura) - FAUUSP.

Orientador: Miguel Alves Pereira

1.Arquitetura moderna - Curitiba(PR) 2.Edifícios residenciais 3.Projeto de arquitetura I.Título

CDU 72.036(816.21) 
Nome: BUKOWSKI, Claudia de Asevedo

Título: Arquitetura brasileira contemporânea: um panorama da atualidade através do estudo de residências em Curitiba

Dissertação apresentada no Curso de Mestrado da Faculdade de Arquitetura e Urbanismo da Universidade de São Paulo para a obtenção de título de Mestre em Arquitetura

Aprovado em:

Banca Examinadora

Prof. Dr. Instituição:

Julgamento: Assinatura:

Prof. Dr. Instituição: Julgamento: Assinatura:

Prof. Dr. Instituição:

Julgamento: Assinatura: 


\section{AGRADECIMENTOS}

Agradeço a todos que, de uma maneira ou de outra, contribuíram para a realização deste trabalho.

Ao orientador, Professor Doutor Miguel Alves Pereira, pela competência na condução deste trabalho, prezando por sua consistência e relevância.

Aos arquitetos do Andrea Berriel, Daniela Busarello, Maurício Melara, Gustavo Pinto, e aos escritórios de arquitetura UNA Arquitetos, Studio Bertoldi, Z Arquitetura e Central de Projetos, por disponibilizarem desenhos, imagens e fotografias de seus projetos para este trabalho.

Aos amigos Rafael Dal-Ri e Ana Carolina Mazzarotto, pelas importantes discussões e troca de ideias enriquecendo minha visão sobre arquitetura.

Aos professores da Faculdade de Arquitetura e Urbanismo da USP, pela competência e oportunidade das discussões travadas ao longo do curso.

Aos professores Cleusa de Castro e Humberto Mezzadri, do Curso de Arquitetura da UFPR, pela inspiração e apoio. 


\section{RESUMO / PALAVRAS-CHAVE}

Esta dissertação apresenta um estudo da arquitetura contemporânea em Curitiba, realizado a partir da análise de oito projetos residenciais. Para este trabalho, foi desenvolvida uma metodologia de análise arquitetônica, apresentada juntamente com os pressupostos teóricos da pesquisa. A dissertação tem como objetivo avaliar o panorama atual da arquitetura da cidade em busca de tendências predominantes.

A pesquisa foi dividida em três etapas: uma teórica, uma histórica, e uma analítica. A primeira corresponde ao capítulo dois e estabelece os marcos teóricos essenciais à elaboração da pesquisa, assim como o roteiro metodológico a ser utilizado nas análises das obras construídas. A segunda, desenvolvida nos capítulos três e quatro, tem como objetivo delinear um breve histórico da arquitetura de Curitiba e apresentar as principais tendências da arquitetura contemporânea internacional. Por fim, a terceira etapa deste estudo compreende a analise de oito residências construídas na capital paranaense após os anos 2000.

A partir deste estudo, procurou-se evidenciar as permanências e continuidades da nova arquitetura de Curitiba, buscando identificar as tendências predominantes - estéticas, ambientais, tecnológicas - com 0 objetivo de compreender o cenário arquitetônico atual da cidade e sua relação com a produção brasileira e internacional.

Por fim, esse trabalho busca identificar obras criativas e relevantes no panorama da cidade e revelar a essência desta arquitetura, com objetivo de ampliar as discussões acerca da arquitetura de Curitiba e sua pertinência.

Palavras chave: Arquitetura contemporânea - Arquitetura curitibana Residências Unifamiliares - Projeto de arquitetura 


\section{ABSTRACT}

This research presents a study on Curitiba's contemporary architecture based on the analysis of eight residential projects. It develops an architectural analysis methodology presented with the theoretical basis of the research. It tries to evaluate a current perspective about the city's architecture, searching for its main trends.

This study was divided in three distinct parts: a theoretical, a historical, and an analytical. The first one corresponds to chapter two of this volume and looks for establish the basic theoretical landmarks for the elaboration of the research, as well as the methodological script used in the analysis of the buildings. Part two, developed in chapter three, presents a brief historical review from Curitiba's architecture. Finally, the third part of this research comprehends the analysis of eight houses built in Curitiba after the year 2000.

This study identifies the permanent aspects of Curitiba's new architecture, searching for main trends - aesthetic, environmental, technological - trying to understand the contemporary architectural scenery from Curitiba and its ballast in the Brazilian an international architectural culture.

In conclusion, this research tries to identify creative and relevant constructions in Curitiba's overview, searching for permanent aspects in its architecture, in order to promote the debate about the city's architecture and its relevance.

Keywords: Contemporary architecture - Architecture in Curitiba - Single family houses - Architecture project 


\section{LISTA DE FIGURAS}

Figura 1 - Residência do Arquiteto Frederico Kirchgässner (1930)...............36

Figura 2 - Residência do Arquiteto Frederico Kirchgässner (1930): rua Jaime

Reis 37

Figura 3 - Residência Bernardo Kirchgässner (1936): vista frontal...............38

Figura 4 - Residência Nelson Justus (1945): vista frontal ...........................41

Figura 5 - Residência Nelson Justus (1945): cobertura de automóveis .........41

Figura 6 - Residência do Arquiteto Lolô Cornelsen (1949)...........................42

Figura 7 - Teatro Guaíra (1954) .................................................43

Figura 8 - Teatro Guaíra (1954): vista aérea..........................................44

Figura 9 - Centro Cívico, Palácio Iguaçu (1953): frente ............................46

Figura 10 - Centro Cívico, Palácio Iguaçu (1953): fundos...........................46

Figura 11 - Centro Cívico, Palácio Iguaçu (1953) ....................................47

Figura 12 - Residência João Luiz Bettega (1953) ...................................49

Figura 13 - Residência João Luiz Bettega (1953): terraço sobre a garagem .49

Figura 14 - Residência João Luiz Bettega (1953): interior ..........................50

Figura 15 - Residência da Arquiteta Maria Nadir de Carvalho (1975): frente.53

Figura 16 - Residência da Arquiteta Maria Nadir de Carvalho (1975)............54

Figura 17 - Residência do José Tadeu de Araújo (1975): frente....................55

Figura 18 - Residência do José Tadeu de Araújo (1975): interior ...................55

Figura 19 - Residência do Arquiteto Manoel Coelho (1982): frente................56

Figura 20 - Residência do Arquiteto Manoel Coelho (1982): fundos..............57

Figura 21 - Residência do Arquiteto Manoel Coelho (1982): interior..............57

Figura 22 - Residência do Arquiteto Oswaldo Navaro Neves (1977) .............59

Figura 23 - Residência do Arquiteto Oswaldo Navaro Neves (1977): detalhe troncos

Figura 24 - Residência do Arquiteto Oswaldo Navaro Neves (1977): vista

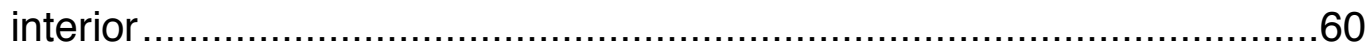

Figura 25 - Memorial dos 300 Anos de Curitiba (1994)............................61

Figura 26 - Universidade Livre do Meio Ambiente (1992) .........................62

Figura 27 - Universidade Livre do Meio Ambiente (1992): troncos...............62 
Figura 28 - Residência UNA em Curitiba: elevação frontal ............................84

Figura 29 - Residência UNA em Curitiba: perspectiva fundos .......................85

Figura 30 - Residência UNA em Curitiba: perspectiva frontal .......................85

Figura 31 - Residência UNA em Curitiba: vista lateral .................................86

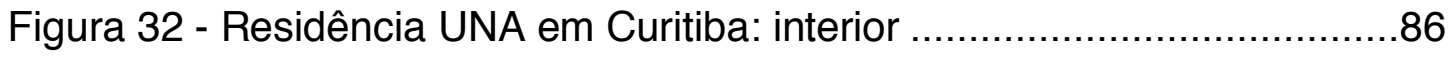

Figura 33 - Residência UNA em Curitiba: detalhe guarda-corpo ....................87

Figura 34 - Residência UNA em Curitiba: escada........................................87

Figura 35 - Residência UNA em Curitiba: sala de jantar ..............................88

Figura 36 - Residência UNA em Curitiba: planta pavimento inferior ...............88

Figura 37 - Residência UNA em Curitiba: planta pavimento térreo .................89

Figura 38 - Residência UNA em Curitiba: planta pavimento superior ............89

Figura 39 - Residência UNA em Curitiba: cortes........................................90

Figura 40 - Residência Casagrande Bertoldi: acesso principal .......................95

Figura 41 - Residência Casagrande Bertoldi: interior....................................96

Figura 42 - Residência Casagrande Bertoldi: acesso veículos ......................96

Figura 43 - Residência Casagrande Bertoldi: elevação lateral.......................97

Figura 44 - Residência Casagrande Bertoldi: perspectiva ............................97

Figura 45 - Residência Casagrande Bertoldi: interior..................................98

Figura 46 - Residência Casagrande Bertoldi: interior..................................98

Figura 47 - Residência Casagrande Bertoldi: vista lateral ...........................99

Figura 48 - Residência Casagrande Bertoldi: interior...................................99

Figura 49 - Residência Casagrande Bertoldi: interior................................100

Figura 50 - Residência Casagrande Bertoldi: sala de jantar .......................100

Figura 51 - Residência Casagrande Bertoldi: plantas .................................101

Figura 52 - Residência Casagrande Bertoldi: cortes e elevações................102

Figura 53 - Residência Atrio Arquitetura: geral ........................................107

Figura 54 - Residência Atrio Arquitetura: acesso principal.........................108

Figura 55 - Residência Atrio Arquitetura: acesso garagem .........................108

Figura 56 - Residência Atrio Arquitetura: detalhe aberturas.......................109

Figura 57 - Residência Atrio Arquitetura: fundos.....................................109

Figura 58 - Residência Atrio Arquitetura: piscina ....................................110

Figura 59 - Residência Atrio Arquitetura: interior ......................................110 
Figura 60 - Residência Atrio Arquitetura: fundos.

Figura 61 - Residência Atrio Arquitetura: implantação .................................111

Figura 62 - Residência Atrio Arquitetura: plantas e cortes ..........................112

Figura 63 - Residência Atrio Arquitetura: elevações ..................................113

Figura 64 - Casa Schaitza: vista geral ..............................................119

Figura 65 - Casa Schaitza: perspectiva ..............................................120

Figura 66 - Casa Schaitza: detalhe aberturas ........................................120

Figura 67 - Casa Schaitza: escada .....................................................121

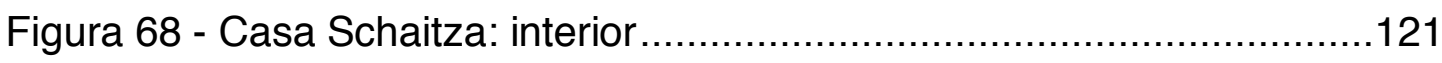

Figura 69 - Casa Schaitza: corredor interno..........................................122

Figura 70 - Casa Schaitza: vista interna .............................................122

Figura 71 - Casa Schaitza: vista fundos..............................................123

Figura 72 - Casa Schaitza: perspectiva externa.....................................123

Figura 73 - Casa Schaitza: garagem...................................................124

Figura 74 - Casa Schaitza: vista externa .............................................124

Figura 75 - Casa Schaitza: plantas térreo e primeiro pavimento...................125

Figura 76 - Casa Schaitza: planta pavimento superior e embasamento ......126

Figura 77 - Casa Schaitza: cortes ......................................................127

Figura 78 - Casa Schaitza: elevações.................................................128

Figura 79 - Casa JAeRR: perspectiva externa.......................................132

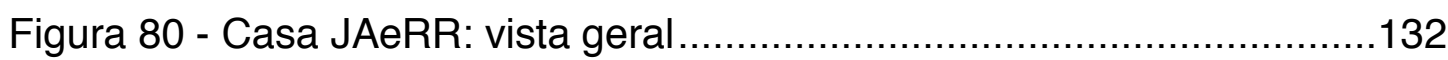

Figura 81 - Casa JAeRR: elevação lateral .............................................133

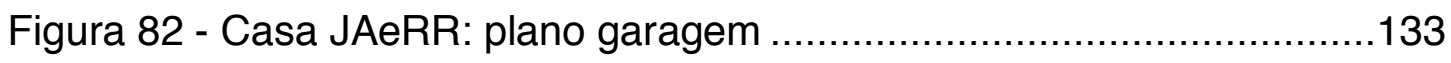

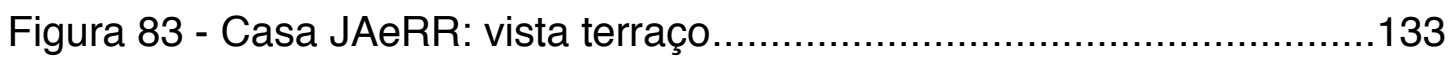

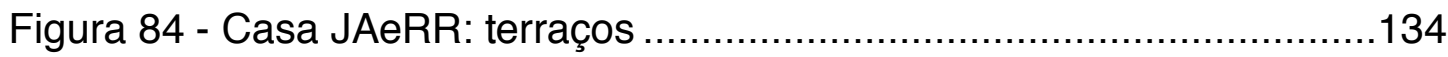

Figura 85 - Casa JAeRR: vista externa / detalhe piso jardim .......................134

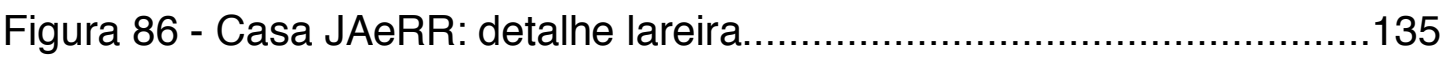

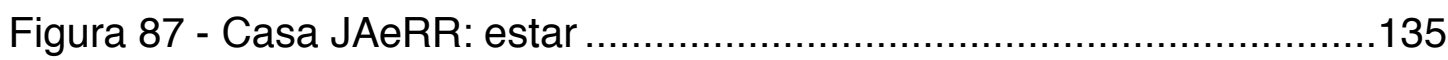

Figura 88 - Casa JAeRR: planta pavimento térreo...................................136

Figura 89 - Casa JAeRR: planta pavimento superior ................................136

Figura 90 - Casa JAeRR: cortes ......................................................137

Figura 91 - Residência Nunes: acesso principal .....................................141 
Figura 92 - Residência Nunes: detalhe entrada .....................................142

Figura 93 - Residência Nunes: perspectiva lateral....................................142

Figura 94 - Residência Nunes: facha lateral ...........................................143

Figura 95 - Residência Nunes: varanda quartos .......................................143

Figura 96 - Residência Nunes: detalhe cobertura ....................................144

Figura 97 - Residência Nunes: estar........................................................

Figura 98 - Residência Nunes: jantar .....................................................145

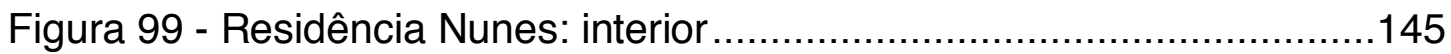

Figura 100 - Residência Nunes: implantação...........................................146

Figura 101 - Residência Nunes: planta primeiro pavimento.........................147

Figura 102 - Residência Nunes: planta segundo pavimento .......................147

Figura 103 - Residência Nunes: planta terceiro pavimento..........................147

Figura 104 - Casa Almirante Tamandaré: entorno .....................................152

Figura 105 - Casa Almirante Tamandaré: perspectiva externa .....................153

Figura 106 - Casa Almirante Tamandaré: construção existente …...............153

Figura 107 - Casa Almirante Tamandaré: construção anexa........................154

Figura 108 - Casa Almirante Tamandaré: vista lateral...............................154

Figura 109 - Casa Almirante Tamandaré: interior ...................................155

Figura 110 - Casa Almirante Tamandaré: detalhe escada..........................155

Figura 111 - Casa Almirante Tamandaré: engrenagem original....................156

Figura 112 - Casa Almirante Tamandaré: detalhe escada...........................156

Figura 113 - Casa Almirante Tamandaré: tesouras aparentes.....................157

Figura 114 - Casa Almirante Tamandaré: piso envidraçado .......................157

Figura 115 - Casa Almirante Tamandaré: cozinha..................................158

Figura 116 - Casa Almirante Tamandaré: pavimento térreo ……...............158

Figura 117 - Casa Almirante Tamandaré: sótão ......................................159

Figura 118 - Casa Almirante Tamandaré: sótão ……………………….....159

Figura 119 - Casa Almirante Tamandaré: vista externa..............................160

Figura 120 - Casa Almirante Tamandaré: entorno ....................................160

Figura 121 - Casa Almirante Tamandaré: planta subsolo ............................161

Figura 122 - Casa Almirante Tamandaré: planta pavimento térreo................161

Figura 123 - Casa Almirante Tamandaré: planta pavimento superior ...........161 
Figura 124 - Casa Almirante Tamandaré: corte ……..............................162

Figura 125 - Casa Almirante Tamandaré: elevação frontal..........................162

Figura 126 - Casa Almirante Tamandaré: elevação lateral .........................162

Figura 127 - Residência Daniela Busarello: planta pavimento térreo............167

Figura 128 - Residência Daniela Busarello: planta primeiro pavimento ........168

Figura 129 - Residência Daniela Busarello: planta segundo pavimento ......168

Figura 130 - Residência Daniela Busarello: corte logitudinal .......................169

Figura 131 - Residência Daniela Busarello: vista geral..............................169

Figura 132 - Residência Daniela Busarello: entrada principal......................170

Figura 133 - Residência Daniela Busarello: perspectiva externa .................170

Figura 134 - Residência Daniela Busarello: terraços ..................................171

Figura 135 - Residência Daniela Busarello: detalhe estrutura metálica ........171

Figura 136 - Residência Daniela Busarello: hall..........................................172

Figura 137 - Residência Daniela Busarello: sala........................................172

Figura 138 - Residência Daniela Busarello: interior e bosque......................173

Figura 139 - Residência Daniela Busarello: sala de jantar...........................173

Figura 140 - Residência Daniela Busarello: detalhe .................................174

Figura 141 - Residência Daniela Busarello: cozinha.................................174 


\section{SUMÁRIO}

1. INTRODUÇÃO

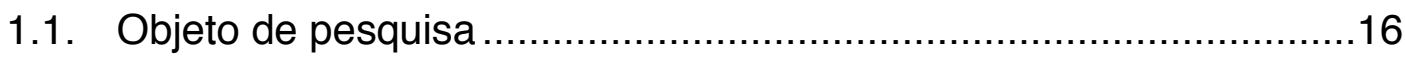

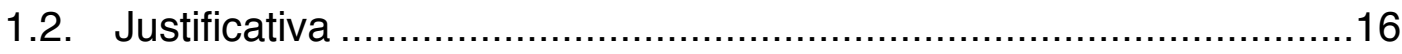

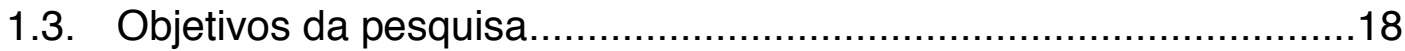

1.4. Metodologia de trabalho...........................................................

1.5. Sobre as motivações deste trabalho ............................................19

1.6. Apresentação da dissertação (Considerações iniciais)......................20

2. METODOLOGIA E PRESSUPOSTOS TEÓRICOS .................................21

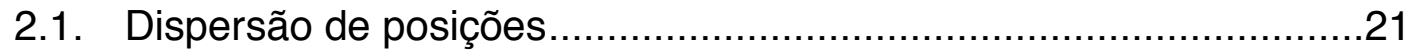

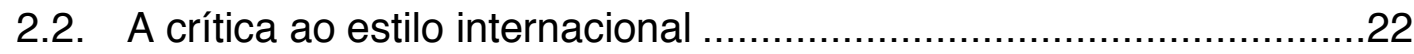

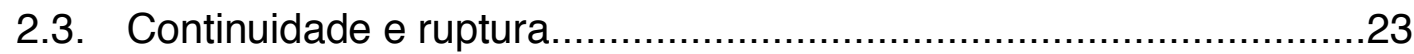

2.4. Pressupostos teóricos à elaboração de uma metodologia.................25

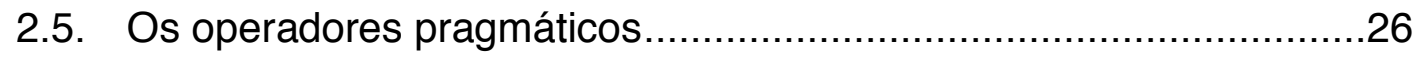

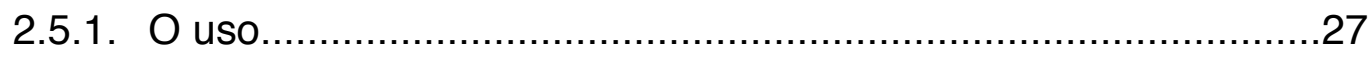

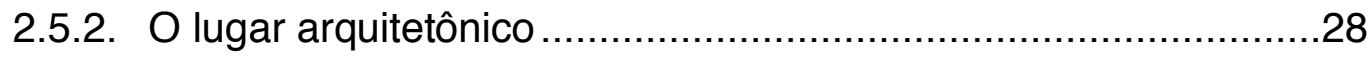

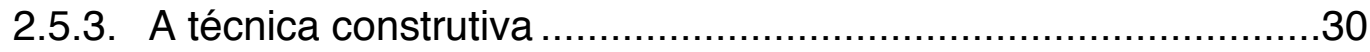

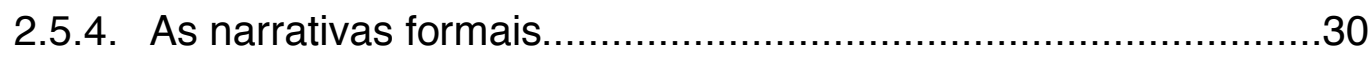

2.6. Definição da metodologia de análise ..............................................31

3. HISTÓRICO DA ARQUITETURA DE CURITIBA...................................34

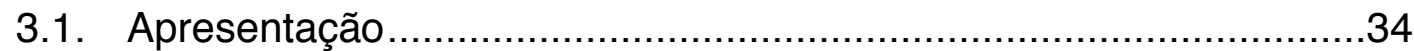

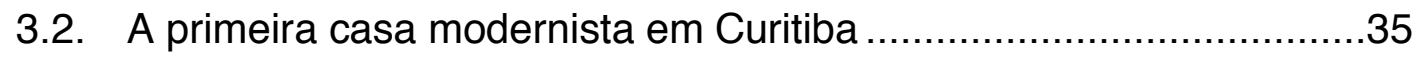

3.3. A influência de Le Corbusier e das vanguardas européias ................39

3.4. Expansão cafeeira e o governo Munhoz da Rocha...........................44

3.5. Década de 60 e a influência da arquitetura paulista .........................50

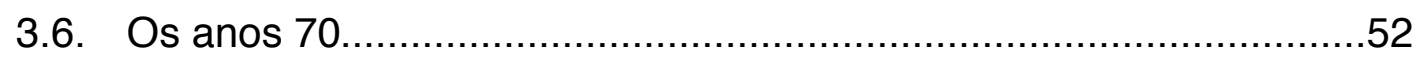

3.7. O surgimento de uma identidade ……............................................60 


\section{PRINCIPAIS TENDENCIAS DA ARQUITETURA CONTEMPORANEA.63}

5. A SELEÇÃO DOS PROJETOS .......................................................78

5.1. A arquitetura de Curitiba na visão dos arquitetos...........................78

5.2. A divulgação em jornais, revistas e periódicos .............................80

5.3. A participação em concursos e premiações.....................................81

5.4. Escolha final das obras .................................................... 82

6. UNA ARQUITETOS: RESIDÊNCIA EM CURITIBA...............................84

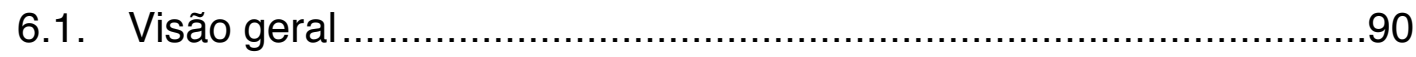

6.2. Implantação e relação com o entorno ...........................................91

6.3. Programa de atividades ...................................................91

6.4. Partido arquitetônico ........................................................92

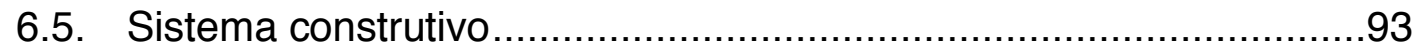

6.6. Intenção Plástica..................................................................93

7. STUDIO BERTOLDI: CASA DA PEDREIRA (CASAGRANDE BERTOLDI) 95

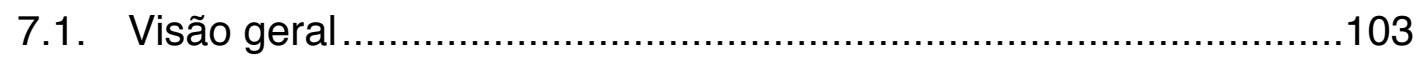

7.2. Implantação e relação com o entorno .........................................103

7.3. Programa de atividades ................................................ 104

7.4. Partido arquitetônico ...................................................... 105

7.5. Sistema construtivo................................................................ 105

7.6. Intenção Plástica..........................................................106

8. ATRIO ARQUITETURA: CASA NVL ..............................................107

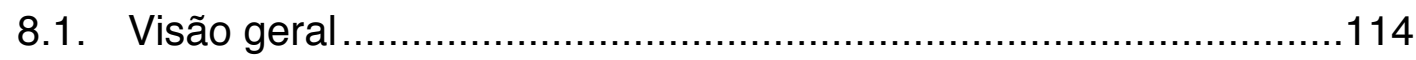

8.2. Implantação e relação com o entorno ........................................114

8.3. Programa de atividades .......................................................... 115

8.4. Partido Arquitetônico........................................................116

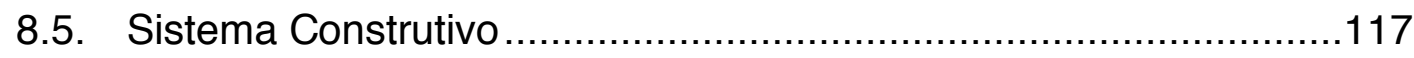

8.6. Intenção Plástica................................................................117

9. ANDREA BERRIEL: CASA SCHAITZA .........................................119 


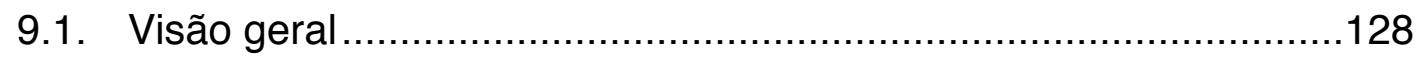

9.2. Implantação e relação com o entorno ………………….................129

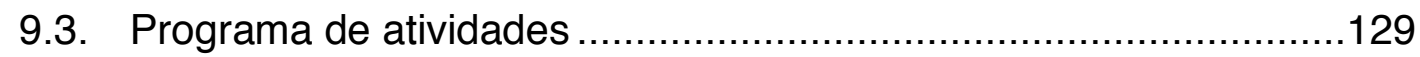

9.4. Partido arquitetônico .............................................................130

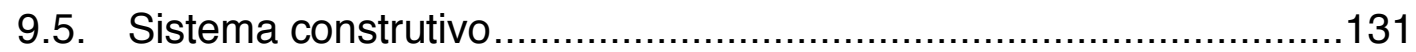

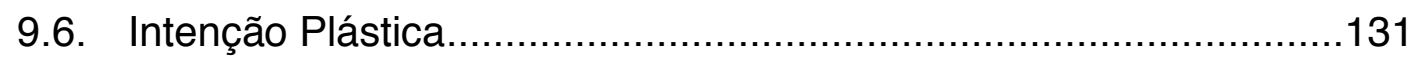

10. Z ARQUITETURA (SLOMP BUSARELLO): CASA JAERR.................132

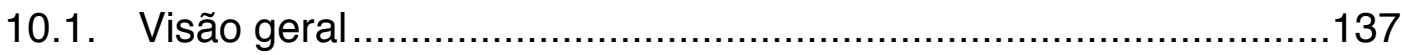

10.2. Implantação e relação com o entorno .........................................138

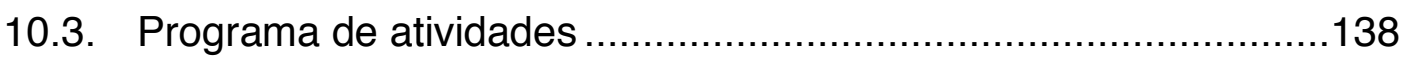

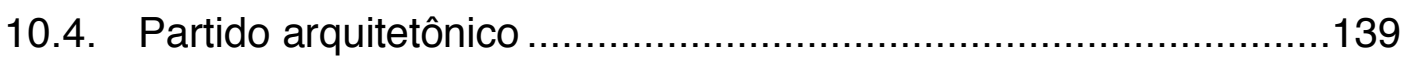

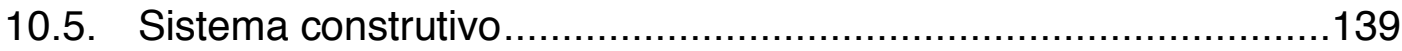

10.6. Intenção Plástica...................................................................140

11. CENTRAL DE PROJETOS: RESIDÊNCIA NUNES ............................141

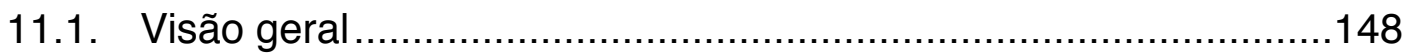

11.2. Implantação e relação com o entorno ........................................148

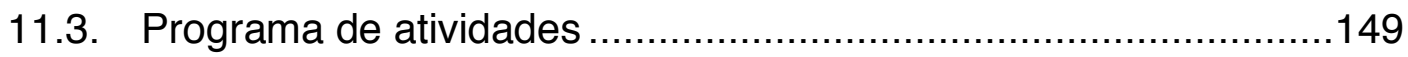

11.4. Partido arquitetônico ............................................................149

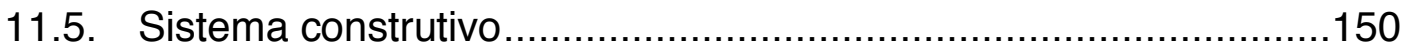

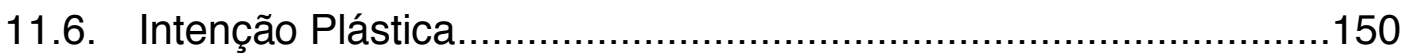

12. GUSTAVO PINTO: RECICLAGEM ANTIGO MOINHO .......................152

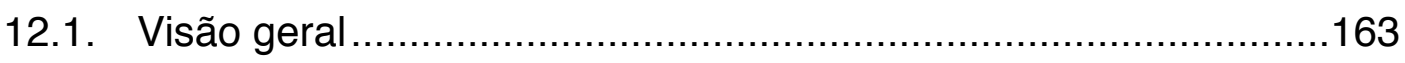

12.2. Implantação e relação com o entorno .........................................163

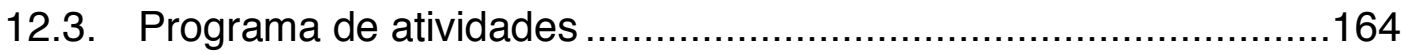

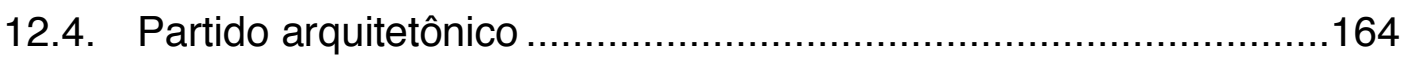

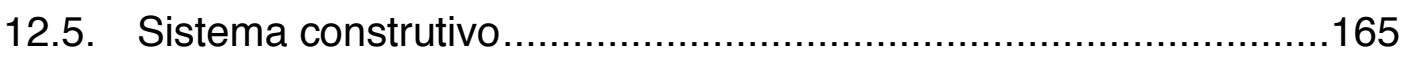

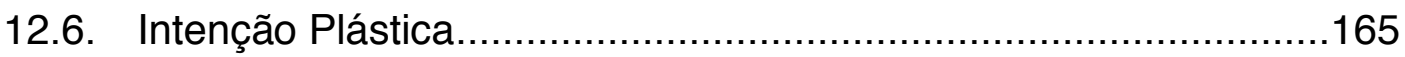

13. DANIELA BUSARELLO: RESIDÊNCIA DA ARQUITETA ...................167

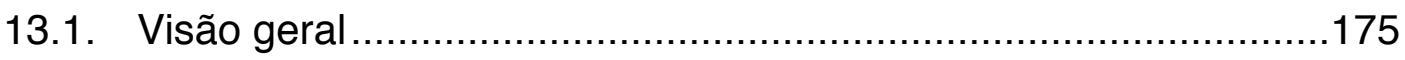

13.2. Implantação e relação com o entorno ........................................175 


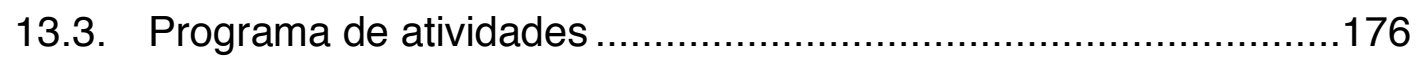

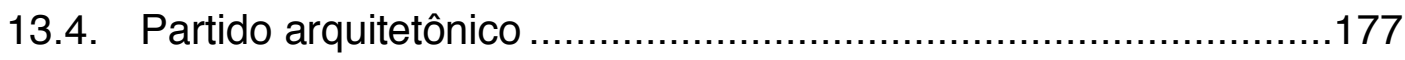

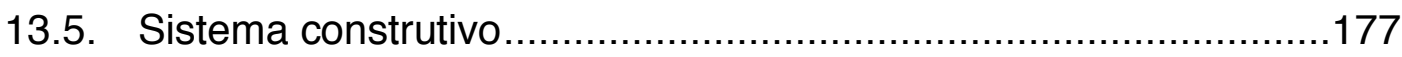

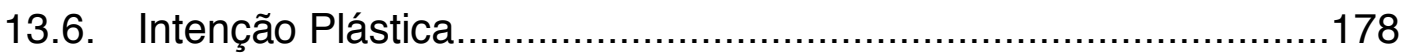

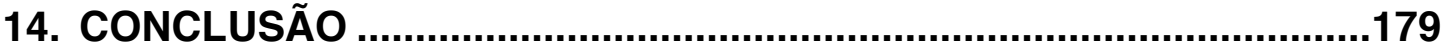

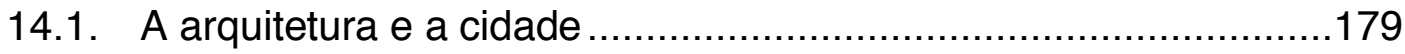

14.2. A escolha das residências .......................................................180

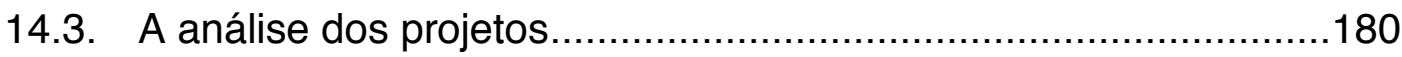

14.4. Curitiba e o debate teórico internacional....................................181

14.5. Considerações finais.................................................................185

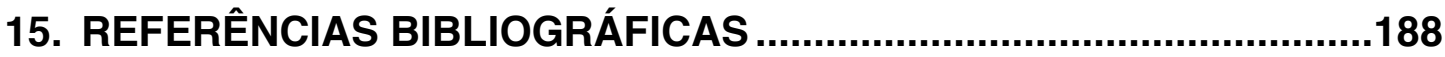




\section{INTRODUÇÃO}

\subsection{Objeto de pesquisa}

O objeto de estudo desta pesquisa é a arquitetura de tipologia residencial construída na cidade de Curitiba a partir do ano 2000.

\subsection{Justificativa}

A intenção deste trabalho é constituir um panorama da arquitetura contemporânea de Curitiba, através da análise projetual da produção a partir do ano 2000, mais especificamente da tipologia residencial, com o objetivo de compreender e identificar as principais tendências da atualidade e os possíveis rumos desta arquitetura.

\footnotetext{
Hoje, no início do século XXI, podemos afirmar que, apesar das duras críticas e do ceticismo que aparecem nas opiniões de renomados teóricos, existe um desenvolvimento arquitetônico e urbanístico brasileiro que, mesmo não sendo difundido como merece no mundo, tem a sua própria personalidade e caracterização, tanto no contexto latino-americano como mundial. ${ }^{1}$
}

As leituras críticas da arquitetura no Brasil, em sua grande maioria, dedicam-se ao estudo da produção entre os anos 30 e 60, marcada pela originalidade e criatividade que levaram a arquitetura nacional a ser reconhecida e valorizada no mundo todo. Por outro lado, estudos sobre a condição atual ainda são raros, apesar de renomados teóricos (citados a seguir) defenderem a existência de um desenvolvimento arquitetônico e urbanístico brasileiro com personalidade e caracterização próprias, tanto no contexto latino-americano como mundial.

Durante as duas décadas de regime militar no Brasil, a discussão e crítica arquitetônica praticamente inexistiram, sendo retomada apenas no final

\footnotetext{
${ }^{1}$ Segre, Roberto. Arquitetura Brasileira Contemporânea. Petrópolis, Viana \& Mosley, 2003.
} 
do século XX. Revistas especializadas - por exemplo, AU, Projeto, Arquitetura e Urbanismo - publicações independentes - vinculadas ou não a universidades - e alguns sites na internet documentaram alternativas formais e conceituais que acompanharam a dinâmica estilística e o debate teórico no exterior. Críticos e teóricos como Roberto Segre, Hugo Segawa, Carlos Eduardo Dias Comas, Ruth Verde Zein, Maria Alice Junqueira Bastos, entre outros, foram responsáveis pelos poucos livros dedicados a um estudo mais aprofundado sobre a produção arquitetônica brasileira posterior ao período modernista.

\begin{abstract}
A despeito da sensação de esvaziamento teórico na arquitetura brasileira, ao longo da década de 1980 e mais claramente nos anos 1990, é possível perceber um corpo de ideias dominante, nas apreciações de projeto e no discurso teórico, constituindo um pensamento crítico/teórico nacional. ${ }^{2}$
\end{abstract}

A partir dos anos 90, a crítica contemporânea se deparou com uma geração de novos arquitetos que, ainda que através de exemplos pontuais e não caracterizando um movimento consolidado, destacam-se com ideias expressivas e renovadoras, distanciando-se dos esquematismos ideológicos e políticos, rejeitando o formalismo arbitrário, associado à brasilidade, o regionalismo folclórico e os modismos externos.

\begin{abstract}
A visão do que acontece na atualidade não pode ser registrada em preto e branco, negando a totalidade da produção nacional, mas procurar a existência de iniciativas que abram caminhos com uma perspectiva dialética e pluralista, em concordância com a complexidade e as contradições que se enquadram. ${ }^{3}$
\end{abstract}

Considerando a dificuldade em acessar restritas encomendas públicas ou privadas, outorgadas pelo sistema de licitações a escritórios consolidados, e ainda o escasso número de concursos públicos e os poucos que de fato se

\footnotetext{
${ }^{2}$ Bastos, Maria Alice Junqueira. Pós-Brasília. Rumos da Arquitetura Brasileira. São Paulo, Editora Perspectiva, 2003.

${ }^{3}$ Segre, Roberto. Arquitetura Brasileira Contemporânea. Petrópolis, Viana \& Mosley, 2003.
} 
concretizam, as possibilidades para construção de prédios expressivos, com ideias renovadoras, são muito reduzidas. A margem de ação ficou limitada a projetos de pequeno porte, nas prefeituras, estabelecimentos comerciais, reforma de interiores, e sobretudo residências particulares.

Através da busca e do entendimento de exemplos relevantes de tipologia residencial, será possível identificar estratégias projetuais e afinidades existentes entre as obras selecionadas, buscando a identidade $\mathrm{e}$ características particulares da arquitetura contemporânea desenvolvida em Curitiba e no Brasil.

\subsection{Objetivos da pesquisa}

O objetivo geral desta pesquisa é identificar e analisar obras recentes de tipologia residencial em Curitiba que se destaquem pelas suas qualidades projetuais, delimitando um panorama da arquitetura atual na cidade e sua relação com a produção arquitetônica do país. Os objetivos específicos são:

- Investigar a condição da produção atual, buscando identificar as tendências predominantes.

- Contextualizar a produção da arquitetura curitibana contemporânea em relação às tendências estilísticas do restante do país e o debate teórico internacional.

\subsection{Metodologia de trabalho}

$\mathrm{Na}$ primeira etapa deste trabalho, foram selecionadas as residências que serão objeto de estudo. A pré-seleção das obras foi feita através de três fontes de informação:

- Entrevista com arquitetos e professores das principais escolas de arquitetura de Curitiba para que indicassem projetos residenciais considerados relevantes para este estudo. 
- Pesquisa bibliográfica buscando identificar obras e arquitetos que se destacaram a partir da década de 90 pela originalidade e comprometimento com uma arquitetura de qualidade.

- Análise de concursos e premiações que selecionaram obras realizadas em Curitiba ou por arquitetos curitibanos particularmente relevantes no contexto atual.

Realizada a pré-seleção, o material coletado foi analisado e as residências, a serem estudadas de forma mais detalhada, foram selecionadas. Propõe-se analisar estas residências sob os seguintes aspectos:

- Visão Geral

- Implantação e Relação com o Entorno

- $\quad$ Programa de Atividades

- $\quad$ Partido Arquitetônico

- Sistema Construtivo

- Intenção Plástica

Feito o estudo individual das residências, foi desenvolvida uma análise comparativa entre as obras, buscando afinidades existentes - plásticas, técnicas, construtivas e ambientais - com o objetivo de identificar as tendências atuais predominantes na arquitetura de Curitiba.

\subsection{Sobre as motivações deste trabalho}

A escolha da tipologia residencial como objeto de estudo tem como objetivo mostrar os discursos arquitetônicos dos arquitetos, apontando seus princípios compositivos, construtivos, tecnológicos, formais e estéticos, expressos e manifestados nas diversas linguagens e tendências da arquitetura contemporânea. A residência unifamiliar é a tipologia arquitetônica na qual o arquiteto tem maior liberdade para expressar e desenvolver suas ideias e ideais de projeto. 
As obras aqui selecionadas apresentam diferentes aspectos e tendências da arquitetura de Curitiba, evidenciando a sua pluralidade. Ao referenciar o conceito e a poética destas obras com arquiteturas desenvolvidas em outras regiões do país, este trabalho deixa de ser um estudo específico arquitetura de Curitiba para mostrar um panorama da arquitetura brasileira.

O objeto de estudo deste trabalho são casas localizadas em Curitiba, especificamente aquelas construídas a partir dos anos 2000. Espera-se que a análise destes projetos possibilite identificar algumas ideias mais significativas desta arquitetura, marcada por uma grande diversidade posturas, oriundas a partir dos confrontos entre modernidade e pós-modernidade.

\subsection{Apresentação da dissertação (Considerações iniciais)}

Esta dissertação foi dividida em três etapas: teórica, histórica e analítica. A primeira etapa corresponde ao capítulo dois e estabelece os marcos teóricos fundamentais à elaboração da pesquisa e o roteiro metodológico aplicado nas análises das residências. A segunda etapa, desenvolvida nos capítulos três e quatro, tem como objetivo delinear um breve histórico da arquitetura de Curitiba e apresentar as principais tendências da arquitetura contemporânea internacional. Por fim, na terceira etapa, correspondente aos capítulos cinco a treze, serão analisadas oito residências construídas na cidade dentro do período anteriormente citado.

A diversidade e quantidade de projetos residenciais concretizados em Curitiba na última década impedem que esta produção seja contemplada em sua totalidade. Este estudo não tem como objetivo a catalogação historiográfica completa dos projetos residenciais do período estudado, e sim fornecer bases fundamentais para a compreensão deste período e material para pesquisas futuras.

As análises deste estudo procuram avaliar as residências em seus aspectos formais, compositivos, técnicas e materiais construtivos, relação com o entorno e partido arquitetônico. Para seleção das obras a serem analisadas, prevaleceu o critério de disponibilidade dos arquitetos e proprietários em 
colaborar com a pesquisa, assim como acesso irrestrito aos projetos de execução, textos documentais e acesso livre à residência. A seleção das obras buscou evidenciar a diversidade das manifestações arquitetônicas e as diferentes abordagens poéticas da arquitetura da cidade.

\section{METODOLOGIA E PRESSUPOSTOS TEÓRICOS}

Entende-se aqui que a arquitetura de Curitiba nos anos 2000 é reflexo dos debates culturais das últimas décadas e do confronto de discursos entre modernidade e pós-modernidade. As críticas promovidas pela pósmodernidade influenciaram toda a arquitetura brasileira, que reagiu a estas questões - concordando ou discordando destes discursos - assumindo posições frente a este debate e materializando suas próprias manifestações através de obras arquitetônicas.

\subsection{Dispersão de posições}

Durante as duas décadas de regime militar no Brasil, a discussão e crítica arquitetônica praticamente inexistiu. Nos anos 70, de acordo com Hugo Segawa em seu livro Arquiteturas no Brasil: 1900-1990, a arquitetura ficou marcada pela ausência de críticas e críticos, sem relação com o entorno ou usuários, ao contrário do nosso primeiro modernismo. Caracterizava-se como uma arquitetura independente do programa, marcada pelo exibicionismo estrutural, grandes panos de vidros, competição pelos maiores vãos, imitações dos conteúdos elaborados durante o período áureo do modernismo brasileiro. Ainda segundo Segawa, já nos anos 80 sentia-se que eram necessárias revisões no discurso e prática arquitetônica. Entretanto, este debate só ocorreu no Brasil no final da década de 80 e principalmente durante década seguinte.

O pós-modernismo tardio brasileiro contribuiu para abertura do debate da arquitetura moderna brasileira, contribuindo para uma maior tolerância em relação a diferentes posicionamentos. Ressaltava-se a necessidade de um diálogo com o contexto urbano e ambiental na implantação dos edifícios e uma 
preocupação maior com o usuário. Substituía-se a postura determinista e unívoca da tendência anterior por um discurso mais analítico, simbólico, que aceitava e até mesmo incorporava a ambiguidade como procedimento de projeto.

A crítica pós-modernista no Brasil resultou na crítica das interpretações racionalizadoras, no questionamento dos modelos e dos grandes sistemas de pensamento. Contudo, para Hugo Segawa essa reavaliação de conceitos e surgimento de novas formas de pensar e fazer arquitetura não resultou na implantação do pós-modernismo no Brasil:

\footnotetext{
A atual contestação à arquitetura moderna brasileira atinge seus mitos, não seus princípios. Essa crítica tem fundamentos e é precisa em vários aspectos, mas por enquanto caracteriza-se mais como uma atitude de reação a uma precisa modernidade, sem apresentar uma alternativa concreta com espessura conceitual consistente. ${ }^{4}$
}

\subsection{A crítica ao estilo internacional}

A crítica pós-modernista em relação ao chamado estilo internacional é particularmente direcionada para o período que se inicia a partir da segunda metade da década de 40, quando o movimento adquire características tecnocráticas, visualmente pobres e indiferentes ao usuário.

Edson Mahfuz ${ }^{5}$ expôs um resumo das ideias presentes no estilo internacional e a crítica pós-modernista a estes valores. Entre os princípios que regiam o estilo internacional, destacou: rompimento com a história antes de 1920; pureza formal; ideias de flexibilidade; o programa e a estrutura como únicos definidores das formas arquitetônicas; formalmente, prevaleciam volumes simples e retangulares, janelas em fita, fachada cortina; coberturas planas, esqueletos estruturais, balanços; espacialmente, espaços

\footnotetext{
${ }^{4}$ SEGAWA, Hugo. Arquiteturas no Brasil 1900-1990. São Paulo: Editora da Universidade de São Paulo, 1997.

${ }^{5}$ MAHFUZ, Edson. Quem tem medo do pós-modernismo? São Paulo: revista Projeto n. 101, pg. 132.
} 
interpenetrantes, planta livre, ênfase em planos curvos; no desenho urbano, prevalecia a divisão funcional da cidade, o sistema viário como gerador da forma urbana e as habitações em prédios altos e bem separados.

Já a crítica pós-modernista defendia: o fim da homogeneização arquitetônica resultantes das soluções universais; recuperação da escala humana e do significado do espaço público; melhores soluções para a questão da habitação coletiva - que eliminava o antigo para construir edifícios novos com qualidade inferior; busca de novas linguagens, menos puristas e auto referenciadas; novas metodologias de projeto que não se baseiam apenas nos princípios do determinismo pragmático e do expressionismo estrutural; desprendimento em relação à ideia de originalidade absoluta.

Para Edson Mahfuz, o pós-modernismo no Brasil foi marcado pelo pluralismo de pensamentos e correntes, configurando-se como uma etapa da evolução do modernismo. Não antagoniza o movimento moderno como um todo, e sim o chamado estilo internacional.

\subsection{Continuidade e ruptura}

Estas críticas foram delineadas a partir do segundo pós-guerra e destruíram as bases do movimento moderno, abrindo caminho para novas ideias e teorias sobre o fazer e projetar arquitetônico.

Alan Coulquhoun 6 , em seu ensaio "Actitudes críticas posmodernas", afirmou que uma das diretrizes fundamentais do Movimento Moderno é o funcionalismo, interpretado de diferentes formas por cada uma das escolas alemã, russa, holandesa, francesa - e pelos arquitetos individualmente. Apesar de algumas ambiguidades entre diferentes linhas de interpretação - por exemplo, a linha mecânica de Le Corbusier em oposição à linha orgânica representada por Frank Lloyd Wright - observa-se que as vanguardas clássicas tinham em comum a aplicação funcional da forma abstrata. Embora a funcionalidade fosse um conceito relevante, desde o final do século XVIII, para

\footnotetext{
${ }^{6}$ COULQUHOUN, Alan. Modernidad y tradición clássica. Trad. Ramón Martinez Castellote. Madrid, Ediciones Júcar, 1991.
} 
o movimento moderno esta ideia veio obrigatoriamente dissociada de todo e qualquer rastro de contextualidade ou decoro, buscando a eliminação de tudo que tivesse qualquer relação com costume social ou formas arbitrárias.

Desta forma, a arquitetura moderna privilegiou a razão, a abstração, a ciência e a técnica. O moderno deveria representar suas próprias ideias culturais, únicas e livres de qualquer influência histórica ou relacionada com qualquer tradição. Acreditava-se ainda que as formas modernas pudessem ser criadas racionalmente a partir da necessidade conhecida. Esta maneira positivista e cientificista de entender cultura e sociedade se tornaria um dos principais pontos da crítica pós-moderna, realizada através de dois modelos distintos: o progressista e o culturalista.

Para Françoise Choay $^{7}$, o modelo progressista entendia a pósmodernidade como uma continuação da modernidade, mantendo diversas ideias relacionadas com a modernidade (em particular a noção de ruptura histórica), mas transformando-as de acordo com suas críticas e revisões. Em oposição, o culturalista defendia uma total dissociação da modernidade e uma crítica a esta em favor da tradição.

Neste panorama diversificado de ideias, posições e possibilidades, o pós-modernismo abandona a busca por um estilo único e dominante e aceita o pluralismo como uma de suas características. De acordo com Josep Maria Montaner ${ }^{8}$, no decorrer dos anos 90, estas diferentes posturas arquitetônicas desenvolveram consistência crítica e embasamento teórico suficiente para configurarem correntes arquitetônicas propriamente ditas. Montaner ressalta ainda que a maioria dos arquitetos relevantes deste período não se encaixa em apenas uma destas vertentes da nova arquitetura, mas oscilam de forma relativamente flexível entre uma e outra, buscando as melhores soluções para as condições e desafios específicos de cada projeto.

A arquitetura brasileira - e também a arquitetura de Curitiba desenvolvida no decorrer dos anos 90 e principalmente após os anos 2000 ,

\footnotetext{
${ }^{7} \mathrm{CHOAY}$, Françoise. O Urbanismo: utopias e realidades. Uma antologia São Paulo: revista Perspectiva, 1992.

${ }^{8}$ MONTANER, Josep Maria. Después del Movimiento Moderno. Arquitectura de la Segunda Mitad del Siglo XX. Barcelona: Gustavo Gili, 1993
} 
pode ser entendida como uma (re)tomada crítica diante destas questões. Neste sentido, faz-se necessária a construção de tópicos de análise que possibilitem contemplar estas questões, possibilitando a configuração de um panorama da arquitetura desenvolvida em Curitiba e sua relação com o resto do Brasil e principais correntes contemporâneas internacionais.

\subsection{Pressupostos teóricos à elaboração de uma metodologia}

Com o objetivo de definir uma metodologia de análise de projetos, adequada e coerente com o estudo proposto, foi feita a pesquisa em teses e dissertações que tratassem não somente da análise de residências unifamiliares, mas de projetos de arquitetura em geral. Identificou-se a necessidade de estabelecer pressupostos teóricos, que configurassem premissas básicas para esta análise e a definição de tópicos que possibilitassem a avaliação e comparação das obras selecionadas.

O primeiro pressuposto deste estudo é a existência de uma dimensão artística na arquitetura. Por ser uma forma de arte, que necessariamente deve atender a uma necessidade do homem, a arquitetura por vezes encontra pontos de vista antagônicos que tendem a dissociar forma de conteúdo. De um lado, existem aqueles que defendem que a forma na arquitetura é de importância secundária, estando submetida às necessidades técnicas e funcionais da obra em questão. De outro, encontramos aqueles que não consideram o conteúdo utilitário como parte do objeto artístico.

Entretanto, esta separação da obra em dois aspectos distintos não existe, uma vez que não é possível uma decomposição do objeto artístico em frações isoladas. Uma vez aceita a existência de uma dimensão artística no objeto arquitetônico e, simultaneamente, a sua dimensão utilitária, torna-se impossível à dissociação categórica entre forma e conteúdo pragmático.

O segundo pressuposto é a existência de elementos básicos, que poderiam ser identificados como bases inequívocas para a análise da arquitetura, em consequência da sua permanência ao longo da história. Independente do período ou particularidades críticas de uma determinada 
época, a obra arquitetônica invariavelmente busca soluções para algumas necessidades específicas: necessidades de ordem funcional, ou de criação de espaços necessários às atividades humanas; necessidades de ordem técnica, ou de viabilização física e material da obra; e ainda aquelas relacionadas com o lugar onde a obra está inserida e aspectos específicos do entorno imediato (topografia, orientação, etc.).

Desta forma, a arquitetura se diferencia das outras atividades artísticas por ter seu processo criativo limitado pelos fatores arquitetônicos de ordem pragmática, encontrando seu valor artístico e relevância da obra, na ação intencional do arquiteto sobre estes elementos, resultando na forma arquitetônica.

Sendo assim, apresentam-se a seguir os elementos identificados como bases seguras para a análise de um projeto arquitetônico e condicionantes do partido formal de uma obra de arquitetura.

\subsection{Os operadores pragmáticos}

De acordo com Kenneth Frampton ${ }^{9}$, a obra construída é resultado de três fatores, o topos, o typos, e o tectônico. $O$ topos seria o local onde a obra está inserida; o typos, a expressão do uso do partido formal adotado; e o tectônico os aspectos que dizem respeito à construção do edifício. Aceitando a nomenclatura proposta por Bruno Santa Cecília ${ }^{10}$, estes três condicionantes - 0 uso, o lugar e a técnica - serão chamados, daqui para frente, "operadores projetuais pragmáticos". Estes condicionantes são responsáveis pela definição do que Michael Graves ${ }^{11}$ chamou de "forma padrão" da obra, em oposição à "forma poética", definida pelos conteúdos artísticos da arquitetura e questões externas ao edifício, como sua relação com a sociedade e caráter simbólico.

\footnotetext{
${ }^{9}$ FRAMPTON, Kenneth, MALGRAVE, Harry Francis. Studies in tectonic culture: the poetics of construction in nineteenth and twentieth century architecture. Cambridge: MIT Press, 2001.

${ }^{10}$ SANTA CECÍLIA, Bruno Luiz Coutinho. Complexidade e Contradição na Arquitetura Brasileira: A Obra de Éolo Maia (Dissertação de Mestrado, Universidade Federal de Minas Gerais. Orientador: Prof. Dra. Maria Lúcia Malard). 2004.

${ }^{11}$ GRAVES, Michael. A case for figurative architecture, 1982. In NESBITT, Kate (editor). Theorizing a new agenda for architecture: an anthology for architectural theory 1965-1995. Nova lorque: Princeton Architectural Press, 1996.
} 
Embora algumas decisões projetuais não possam ser explicadas a partir de uma relação de causa e efeito, na tentativa de explicar a geração da forma de maneira objetiva, o trabalho de alguns arquitetos demonstra que a própria forma arquitetônica - ou os procedimentos que dão origem a esta - são capazes de gerar novas formas. Este sistema de composição pode ser tanto comprovado pela aplicação dos conceitos de tipo e tipologia, quanto pelas citações e colagens de elementos arquitetônicos explorados pelos arquitetos pós-modernos. Desta forma, entende-se que em alguns casos a própria forma arquitetônica pode ser considerada um operador projetual pragmático.

Segundo Mahfuz (2003), "o quaterno contemporâneo" - o programa, a construção, o lugar e as estruturas formais - seria o responsável pela criação da "forma pertinente" na arquitetura. Para Mahfuz, o programa, o lugar e a construção são dados do problema projetual, enquanto as estruturas formais uma vez que refletem na forma a resposta encontrada para as necessidades identificadas nos outros três itens - são consideradas parte de sua solução.

Uma vez definidos estes quatro operadores projetuais pragmáticos, torna-se necessária a análise de cada um destes, individualmente, demonstrando a sua influência em relação ao projeto do edifício e sua importância na determinação da forma arquitetônica da obra construída.

\subsubsection{O uso}

A arquitetura se difere das outras artes pela sua dimensão utilitária, pela função intrínseca à obra arquitetônica em atender uma função. Enquanto a obra de arte é criada sem qualquer uso específico, a arquitetura surge a partir da necessidade de criar espaços que atendam a determinadas atividades do homem. "A obra de arte é trazida ao mundo sem que haja nenhuma necessidade. A casa, por outro lado, satisfaz uma necessidade" (LOOS apud WILSON, 1986: 16).

No decorrer da história, diversos teóricos discorreram sobre a relação entre a forma arquitetônica e o uso do edifício, não raramente considerando a forma subordinada à função do edifício. Nesse aspecto, Vitruvio escreveu que o 
atributo utilitas seria alcançado com a repartição adequada dos espaços do edifício.

\footnotetext{
Porque parece ser preciso construir habitações urbanas diferentemente daquelas às quais afluem os produtos agrícolas; diferentemente das dos financistas; diferentemente das feitas agrícolas, diferentemente das feitas para os opulentos, para as pessoas refinadas e para os poderosos, por cujos conselhos a República é governada; e os agenciamentos serão feitos conforme o uso, e todos deverão convir os ocupantes do edifício. ${ }^{12}$
}

Desta forma, para Vitruvio um edifício é identificado pela sua função social, e não pela sua forma, como mais tarde foi proposto pelo movimento pós-moderno.

Palladio também considerava uma relação de reciprocidade entre a forma e a função do edifício. Para ele, novas funções precisariam de novas formas, o que limita a utilização da antiguidade como modelo. Para Viollet-le Duc, a arquitetura seria uma resposta a diversos problemas propostos pelo homem e pelo meio (VIOLLET-LE-DUC apud COLLINS, 1989: 132). De acordo com ele, o edifício é uma resposta adequada ao programa, aos materiais e técnicas construtivas, ao local, à cultura, ao clima e à época em que a obra se insere.

No início do século $\mathrm{XX}$, o movimento moderno outorgou um papel central à função na arquitetura. Sullivan afirmou que "a forma segue a função" e esta se tornaria uma das mais influentes doutrinas modernistas. (SULLIVAN apud KRUFT, 1994: 357). Posteriormente, também, seria um dos pontos mais criticados pelos pós-modernos, que passariam a defender o resgate cultural e uma relação mais estreita com a história e o lugar.

\subsubsection{O lugar arquitetônico}

\footnotetext{
${ }^{12}$ VITRUVIO, Marco Lucio. Da Arquitetura. São Paulo: Hucitec, 1999.
} 
Para Vitruvio (1999), era essencial a escolha adequada do sítio a fim de possibilitar não somente condições de salubridade à arquitetura, mas também, caráter adequado à obra, o que, na visão do arquiteto, garantiria a "conveniência" do edifício.

Conveniência, por sua vez, é o aspecto qualitativo da obra executada a partir do emprego de fatores de validade comprovada. Resulta da escolha do sítio, que em grego se diz thematísmos, da observação de costumes ou da natureza do entorno. ${ }^{13}$

Norbeg-Schulz ${ }^{14}$ criou o conceito de "genius loci", que seria o reconhecimento do "espírito do lugar": as características únicas do sítio direcionam a intervenção arquitetônica, dando origem a um entorno qualitativo. Para Montaner, o lugar diferencia-se do espaço pela presença da experiência.

Em pequena escala [o lugar] é entendido como uma qualidade do espaço interior que se materializa na forma, textura, cor, luz natural, objetos e valores simbólicos (...) Em grande escala, é interpretado como genius loci, como capacidade para fazer aflorar as pré-existências ambientais, como objetos reunidos no lugar, como articulação das diversas peças urbanas (praça, rua, avenida). Isto é, como paisagem característica. Uma ulterior e mais profunda relação entenderia o conceito de lugar, precisamente, como a correta relação entre a pequena escala do espaço interior e a grande escala da implantação. ${ }^{15}$

Desta forma, acredita-se que as características do lugar podem ser consideradas como diretrizes iniciais do projeto arquitetônico. $O$ aspecto qualitativo da obra é atingido não somente com a adequação funcional do

\footnotetext{
${ }^{13}$ VITRUVIO, Marco Lucio. Da Arquitetura. São Paulo: Hucitec, 1999.

${ }^{14}$ NORBERG-SCHULZ, Christian. Genius Loci - towards a phenomenology in architecture. New York: Rizzoli, 1984.

${ }^{15}$ MONTANER, Josep Maria. Después del movimiento moderno: arquitetura de la segunda mitad del sigo XX. Barcelona, Gustavo Gili, 1993.
} 
edifício à atividade a qual será destinado, mas também, com a sua adequação ao lugar, clima, topografia e características particulares do sítio, onde se insere.

\title{
2.5.3. A técnica construtiva
}

É a dimensão técnica que permite a manifestação física da arquitetura. Frampton (2001) enfatiza a dimensão concreta da arquitetura ao afirmar que a relação entre forma e técnica construtiva representa um compromisso ético e estético da arquitetura. O autor resgata a terminologia "tectônico" e "estereotômico" para definir a arquitetura como "poética da construção". Para Frampton (2001), o ofício da construção divide-se em duas etapas: a tectônica, que se refere à lógica construtiva, pela reunião e encaixe entre partes e objetos, e a estereotômica, na qual massa e volume são definidos, através da distribuição dos materiais.

O abade Marc-Anotine Laugier (WILSON, 1986), em sua concepção da cabana primitiva, considera suporte, viga e cobertura, como elementos essenciais, em contraposição às paredes e vedações, que seriam concessões à lógica estrutural tectônica pura. Ainda, para Frampton:

\begin{abstract}
A realização plena do potencial tectônico de um edifício estaria vinculada à sua capacidade de articular os aspectos poéticos e cognitivos de sua substância, reforçando a ideia inicial lançada no início deste tópico que não pretende a dissociação da forma arquitetônica de sua construção. ${ }^{16}$
\end{abstract}

\subsubsection{As narrativas formais}

Para Alan Coulquhoun (1991), depois de atendidas todas as demandas técnicas e funcionais do edifício, ainda existe um grande número de decisões a serem tomadas pelo arquiteto, nem sempre de ordem prática. Estas decisões

\footnotetext{
${ }^{16}$ FRAMPTON, Kenneth, MALGRAVE, Harry Francis. Studies in tectonic culture: the poetics of construction in nineteenth and twentieth century architecture. Cambridge: MIT Press, 2001.
} 
finais representam a intenção do arquiteto em relação ao edifício e definem a expressão formal da obra.

Pode-se dizer que as intenções artísticas da arquitetura se manifestam através das narrativas formais e das opções finais feitas pelo autor depois que as outras necessidades são satisfeitas.

As narrativas formais podem representar conteúdos abstratos da própria arquitetura e outras disciplinas - como nas vanguardas do início do século - ou expressar conteúdos figurativos em relação ao meio, onde estão inseridas, e seu entorno cultural - como em algumas reações pós-modernistas. Podem, ainda, reproduzir formas e narrativas de outras arquiteturas, sendo então denominadas meta-narrativas. Um exemplo disso são algumas posturas pós-modernistas que recorriam a colagens ou repetição de elementos clássicos da arquitetura, com o objetivo de criar uma relação mais estreita com o usuário, através do uso de simbologias conhecidas. Esta escolha depende do caráter que o arquiteto pretende para a obra e de suas convicções pessoais sobre a arquitetura.

\subsection{Definição da metodologia de análise}

As obras selecionadas neste estudo serão analisadas de acordo com estes operadores projetuais pragmáticos, identificados e descritos no capítulo anterior e que - por sua permanência histórica na arquitetura - podem ser considerados como elementos fundamentais para análise arquitetônica.

Sendo assim, o estudo das residências selecionadas contemplará estes operadores, através da subdivisão da análise nos seguintes tópicos:

\section{a) Visão Geral}

Este tópico tem como objetivo apresentar a obra que será analisada. Serão fornecidas informações gerais sobre o projeto (área, localização, data) informações sobre o arquiteto ou escritório autor da obra, justificativa da escolha da residência, detalhes específicos do programa solicitado pelo cliente. 


\section{b) Implantação e Relação com o Entorno}

Existem duas maneiras principais de como a arquitetura se posiciona em relação ao entorno: a primeira, considerando o meio como parte da composição, dado essencial e ponto de partida para o projeto. A segunda considera a arquitetura, como objeto autônomo localizado em uma situação ideal, preocupando-se mais com a relação dos espaços entre si do que com o topos ao seu redor.

Uma das principais críticas feitas à arquitetura moderna pelas gerações posteriores é exatamente a questão de rever a relação entre arquitetura e o contexto no qual esta se insere - seja rural ou urbano - e seu diálogo com o entorno imediato. Embora alguns arquitetos do movimento moderno tenham se mostrado sensíveis em relação às características do local, uma parte considerável das obras desse período - mais especificamente, aquelas influenciadas pelo Estilo Internacional - ignoraram este dado.

Pretende-se avaliar a implantação do projeto, sua relação com o entorno, características específicas do terreno, condicionantes topográficas, aproveitamento da ventilação e iluminação natural, relação com o sistema viário existente, aproveitamento das visuais, transição entre espaços abertos e fechados, interferência da paisagem no caráter da edificação, implicações do terreno na disposição e implantação da volumetria básica.

\section{c) Programa de Atividades}

Os espaços modernos deram preferência a ambientes integrados, caracterizados pela interpenetração de áreas, com o intuito de minimizar divisões e compartimentação do espaço. A arquitetura contemporânea, em alguns casos, tira partido da planta livre, mas também, mostra-se sensível às ideias e vontades do cliente, quando este busca uma maior privacidade e distinção entre áreas de serviço e áreas íntimas da residência, optando eventualmente por projetos com setorização mais evidente. 
Será avaliada a solução arquitetônica encontrada para o programa de atividades em questão, a setorização do projeto, organização espacial e esquemas compositivos, relação entre público e privado, a articulação dos espaços e organização dos percursos, áreas de circulação e passagens entre os compartimentos, adequação térmica, lumínica e sonora,

\section{d) Partido Arquitetônico}

Neste tópico objetiva-se identificar a postura do arquiteto em relação à arquitetura em si, suas diretrizes e inspirações para a concepção inicial do projeto, quais problemas foram priorizados e as soluções optadas. A maneira como o arquiteto faz uso do repertório arquitetônico e se posiciona em relação às questões culturais e às tradições - caracterizando a obra como elemento de ruptura ou continuidade. Em resumo, a poética da arquitetura e como ela influi na concepção e resultado da obra como um todo.

\section{e) Sistema Construtivo}

Pretende-se compreender de que forma o arquiteto explora as possibilidades técnicas e estruturais como forma de expressão plástica, a intenção figurativa e o caráter cenográfico do projeto. Identificar o sistema estrutural utilizado, as técnicas construtivas, inovações técnicas, materiais de estrutura e vedação, soluções de revestimento. Analisar-se-á a concepção estrutural e a sua influência na forma arquitetônica.

\section{f) Intenção Plástica}

Avaliar as soluções plásticas e volumétricas, escolha de revestimentos e vedações, tratamento das superfícies, tratamento das aberturas, articulação das massas, diretrizes compositivas, estilísticas e opções de linguagem.

Este roteiro para a análise das residências selecionadas não pretende encerrar o estudo destas obras, tão pouco a discussão sobre a arquitetura 
curitibana contemporânea. O objetivo principal é difundir o conhecimento da arquitetura contemporânea de Curitiba, ainda carente de divulgação e registros, essenciais para o desenvolvimento de uma consciência crítica e evolutiva.

\section{HISTÓRICO DA ARQUITETURA DE CURITIBA}

\subsection{Apresentação}

Curitiba é mais conhecida pelo seu planejamento urbano do que pela sua arquitetura. Até a metade da década de 60, a estrutura da cidade estava baseada no Plano Agache (1941-1943). Em 1964, o então prefeito Ivo Arzua, promoveu a contratação de um novo plano diretor para Curitiba. A concorrência foi vencida pela empresa Serete e teve como coordenador o arquiteto Jorge Wilheim. Após esta etapa, outros arquitetos de Curitiba (por exemplo, Luiz Forte Netto, Jaime Lerner, José Maria Gandolfi, Alfred Willer, Domingos Bongestabs, entre outros) também participariam do desenvolvimento do Plano Preliminar de Urbanismo, transformado em lei no ano de 1966.

Wilheim propôs ainda que fosse criado um órgão que acompanhasse continuamente o processo de planejamento, o que ocorreu com a criação do IPPUC, em 1965.

A partir da metade da década de 70, Curitiba deixou a imagem de cidade pequena para se tornar em um modelo de desenvolvimento planejado. No centro dessa transformação estava um grupo de arquitetos reunidos no então recém-criado curso de arquitetura e urbanismo da UFPR.

Apenas cinco anos depois de ter se graduado com a primeira turma de arquitetos da UFPR, Jaime Lerner assumiu o seu primeiro de dois mandatos como prefeito (1971-74 / 1979-84) e colocou em prática transformações urbanas propostas no Plano Wilheim-IPPUC. A partir de 1995, a equipe de Lerner - formada por arquitetos que ocuparam não somente funções ligadas à arquitetura e planejamento, mas também cargos administrativos de seu governo - assumiu o governo do estado, e, tendo conseguido se reeleger para um segundo mandato, permaneceu no governo até 2002. 
Os projetos urbanísticos implantados na cidade resultaram em uma qualidade de vida superior à maioria das capitais brasileiras e comparável a diversas cidades de países desenvolvidos. Entretanto, pouco se conhece sobre a arquitetura da cidade, em função dos raros estudos e livros dedicados a este assunto. A única exceção provavelmente seja a arquitetura realizada entre os anos 60 e 70, época em que arquitetos de diversas cidades vieram para Curitiba para lecionar no recém-fundado curso de arquitetura da Universidade Federal do Paraná. Esses arquitetos trouxeram novos ares não somente para a arquitetura residencial da cidade - sem dúvida uma época de qualidade singular nos projetos e obras construídos na capital paranaense - mas também, chamaram a atenção vencendo um número considerável de concursos nacionais de projeto.

Situada num planalto pantanoso e pouco acidentado do estado do Paraná, desprovida de grandes atrativos naturais, Curitiba sempre dependeu das suas edificações, ruas, praças e grandes monumentos para alcançar o que a elite da cidade julgava ser a aparência de uma capital. A arquitetura tornou-se a principal maneira de Curitiba afirmar e se convencer de sua própria importância. Inúmeras vezes o poder político da cidade foi entregue a arquitetos e engenheiros, que transformaram a cidade em canteiro de obras, buscando a criação de marcos e símbolos que trouxessem referência e personalidade para a cidade.

Este histórico tem como objetivo esclarecer o papel da arquitetura na afirmação cultural e política de Curitiba entre os anos de 1930 até os anos 90 e fornecer embasamento teórico para o estudo da produção posterior ao ano 2000.

\subsection{A primeira casa modernista em Curitiba}

No Paraná, a primeira obra considerada modernista surgiu na década de 30, com a residência-atelier-escritório de Frederico Kirchgässner. O projeto foi edificado numa ponta de terreno pequena e acidentada, apoiado num declive e adaptando-se ao contorno original do terreno. No andar superior, 
encontrava-se o terraço-mirante e o atelier do arquiteto, acessado por uma pequena escada inserida em um volume semicilíndrico. Com elementos formais até então desconhecidos dos curitibanos - terraços de concretos, brises, janelas nas arestas - foi incompreendida e, pela falta de adjetivo apropriado, foi tachada erroneamente como "futurista".

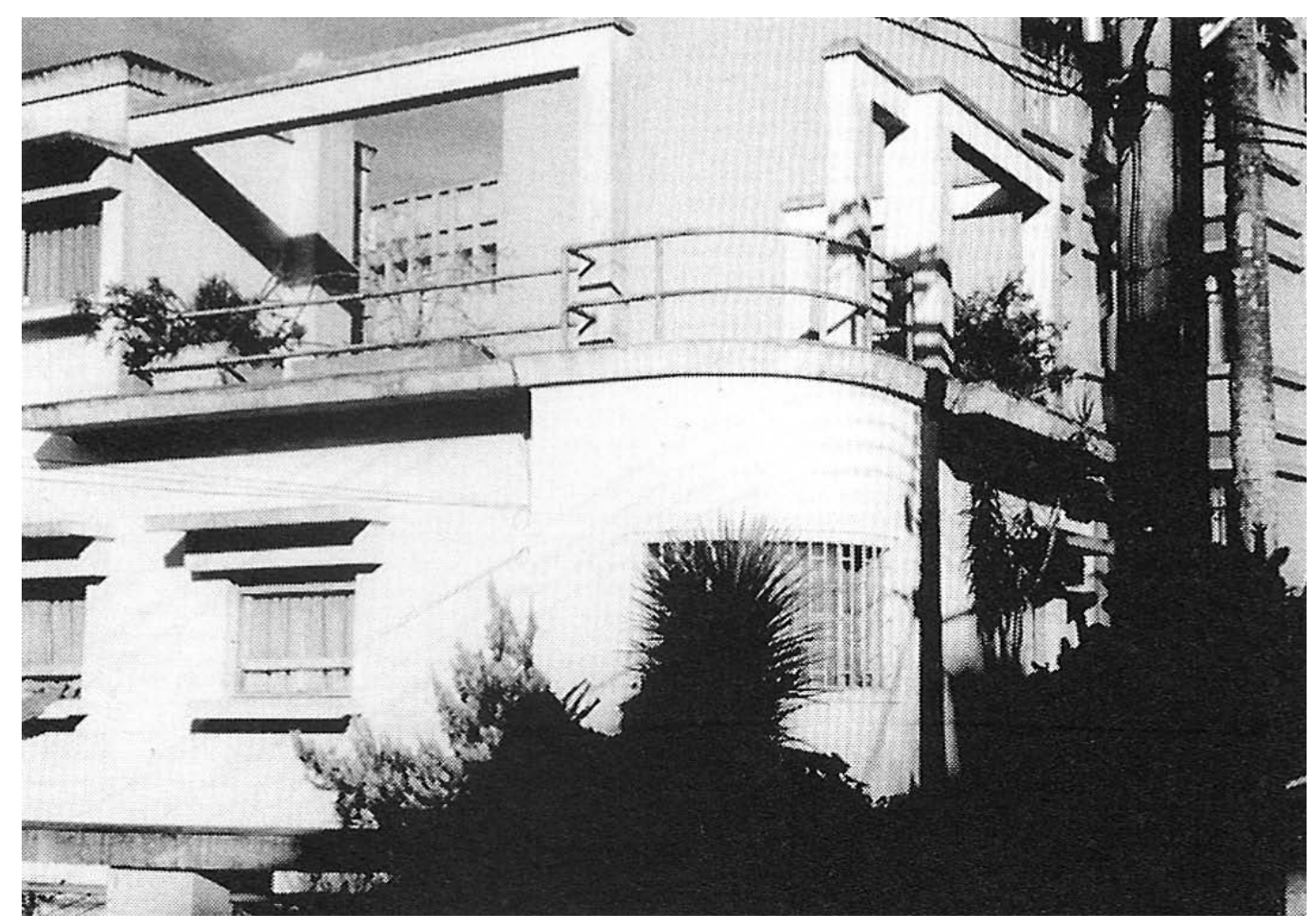

Figura 1 - Residência do Arquiteto Frederico Kirchgässner (1930) 


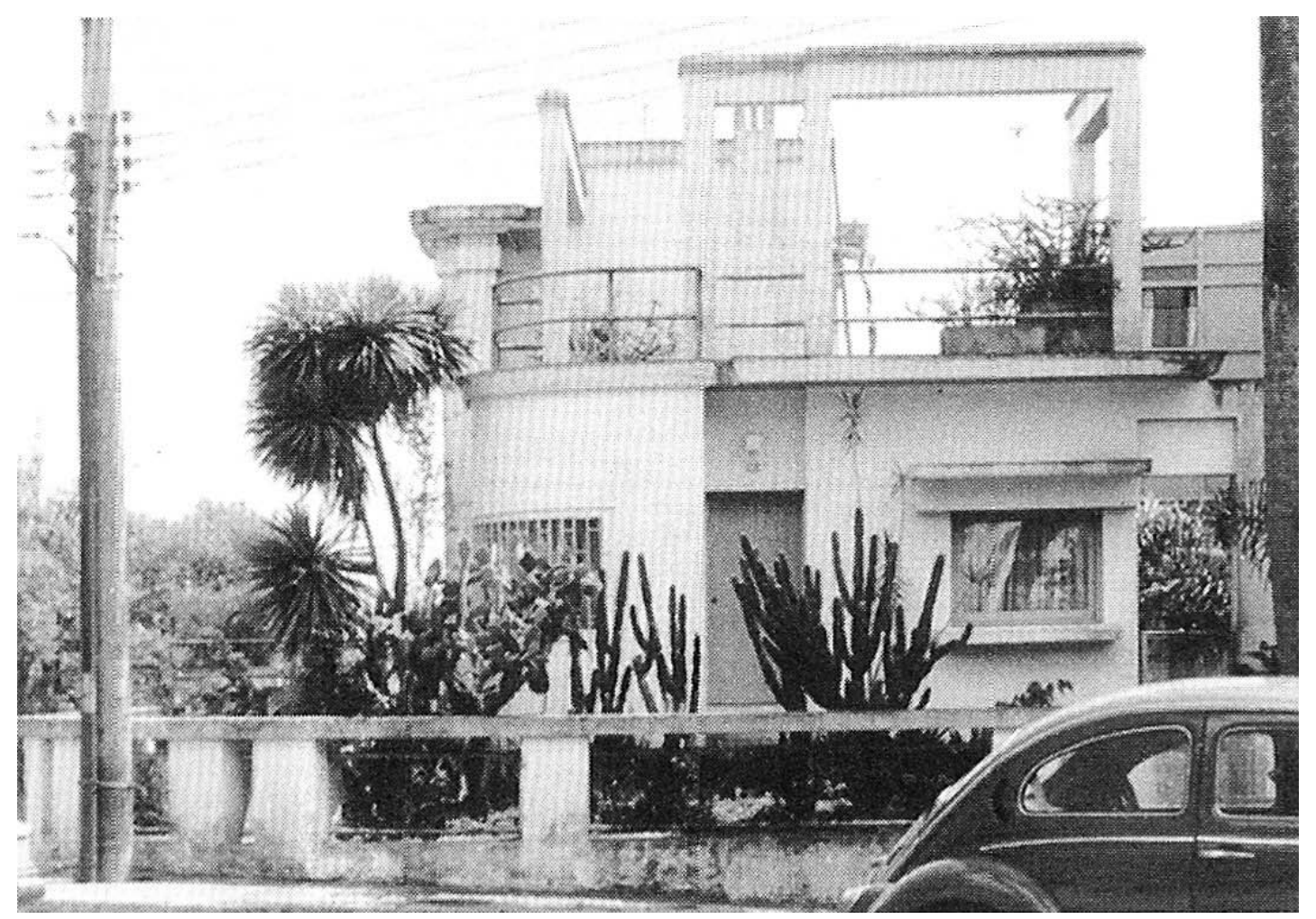

Figura 2 - Residência do Arquiteto Frederico Kirchgässner (1930): rua Jaime Reis

A residência que Kirchgässner projetou para seu irmão, concluída em 1936, foi recebida com a mesma hostilidade. As referências do arquiteto eram desconhecidas para a maioria dos curitibanos: não era paranista, não se assemelhava com obras do Estado, não se parecia com nada significativo, construído entre 1900 e 1930, em Paris, Buenos Aires, Rio de Janeiro ou Berlin. 


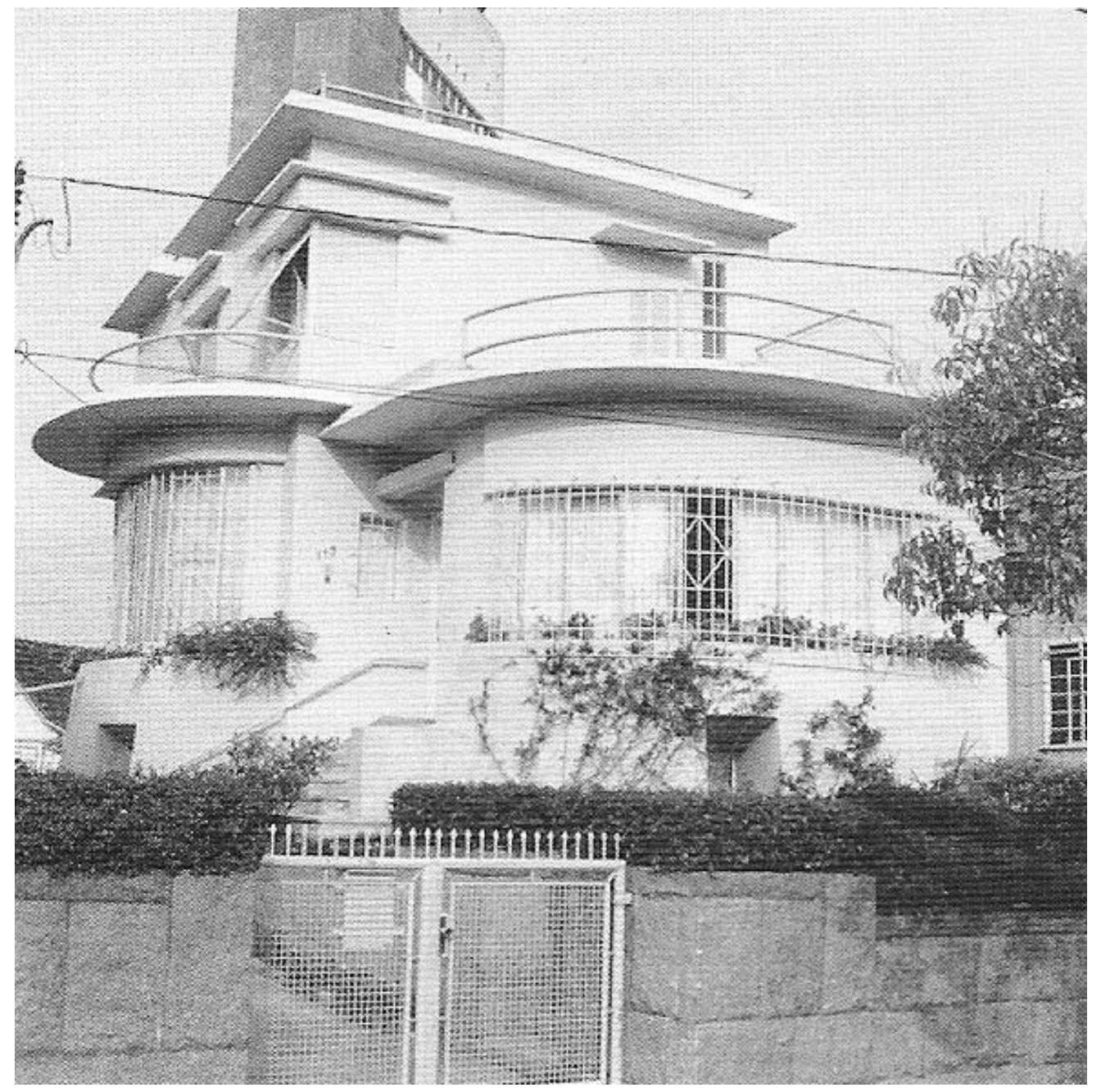

Figura 3 - Residência Bernardo Kirchgässner (1936): vista frontal

Apesar da estreita relação do arquiteto com a Alemanha Kirchgässner nasceu na Alemanha, cursou o primário e secundário em uma escola para imigrantes alemães, em Curitiba, estudou arquitetura através de um curso por correspondência da Deutsche Kunstschule de Berlin - sua arquitetura se assemelhava mais ao construtivismo soviético. A produção arquitetônica mais relevante de Kirchgässner - a casa/atelier do próprio arquiteto e a residência de seu irmão, Bernardo Kirchgässner - pareciam mais influenciadas pelos desenhos teóricos de Konstantin Melnikov ou ao projeto do Palácio do Trabalho, dos irmãos Vesnin, do que com obras dos arquitetos da Neus Bauen alemã. Provavelmente pela estreita relação entre Berlin e União Soviética, durante as primeiras décadas do século $X X$. Contudo, a influência era restrita ao repertório de formas. As adaptações técnicas e formais para a 
realidade curitibana eram claras nos projetos do arquiteto: terraços planos, valorizando as visuais para a Serra do Mar, lajes duplas para controle térmico e impermeabilização.

A arquitetura de Kirchgässner também se distancia de seus contemporâneos brasileiros, trazendo para o país uma referência diferente da que aparecia em São Paulo, com Warchavchik, ou da arquitetura que posteriormente surgiria no Rio de Janeiro. De acordo com Irã Taborda Dudeque, em seu livro Espirais de Madeira:

[...] Kirchgässner é um criador único na arquitetura do Brasil, libertado de seu entorno imediato e dono de um posto, periférico mas inamovível, nas linhas de força da melhor arte dos anos 1920, aquela arte que desprezou fronteira e que seria pisoteada pela bestialidade dos fascismos. ${ }^{17}$

\subsection{A influência de Le Corbusier e das vanguardas europeias}

Durante a década de 40 , observa-se que a arquitetura considerada moderna dividia-se em duas tendências: o art déco e a arquitetura brasileira, influenciada por Le Corbusier. Entretanto, particularmente, no Rio de Janeiro, essa separação não era tão evidente quanto depois pareceria ser: as duas linhas de projeto eram consideradas modernas e complementares.

A grande diferença é que a opção pela arquitetura influenciada por Le Corbusier estava limitada a uma pequena elite carioca, enquanto o art déco era a tendência predominante no resto do país.

Os ecos do Movimento Moderno só chegariam ao Paraná no final desta década, quando Oscar Niemeyer e Lucio Costa obtiveram reconhecimento internacional, após a construção do Ministério da Educação, no Rio de Janeiro, e do Pavilhão de Nova York, mas levariam quase uma década para encontrar defensores em Curitiba.

\footnotetext{
${ }^{17}$ DUDEQUE, Irã José Taborda. Espirais de madeira: uma história da arquitetura de Curitiba. São Paulo, Studio Nobel, 2001.
} 
Se no início dos anos 40, Curitiba e o Paraná encontravam-se numa crise econômica que se arrastava desde 1930, depois de 1946, com o fim da Segunda Guerra e significativa melhoria da condição econômica do país, Curitiba entrou em um período de euforia construtiva.

A nova fase da arquitetura de Curitiba, que culminaria com a afirmação de cidade, nos anos 50, foi de certa forma influenciada pelos problemas urbanísticos da cidade. Se até à década de 40, Curitiba havia crescido livremente como uma cidade colonial, a partir desta data o plano urbanístico da cidade seria revisado e requalificado de acordo com as diretrizes do francês Donat-Alfred Agache.

Fazia parte dessa equipe o estudante de engenharia Ayrton "Lolô" Cornelsen. Orientado pelo arquiteto francês a se dedicar à arquitetura e influenciado pelo livro Le Corbusier et Pierre Jeanneret (Euvre Complete de 1910-1929), que ganhou de presente de Agache, Lolô Cornelsen tornar-se-ia na década seguinte, um dos personagens mais importantes e revolucionários da arquitetura de Curitiba.

Secretário de transportes do governo do Paraná, a partir de 1956, Lolô participou de projetos importantes em todo país e no exterior. Comandou a equipe que projetou o plano urbano de Puero Strossner (Paraguai); foi representante do Brasil no $V$ Congresso de Arquitetura e Urbanismo, na União Soviética; idealizou, construiu e foi proprietário do autódromo de Jacarepaguá, no Rio de Janeiro; projetou o Estádio do Mineirão, em Belo Horizonte. O mais notável de sua obra é que diversas soluções técnicas surgiram simultaneamente em relação à arquitetura desenvolvida em São Paulo e Rio de Janeiro - e ainda assim o arquiteto foi praticamente ignorado em Curitiba.

As primeiras residências projetadas por Lolô Cornelsen apareceram na segunda metade da década de 40 e eram visivelmente influenciadas pela arquitetura de Le Corbusier. Na residência Nelson Justos, projetada em 1945, a solução em planta desenvolvia-se ao redor de um átrio central que, com o a utilização de persianas, integrava ou separava os outros cômodos desse ambiente. Na mesma época, o arquiteto João Batista Vilanova Artigas projetou as residências de seus irmãos Joel e Giocondo. Numa cidade provinciana e 
ainda desconfiada da "nova arquitetura", as propostas desses arquitetos foram recebidas com espanto.

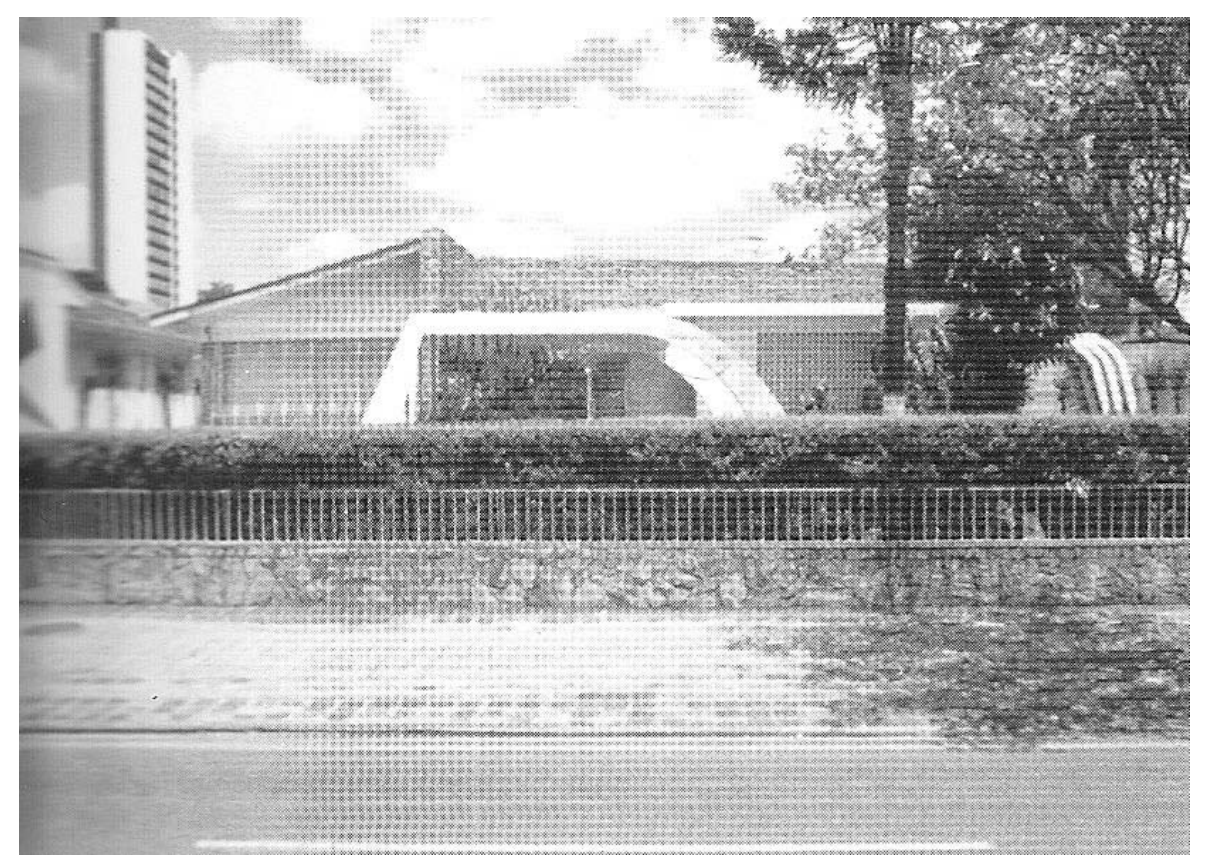

Figura 4 - Residência Nelson Justus (1945): vista frontal

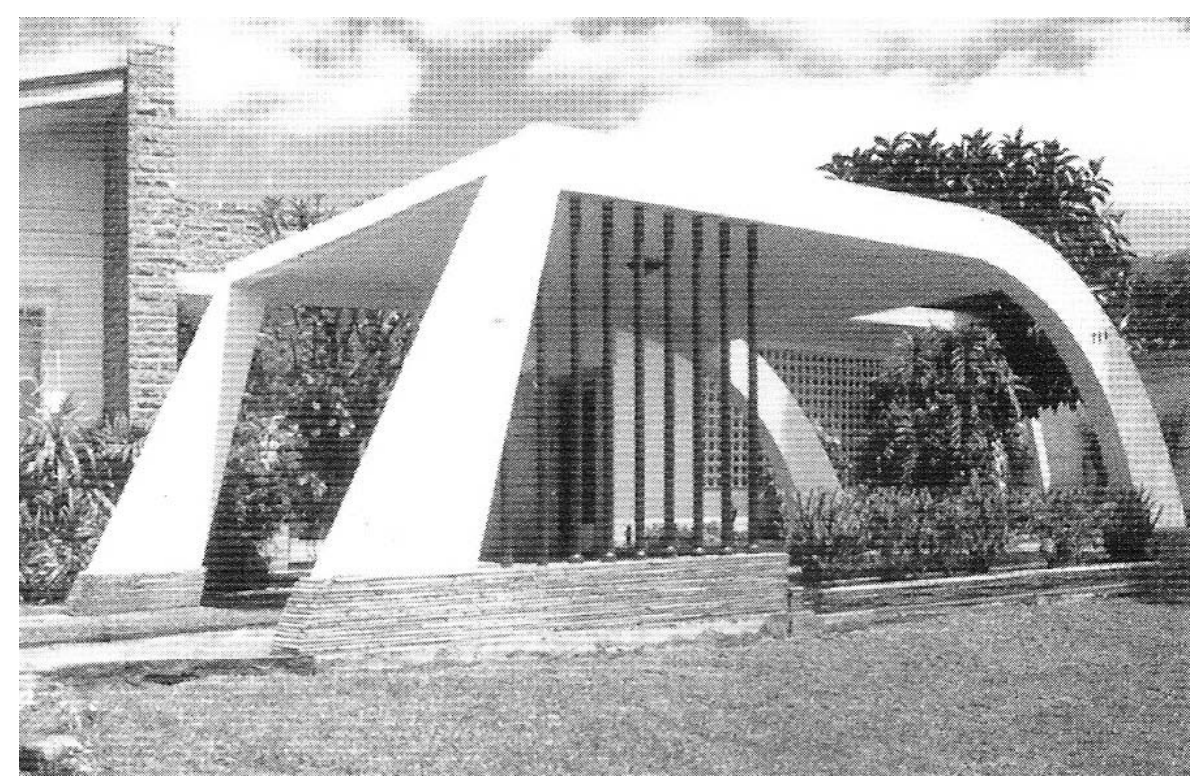

Figura 5 - Residência Nelson Justus (1945): cobertura de automóveis

Foi no projeto de sua própria residência que Lolô garantiu um avanço significativo na arquitetura de curitibana. Além do posicionamento da casa, no fundo do lote, o arquiteto apresentou uma novidade para a arquitetura da 
cidade: os pilotis corbusianos. Desta forma, a residência desprendia-se do chão e os ambientes do térreo abriam-se para o jardim, integrando os ambientes à natureza. O terraço curvo do pavimento superior - um dos poucos elementos da arquitetura de Curitiba, criado a partir de curvas livres - reforçava a sensação de integração com o entorno. Esta residência foi totalmente demolida, em 1999.

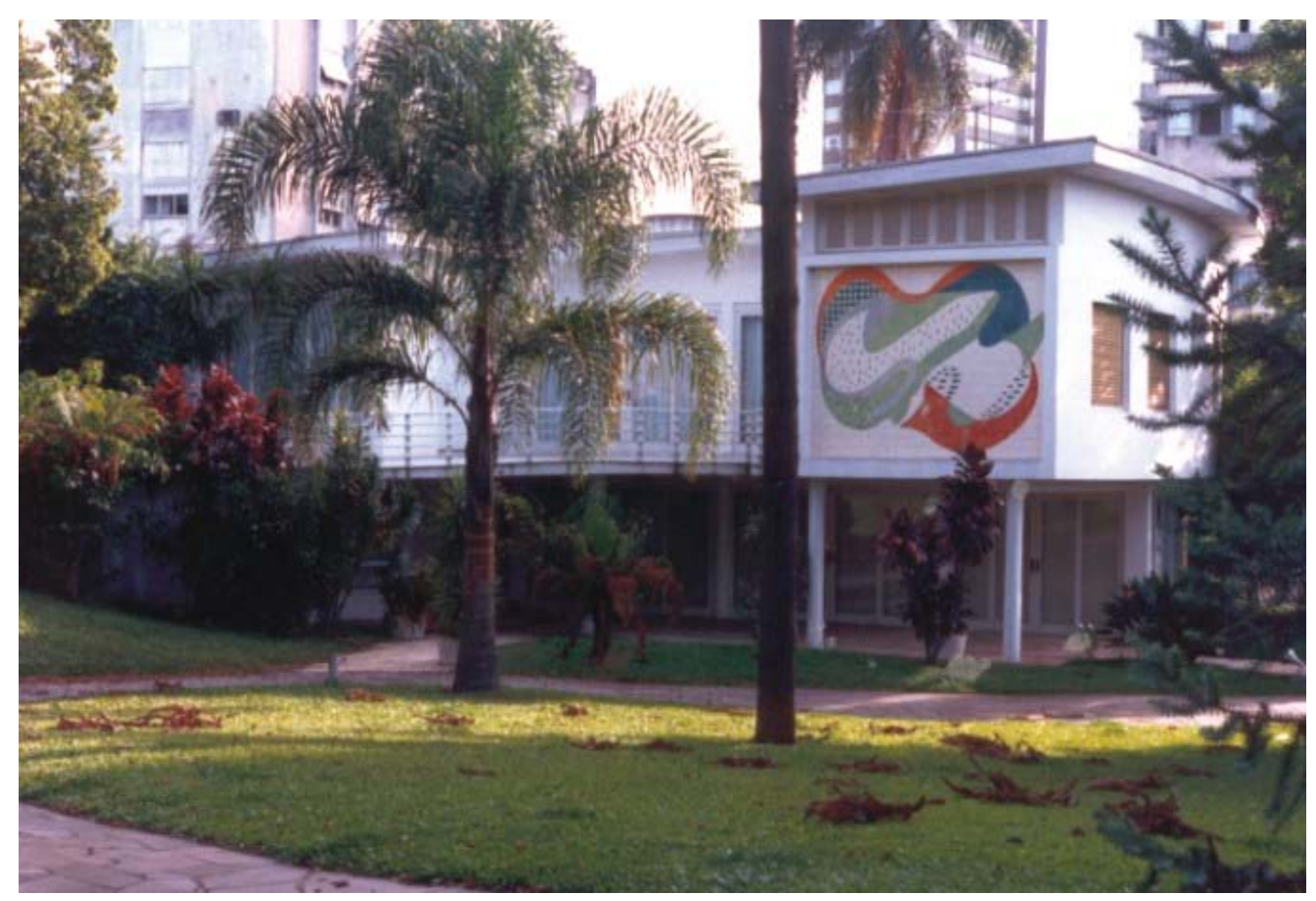

Figura 6 - Residência do Arquiteto Lolô Cornelsen (1949)

Em 1948, um debate acerca do resultado do concurso para o projeto do Teatro Oficial do Estado marcou o início do reconhecimento da arquitetura influenciada por Le Corbusier, na cidade. O então diretor da Escola de Música e Belas Artes do Paraná, Fernando Corrêa de Azevedo, publicou um texto na Gazeta do Povo (até hoje um dos principais jornais do estado) questionando o resultado do concurso - do qual ele fazia parte do júri.

Correa de Azevedo defendia que o primeiro colocado deveria receber o prêmio, mas que o projeto a ser construído deveria ser o terceiro colocado. $O$ projeto defendido por Correa de Azevedo era do recém-formado arquiteto Rubens Meister, influenciado pelo racionalismo alemão, particularmente, por 
obras de Mies van der Rohe e Walter Gropius. De acordo com Irã Dudeque, Correa de Azevedo alegava que "um projeto art déco poderia até agradar o entorno provinciano, mas Curitiba perderia a chance de possuir uma obra que repercutisse além de suas próprias fronteiras.” (DUDEQUE, 2001, p. 139). Defendia ainda que o edifício devia ser retrato de uma época, deixando claro o período da construção e as características desse período para gerações futuras.

Correa de Azevedo obteria êxito no seu manifesto, alguns anos depois, durante o governo de Munhoz da Rocha. O então governador anulou 0 concurso e determinou a construção do projeto de Rubens Meister em novo local: o teatro não seria construído na Praça Rui Barbosa, e sim, na Praça Santos Andrade. Junto com a mudança do local veio a mudança do nome: a maior sala de espetáculos da capital paranaense, projetada para abrigar mais de 2500 espectadores se denominaria Teatro Guaíra.

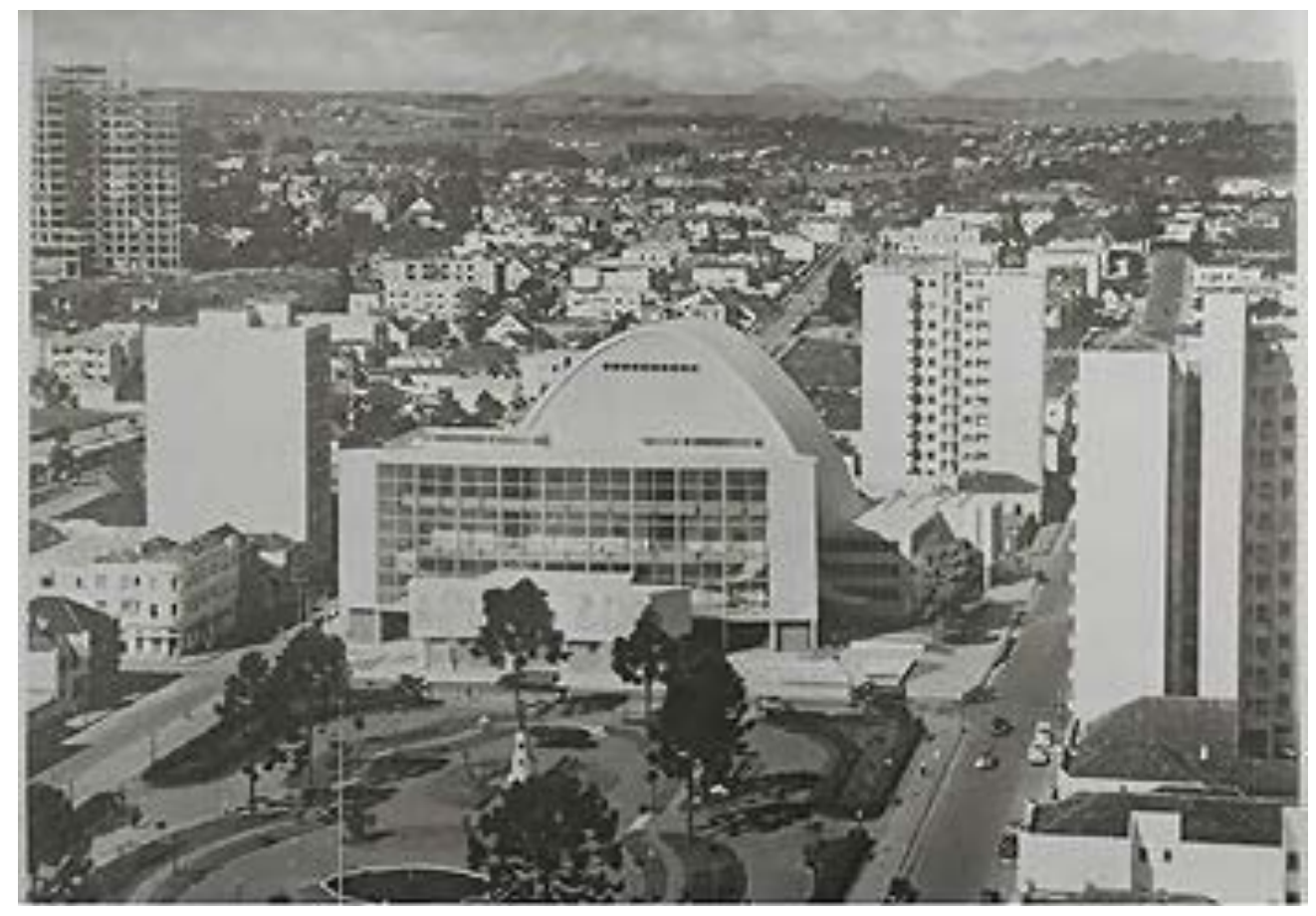

Figura 7 - Teatro Guaíra (1954) 


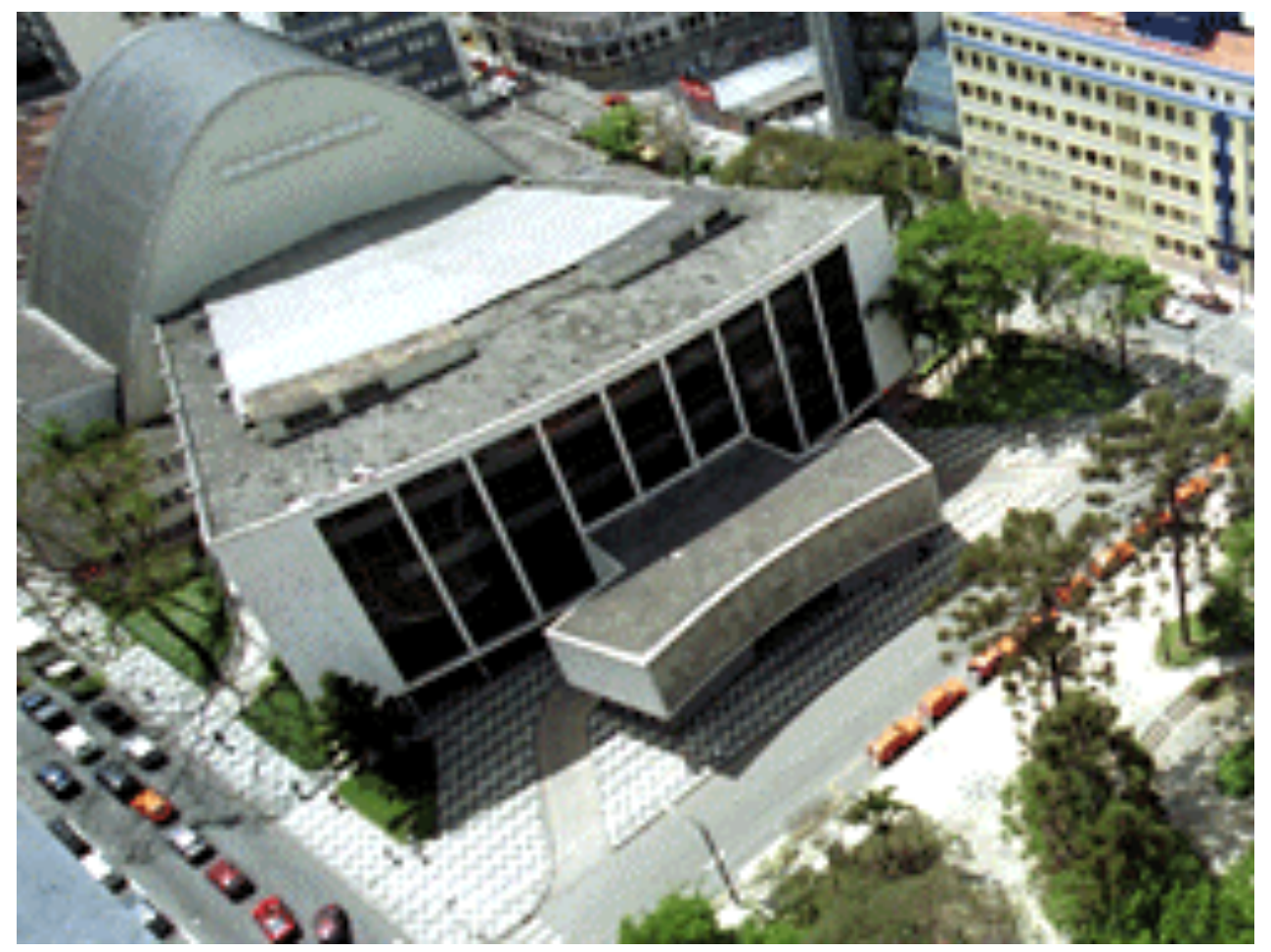

Figura 8 - Teatro Guaíra (1954): vista aérea

\subsection{Expansão cafeeira e o governo Munhoz da Rocha}

Grandes áreas de terra do norte e sudoeste do Paraná foram ocupadas pela expansão da indústria cafeeira, nos anos 50 . O estado tornou-se um dos principais centros de exportação do país e a lucratividade com impostos cresceu consideravelmente. Esse período coincidiu com o Centenário de Emancipação Política do Paraná e com o governo de Bento Munhoz da Rocha.

A principal proposta de governo de Munhoz da Rocha era a criação de marcos que assinalassem o centenário paranaense. Para isso, criou a Comissão Especial das Obras do Centenário (CEOC), com o objetivo de unificar o estado, usando a arquitetura corbusiana como expressão do progresso e imortalizar a importância política e econômica do Paraná desse período. Além do Teatro Guaíra, citado no capítulo anterior, o governador determinou a construção da Biblioteca Pública, que teria o papel de centralizar a cultura produzida no estado.

No plano urbanístico, o objetivo de Munhoz da Rocha era interligar a capital do estado às regiões Norte e Sudoeste. Nesse aspecto, é importante 
ressaltar que o polo da expansão cafeeira - particularmente a cidade de Londrina, que ficou então conhecida como Eldorado brasileiro - tinha pouca ou nenhuma identificação com Curitiba. Dois terços dos fazendeiros, no norte do estado, eram de São Paulo ou filhos de famílias Paulistas. Em termos geográficos, Londrina encontrava-se mais próxima da cidade de São Paulo do que de Curitiba. A ligação viária entre Londrina e São Paulo - fosse através da principal ferrovia, que cruzava o norte do Paraná, ou através da rodovia pavimentada em praticamente toda a sua extensão - era muito mais fácil do que o sinuoso caminho de ferro, que ligava Londrina a Curitiba, ou a precária estrada do Cerne.

Além da criação e melhoria da malha viária, interligando as diversas regiões do estado com a capital, Munhoz da Rocha defendeu a ideia, apresentada no plano urbanístico de Agache, da criação do Centro Cívico conjunto arquitetônico que centralizaria os poderes Executivo, Legislativo e Judiciário do estado em um único lugar.

O Centro Cívico de Curitiba buscava, antes de qualquer coisa, o reconhecimento da importância do Paraná como um dos principais centros econômicos e políticos do país. Para uma obra com tamanha importância, optou-se por chamar arquitetos do "centro político e arquitetônico do país" - o Rio de Janeiro. Foi criada uma equipe formada pelos cariocas Olavo Redig de Campos, Flávio Regis e Sérgio Rodrigues, coordenada pelo arquiteto David Xavier de Azambuja - nascido no Paraná e professor da disciplina Planejamento de Obras, no Mackenzie.

As obras do Centro Cívico foram diretamente responsáveis pela atualização da indústria da construção civil de Curitiba, mas pouco ou nada fizeram pela integração do Estado. O alto custo das obras comprometeu todo o orçamento do governo, impossibilitando a construção das estradas, que ligariam Curitiba ao norte e sudoeste. Apesar do cultivo do café aumentar em progressão geométrica, o acúmulo de riquezas no estado, em 1955, uma mudança climática comprometeu $75 \%$ da safra cafeeira do estado. Como resultado, a arrecadação de impostos referentes à exportação do café também 
caiu - e a redução drástica da verba prevista para a finalização dos projetos em andamento fez com que as obras fossem paralisadas.

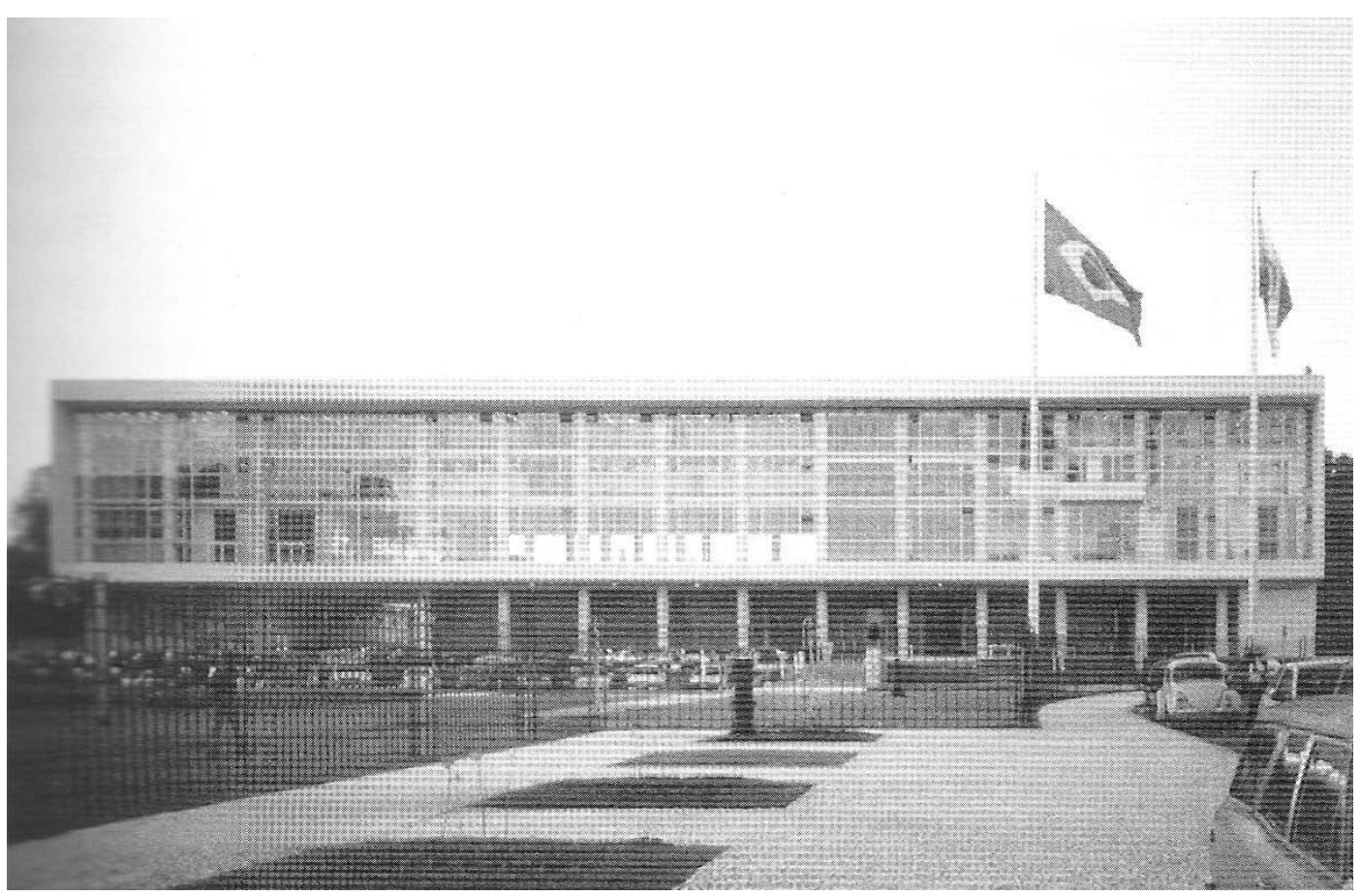

Figura 9 - Centro Cívico, Palácio Iguaçu (1953): frente

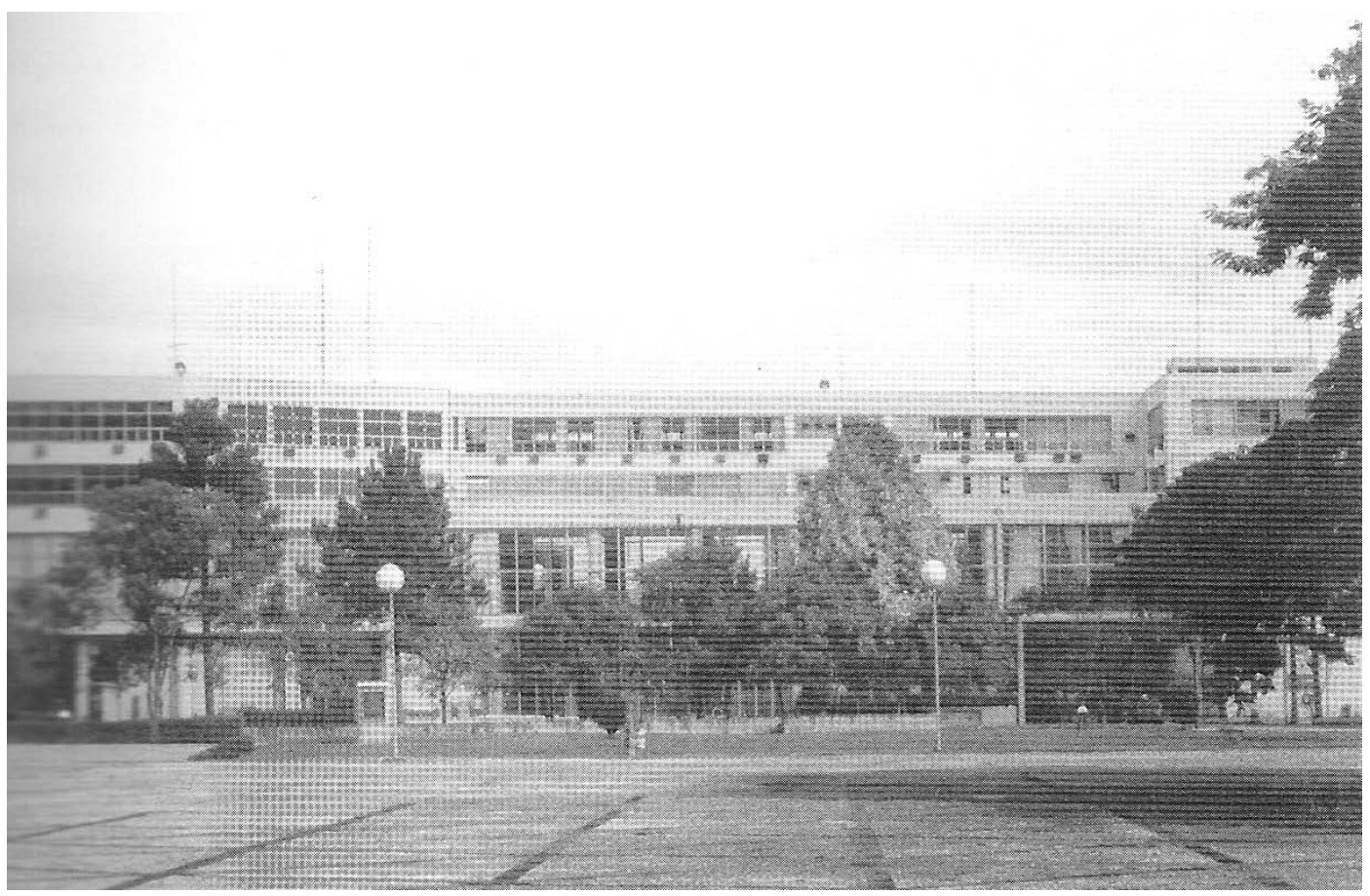

Figura 10 - Centro Cívico, Palácio Iguaçu (1953): fundos 


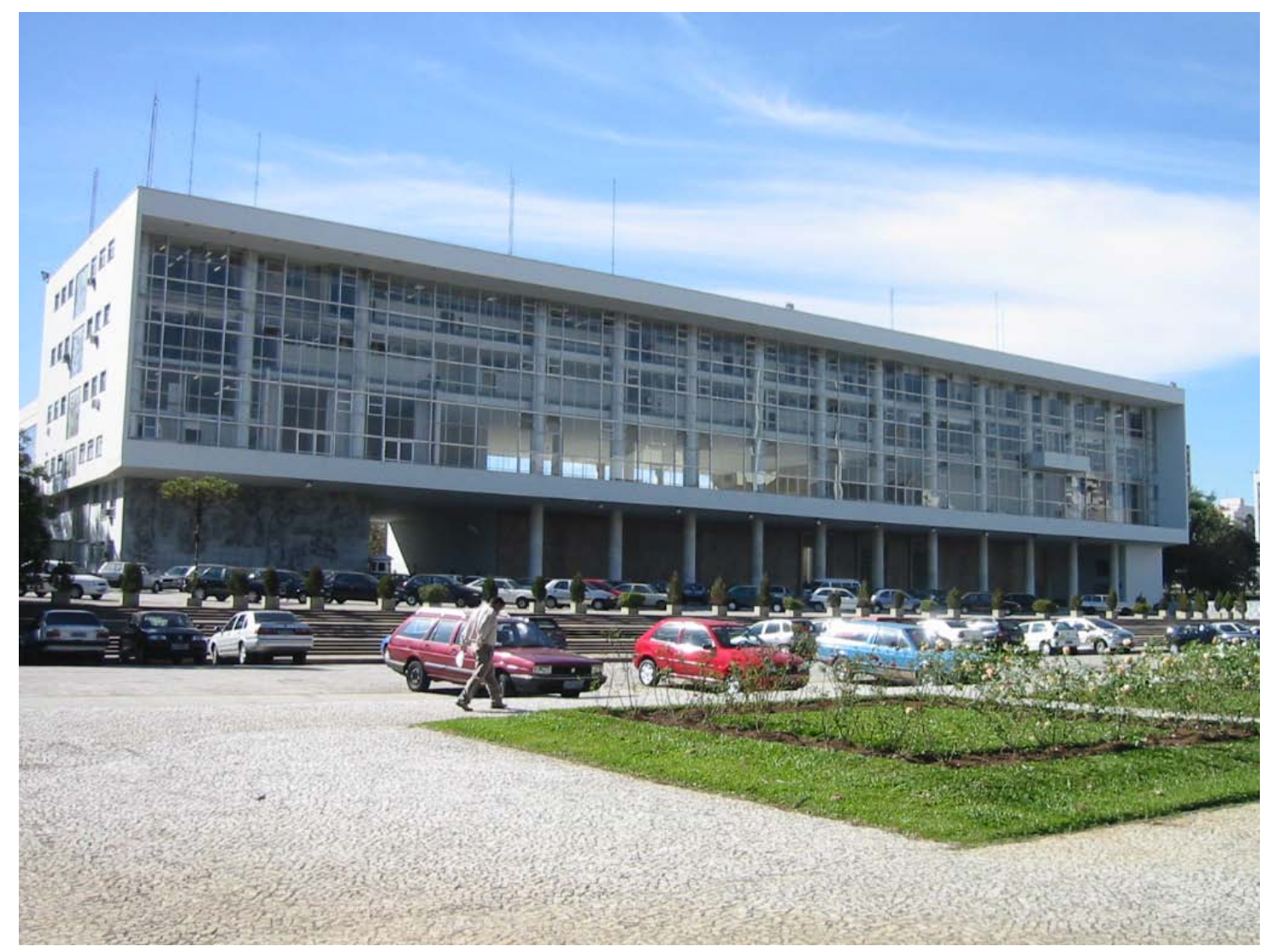

Figura 11 - Centro Cívico, Palácio Iguaçu (1953)

Apesar do projeto para o Centro Cívico de Curitiba não ter sido concluído de acordo com o previsto, a influencia da arquitetura modernista em obras de grande porte em Curitiba alterou a percepção de projeto arquitetônico dos curitibanos. Sob a alcunha de "estilo funcional", móveis de linhas retas da fábrica Móveis Cimo começaram a invadir as casas da burguesia curitibana e residências de novo aspecto, construídas com o auxílio de financiamentos tornaram-se cada vez mais comuns nos bairros da cidade. A cidade, finalmente, começava a aceitar as novas formas da arquitetura modernista.

Essa mudança de visão permitiu que em 1953, Artigas projetasse a residência João Luís Bettega e apresentasse à cidade o estágio de desenvolvimento intelectual, técnico e ideológico da arquitetura de São Paulo. O projeto consistia em um volume único, de comprimento quatro vezes maior do que a largura, encostada do lado direito do lote. Esta implantação da residência permitiu que todos os ambientes ficassem voltados para noroeste, fachada com insolação abundante no inverno de Curitiba, e protegida do sol 
durante os meses mais quentes. As fachadas foram tratadas de acordo com o pensamento que Artigas desenvolveu nos anos 50 - as elevações eram tratadas de forma mais ou menos igual, buscando a unidade de projeto, sem que houvesse uma valorização específica da fachada frontal. No interior, a sala com pé direito duplo articulava os dois pavimentos da residência: no inferior, sala de jantar e cozinha; no superior, os quartos. Outra característica inédita da obra de Artigas, em relação à arquitetura até então projetada em Curitiba, era a riqueza de percursos da residência. A partir do portão de acesso, duas rampas levavam à porta de entrada da residência, na lateral direita. A partir deste ponto, se poderia acessar a residência através do hall, ir para a área de serviço, nos fundos da residência, ou dirigir-se para o terraço, sobre a garagem. A partir deste terraço, uma escada levava, primeiramente, até à sala e, num segundo lance, até ao estúdio. Irã Dudeque, em seu livro Espirais de Madeira, escreveu sobre esse projeto de Artigas:

\footnotetext{
A maestria na concepção de percursos só pode ser compreendida através da experiência de caminhar através dos passeios arquiteturais criados por Artigas. $\mathrm{Na}$ arquitetura residencial de Curitiba, Artigas é imbatível neste quesito, o único concorrente possível da Residência Bettega é a Residência Niclevicz, que seria projetada quase um quarto de século depois, em 1975, pelo próprio Artigas $^{18}$
}

\footnotetext{
${ }^{18}$ DUDEQUE, Irã José Taborda. Espirais de madeira: uma história da arquitetura de Curitiba. São Paulo, Studio Nobel, 2001.
} 


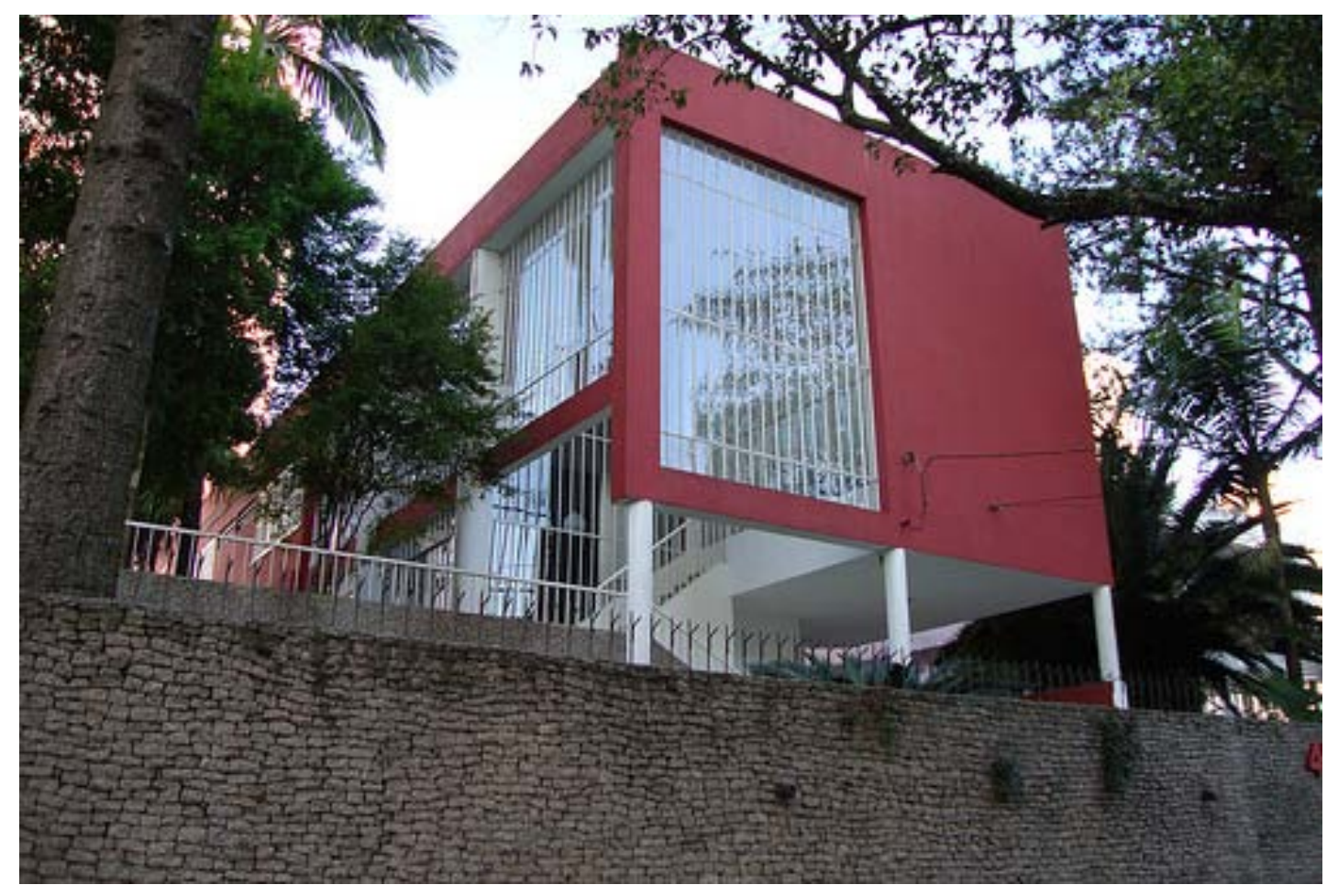

Figura 12 - Residência João Luiz Bettega (1953)

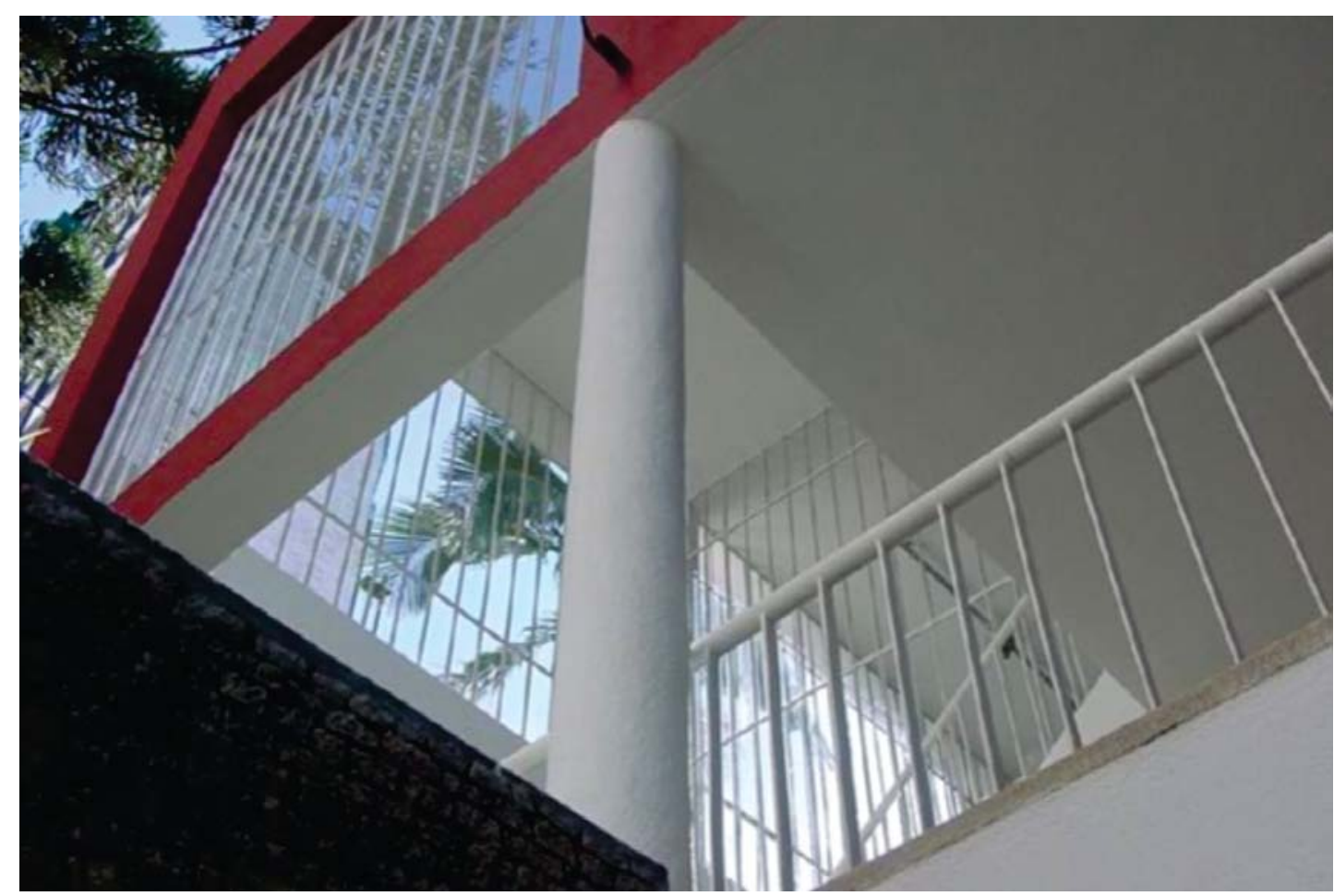

Figura 13 - Residência João Luiz Bettega (1953): terraço sobre a garagem 


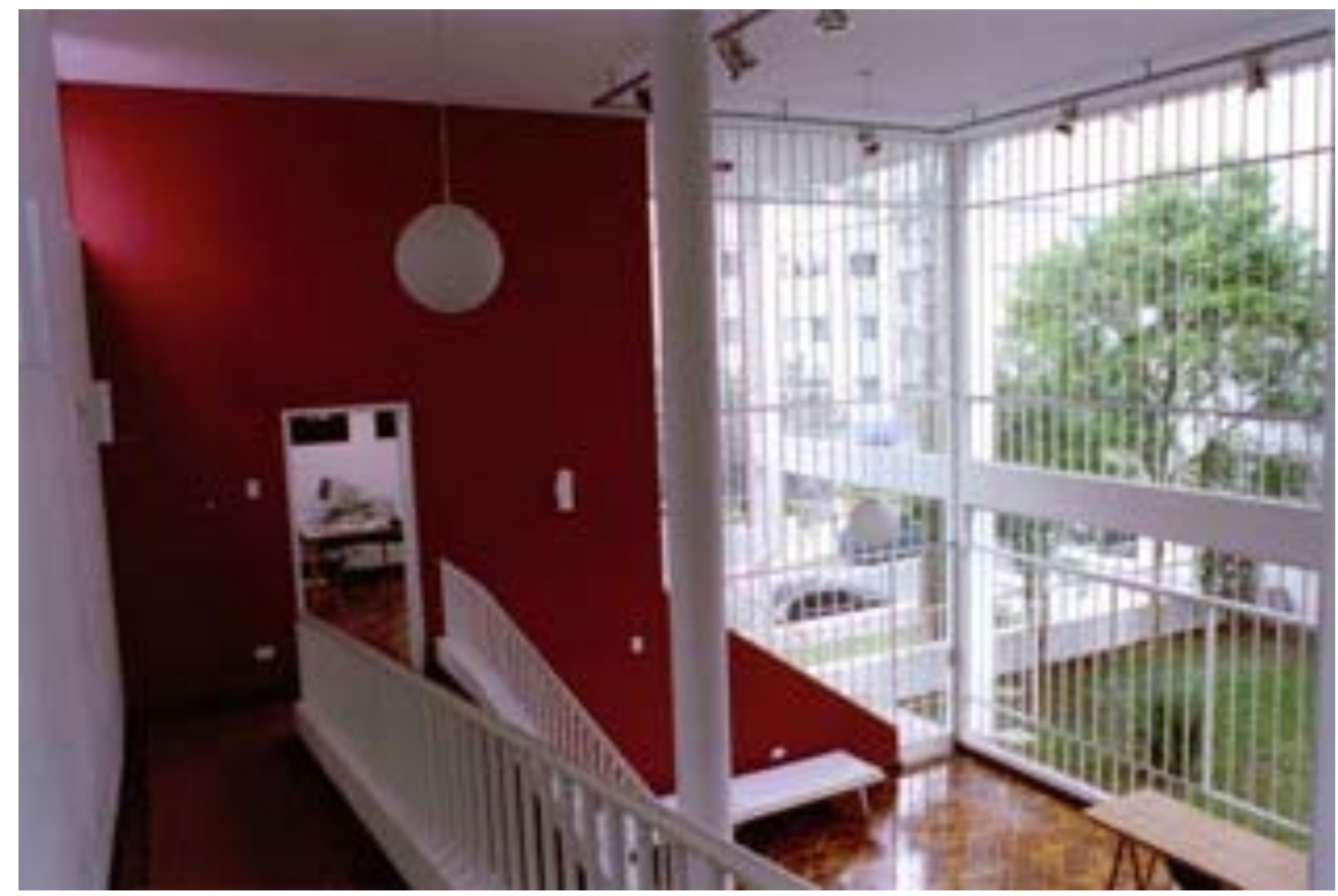

Figura 14 - Residência João Luiz Bettega (1953): interior

Além deste projeto de Artigas, outras residências modernistas, projetadas por Lolô Cornelsen e Elgson Ribeiro Gomes, entre outros, foram construídas em Curitiba nessa época, mas sem causar tanto espanto à população, que já estava familiarizada com as linhas e tendências das obras do Centro Cívico.

\subsection{Década de 60 e a influência da arquitetura paulista}

$\mathrm{Na}$ segunda metade dos anos 50, o reconhecimento nacional e internacional da arquitetura brasileira estava estabelecido. Apesar da importância da arquitetura e dos arquitetos cariocas nesse processo, a influência arquitetônica no Paraná era a arquitetura paulista.

A influência carioca chegou ao ápice em meados dos anos 50, mas não durou muito tempo. Isso porque os arquitetos paranaenses se deram conta de que, ao incluir em seu discurso, itens como "as montanhas do meu país, o curso sinuoso dos rios, as ondas do mar", o "país" ao qual se referia à escola carioca era, na verdade, o Rio de Janeiro. E essas referências pouco ou nada 
tinham a ver com a realidade de Curitiba. A falta de identificação com o discurso carioca, aliado à influência dos arquitetos paulistas, que vieram para Curitiba lecionar no recém-criado Curso de Arquitetura da UFPR, fez com que a cidade se distanciasse da arquitetura do Rio de Janeiro e abraçasse a influência paulista.

A catástrofe climática de 1955, que causou a devastação da economia do Paraná, resultou na criação da PLADEP (Comissão de Planejamento e Desenvolvimento econômico do Estado do Paraná). A PLADEP foi responsável por estudos e levantamentos sobre o estado do Paraná e suas potencialidades. O governo criou, então, a FDE (Fundo de Desenvolvimento Econômico), com objetivo de viabilizar economicamente projetos de desenvolvimento do estado com base nesses estudos. Foi criado ainda um órgão responsável pela administração da FDE, a CODEPAR (Companhia de Desenvolvimento Econômico do Paraná). Os projetos seriam financiados pela FDE, a juros baixos, e incentivariam o Paraná produzir de forma autônoma ao invés de importar matéria prima. Um dos itens incentivados com juros baixíssimos era o cimento. Os reflexos na arquitetura da cidade foram praticamente imediatos.

A influência da CODEPAR na arquitetura curitibana não aconteceu apenas pelo incentivo financeiro à produção de cimento no Paraná. Um dos focos da CODEPAR era o planejamento urbano. A CODEPAR arcava com $90 \%$ dos custos da criação de planos diretores para as cidades do estado, deixando apenas $10 \%$ do encargo para os governos municipais.

Um dos destaques desse incentivo foi o Plano Preliminar de Curitiba, principal diretriz de transformação da cidade, a partir da segunda metade da década de 60. Para implantar esse plano diretor, foi criado o IPPUC (Instituto de Pesquisa e Planejamento Urbano de Curitiba). Em poucos anos, o IPPUC foi considerado pela Fundação Getúlio Vargas como modelo ideal para o desenvolvimento urbano das cidades brasileiras.

A criação de todos esses órgãos ligados ao planejamento $\mathrm{e}$ desenvolvimento do Estado, trouxe a necessidade de formação de profissionais qualificados para o planejamento urbano, regional e de obras. Com este objetivo, foi fundado em 1961 o Curso de Arquitetura e Urbanismo da UFPR. 
Arquitetos de diversos estados, particularmente de São Paulo, foram convidados a lecionar nesse curso, resultando numa invasão de arquitetos em Curitiba. Esta invasão de arquitetos, associada às iniciativas da CODEPAR e acontecimentos econômicos, políticos e culturais do período, resultariam na transformação da arquitetura da cidade.

Esses arquitetos, recém-chegados em Curitiba, marcariam a arquitetura da cidade com edifícios e vitórias em concursos nacionais (particularmente edifício sede da Petrobrás no Rio de Janeiro, projeto da equipe de arquitetos, liderada por Roberto Luís Gandolfi, Luiz Forte Netto e José Sanchotene). Mas, devido à grande demanda e liberdade criativa, que os arquitetos tinham em projetos de casas unifamiliares, a principal transformação da arquitetura da cidade ocorreria na tipologia residencial.

Se durante os anos 50 as aspirações dos arquitetos-engenheiros de Curitiba era a simplicidade formal, para os recém-chegados arquitetos paulistas a intenção era oposta: volumes em atrito, estruturas expostas, plasticidade dos materiais. Na década de 50 , a principal preocupação dos projetos residenciais era a planta: quartos voltados para a face norte, circulações proporcionando a independência entre áreas de serviço, íntima e social da residência. Já nos anos 60 , os arquitetos projetavam os espaços a partir de um pensamento tridimensional, com mezaninos, desníveis e meios-níveis, buscando a interação entre plantas e cortes do projeto. Esses projetos, elaborados em três dimensões, resultariam em espaços inéditos entre as construções até então realizadas na cidade.

\subsection{Os anos $\mathbf{7 0}$}

Nos anos 70, boa parte dos recursos do milagre brasileiro foi direcionada para a construção civil, possibilitando aos arquitetos experimentações inéditas. Primava-se pelos grandes espaços integrados, pelas superfícies ásperas, pelos virtuosismos estruturais e variedade de materiais. Em Curitiba, nesse período, a influência da arquitetura paulista era clara. Além dos profissionais paulistas, estabelecidos em Curitiba, havia aqueles que se 
graduaram sob a influência paulista: estudantes da UFPR que passaram boa parte do curso admirando revistas com obras produzidas em São Paulo.

$\mathrm{Na}$ arquitetura residencial, destacaram-se algumas casas influenciadas pela abstração da arquitetura paulista, associada a elementos tradicionais de Curitiba e símbolos paranistas. Nesse período, observa-se uma forte influência de Artigas, principalmente, em relação à integração entre residência e lote.

No projeto de sua residência, a arquiteta Maria Nadir de Carvalho projetou um volume inteiramente em concreto aparente, sem qualquer acabamento depois de desenformado. A influência de Artigas era evidente na empena parcialmente cega, voltada para rua e na diluição das fronteiras entre cômodos. Ao término da obra, o paisagismo, inicialmente, estabeleceu uma relação entre a obra e a vegetação, para posteriormente tomar conta da fachada e encobrir o exterior da construção.

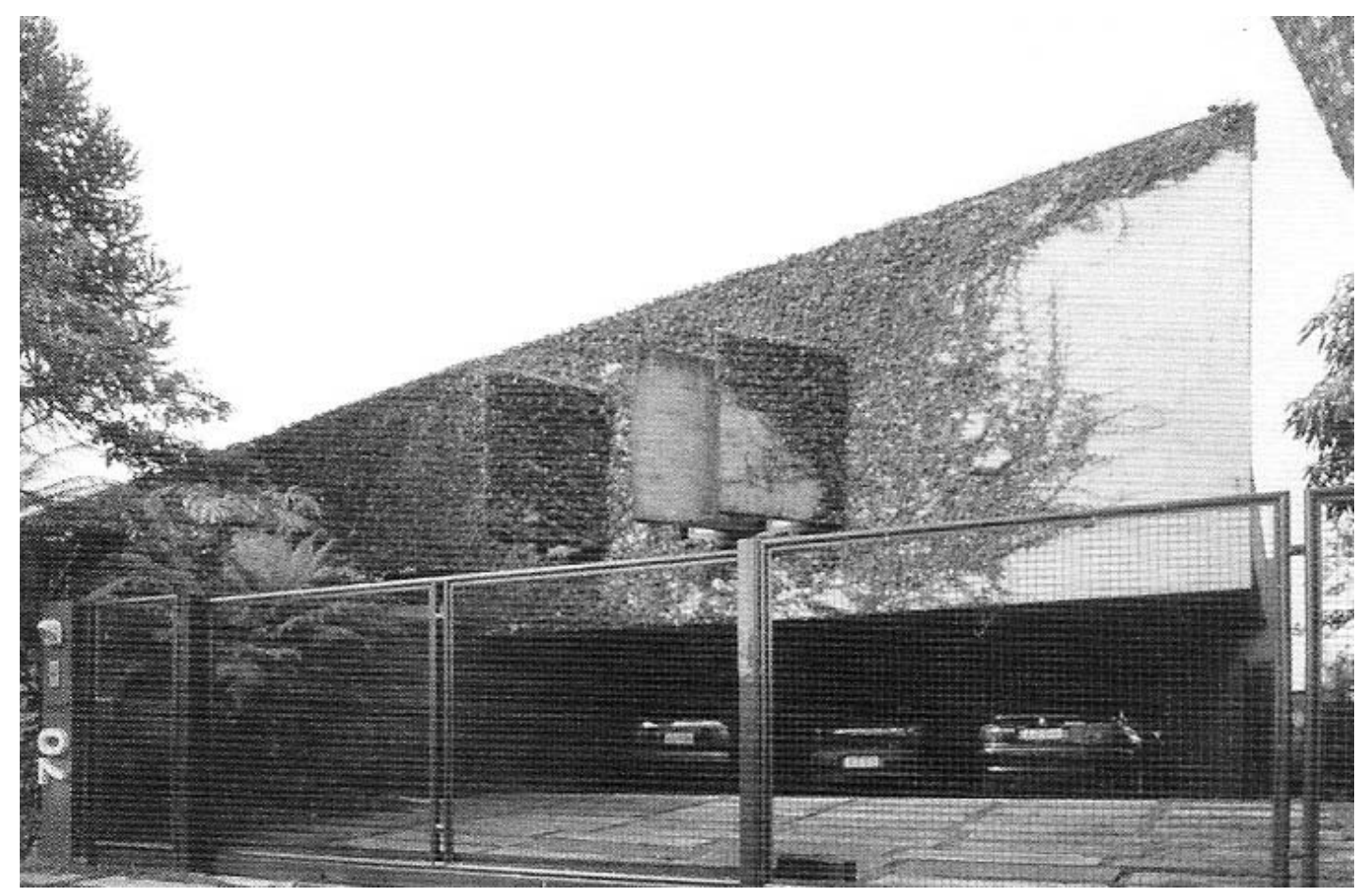

Figura 15 - Residência da Arquiteta Maria Nadir de Carvalho (1975): frente 


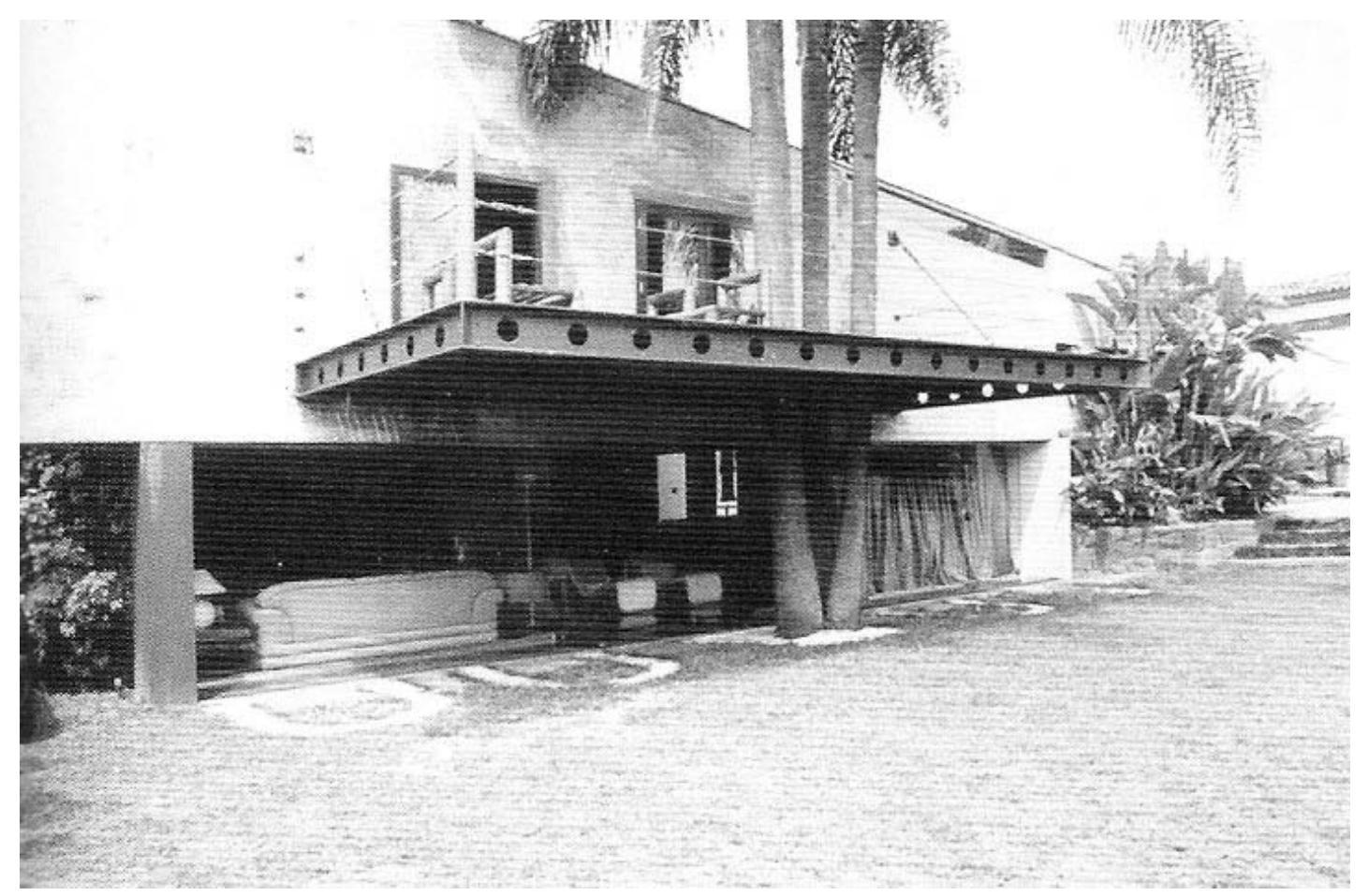

Figura 16 - Residência da Arquiteta Maria Nadir de Carvalho (1975)

A influência de Artigas pode ainda ser observada na Residência José Tadeu de Araújo, dos arquitetos Carlos Emiliano França e Sérgio Roberto Parada. Os arquitetos posicionaram a residência, junto a uma das laterais do lote, liberando um jardim lateral. Com exceção da área de serviço, todos os ambientes estavam integrados com o jardim lateral - repetindo a solução utilizada por Artigas, na Residência Bettega. 


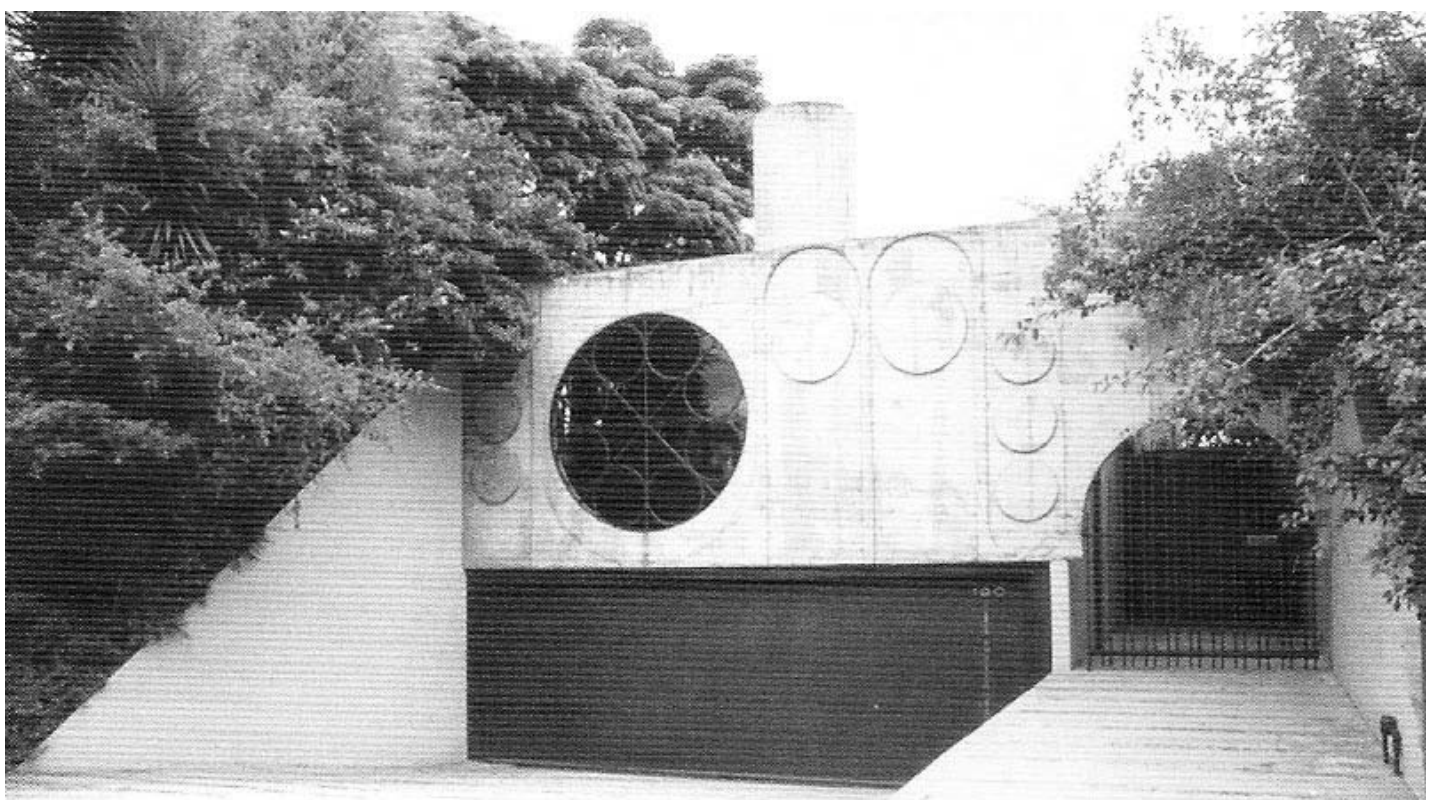

Figura 17 - Residência do José Tadeu de Araújo (1975): frente

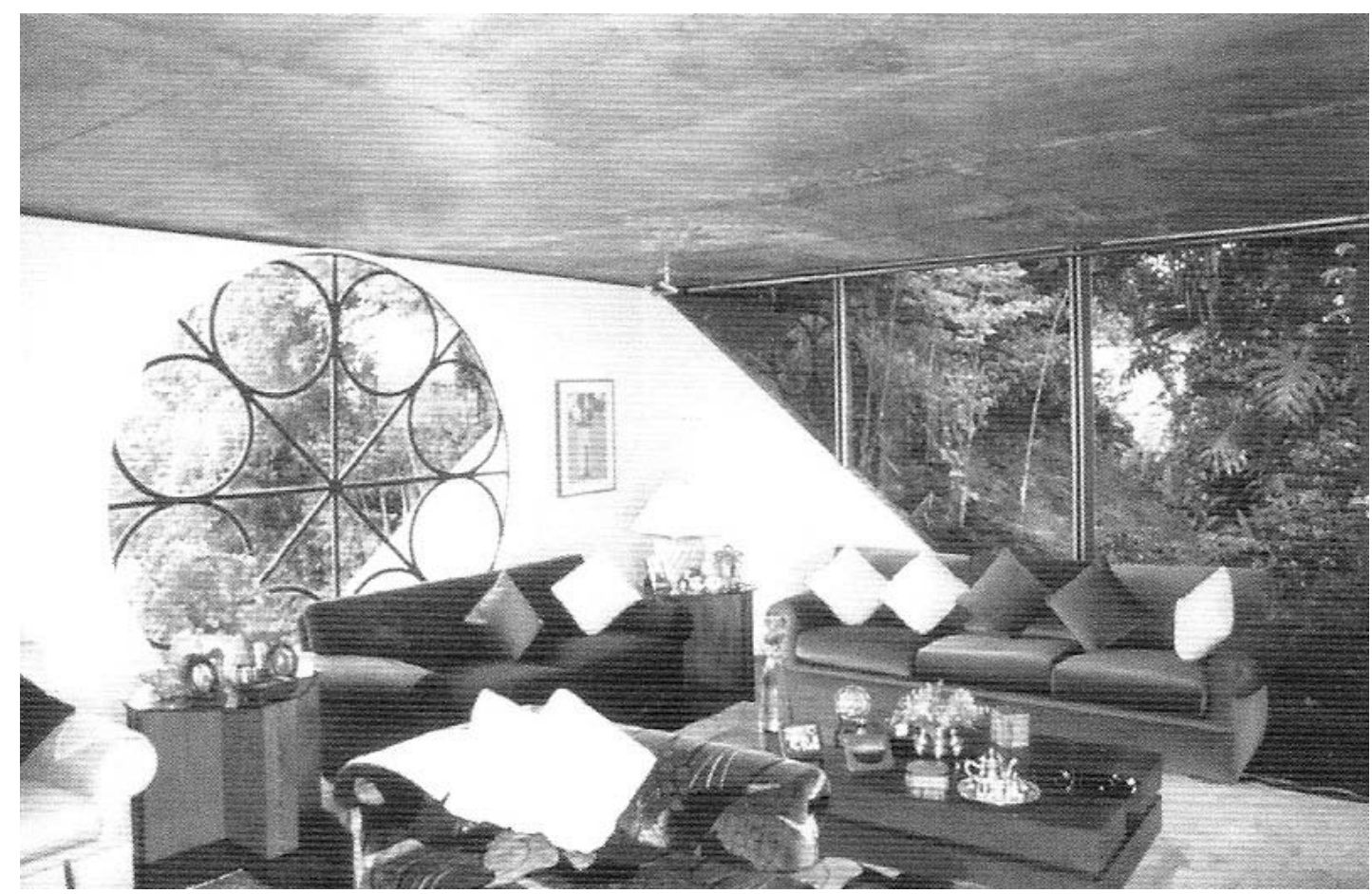

Figura 18 - Residência do José Tadeu de Araújo (1975): interior

Outra residência significativa desse período é a do arquiteto Manoel Coelho. A solução em planta, associada à criação de meios-níveis, resultou numa integração total entre ambientes, integrados em um volume único, sem 
portas (as únicas exceções eram dormitórios, sanitários e cozinha). Em uma discreta homenagem ao arquiteto Kirchgässner, os detalhes construtivos foram pintados em cores primárias, estabelecendo um raro diálogo na arquitetura de Curitiba com as vanguardas dos anos 20 .

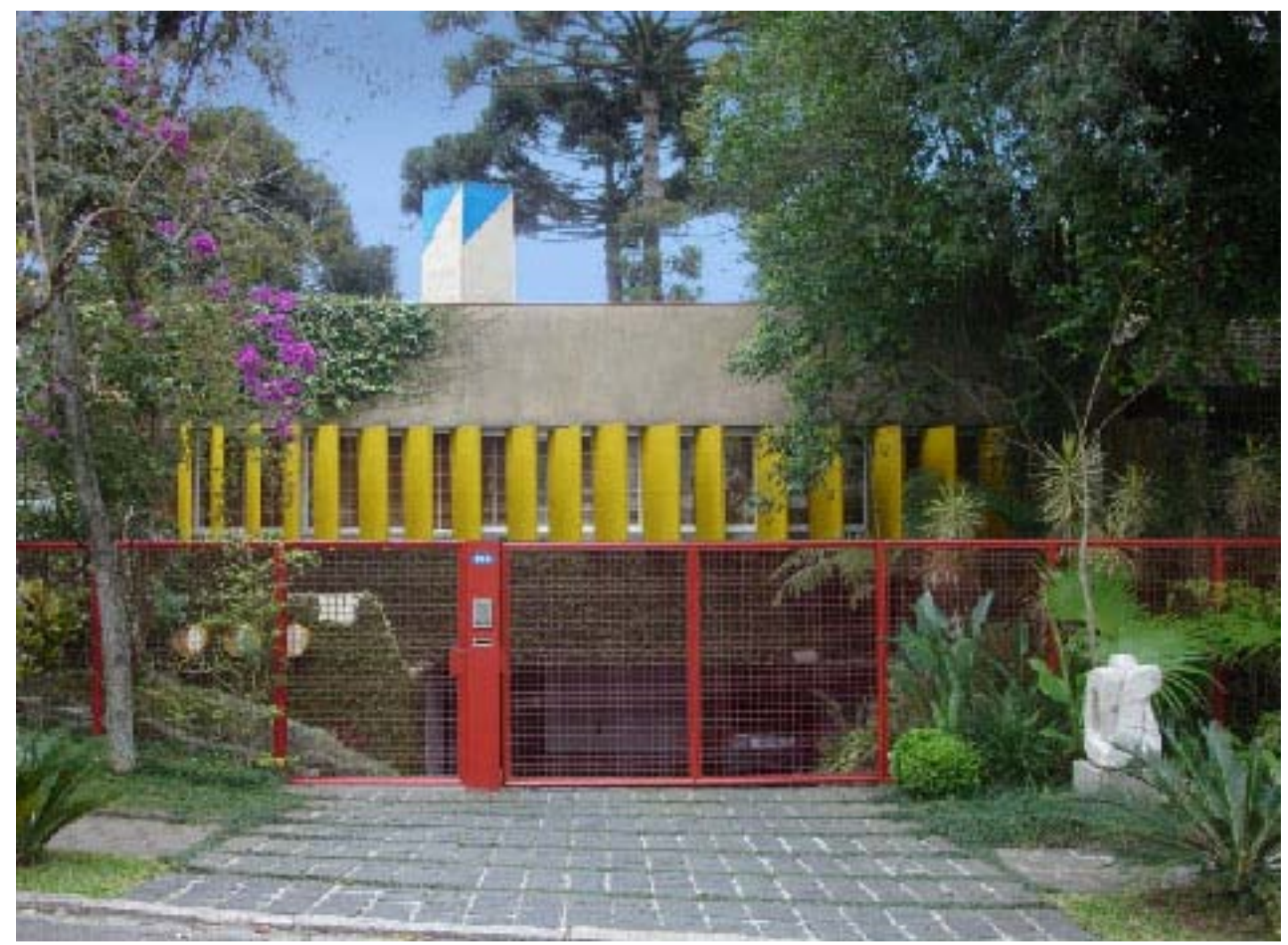

Figura 19 - Residência do Arquiteto Manoel Coelho (1982): frente 


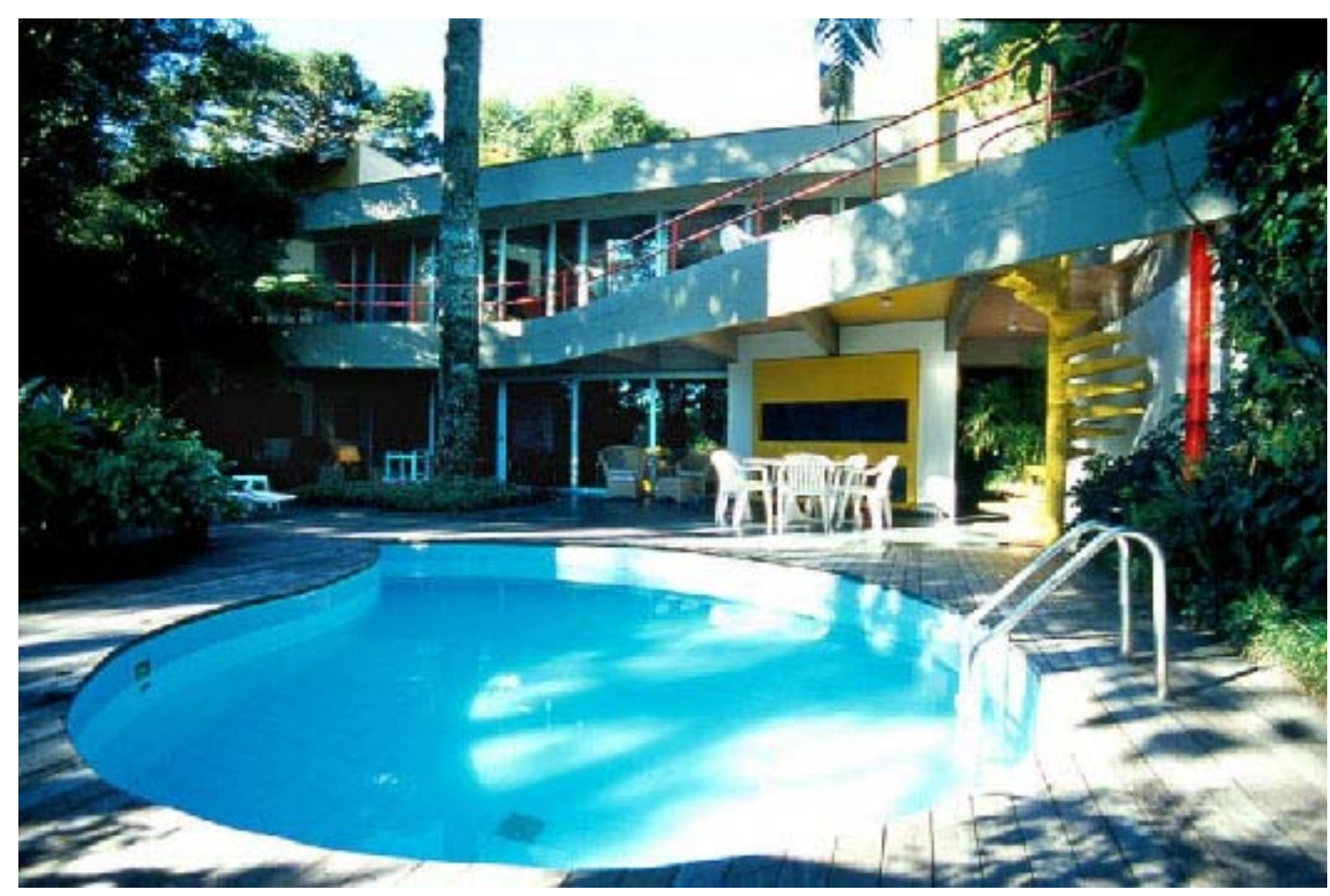

Figura 20 - Residência do Arquiteto Manoel Coelho (1982): fundos

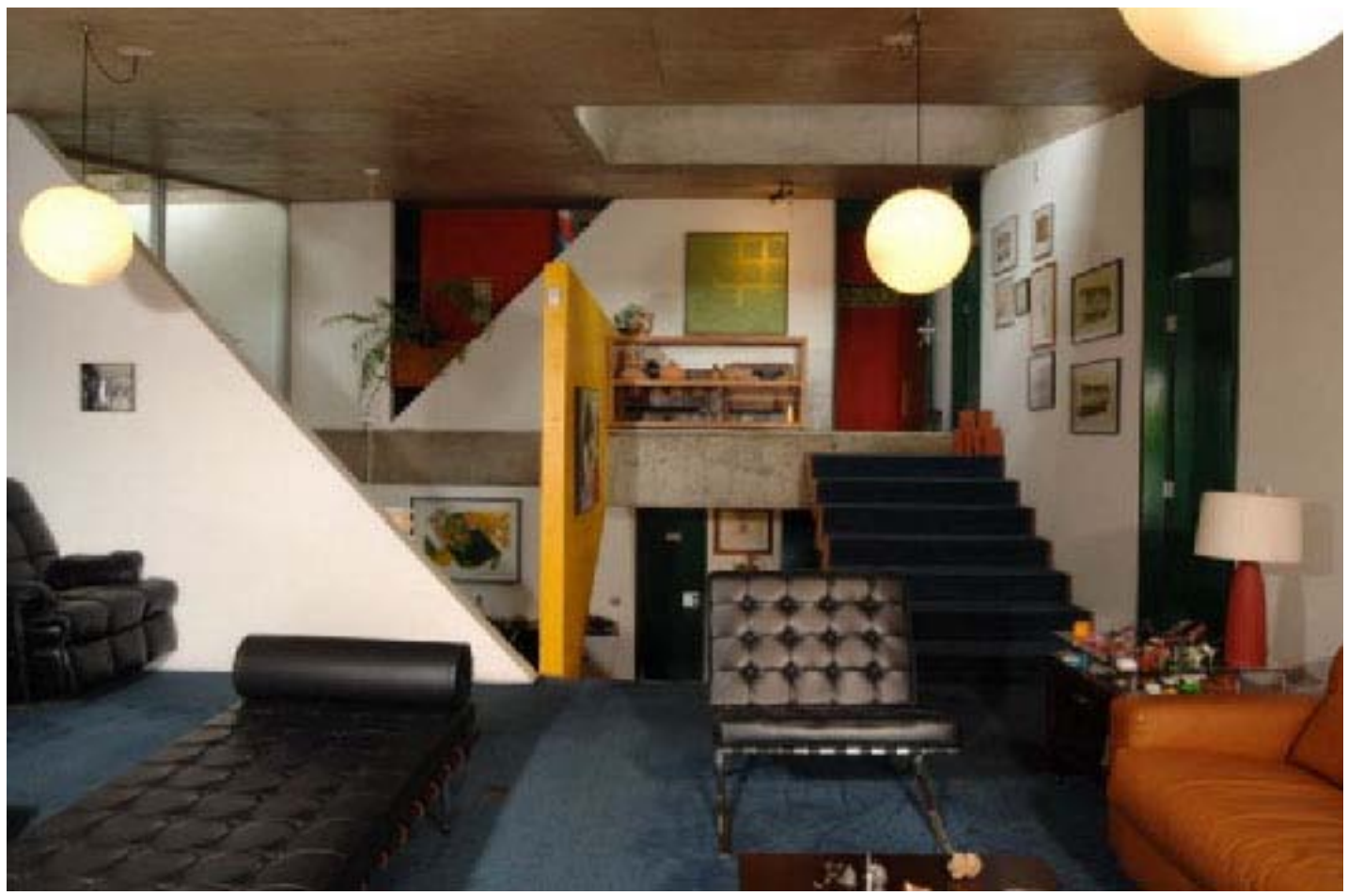

Figura 21 - Residência do Arquiteto Manoel Coelho (1982): interior

No panorama urbanístico, Jaime Lerner, arquiteto formado pela UFPR, foi indicado para o primeiro de dois mandatos, como prefeito da capital 
paranaense. Acompanhado por uma equipe de arquitetos encarregados de diversas funções em seu governo - relacionadas não somente ao planejamento urbano e obras, mas também a órgãos ligados à cultura, artes e administração - uma série de soluções urbanísticas fez com que Curitiba logo se tornasse um modelo de desenvolvimento planejado.

No final da década de 70 , algumas experiências, utilizando madeira, como material para construção de residências, foram decisivas para o que se tornaria a imagem da arquitetura pública de Curitiba, nas décadas seguintes. $O$ arquiteto Oswaldo Navaro Alves, funcionário de carreira do IPPUC, passou a utilizar antigos postes de madeira - de dimensões idênticas e quimicamente tratados para evitar apodrecimento - da Companhia Elétrica do Paraná (COPEL) - como material para a concepção de pequenos equipamentos urbanos, inicialmente, para depois utilizar o material em sua própria residência.

Para a criação de uma obra com esses troncos, Navaro trocou o croqui pela maquete, permitindo que a madeira the indicasse o desenho do projeto. As plantas e cortes da residência foram concebidos a partir da maquete finalizada. O resultado obtido por Navaro foi considerado a primeira obra de organicismo arquitetônico, em Curitiba, sugerindo a influência das obras de Frank Lloyd Wright - não em soluções pontuais, mas na atitude de integração do projeto com a natureza. 


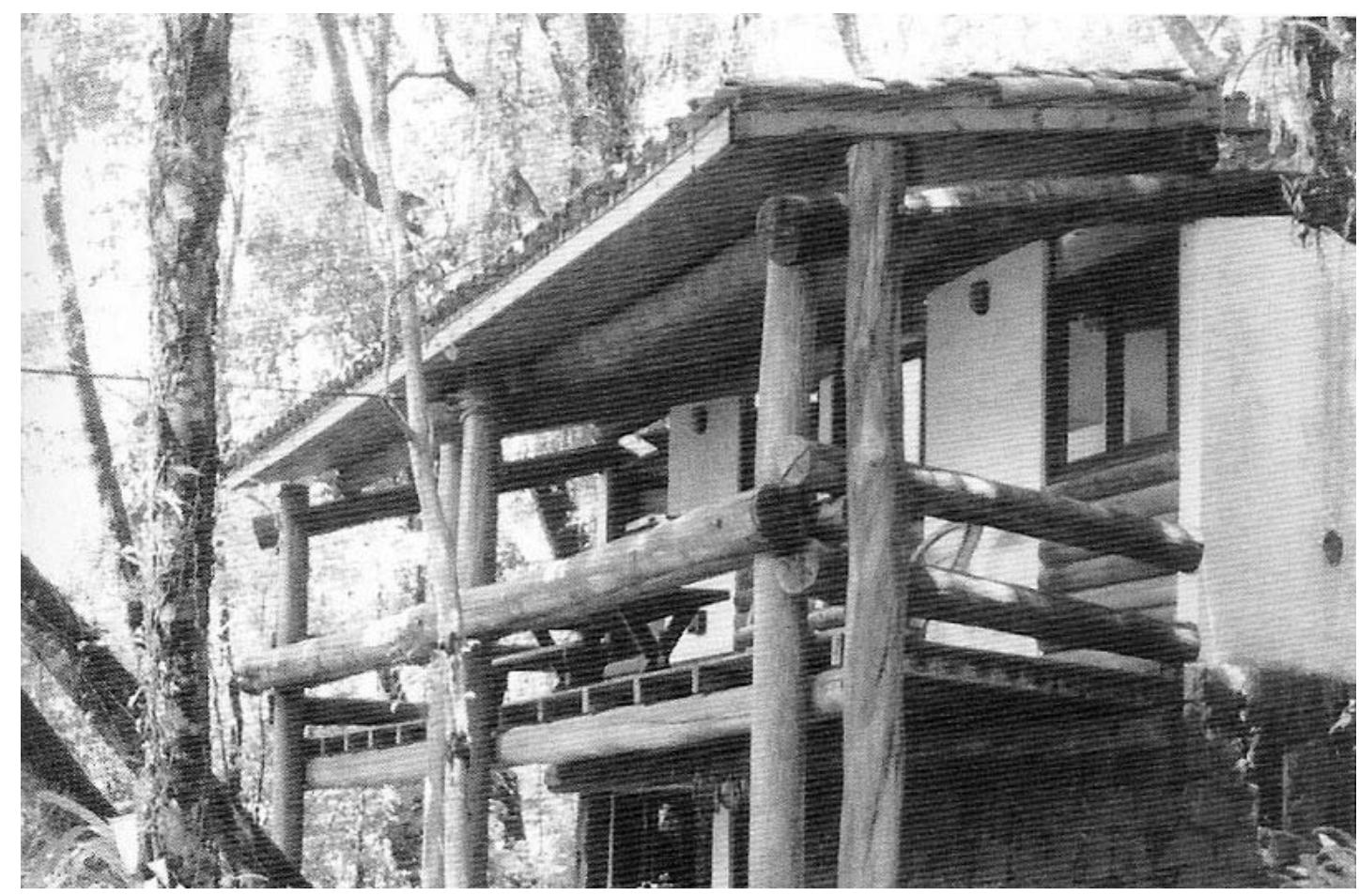

Figura 22 - Residência do Arquiteto Oswaldo Navaro Neves (1977)

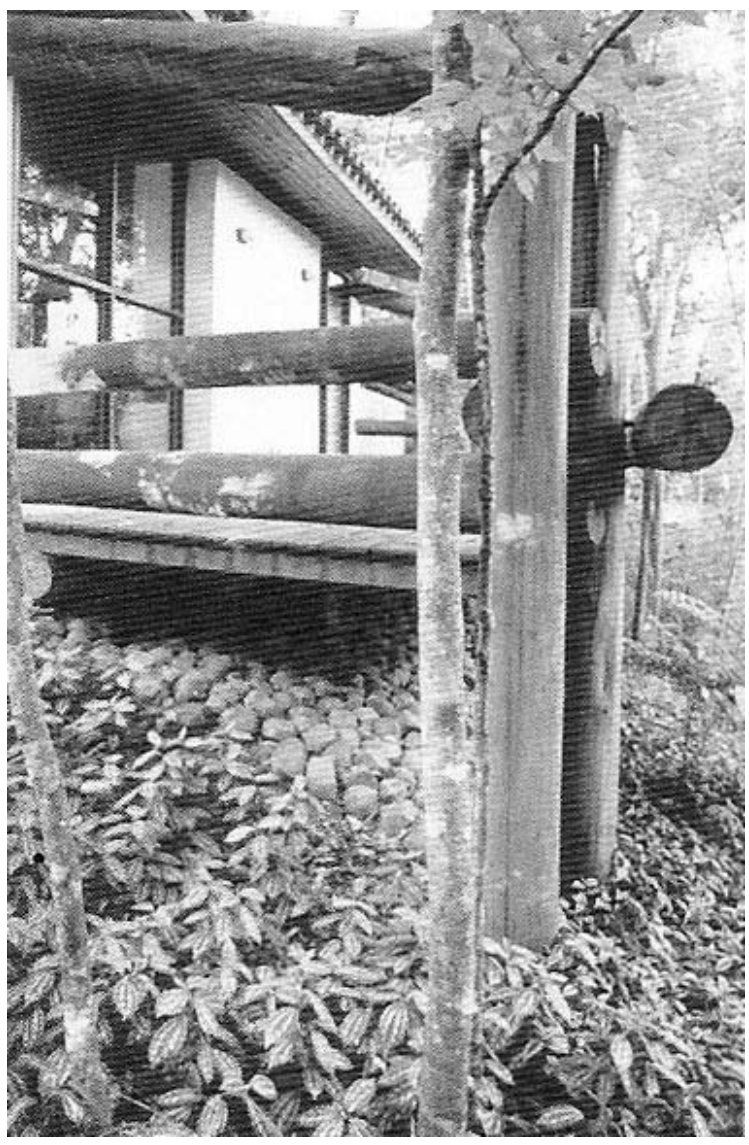

Figura 23 - Residência do Arquiteto Oswaldo Navaro Neves (1977): detalhe tronco 


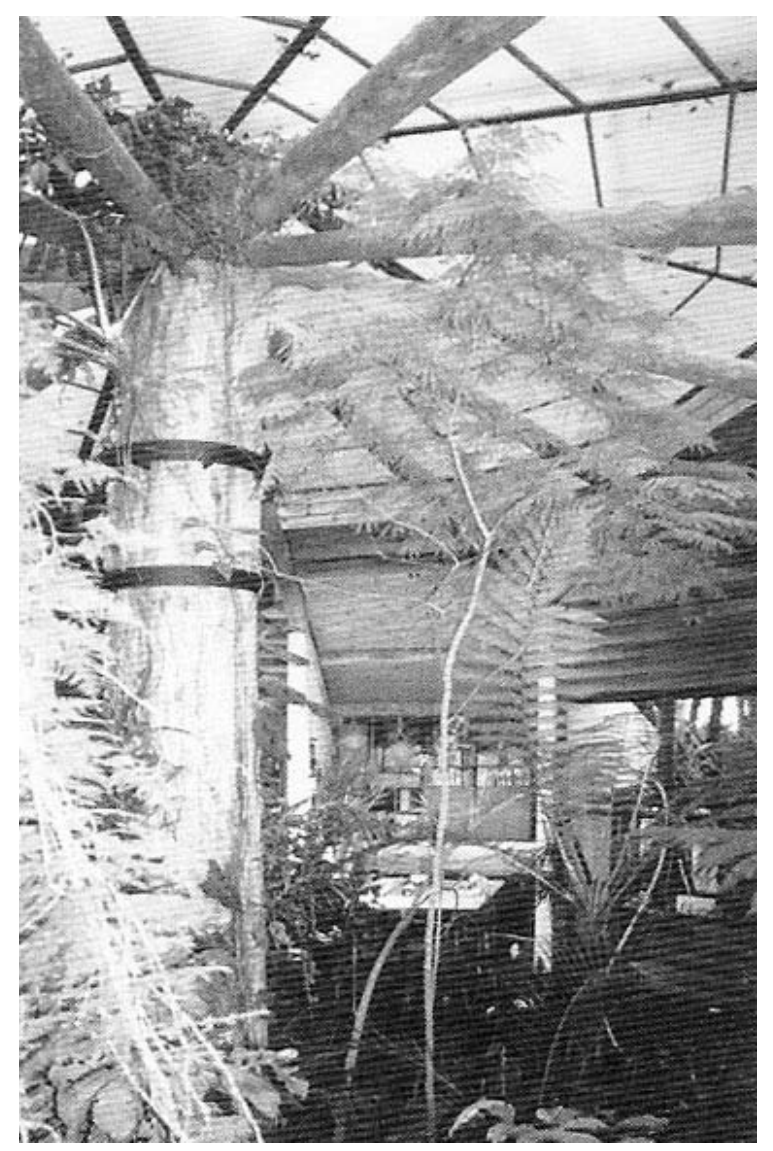

Figura 24 - Residência do Arquiteto Oswaldo Navaro Neves (1977): vista interior

A residência de Navaro foi a principal influência para outro projeto, construído com troncos, da COPEL, o edifício da Secretaria Municipal de Meio Ambiente de Curitiba - SEMMA. A utilização dos troncos nesse projeto possibilitou a construção de 1000m2, com o mesmo orçamento, dos 300ms que poderiam ser construídos com tecnologias tradicionais, evidenciando a economia desse método construtivo, que se tornaria marca registrada da arquitetura pública de Curitiba.

\section{7. $\quad 0$ surgimento de uma identidade}

O contexto político desfavorável e a repercussão da Bienal de Veneza resultaram no surgimento de uma nova geração de arquitetos, em Curitiba, que passou a adotar o pós-moderno como nova regra de projeto, sem se preocupar em questionar sua validade ou transpor o significado desta nova tendência 
para realidade da cidade. Obras dotadas de referências díspares e incongruentes se espalharam pela cidade, buscando espaço no mercado, com apelações de gosto duvidoso. Curitiba foi tomada por arcos, sancas, colunas gregas e tantos outros apêndices construtivos, buscando dar às construções uma casca decorativa.

Em oposição a este discurso, algumas experiências garantiram a continuidade às experiências arquitetônicas das décadas anteriores, comprometidas com a busca de soluções para o impasse entre os avanços tecnológicos e memória curitibana. Na arquitetura institucional, o uso de troncos de madeira se tornaria uma característica dos projetos paranaenses. Os projetos para a Universidade Livre do Meio Ambiente e no Centro de Pesquisas da COPEL, ambos projetados por Domingos Bongestabs, além do Memorial dos 300 Anos de Curitiba, concebido pelos arquitetos Fernando Popp, Jaime Lerner e Valéria Bechara, evidenciariam a versatilidade e complexidade da solução criada por Navaro.

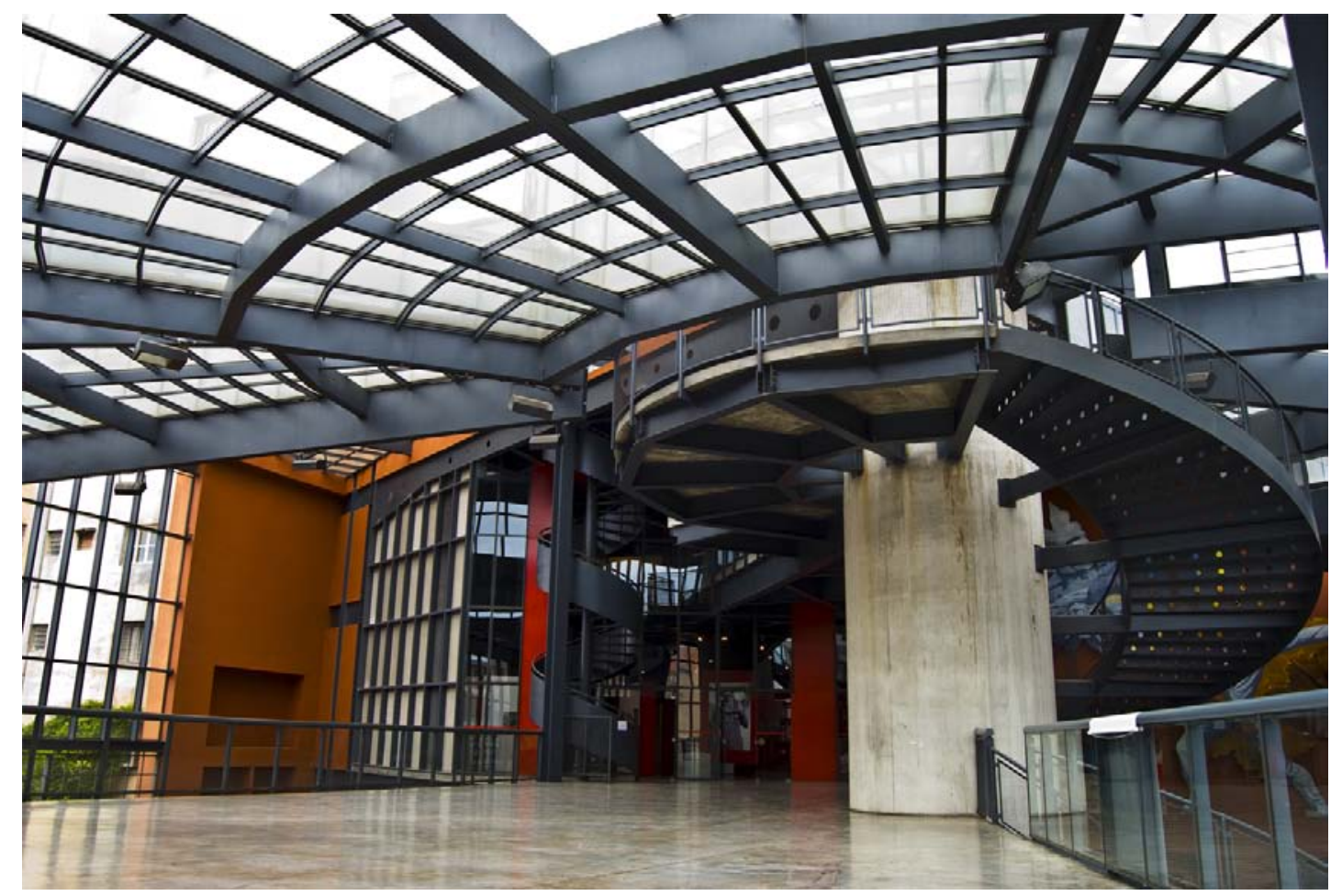

Figura 25 - Memorial dos 300 Anos de Curitiba (1994) 


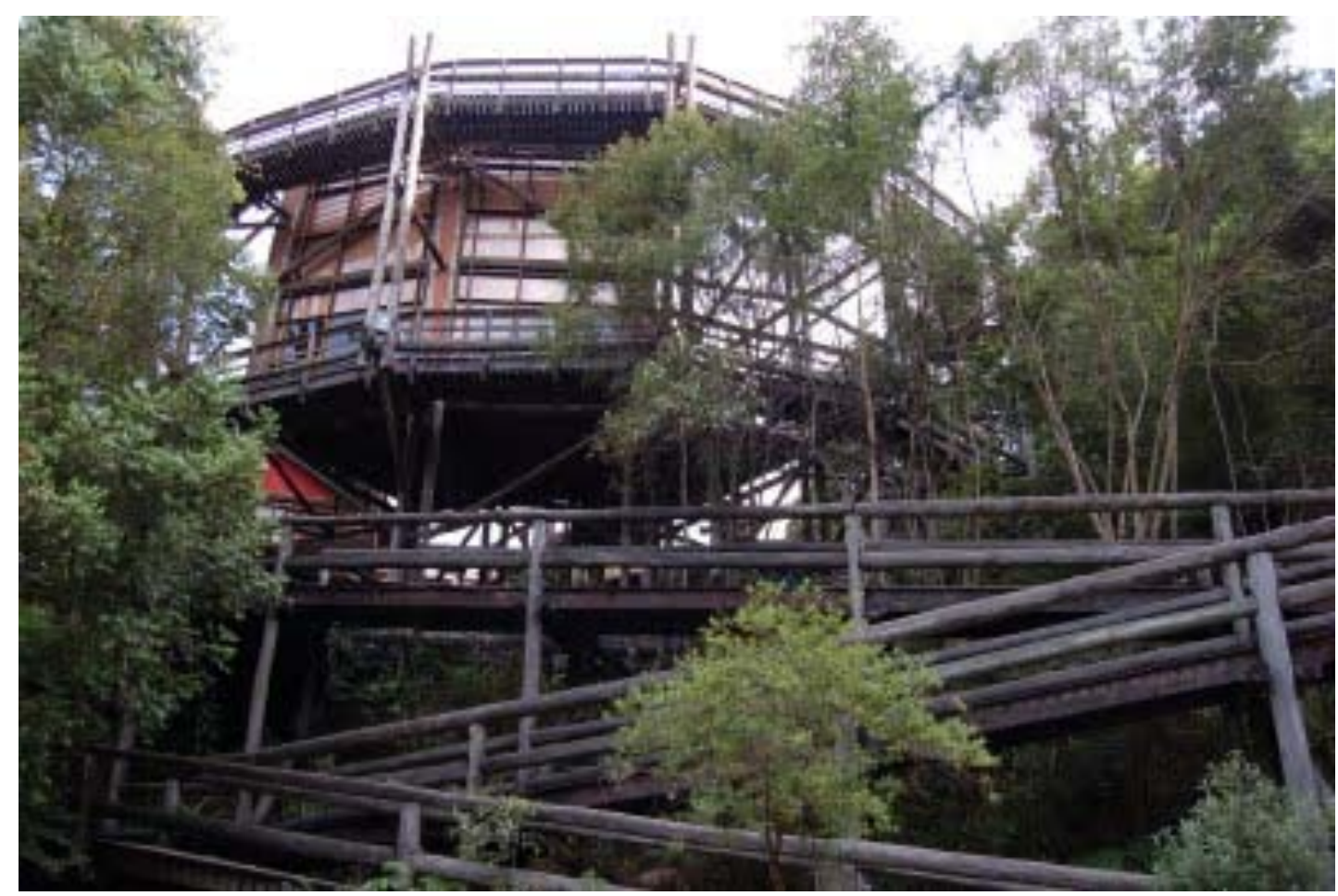

Figura 26 - Universidade Livre do Meio Ambiente (1992)

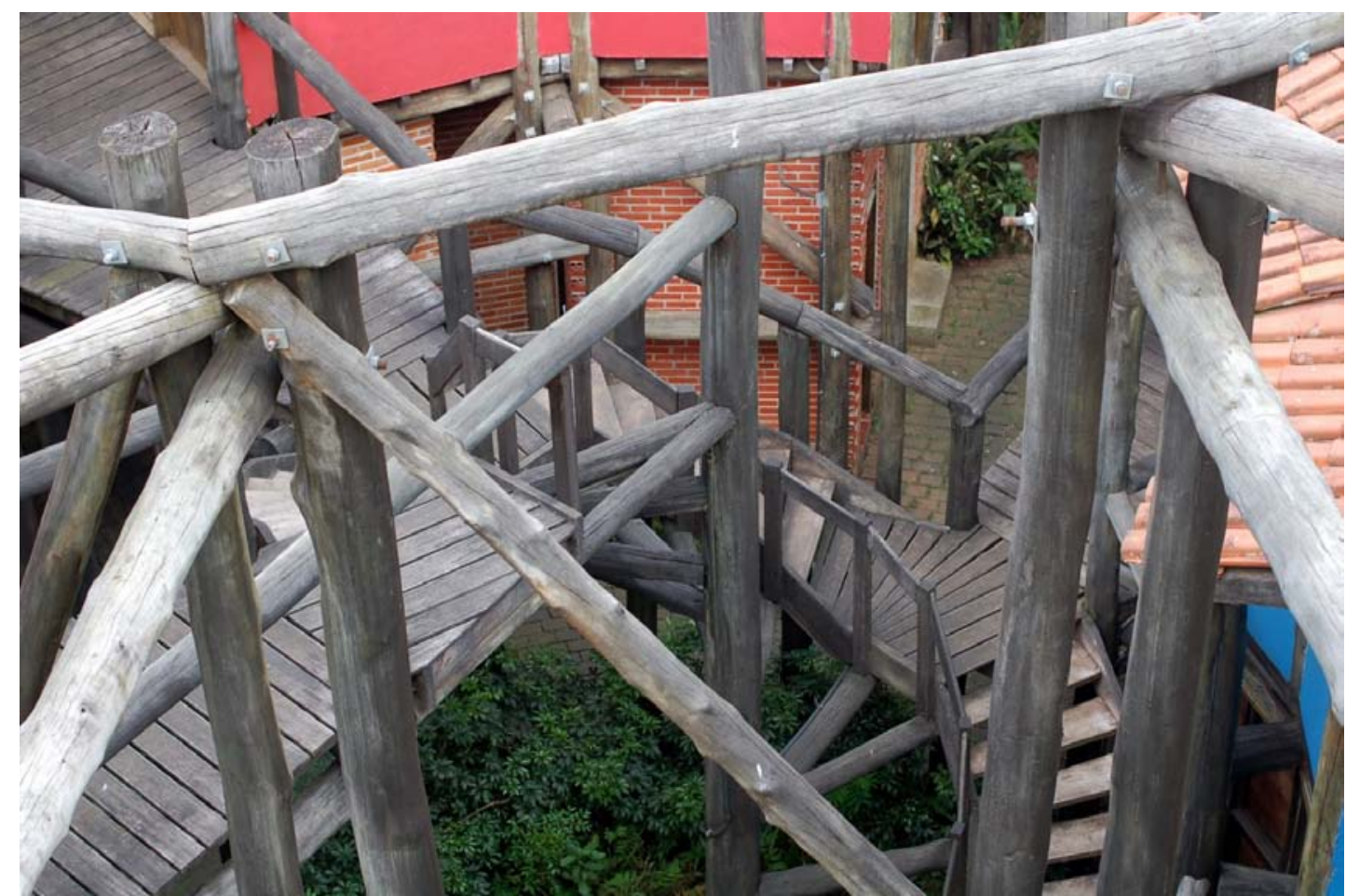

Figura 27 - Universidade Livre do Meio Ambiente (1992): troncos

Nas obras residenciais, observamos a retomada da busca pela identidade paranaense, após o período de crise da década de 80 . A procura de 
novos caminhos para arquitetura, com diferentes estilos e tendências, surgindo a partir de uma revisão da crítica do modernismo.

Este trabalho se propõe analisar a arquitetura residencial de Curitiba, realizada a partir do ano 2000, na expectativa de compreender o cenário arquitetônico atual e sua relação com a produção no Brasil e com a arquitetura internacional.

\section{PRINCIPAIS TENDENCIAS DA ARQUITETURA CONTEMPORANEA}

Para análise das obras selecionadas, este trabalho considerou a formulação proposta pelo arquiteto Josep Maria Montaner, no seu livro Depois do movimento moderno: Arquitetura da segunda metade do século $X X$, na qual o autor considera a existência de seis posturas arquitetônicas predominantes da arquitetura contemporânea ${ }^{19}$. A estas, foram acrescentadas mais duas posturas, mencionadas por Montaner na conclusão de seu livro, como essenciais para a compreensão da arquitetura a partir dos anos 90: 0 minimalismo e a arquitetura ecológica. O conceito de "postura arquitetônica" se baseia na consideração de que a atividade de certos arquitetos oferece diferentes opções de linguagem, tecnologia, materiais, tipos de espaço e relação com a cidade. Algumas destas opções mantém certa coerência e permitem delimitar certas posturas determinantes.

As posturas arquitetônicas predominantes que serão desenvolvidas neste trabalho são oito: o revival historicista, baseado na recuperação da linguagem classicista; a continuidade do contextualismo cultural, relacionado primordialmente os valores urbanos e históricos de cada obra; a versatilidade do ecletismo, baseada na busca de novas formas a partir da fusão e "colagem" de linguagens e convenção existentes; o paradigma da singularidade da obra de arte; o surgimento de uma nova abstração baseada no jogo formal; a continuidade no uso da alta tecnologia; o minimalismo; e finalmente, as arquiteturas ecológicas.

\footnotetext{
${ }^{19}$ MONTANER, Josep Maria. Después del movimiento moderno: arquitectura de la segunda mitad del siglo XX. Barcelona: Gustvao Gilli, 1993.
} 
Com esse desdobramento de tendências ou atitudes predominantes pretende-se detectar temas transcendentais na arquitetura recente, ou seja, aquelas questões que se situam no centro de sua evolução atual.

Ao contrario de propor um panorama feito exclusivamente por individualidades, é necessário propor certa ordem de interpretação. Tal como ressaltou Claude Lévi-Strauss:

Por trás da diversidade desconcertante dos feitos que se oferecem a observação empírica podem ser encontradas algumas propriedades invariantes diferentemente combinadas ${ }^{20}$

\section{a) Revival historicista}

Esta tendência, também denominada "populismo" no livro História Crítica da Arquitetura Moderna de Kenneth Frampton ${ }^{21}$, ou simplesmente "pósmodernismo", caracterizou-se como uma resposta a perda de capacidade significativa da arquitetura do Estilo Internacional. Charles Jencks, em seu livro El lenguaje de la arquitectura posmoderna (1981) definiu este movimento como uma arte populista e pluralista, que tinha como objetivo assegurar a comunicação com o usuário, o ressurgimento de uma capacidade significativa da arquitetura ${ }^{22}$. Para isto, os arquitetos recorriam ao recurso da tradição, a reutilização de um sistema de convenções aceitas.

Neste ponto, é importante ressaltar que arquitetura "pós-moderna" tornou-se um termo ambíguo, podendo referir-se a uma condição geral - a condição pós-moderna, sobre a qual discorreu em livro homônimo o filósofo francês Jean-François Lyotard arquitetura ${ }^{23}$ - como para designar tendências da arquitetura marcadamente historicistas, hedonistas ou densas em citações.

\footnotetext{
${ }^{20}$ LEVI-STRAUSS, Claude. Antropologia estrutural II. Cidade do México, Siglo XXI, 1979.

${ }^{21}$ FRAMPTON, Kenneth. História crítica da arquitetura moderna. São Paulo: Martins Fontes, 1997.

22 JENCKS, Charles. El lenguaje de la arquitectura posmoderna. Barcelona: Gustvao Gilli, 1981.

${ }^{23}$ LYOTARD, Jean-François. The postmodern condition. Manchester: Manchester University Press, 1984.
} 
Esta recorrência as convenções, ao que é aceito de maneira acrítica e que é celebrado pelo público, parte da ideia de que a arquitetura é essencialmente mensagem e linguagem. Em grande parte das vezes, recorrese ao sistema expressivo do classicismo, ao conforto e prestígio das linguagens clássicas, não raramente renunciando aos experimentos inovadores.

Ao longo dos anos 80 , apesar das inúmeras críticas a esta arquitetura "pós-moderna", uma enorme quantidade de arquitetos optou por esse caminho, especialmente nos Estados Unidos: Michael Graves, Robert A. M. Stern, Allan Greenberg e outros. Também na Europa, especialmente em cidades com uma sólida tradição histórica, arquitetos de diferentes tendências, mas que tem em comum esse recurso à arquitetura histórica tradicional, propagaram esta arquitetura em diversos contextos culturais: Charles Vandenhoeven e Maurice Coulot na Bélgica; Charles Jencks e Terry Farrell na Grã-Bretanha; Ricardo Bofill e Oscar Tusquets na Espanha.

Simulando cenograficamente o clássico e o vernáculo, reduzindo desta forma a tectônica da construção a uma simples paródia, as duas décadas de experimentação do historicismo revival demonstrou que pouquíssimos arquitetos europeus ou norte-americanos que tentaram recriar esse classicismo pós-moderno conseguiram desenvolver uma linguagem própria e qualitativamente nova.

Um dos pontos mais criticados deste revival historicista é sua tendência em evitar conquistas transcendentais da arquitetura do século $\mathrm{XX}$ : as possibilidades da planta livre, a necessária qualidade do espaço interior e do exterior, a expressão da leveza e dinamicidade da edificação, tendência a resolver de maneira simples e direta os problemas, a capacidade expressiva das estruturas aparentes.

Esta arquitetura retorna aos volumes fechados e estáticos, tipologias anacrônicas, ou as formas convencionais do vernáculo, renunciando o caminho já percorrido pela arquitetura do século $\mathrm{XX}$ e pelas novas possibilidades tecnológicas. Caracteriza-se como uma postura conservadora, que procura recriar o conforto das linguagens sob todos os aspectos fora de época. 
No contexto particular da cidade de Curitiba, esta tendência foi interpretada de forma equivocada na grande maioria das obras influenciadas por este classicismo pós-moderno. O que diferencia os projetos locais dos exemplos considerados relevantes dentro desta tendência preocupada com o significado da tradição é o fato de que grande parte das obras identificadas em Curitiba não hesita em recorrer de maneira literal às linguagens do passado: frontões triangulares, colunas clássicas e outros elementos da linguagem clássica voltam a aparecer diretamente sem nenhuma vontade de experimentação, reelaboração ou abstração, senão que aproveitam ao máximo a corrente de aceitação popular que gera a recriação de convenções.

Por este motivo, após uma análise preliminar de alguns exemplos relacionados com o revival historicista em Curitiba, devido à ausência de qualquer embasamento teórico que justifiquem as decisões de projeto destas obras, optou-se por não incluir residências ligadas a esta tendência na seleção final de projetos.

\section{b) Contextualismo cultural}

O contextualismo cultural defende a criação de uma arquitetura que volte a se situar entre os bens culturais do homem e seja entendida como criação de lugares significativos, no sentido concreto e fenomenológico da palavra. Coloca o contexto urbano e cultural no centro do processo de projeto, dando continuidade as ideias assinaladas por Ernesto Nathan Rogers, defendendo o realismo e a adaptabilidade à tradição do lugar e as preexistências ambientais.

Dois textos essenciais fundamentaram as bases teóricas desta corrente que se tornou expressiva em diversos contextos europeus: $A$ arquitetura da cidade (1966), de Aldo Rossi ${ }^{24}$, e La costruzione logica dell'architettura (1967), de Giorgio Grassi ${ }^{25}$. Embora o caso italiano seja o mais claro, também na Espanha encontramos exemplos destacados nesta tendência

\footnotetext{
${ }^{24}$ ROSSI, Aldo. A arquitetura da cidade. São Paulo: Martins Fontes, 1995.

${ }^{25}$ GRASSI, Giorgio. La construzione logica dell'architettura. Milão: Franco Angeli, 2008.
} 
nos projetos dos arquitetos Rafael Moneo e Juan Navarro Baldeweg e em Portugal, nas obras de Álvaro Siza e Eduardo Souto de Moura.

A obra de Siza em particular, é marcada por uma arquitetura ao mesmo tempo racionalista e organicista, com grande capacidade de adaptação. A inspiração nos elementos específicos do lugar e o diálogo com os usuários se converte em ponto de partida do projeto. Em suas obras, Siza recria a ideia do lugar, e a relação material do projeto com o contexto, evidenciando a afinidade de sua arquitetura com determinadas posturas de arquitetos nórdicos como Jorn Utzon e Alvar Aalto.

Nas obras situadas em Curitiba analisadas para este trabalho, foi possível identificar alguns casos relacionados com esta tendência, que situa o lugar como ponto central do problema arquitetônico, mas de forma parcial e específica. Em decorrência do fenômeno da proliferação de condomínios fechados na cidade, a maioria das casas selecionadas para este projeto localizava-se dentro destes loteamentos urbanos privados. As casas situadas dentro dos condomínios podem ser analisadas em relação ao local onde estão inseridas nos quesitos de topografia, pré-existências ambientais, diálogo com obras adjacentes - também inseridas na realidade utópica do condomínio fechado - e necessidades dos futuros proprietários. Entretanto, as característica particulares estabelecidas dentro de um condomínio fechado e o distanciamento da sua realidade com as questões sociais e urbanas comum a realidade da cidade impede a contextualização da obra com o meio urbano em um sentido amplo.

As obras deste trabalho que demonstraram influencia e afinidade com esta postura arquitetônica apresentam soluções que buscam a adaptação do projeto à topografia existente e as preexistências ambientais - luz, ventos dominantes, adequação dos matérias escolhidos ao clima local - mas não se relacionam com questões urbanas ou sociais comuns a cidade por se encontrarem em um contexto isolado.

\section{c) Ecletismo}


ecletismo se caracteriza como uma atitude contextualista, baseada na mescla e no contraste, que pretende dialogar com as características, história e cultura do lugar onde se insere. É uma postura que tem como objetivo atingir novos resultados formais a partir da utilização de figurações e referências de origens diversas.

Os projetos influenciados pelo ecletismo tendem a apresentar soluções híbridas, superposição de peles, agregação e "colagem".

A exposição realizada em 1980 para a Bienal de Veneza intitulada "A presença do passado" foi um dos exemplos mais claros de manifestação do ecletismo. Organizada e concebida pelo arquiteto italiano Paolo Portoguesi, tratava-se de um manifesto da arquitetura contextualista, no qual vinte arquitetos foram selecionados para projetar estandes com uma fachada de $7 \mathrm{~m}$, no espaço definido entre as colunas do edifício da exposição. Entre os arquitetos participantes - entre eles Rem Koolhaas/Elia Zenghelis (OMA), Frank Gehry, Arata Isozaki, Michael Graves, Charles Moore e outros - foi a obra de Hans Hollein que apresentou características mais claras ligadas a corrente do ecletismo.

O austríaco Hans Hollein desenvolveu, ao longo dos anos 70, um trabalho de cunho artístico pessoal, relacionado com o desenho e arte conceitual. $\mathrm{O}$ arquiteto trabalhou com cenografia em exposições e peças de teatro, montagens de instalações e intervenção em decorações de lojas em Viena. Seu projeto do Museu Municipal, em Mönchengladbach (1972-1982), é uma das obras mais emblemáticas da arquitetura ecletista que utiliza continuamente a metáfora. Além de Hollein, James Stirling, Arata Isozaki e Philippe Starck, entre outros, estão entre os principais expoentes da arquitetura ligada a corrente do ecletismo.

$\mathrm{Na}$ cidade de Curitiba, o ecletismo foi encontrado como influencia de algumas obras, principalmente na arquitetura comercial e em projetos de decoração de vitrines e instalações temporárias. Esta arquitetura de "colagem" não pode ser identificada com clareza na arquitetura residencial contemporânea, por este motivo o tema não foi desenvolvido na análise final das residências. 


\section{d) A obra de arte, paradigma da arquitetura}

Ao longo da história, a arquitetura buscou modelos que a legitimassem e estruturassem em certa direção. A natureza, os modelos do classicismo, o bosque nórdico, a técnica, foram alguns dos paradigmas empregados. Com o final da Segunda Guerra Mundial, essas referências se multiplicaram e se dispersaram: a busca pela participação do usuário, a capacidade comunicativa da arquitetura, a referência às tipologias tradicionais, os avanços tecnológicos, etc.

De acordo com o crítico Josep Maria Montaner ${ }^{26}$, no final do século XX, um segmento da arquitetura procurou a legitimização na obra de arte e nos seus componentes, buscando uma nova forma de estruturar seus processos de investigação formal. Essa tendência teve como objetivo se afastar da produção em série, ocasionada em grande parte pelo avanço da tecnologia e tecnificação mundial.

Esse posicionamento já havia sido observado em meados da década de 60, na arquitetura italiana do pós-guerra. Um exemplo claro são os projetos apresentados por Giulio Carlo Argan em seu texto de 1965, Projeto e Destino ${ }^{27}$. Argan interpreta a obra artística como argumento que critica a vertigem, o consumismo e perda de qualidade, coadjuvante da produção industrial e seriada. Não por acaso, os italianos - Scolari, Rossi, Portoghesi - foram os primeiros a introduzir os esboços arquitetônicos no mercado da arte e no espaço das galerias.

A própria historiografia da arte, em especial a obra do crítico Ernst Gombrich, colocou em circulação uma interpretação baseada em situar o sujeito artista e sua resposta psicológica ao contexto no centro da história da arte. Em 1979, em seu livro Historia da Arte, Gombrich afirma:

Uma coisa que realmente não existe é aquilo que se dá o nome de

Arte. Existem somente artistas. Outrora, eram homens que

\footnotetext{
${ }^{26}$ MONTANER, Josep Maria. Después del movimiento moderno: arquitectura de la segunda mitad del siglo XX. Barcelona: Gustvao Gilli, 1993.

${ }^{27}$ ARGAN, Giulio Carlo. Projeto e destino. Rio de Janeiro: Editora Ática, 2000.
} 
apanhavam terra colorida e modelavam toscamente as formas de um bisão na parede de uma caverna; hoje, alguns compram suas tintas e desenham cartazes para os tapumes. Eles faziam e fazem muitas outras coisas. Não prejudica ninguém chamar todas essas atividades de arte, desde que conservemos em mente que tal palavra pode significar coisas muito diferentes, em tempos e lugares diferentes, e que Arte com A maiúsculo não existe. ${ }^{28}$

Este posicionamento fica bastante evidente nos Estados Unidos a partir da década de 60, especialmente pela atuação do grupo SITE (Sculpture in the Environment). Liderado por James Wines, o SITE desenvolveu algumas propostas, influenciadas pela pop art e pela arte conceitual norte-americana, nas quais o grupo buscava a interação entre arte, arquitetura e escultura ambiental.

Essa tendência, além de ser uma das mais evidentes dos últimos anos no terreno da arquitetura, é uma das consequências da crise dos projetos produtivistas, funcionalistas e racionalistas do Movimento Moderno. O arquiteto tenta desenvolver um método arquitetônico que busque se aproximar dos mecanismos da criação artística, se afastando da produção em série e da industrialização radical. As obras definem uma relação única com o contexto, com o usuário ou com as arquiteturas pré-existentes no contexto no qual se insere. Os arquitetos, influenciados por esta tendência buscam se distanciar da produção em massa, buscando no método da arte um direcionamento para o seu trabalho.

Um dos exemplos mais claros observados na arquitetura internacional influenciados por esta corrente está na obra de Frank Gehry. Autoral e escultórica, a obra de Gehry é marcada pela experimentação formal e exploração das qualidades plásticas de materiais pouco utilizados até então na arquitetura - papelão, arame, telas metálicas, estuques semi-industriais, placas de titânio.

Alguns arquitetos que se enquadram nesta tendência traçaram um caminho profissional pouco usual. Primeiro, dedicaram-se a trabalhos

${ }^{28}$ GOMBRICH, E.H. História da Arte. Rio de Janeiro, Guanabara, 1978. 
arquitetônicos experimentais e poéticos, que permitiram a eles ir configurando uma linguagem própria, inovadora e aberta, ganhando espaço e reconhecimento em publicações de arquitetura. Desta etapa - muitas vezes simultânea a atividade de ensino de arquitetura - partem para a produção arquitetônica real, especialmente através da participação em concursos arquitetônicos. É o caso de Bernard Tschumi, Rem Koolhaas e Elias Zenghelis (OMA), Adolfo Natalini (Superstudio), ou Prix e Swiczinsky (Coop Himmelblau).

Algumas obras em Curitiba parecem se aproximar desta tendência arquitetônica e dos aspectos positivos desta relação entre arte e arquitetura: enriquecimento do repertório formal, maior capacidade de comunicação, facilidade de adaptação ao meio, etc. Embora seja observada com mais frequência em tipologias específicas - bares, hotéis, museus, galerias observa-se que algumas residências tiram partido desta linha de pensamento que aproximam desta forma de pensar e compreender a arquitetura. Nas residências analisadas, observa-se que quando esta tendência aparece no projeto, ela não é uma influência única e isolada, mas sim simultânea com outras correntes e linhas de pensamento da arquitetura.

\section{e) A nova abstração formal}

A arquitetura da nova abstração formal é derivada em grande parte dos estudos e mecanismos abertos no final dos anos 80 por Peter Eisenman e John Hedjuk. A sequência de escritos de Eisenman, juntamente com suas obras, representa a proposta teórica mais definida de um período, os anos 80 , que foram marcados pela dispersão e ausência de teoria. A obra de Eisenman se relaciona com a cidade grande, com o caos das metrópoles, sua densidade, seu caráter labiríntico e contraditório, o mesmo universo que serve como ponto de partida e referência para os arquitetos do OMA, Bernard Tschumi, etc.

Este posicionamento rejeita à recorrência à história e à vontade comunicativa da arquitetura das décadas anteriores, se situando no extremo oposto das tendências que defendem a relação com o genius loci, memória do lugar ou universo do ecletismo. É na verdade uma reação às tipologias 
estáticas propostas a partir dos anos 60 por Aldo Rossi e seus seguidores. Nas palavras de Montaner:

\footnotetext{
Trata-se indubitavelmente da arquitetura que tende a falar mais dos tempos atuais, da desordem do mundo contemporâneo, da debilidade de toda ação do homem, da insegurança dos nossos conhecimentos e da perda irrecuperável de nossa relação com o lugar e com a história. ${ }^{29}$
}

Esta tendência se aproxima de certos processos próximos às correntes conceituais de arte contemporânea e também das consequências do pensamento pós-estruturalista (especialmente de Foucault e Derrida). Ao aceitar a condição efêmera do homem moderno e entender o período atual como o início de uma época não clássica, essa arquitetura se distância da tendência de colocar o homem em primeiro plano, seja como usuário ou como receptor de mensagens da arquitetura. Renuncia os princípios da arquitetura ingenuamente comunicativa, buscando em suas formas e espaços novas propostas e novos caminhos.

A nova abstração formal busca uma arquitetura com uma nova ideia de espaço, dinâmico e não ortogonal, representando sua relação com um mundo mais autônomo e perfeito, no caso, o mundo da geometria. Procura ainda se expressar através de novos modos de representação - mediante esboços superpostos, maquetes, perspectivas e simulações em computador - ao invés das convencionais perspectivas, plantas e cortes.

Esta arquitetura abertamente experimental e não limitada a um único estilo definido teve sua origem nos anos 80 , nas escolas de arquitetura angloamericanas mais experimentais: a Architectural Association de Londres, dirigida por Alvin Boyarsky, e a Cooper Union de Nova York, promovida por John Hedjuk. Obteve grande repercussão na segunda metade desta mesma década, quando surgiram as primeiras gerações de arquitetos mais jovens formados nesta nova corrente abstrata. Bernard Tschumi, Zaha Hadid, Rem

\footnotetext{
${ }^{29}$ MONTANER, Josep Maria. Después del movimiento moderno: arquitectura de la segunda mitad del siglo XX. Barcelona: Gustvao Gilli, 1993.
} 
Koolhaas, Elia Zenghelis e outros, foram influenciados diretamente por Peter Eisenman; já Daniel Libeskind, criador de um sistema formal próprio, relacionado com a escultura, a matemática e a música, foi influenciado pela busca especulativa de John Hedjuk.

Se Eisenman e Hedjuk partiam de Le Corbusier e dos futuristas italianos, esta nova geração se deslocou para uma reinterpretação aberta e exaustiva das diferentes vanguardas soviéticas - construtivistas, suprematistas, etc. - e dos diferentes autores: Malevich, El Lissitzky, Leonidov, Chernikov, Tatlin, Melnikov, etc. Se os primeiros ainda acreditavam no universo moderno, puro e ordenado, os outros aceitam o hedonismo pós-moderno e o caos metropolitano como ponto de partida para o seu trabalho. A relação entre as duas gerações acontece principalmente pela intenção de desenvolver uma atitude de vanguarda, pela a confiança no predomínio do mecanismo da "sintaxe" formal, por uma arquitetura caracterizada por construções dinâmicas, fragmentada, marcada pelo agrupamento e dedução de volumes.

No caso do OMA - Office for Metropolitan Architecture - sua principal referência arquitetônica são as propostas dos construtivistas soviéticos. Seus projetos buscam a reinterpretação das propostas do Movimento Moderno, porém sem a pretensão de recuperar a ordem ou os critérios racionais da cidade. Em seus projetos, fica evidente a influência das estruturas modernas, o ecletismo e o caos das metrópoles, as possibilidades das propostas das vanguardas.

Uma das grandes contribuições desta corrente é sua forte capacidade de renovar a representação arquitetônica, insistindo na ruptura do sistema clássico e dando continuidade às descobertas das vanguardas - cubismo, De Stijl, suprematismo, construtivismo - através da pesquisa das possibilidades de novas formas de representação: perspectivas com plantas e fachadas simultâneas, cortes rebatidos, perspectivas superpostas com cortes, colagem e, sobretudo, maquetes.

Esta arquitetura da nova abstração também buscou fontes de legitimização em outras disciplinas. Além da influência do pensamento pósestruturalista, da narração literária e das vanguardas das artes plásticas, é 
clara a influência das teorias matemáticas em Daniel Libeskind e Zaha Hadid ou da narração cinematográfica em Bernard Tschumi e Rem Koolhaas.

Contudo, alguns arquitetos ligados a esta corrente se distanciaram do rigor inovador das propostas iniciais e caíram numa maneirismo próprio, marcado pelo formalidade arbitrária, esquecendo as características básicas da própria arquitetura. Com isso, uma parte da produção arquitetônica relacionada com esta corrente foi alvo de duras críticas ao longo dos anos, evidenciando alguns perigos desta tendência: o formalismo, que boicota qualquer crítica racional; o elitismo que acredita que a realidade das grandes metrópoles capitalistas é a que vive toda a humanidade; a arbitrariedade da arquitetura concebida por ela mesma, ou seja, a arte pela arte.

Por ser uma arquitetura caracterizada essencialmente por uma reflexão metodológica fria e científica, na qual o que predomina é insistência do processo, os melhores exemplos desta arquitetura são observados em concursos ou projetos de edifícios singulares - nos quais os arquitetos tem a possibilidade de desenvolver plenamente suas teorias e conceitos, sem grande interferência por parte do cliente. No caso da tipologia residencial, muitas vezes o proprietário participa ativamente do processo e decisões de projeto. Por este motivo, a nova abstração formal pode ser observada como influência em algumas das residências analisadas, mas apenas como uma influência parcial, associada a outras correntes de pensamento.

\section{f) A saída pela alta tecnologia}

A tendência arquitetônica contemporânea que se baseia nas contribuições da ciência, da indústria e da técnica, pode ser considerada uma das mais representativas da arquitetura atual. É uma linha de pensamento que tem uma relação muito próxima com o Movimento Moderno, compartilhando alguns dos princípios básicos das vanguardas do início do século, especialmente o papel central outorgado a tecnologia como fonte de inspiração. É uma arquitetura baseada na confiança da capacidade de síntese da tecnologia, buscando resolver o máximo de questões com o mínimo de formas. 
Ao longo da história, observa-se que boa parte da arquitetura se desenvolveu a partir das possibilidades formais da utilização de novos materiais e tecnologias. Nos anos 60, destacam-se as utopias tecnológicas dos projetos do grupo britânico Archigram e dos japoneses do Metabolismo. Nos anos 80 , observa-se o retorno dessa confiança na racionalidade e na capacidade de síntese que o mundo da tecnologia pretende possuir intrinsecamente.

Dentro desta tendência, encontram-se posturas muito diferentes entre si. Em alguns casos, encontra-se uma arquitetura de alta tecnologia que busca uma grande elegância no desenho, como no caso da obra de Norman Foster. Em outras situações, predomina a agressividade e presença de elementos estruturais e de instalações, como por exemplo, na sede da Companhia Lloyd em Londres, obra de Richard Rogers. Na arquitetura de Jean Nouvel, a linguagem tecnológica abandona a condicionante da estrita racionalidade e explorar campos formais baseados na evocação ou na proximidade a outras artes. Já nas obras de Santiago Calatrava, a tecnologia se desdobra em formas escultóricas e expressivas. E ainda exemplos como o escritório suíço Herzog \& de Meuron, nos quais a monumentalidade, quase sempre associada ao uso da alta tecnologia, é substituída pela busca de uma saída renovadora na qual o estatuto material de cada obra seja essencial.

Em resposta as críticas lançadas por parte do pensamento contemporâneo - especialmente ecologistas e defensores do pós-modernismo - contra o poder totalitário e destrutivo da tecnologia, na última década a arquitetura tecnológica buscou se adaptar ao contexto urbano onde se insere particularmente as condicionantes naturais. Alguns dos representantes mais significativos desta linha de pensamento - como, por exemplo, o arquiteto Richard Rogers - defende a utilização dos avanços tecnológicos em prol de uma arquitetura ecológica, sustentável, respeitando o meio ambiente.

É possível observar grande influência da arquitetura tecnológica em Curitiba, particularmente em edifícios de escritório, obras comerciais e institucionais. Algumas das residências selecionadas para este trabalho evidenciam a influência desta linha de pensamento, em particular a residência 
da arquiteta Daniela Busarello. Neste caso específico, a arquiteta coloca a escolha da tecnologia construtiva como ponto de partida para a concepção do projeto. No caso da residência do escritório Átrio Arquitetura, a afinidade com a arquitetura tecnológica ocorre através da evidência de elementos estruturais e de instalação, como por exemplo, as chaminés da lareira e churrasqueira e a estrutura de concreto aparente.

\section{g) Minimalismo}

Em resposta tanto aos exageros simbólicos e decorativos da arquitetura eclética e pós-moderna, como do intelectualismo, elitismo e formalismo vazio de certas arquitetura da nova abstração formal, o minimalismo propões uma linha de pensamento voltada para a recuperação da poética da simplicidade, do silêncio, do contextualismo. Diante da superabundância e da dúvida, opta-se pelo mínimo, pela concepção de espaços diretos e puros, pela utilização de formas simples, pela busca de um sentido comum tectônico presente no uso rigoroso e asséptico dos materiais.

A arquitetura minimalista procura utilizar um número de elementos, materiais e linguagens limitadas, articulados de forma essencial, buscando a qualidade material e tectônica de cada obra. Tem como referência o conceito "Less is more" de Mies van der Rohe, contudo sem a pretensão de universalidade, e sim de relação com as variáveis oferecidas pelo lugar.

Nesta linha de pensamento, Tadao Ando destaca-se por uma obra sutil e silenciosa, que contrasta com o comercialismo da arquitetura e do urbanismo do Japão atual. Sua obra é marcada pelo uso do concreto aparente e pela busca da abstração formal e simbólica baseada na simplicidade volumétrica, importância dada à luz natural e na sobriedade monasterial. $\mathrm{O}$ arquiteto define uma nova tradição moderna, influenciada pela arquitetura de Mies van der Rohe, Le Corbusier e Kenzo Tange, mas que também procura a relação com o contexto natural e a reinterpretação dos valores históricos e culturais locais. Seus projetos recriam um espaço essencial, onde se encontram tradição japonesa e contemporaneidade. 
Na Europa, um dos arquitetos mais representativos desta tendência é o português Eduardo Souto de Moura. Já no Brasil, Paulo Mendes da Rocha realizou obras emblemáticas como o Museu de Escultura de São Paulo. Embora influenciada por outras linhas de pensamento, pode-se observar algumas características da arquitetura minimalista nos projetos do Studio Bertoldi e Daniela Busarello, que serão analisados nos próximos capítulos.

\section{h) Arquitetura ecológica}

Durante os anos 90, a conscientização em relação à necessidade de preservação do meio ambiente e uso racional das fontes de energia teve papel central nas discussões sobre arquitetura. Desta forma, pode ser observado o ressurgimento da sensibilidade para as chamadas arquiteturas ecológicas, preocupadas com a economia de materiais e energia, e também com a integração com o entorno.

Destacam-se obras que recorrem às formas e tipos mais facilmente adaptáveis ao meio e com mais capacidade para relacionar-se com as energias do entorno: galerias exteriores, pátios internos, peles permeáveis, edifícios em forma de estufas, formas escalonadas que buscam o aproveitamento da energia solar, edifícios semienterrados e estrutura leves e recicláveis.

Se a completa adaptação ao entorno e contexto existentes, associada à utilização quase exclusiva de tecnologias e materiais locais ainda não é uma alternativa muito usual - embora as residências projetadas pela arquiteta Andrea Berriel e a reciclagem de um antigo moinho proposta por Gustavo Pinto sejam exemplos emblemáticos desta linha de pensamento na arquitetura de Curitiba - a preocupação na adequação ambiental do projeto, aproveitamento da insolação e ventos dominantes e respeito às características topográficas originais do sítio está presente em praticamente todas as obras analisadas nesse trabalho.

A partir dos anos 2000, o debate em torno da ecologia, a utilização consciente de recursos materiais e energéticos, a preocupação com o conforto ambiental das edificações, de certa forma influenciou todas as correntes da 
arquitetura atual. Embora o termo "arquitetura ecológica" seja mais adequado no caso específico de obras que outorgam papel central as questões ambientais no desenvolvimento do projeto, observa-se que estas questões se tornaram parte essencial no questionamento e desenvolvimento da maioria das obras arquitetônicos contemporâneas.

Além da classificação utilizada neste trabalho, proposta por Josep Maria Montaner, outros teóricos também propuseram formulações essenciais, como por exemplo, Kenneth Frampton e Charles Jencks. Esta diversidade de pontos de vista sobre a atualidade evidencia a sua pluralidade, deixando espaço para diferentes interpretações e propostas de classificação desta nova arquitetura. Este estudo procurou se basear nestas formulações e sintetizar as principais linhas de pensamento, da forma mais coerente, para a análise do panorama da arquitetura atual.

Neste aspecto, ainda é importante ressaltar que este trabalho não tem a pretensão de delimitar a postura de cada arquiteto a uma única corrente de pensamento. Como se observa no panorama atual da arquitetura internacional, os arquitetos mais representativos apresentam uma visão mais híbrida, na qual se conciliam diversos conceitos. Rem Koolhaas, Álvaro Siza, Jean Nouvel, Renzo Piano, Herzog \& de Meuron, entre outros, não podem ser explicados através de ideias estritas e únicas, senão como síntese evolutiva de várias tendências: minimalismo, comunicação, pós-modernismo, sustentabilidade, tecnologia, figuração, tudo isso assumido ao mesmo tempo.

Da mesma forma, não se pretende engessar a análise dos projetos selecionados a uma única e exclusiva corrente arquitetônica, e sim identificar influências e tendências no posicionamento na arquitetura atual de Curitiba.

\section{A SELEÇÃo dOS PROJETOS}

\subsection{A arquitetura de Curitiba na visão dos arquitetos}


Com o objetivo de identificar projetos e escritórios de arquitetura, relevantes para o contexto cultural da cidade e que pudessem representar a arquitetura de Curitiba dos anos 2000, foi realizada uma pesquisa com aproximadamente 70 profissionais, relacionados com a área. $\mathrm{O}$ intuito desta pesquisa era conhecer a opinião dos arquitetos curitibanos e compreender como estes veem a arquitetura da cidade. Entre os arquitetos selecionados, encontram-se profissionais atuantes no mercado, críticos de arquitetura de Curitiba, membros do IAB Paraná, IPHAN, IPPUC, Secretaria de Urbanismo do Estado, professores do corpo docente das cinco principais faculdades de arquitetura de Curitiba: Universidade Federal do Paraná (UFPR), Universidade Tecnológica Federal do Paraná (UTFPR), Pontifícia Universidade Católica do Paraná (PUC-PR), Universidades Positivo (UNICENP) e Faculdade Tuiuti do Paraná (FTP). Desta forma, essa seleção procurou ouvir não somente acadêmicos da disciplina, mas também profissionais ligados ao mercado e em contato direto com clientes.

A pesquisa realizada solicitou aos arquitetos que identificassem três escritórios de arquitetura, três obras e três residências unifamiliares construídas após o ano 2000 - que considerassem essenciais para compreender a arquitetura curitibana. Desta forma, seria possível identificar não somente as residências mais marcantes da cidade, mas também profissionais e obras consideradas relevantes para o panorama.

O primeiro aspecto marcante desta pesquisa foi o reduzido número de arquitetos que respondeu as três questões de forma completa. Menos de $20 \%$ dos entrevistados citaram três exemplos para cada uma das perguntas propostas na entrevista. A maioria dos entrevistados citou apenas uma ou duas casas, alegando não estar particularmente familiarizado com a arquitetura residencial da cidade no período citado.

Outro aspecto importante foi a constante presença de duas residências específicas entre as respostas: a primeira, a Residência Casagrande Bertoldi (também conhecida como Casa da Pedreira), de autoria do arquiteto Marcos Bertoldi, amplamente divulgada e estudada pelos principais periódicos e revistas de arquitetura. 
A outra residência citada por grande parte dos arquitetos foi a residência projetada pelo escritório paulista Una Arquitetos, concluída em 2004. Apesar de ter sido projetada por um escritório de fora, esta obra tem um papel importante no panorama da arquitetura da cidade. Representa o desejo de clientes de arquitetura - ou pelo menos parte deles - em fugir do padrão imobiliário e dar oportunidade para projetos que sejam reflexo de uma arquitetura nova, relacionada com seu tempo, local onde está inserida e as necessidades específicas de seus usuários.

Se até então parte dos arquitetos curitibanos responsabilizava o mercado ou os clientes pela falta de oportunidade para realizar projetos menos conservadores, a residência do Una veio provar que existia pelo menos uma parte da população estava disposta a realizar projetos com essas características.

Além disso, a repercussão desse projeto - não somente no meio arquitetônico, mas na sociedade em geral - fez com que as portas para uma nova arquitetura se abrissem em Curitiba. A residência se tornou símbolo do que havia de mais moderno na arquitetura residencial. A partir desta residência, clientes tornaram-se mais abertos e receptivos a ideias dos arquitetos relacionadas com correntes contemporâneas. Estes, por sua vez, precisavam demonstrar para a população que estavam aptos e preparados para atender a tais encomendas, e que não era necessário buscar escritórios de fora para conseguir tal resultado.

\subsection{A divulgação em jornais, revistas e periódicos}

A pesquisa em jornais, revistas e periódicos mostrou que, nas últimas décadas, o urbanismo de Curitiba obteve um espaço consideravelmente maior do que a arquitetura da cidade. As obras de arquitetura, divulgadas na década de 90 na mídia especializada, foram principalmente as obras públicas construídas pelo estado, com destaque para a Universidade Livre do Meio Ambiente, de Domingos Henrique Bongestabs, e para o Memorial dos 300 Anos, de Fernando Popp, Jaime Lerner e Valéria Bechara. O uso de troncos de 
madeira tornou-se uma característica dos projetos da SEMMA (Secretaria de Meio Ambiente) e posteriormente de outros setores da Prefeitura de Curitiba, até se consolidar como uma característica própria da arquitetura Pública do Paraná dos ano 90.

Além desta arquitetura pública, alguns escritórios consolidados há décadas na cidade - que se destacaram durante o auge da arquitetura curitibana nas décadas de 60 e 70 e continuaram realizando bons projetos nas décadas seguintes - também foram mencionados em publicações de âmbito nacional.

Especialmente durante a década de 90, escritórios liderados por arquitetos como Alfred Willer, José Sanchotene, Manoel Coelho, que pelo tempo de atuação e qualidade das obras delinearam boa parte do que existe de mais interessante na arquitetura da cidade, voltaram a ter espaço em publicações especializadas.

Já na década de 2000, o arquiteto Marcos Bertoldi foi mencionado em livros sobre arquitetura contemporânea no Brasil, como exemplo Casa Modernista: A History of the Brazil Modern House, livro dedicado ao estudo de casas influentes da arquitetura brasileira da década de 20 até os anos 2000 . As casas de Bertoldi foram tema de matérias de revistas brasileiras - entre elas, a Projeto Design de dezembro de 2006 - e também, revistas internacionais, como a americana Architectural Digest e a alemã MD Moebel Interior Design.

$\mathrm{O}$ arquiteto Manoel Coelho teve diversos de seus projetos para $\mathrm{O}$ campus da Universidade Positivo publicados nas principais revistas de arquitetura do Brasil e algumas publicações no exterior. Entretanto, há alguns anos o escritório deixou de realizar projetos para residências unifamiliares, não se enquadrando nesta pesquisa. O escritório Átrio Arquitetura, também, teve um de seus projetos - a academia de ginástica e natação Gustavo Borges divulgado em uma edição da Projeto Design, em outubro de 2002.

\subsection{A participação em concursos e premiações}


Para analisar a participação dos arquitetos curitibanos em concursos, foi feito um levantamento dos principais concursos regionais e nacionais realizados entre 2001 e 2010. Foram levantados os resultados de 62 concursos, incluindo primeiro, segundo, terceiro colocados e menções honrosas.

Através dos resultados desta pesquisa, pode-se observar que alguns arquitetos curitibanos tiveram participação ativa nos concursos nacionais, especialmente a partir de 2003. Entre estes, destaca-se a equipe do arquiteto Emerson Vidigal, vencedora dos dois concursos para a Sede do CREA no interior do Paraná - nas cidades de Apucarana e Maringá, em 2003 - e da Sede da Procuradoria Regional da República, em Porto Alegre.

Outras três equipes curitibanas que apareceram diversas vezes entre os três primeiros colocados: a equipe formada por parte dos integrantes do escritório de arquitetura Central de Projetos; a equipe dos arquitetos Igor Costa Spanger, Leandro Coradin, Pedro Pereira Júnior; a equipe dos arquitetos Eron Danilo Costin, Dario Corrêa Durce, Rodrigo Martins.

Escritórios curitibanos também apareceram na lista de premiados da AsBEA - Associação Brasileira de Escritórios de Arquitetura. São estes: Willer Arquitetos Associados (2002 e 2004); Dória Lopes Fiúza Arquitetura (2003 e 2004); Studio Bertoldi (2004 e 2006).

\subsection{Escolha final das obras}

A seleção final das residências a serem estudadas neste trabalho foi realizada a partir da análise das informações obtidas nas três etapas de coleta de material, descritas anteriormente, e na avaliação da disponibilidade dos arquitetos e proprietários das obras em fornecerem material e se disponibilizarem a colaborar com esta pesquisa.

A casa do Studio Bertoldi escolhida para análise foi o projeto com maior número de menções na entrevista com arquitetos da cidade. Outra obra marcante na opinião dos arquitetos entrevistados é a residência projetada pelo 
escritório paulista Una, pela sua originalidade e influência sobre outras obras construídas em Curitiba.

Além destas duas residências, a seleção de projetos foi feita com o intuito de delinear um panorama geral da arquitetura, sem prender-se muito a um único grupo de arquitetos ou estilo. Desta forma, mostrou-se essencial a análise da residência projetada pela arquiteta Andrea Berriel, uma obra que explora uma linguagem arquitetônica claramente contemporânea, através do uso da tecnologia em madeira e materiais locais. Da mesma forma, fez-se necessário incluir na análise o projeto do arquiteto Gustavo Pinto, um notável exemplo de reciclagem de um antigo moinho para uso residencial.

Entre as demais obras selecionadas, houve a preocupação de mostrar obras de arquitetos de diferentes gerações. Desde escritórios estabelecidos há décadas em Curitiba - como o Z Arquitetura (Slomp Busarello), responsável por diversos edifícios comerciais e residenciais que pontuam o skyline da cidade - até escritórios recentes, com intensa participação em concursos e menor número de obras construídas, como o caso do Central de Projetos. 


\section{UNA ARQUITETOS: RESIDÊNCIA EM CURITIBA}

Condomínio Vila de Molino - Parque Tingui

Curitiba, Paraná

Arquitetos: Cristiane Muniz, Fábio Valentim, Fernanda Barbara e Fernando Viégas

Colaboradores: Apoena Amaral, Boris Koischwitz, Clóvis Cunha, Felipe Noto, Eduardo Baravelli, Márcio Wanderley, Nicholas Brennand e Sabrina Lapyda Projeto: 2002

Conclusão: 2005

Estrutura de Concreto: Eng. Eduardo Duprat

Construção: Marcos Marcolla

Área: $313,60 \mathrm{~m} 2$

Área do terreno: 892,55 m2

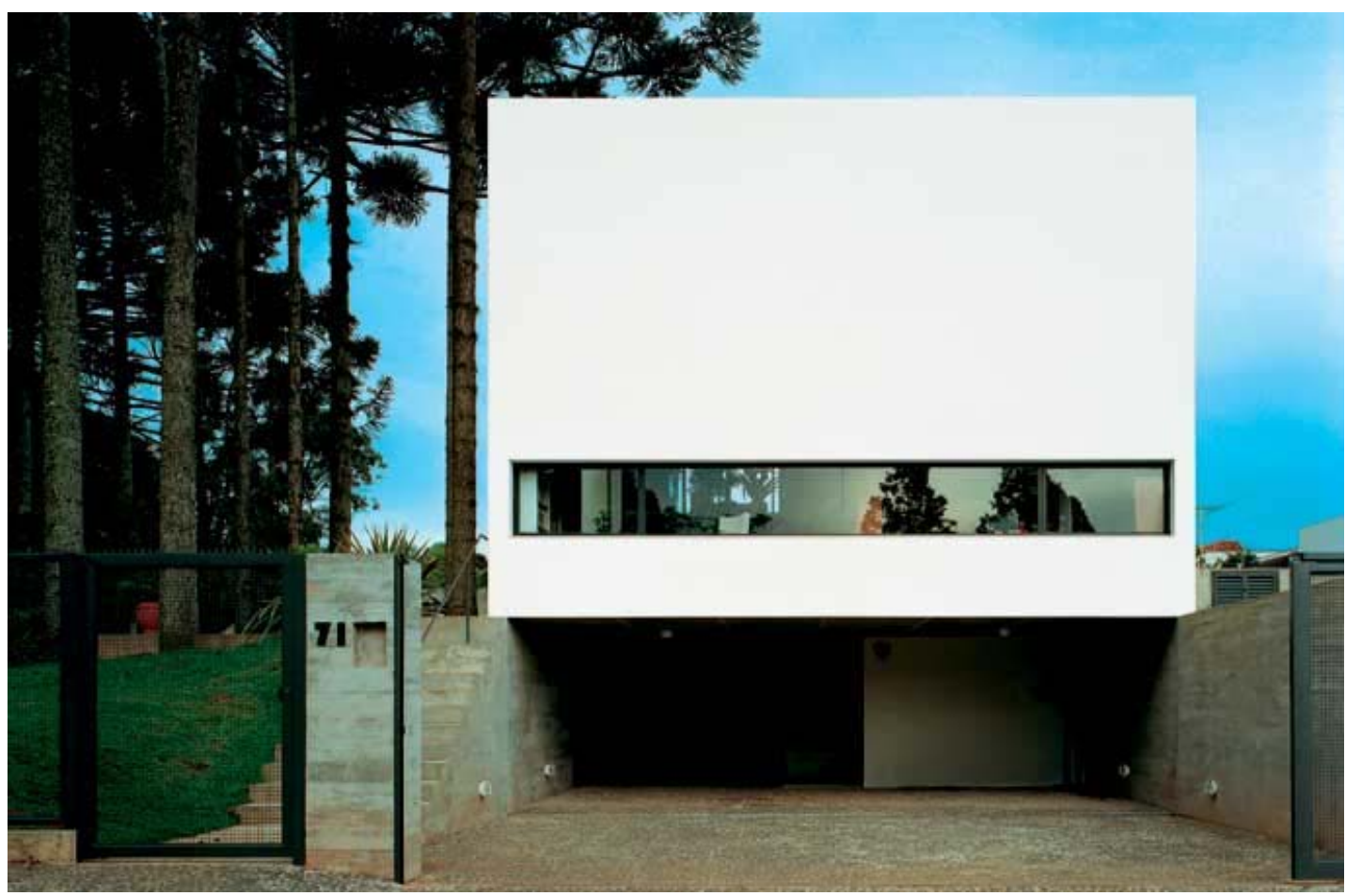

Figura 28 - Residência UNA em Curitiba: elevação frontal 


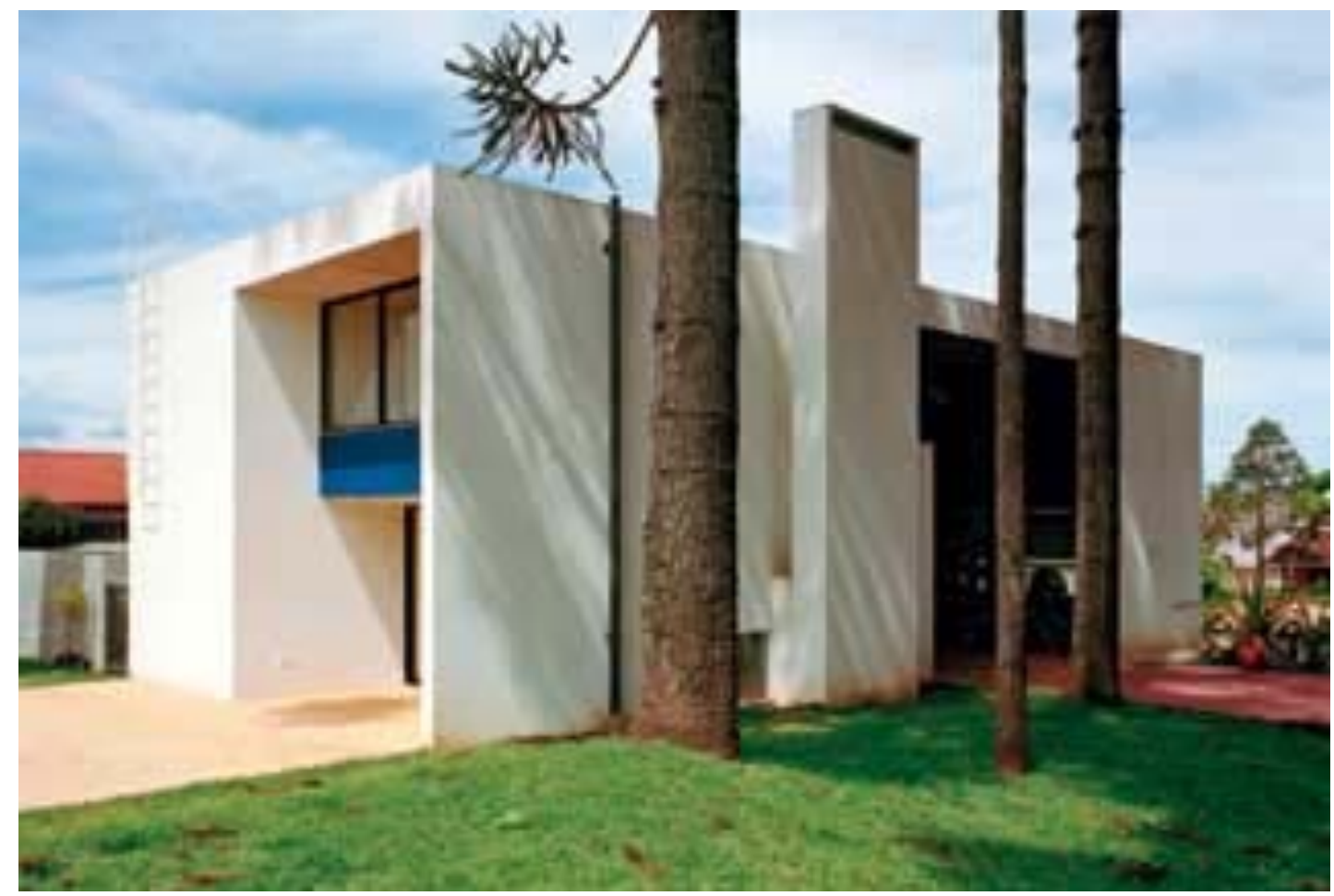

Figura 29 - Residência UNA em Curitiba: perspectiva fundos

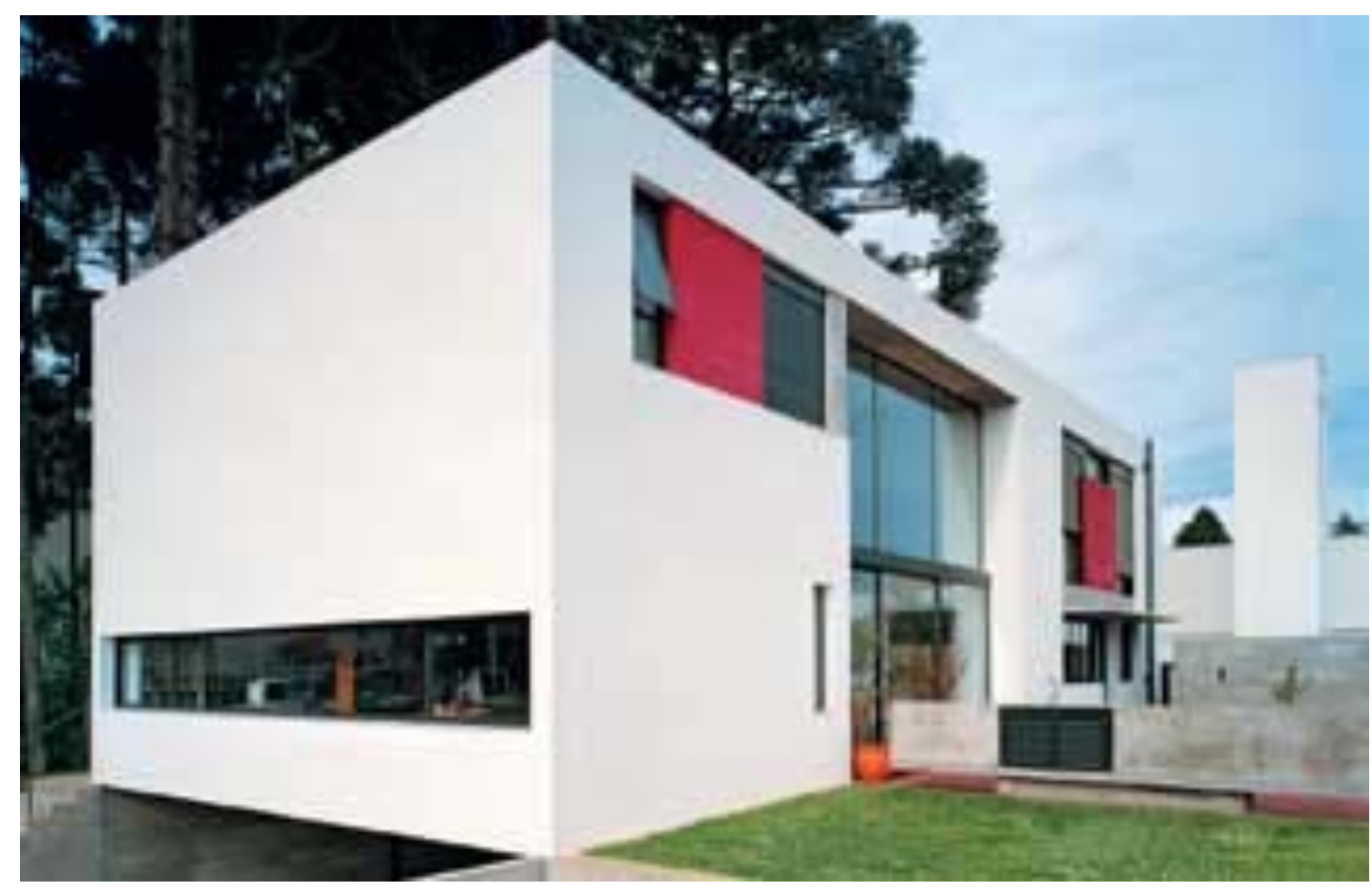

Figura 30 - Residência UNA em Curitiba: perspectiva frontal 


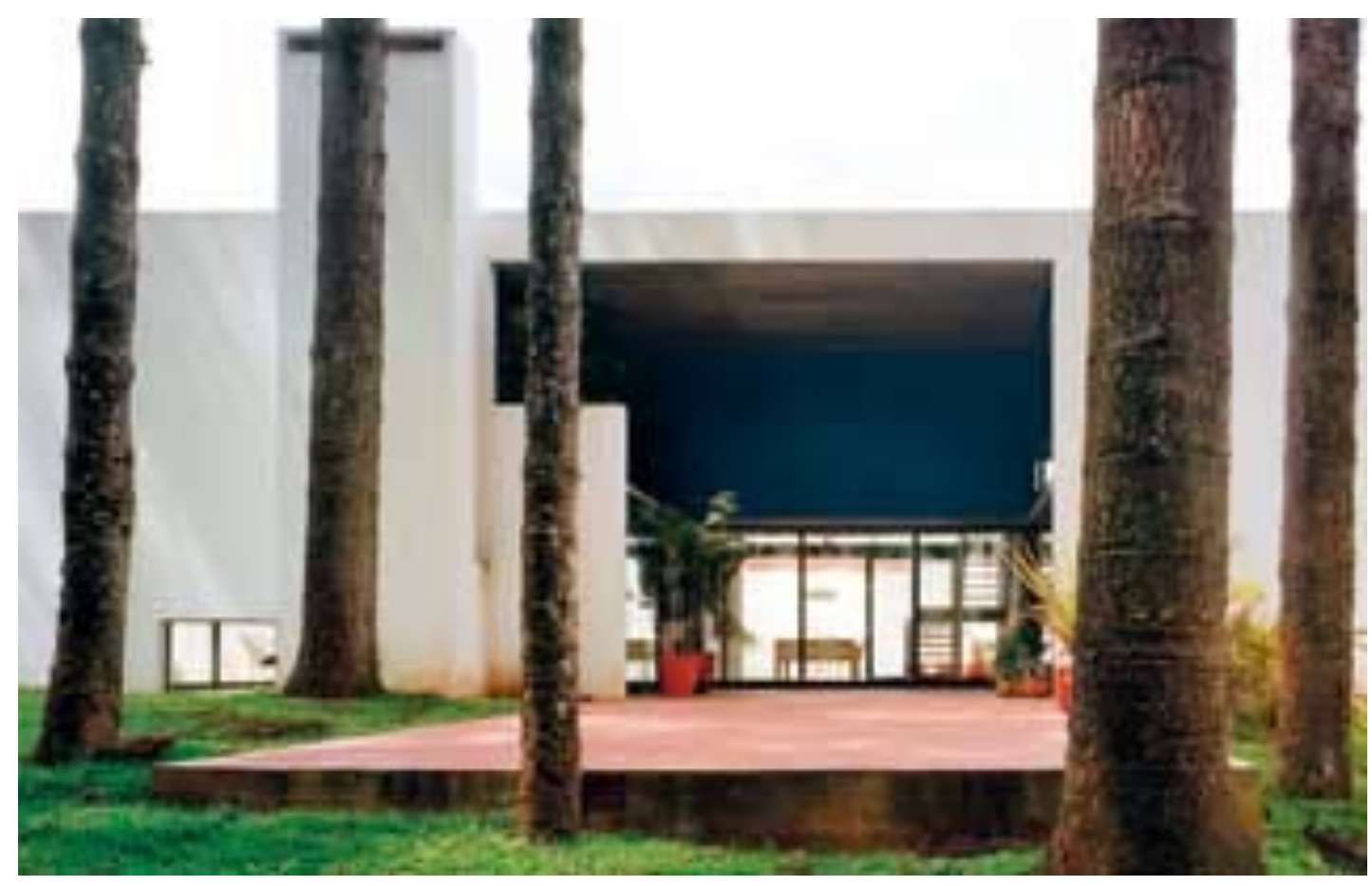

Figura 31 - Residência UNA em Curitiba: vista lateral

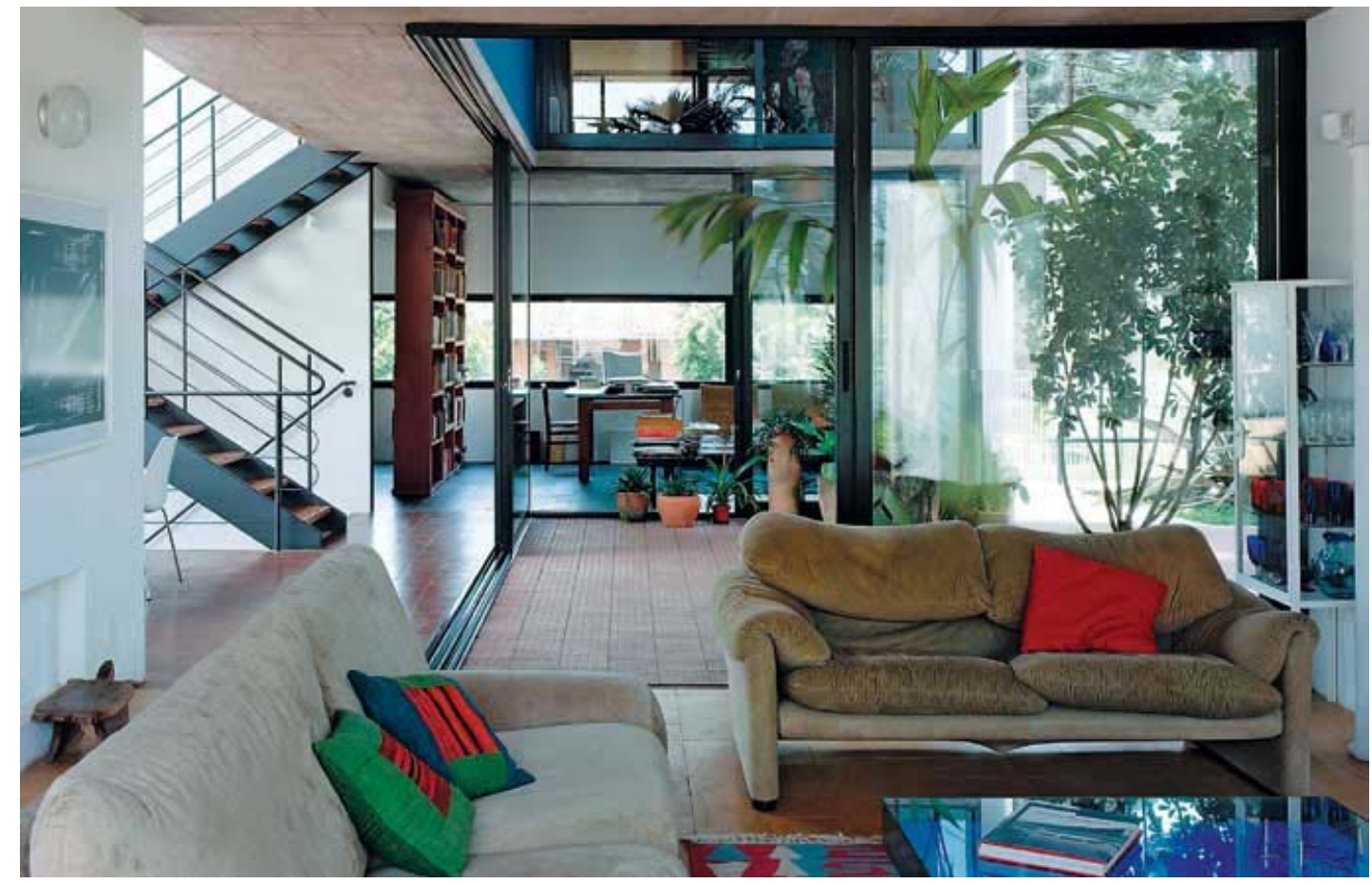

Figura 32 - Residência UNA em Curitiba: interior 


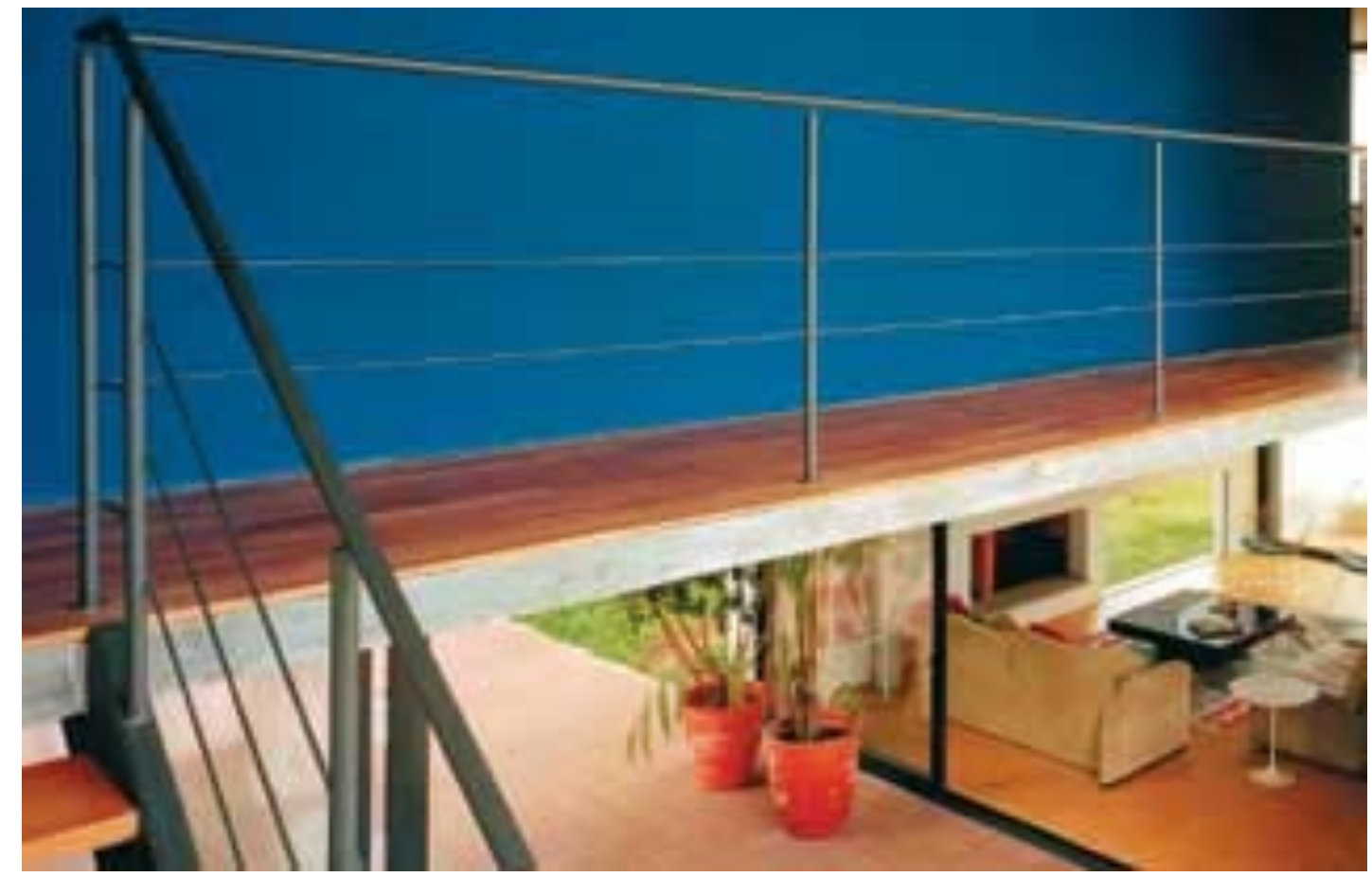

Figura 33 - Residência UNA em Curitiba: detalhe guarda-corpo

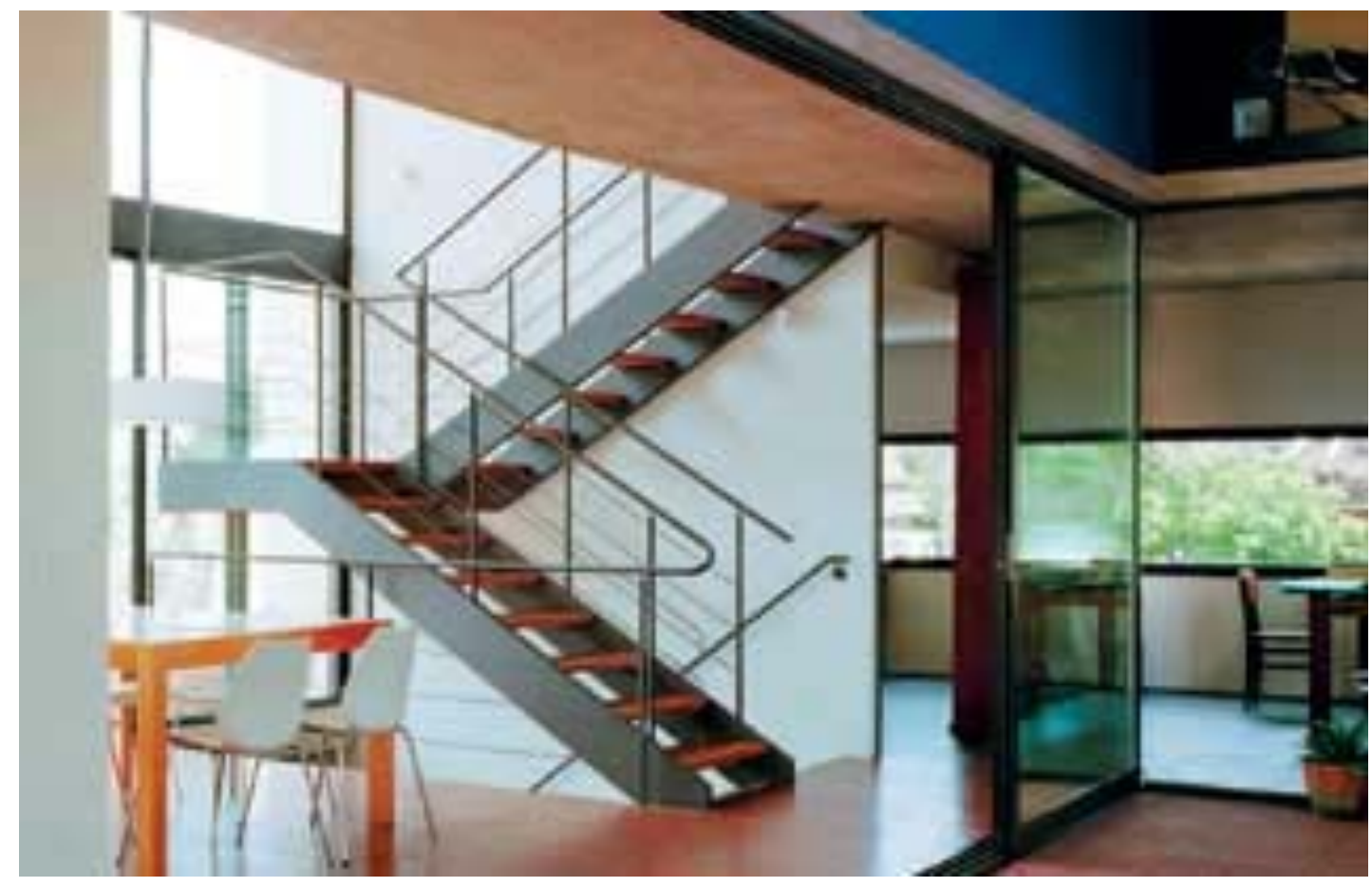

Figura 34 - Residência UNA em Curitiba: escada 


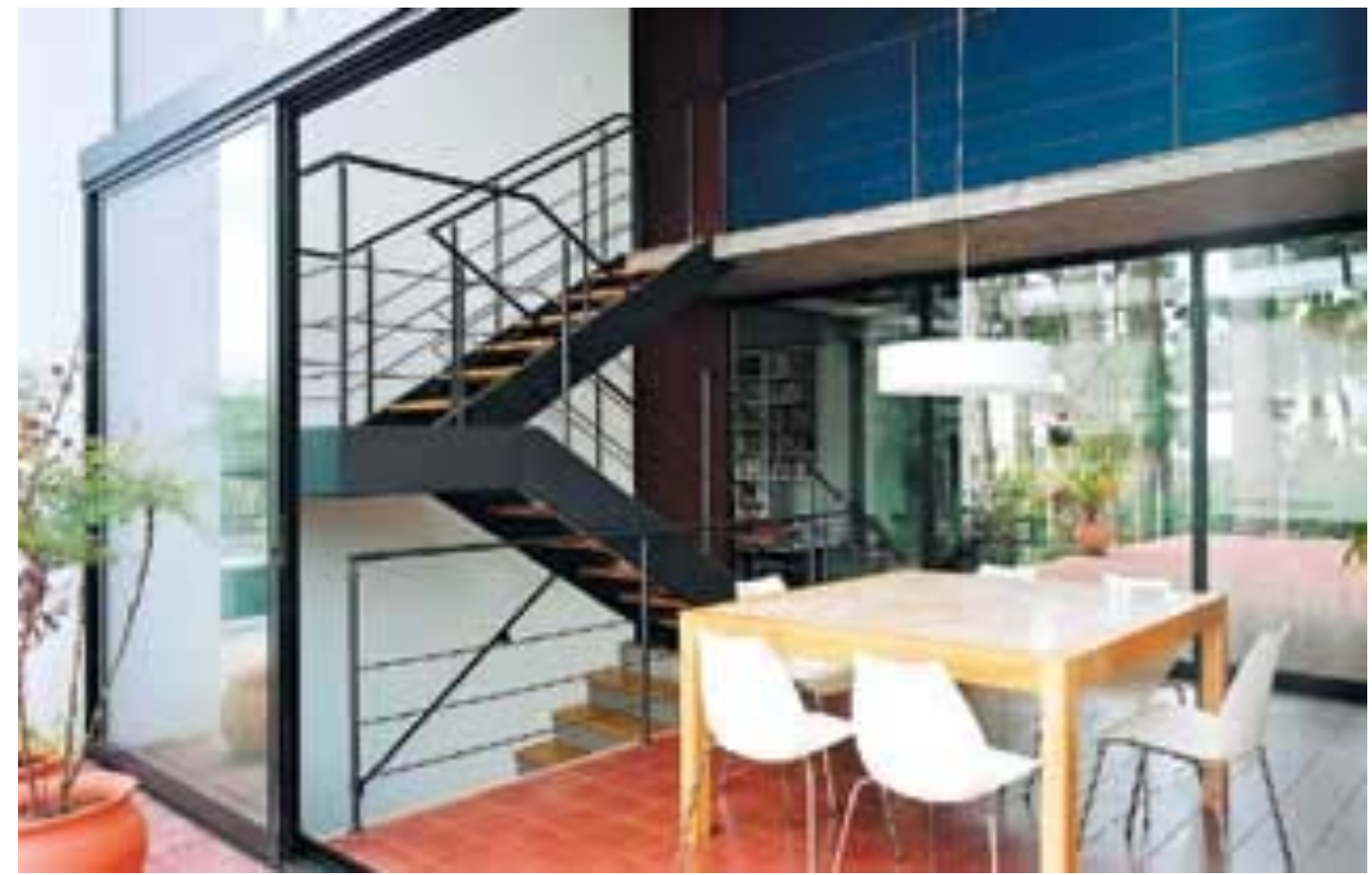

Figura 35 - Residência UNA em Curitiba: sala de jantar

Pavimento inferior

1. Garagem

2. Hóspedes

3. Pátio

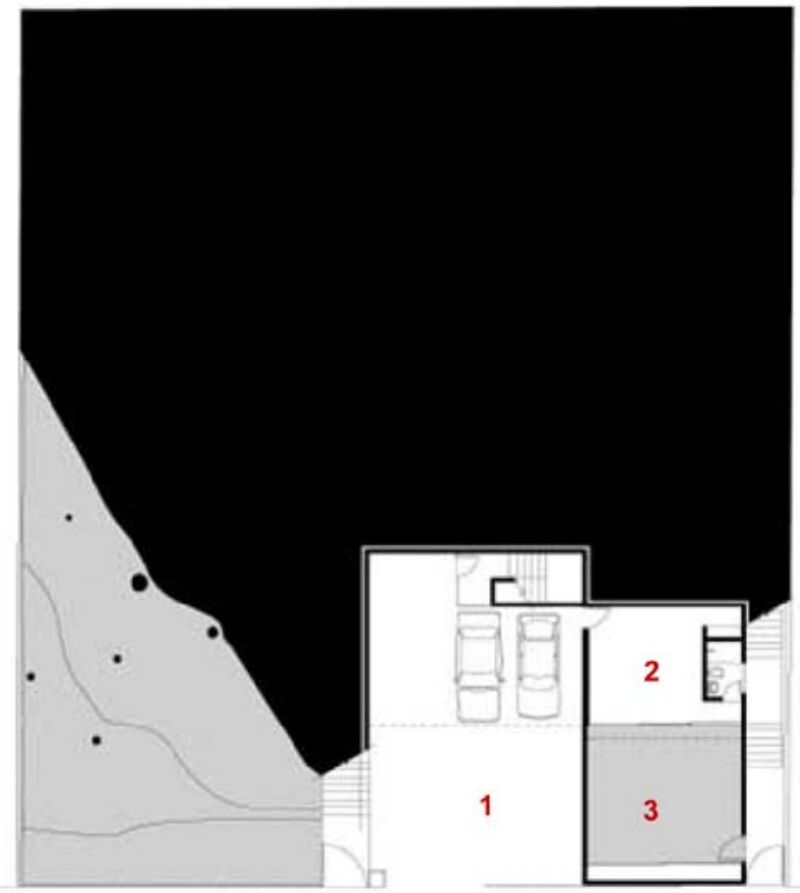

Figura 36 - Residência UNA em Curitiba: planta pavimento inferior 
Térreo

1. Pátio descoberto

2. Varanda

3. Jantar

4. Escritório

5. Churrasqueira

6. Estar

7. Caixa-d'água

8. Pátio de serviço

9. Cozinha

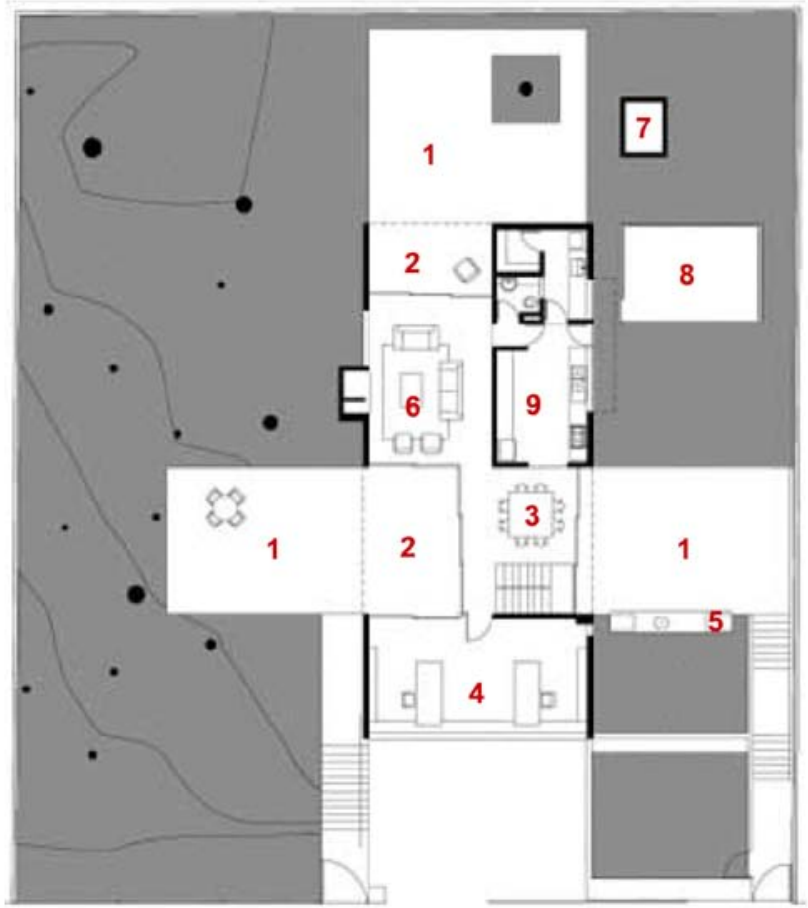

Figura 37 - Residência UNA em Curitiba: planta pavimento térreo

Pavimento superior

1. Passarela

2. Suite

3. Estar

4. Dormitório

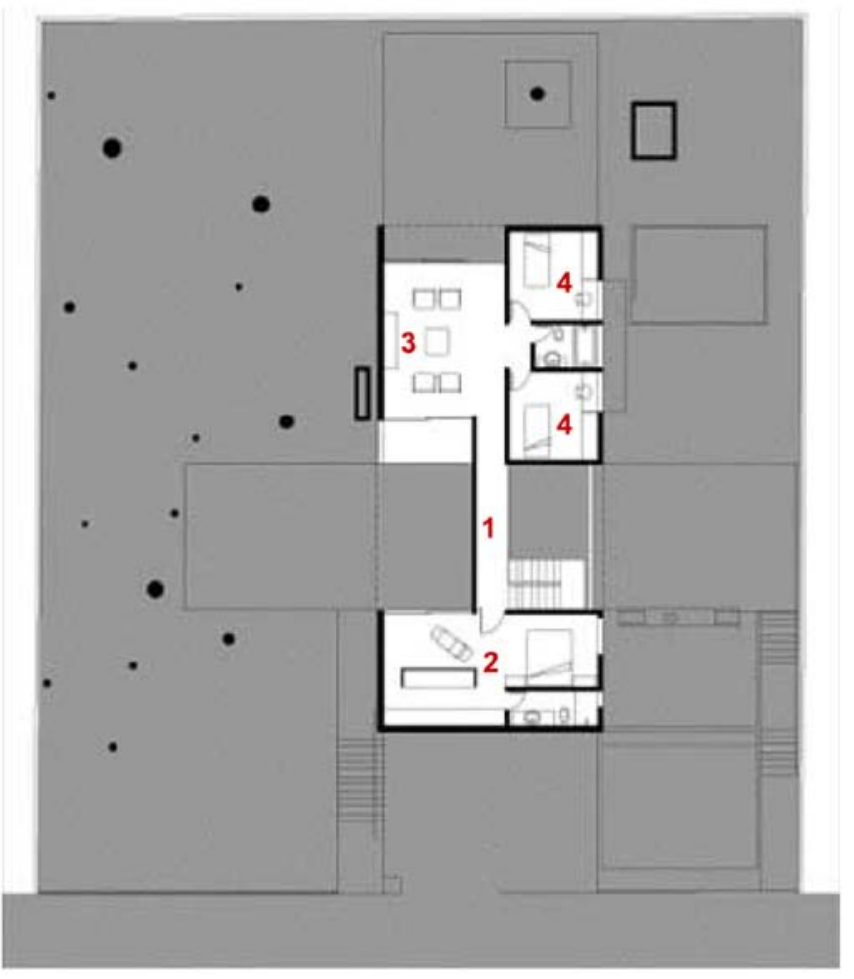

Figura 38 - Residência UNA em Curitiba: planta pavimento superior 


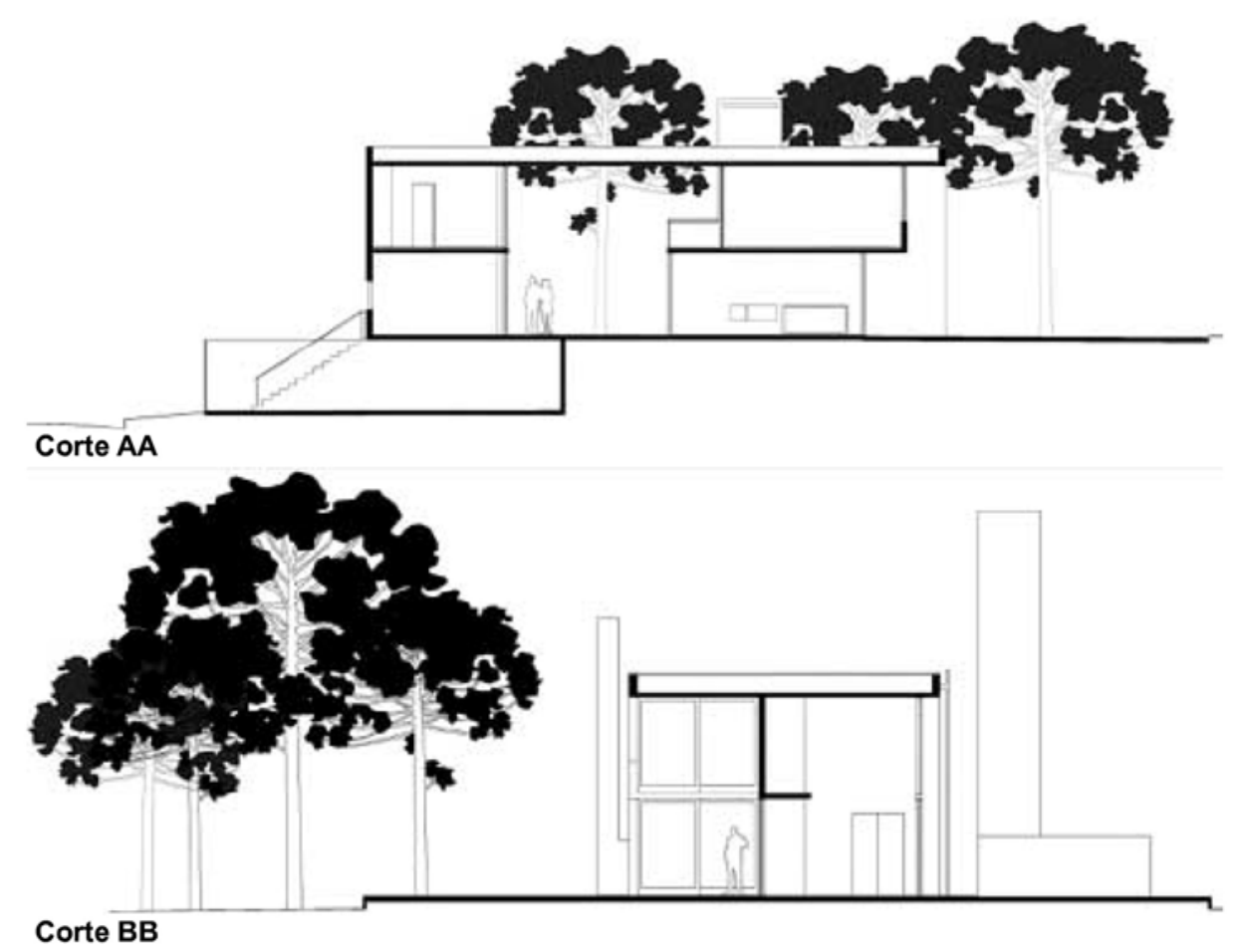

Figura 39 - Residência UNA em Curitiba: cortes

\subsection{Visão geral}

Concluída no ano de 2005, a residência projetada pelo escritório paulista UNA é um marco essencial no panorama arquitetônico de Curitiba. Em pouco tempo, a obra tornou-se conhecida na cidade e ganhou espaço em revistas e sites especializados.

Ao lado do escritório de advocacia projetado pelo também paulista Mario Biselli, em 1998, e de alguns poucos exemplos até então projetados em Curitiba, o projeto do UNA mostrava uma nova realidade: a existência de um mercado para uma arquitetura contemporânea, de linhas retas, na cidade até então marcada pelos elementos de origem neoclássica; e a possibilidade de fugir dos esquematismos imobiliários. Esquematismos que durante a década de 90 trouxeram uma má reputação e empobreceram o skyline de Curitiba: edifícios com fachadas decorativistas, vazios de conceitos e carentes em qualidade, pastiche de uma época marcada por símbolos de fácil reconhecimento e aceitação da população - mas que, em sua releitura 
curitibana, resumiam-se em adornos vazios de significado, escondendo estrutura e revestimentos de baixa qualidade.

A grande repercussão desta residência na mídia influenciou a visão da população curitibana em relação a projetos com traços e características contemporâneas. Se antes estes projetos causavam certo estranhamento na maior parte da população, agora eram vistos com olhos mais receptivos, facilitando a margem de ação dos arquitetos de Curitiba, comprometidos com a boa arquitetura.

\subsection{Implantação e relação com o entorno}

O terreno é ocupado por uma mata de araucárias que se estende até os lotes vizinhos. Com o objetivo de preservar estas árvores, os arquitetos optaram por construir a obra na cota mais alta do lote, minimizando a intervenção na topografia e vegetação original.

O volume de três pavimentos se assenta longitudinalmente no terreno, delimitando duas áreas externas laterais - de um lado, um espaço de convivência, e do outro, o bosque com araucárias. Estes ambientes se relacionam através de um pátio de pé-direito duplo, determinando o que a arquiteta Fernanda Bárbara chamou de "uma relação mediada com o exterior".

Cercado por portas de correr envidraçadas que delimitam um espaço em forma de "U", o pátio pode ser incorporado tanto às áreas de lazer e jantar da casa quanto ao jardim externo. Essa característica do pátio dilui a fronteira exterior/interior da casa e reforça a relação da obra com o entorno.

\subsection{Programa de atividades}

A residência foi projetada para um casal com dois filhos. Os proprietários solicitaram a inclusão de um quarto de hóspedes e de um escritório/biblioteca no programa. 
A implantação na cota mais alta do terreno em aclive resultou num pavimento no nível da rua apenas com o acesso, garagem, quarto de hóspedes e pátio interno.

No nível acima, distribuem-se as salas de jantar, estar, escritório sendo que estes três ambientes podem conectar-se entre si pelas portas de correr envidraçadas do pátio - cozinha, área de serviço e churrasqueira, além de varandas e áreas externas voltadas para os jardins.

No último pavimento, encontra-se a suíte do casal, estar íntimo e as duas demi-suítes. A conexão entre a suíte e os outros ambientes é feita através de uma passarela que atravessa o pátio interno da casa, conferindo maior privacidade a suíte do casal.

\subsection{Partido arquitetônico}

O projeto buscou tirar partido das araucárias existentes no lote. A presença destas árvores determinou a relação da obra com o entorno, a verticalidade do projeto e a opção por uma planta concisa, disposta longitudinalmente no centro do terreno.

O pátio interno com portas de correr envidraçadas que possibilita a abertura e continuidade entre residência e jardins é determinante no projeto. É devido a sua existência que a obra assume o partido de relação controlada com o meio, e é através dele que ocorre toda a iluminação e ventilação natural.

Esta área de transição faz com que a residência tenha um ambiente agradável e a iluminação natural abundante traz a sensação de conforto às áreas ligadas ao pátio. No pavimento superior, a passarela favorece 0 zoneamento das áreas íntimas. Os quartos de solteiro ganham um espaço de convívio reservado no estar íntimo/varanda que se abre para os fundos do lote, enquanto a suíte do casal ganha privacidade no outro extremo do bloco. Apesar de estar localizada na elevação frontal, a suíte é silenciosa e intimista, devido à parede cega e de aspecto minimalista que isola o cômodo da rua e as aberturas generosas voltadas para o jardim. 


\subsection{Sistema construtivo}

No nível da rua, uma parede de concreto apoia a residência e delimita a área do pavimento térreo. $O$ bloco, também em concreto, de dois pavimentos assentado na cota mais alta do lote, é marcado pela ortogonalidade e dimensão generosa do pé-direito duplo. Seu exterior, pintado na cor branca, contrasta com os painéis cegos pintados de vermelho em algumas aberturas da fachada dos quartos e com a parede azul da passarela do andar superior.

O bloco de concreto é recortado por aberturas que assumem configurações pouco usuais e conferem plasticidade a obra. $\mathrm{Na}$ elevação frontal, um rasgo horizontal da biblioteca marca a elevação voltada para a rua e se estende por todo o comprimento da fachada.

$\mathrm{Na}$ lateral do bosque das araucárias, os caixilhos das portas de correr do pátio interno invadem a construção criando uma grande abertura no bloco principal. O piso desta área é uma faixa de ladrilho hidráulico transversal à construção, reforçando a ligação entre as duas áreas externas. As lajes internas não possuem forro, são em concreto aparente. A cobertura é em laje impermeabilizada.

\subsection{Intenção Plástica}

O volume branco e ortogonal da residência procura condensar em uma posição mais ou menos central do terreno as atividades do programa. Com isso, libera uma grande área de jardim nas duas laterais da casa, com a quais esta se relaciona de forma amistosa.

O bosque de araucárias, adjacente a construção, leva os arquitetos a buscar certa verticalidade na obra, mas sem dúvida esta proporção também foi criada para garantir a harmonia das dimensões. As proporções são semelhantes as da residência João Luís Bettega, projetada por Artigas, e também tem em comum com esta obra a organização de todos os ambientes da residência em um único volume.

O bloco principal está apoiado em um plano de concreto, configurandose como uma paralelepípedo perfeito, com superfícies pintadas na cor branco. 
Uma subtração na fachada lateral dá origem ao pátio - ambiente essencial da casa e conexão desta com o entorno. Na fachada oposta, grandes vãos interligam as aberturas dos quartos, banheiros e cozinha. Essas aberturas são interrompidas por painéis cegos de cor vermelha, controlando as visibilidade da área externa para o interior da casa, com o objetivo de manter a privacidade nas áreas mais íntimas.

$\mathrm{Na}$ elevação frontal, o recuo da parede de concreto que sustenta o bloco passa a impressão de que este está flutuando, dando uma sensação de leveza à residência.

Alguns aspectos da obra deixam transparecer a influência das vanguardas do início do século, como por exemplo, o uso de cores primárias em detalhes do projeto contrastando com o volume branco. O rasgo horizontal do escritório na fachada voltada para a rua remete as janelas em fita das casas modernistas. A pureza dos volumes e o aspecto tectônico da obra evidenciam certa influência da arquitetura minimalista. 


\section{STUDIO BERTOLDI: CASA DA PEDREIRA (CASAGRANDE BERTOLDI)}

Condomínio Vila de Molino - Parque Tingui

Curitiba, Paraná

Arquitetos: Marcos Bertoldi

Colaboração: Fernando Fisbein

Paisagismo: Chácara Flor da Suíssa

Projeto: 2002

Conclusão: 2005

Construtora: ASW

Área: $622 \mathrm{~m} 2$

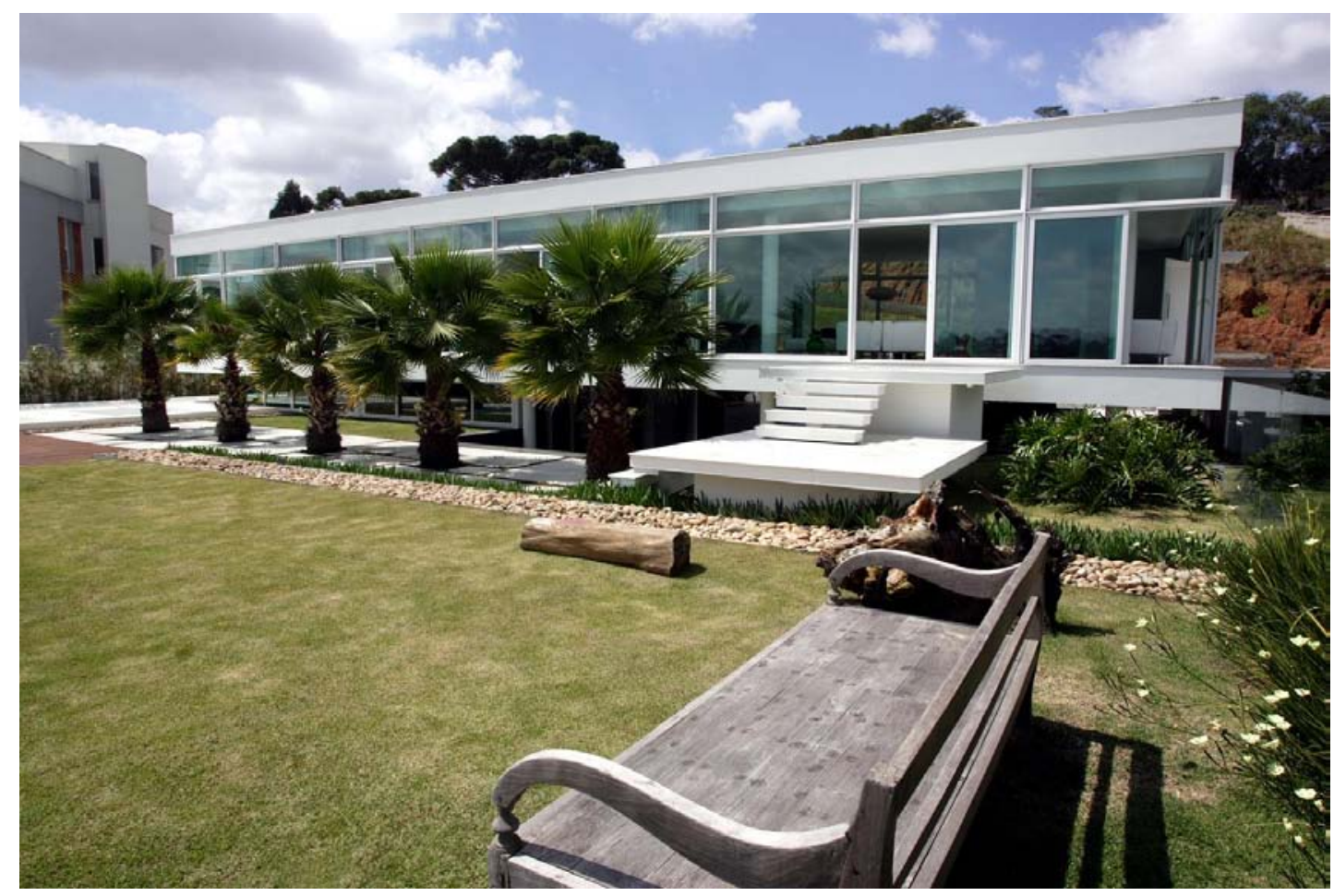

Figura 40 - Residência Casagrande Bertoldi: acesso principal 


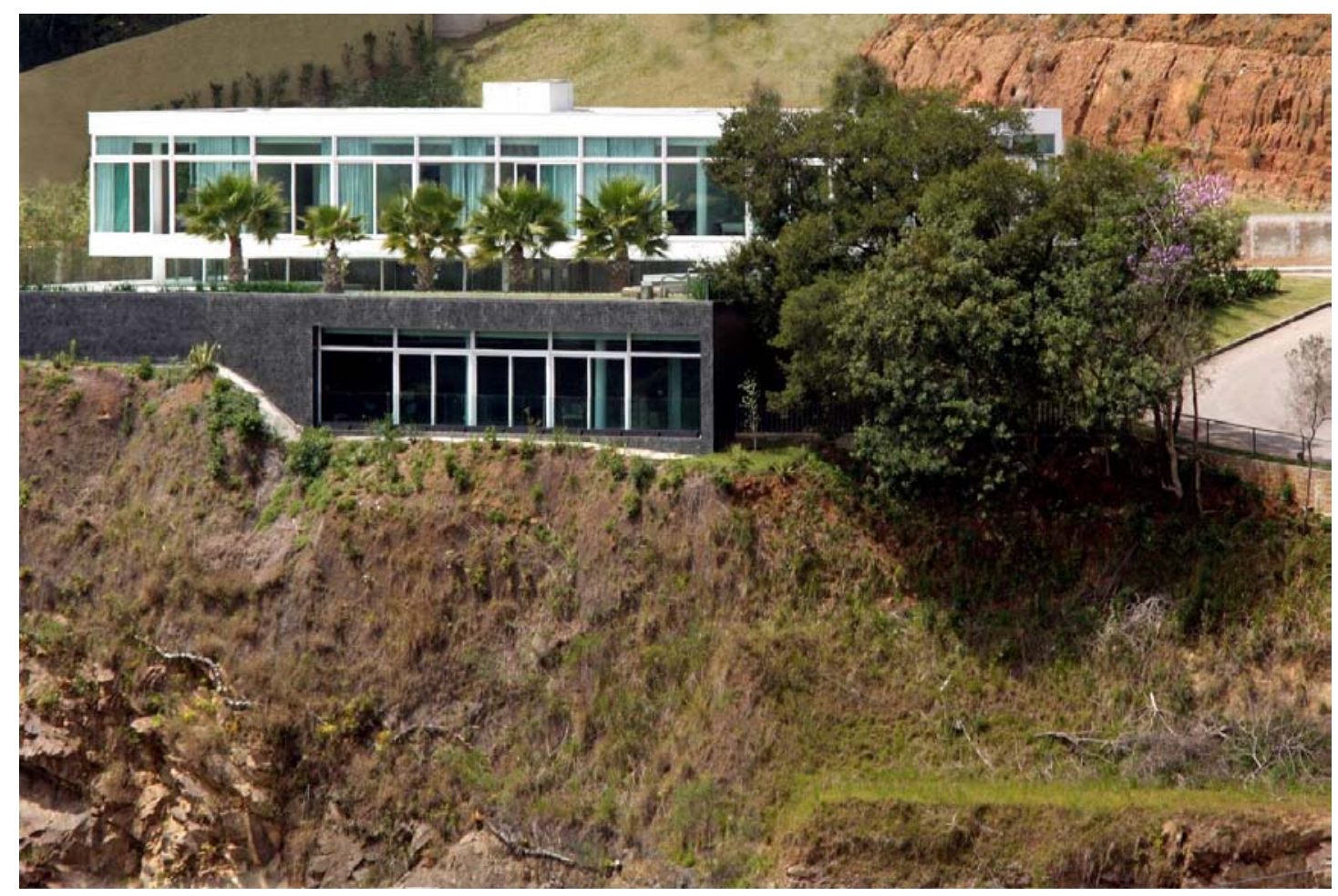

Figura 41 - Residência Casagrande Bertoldi: interior

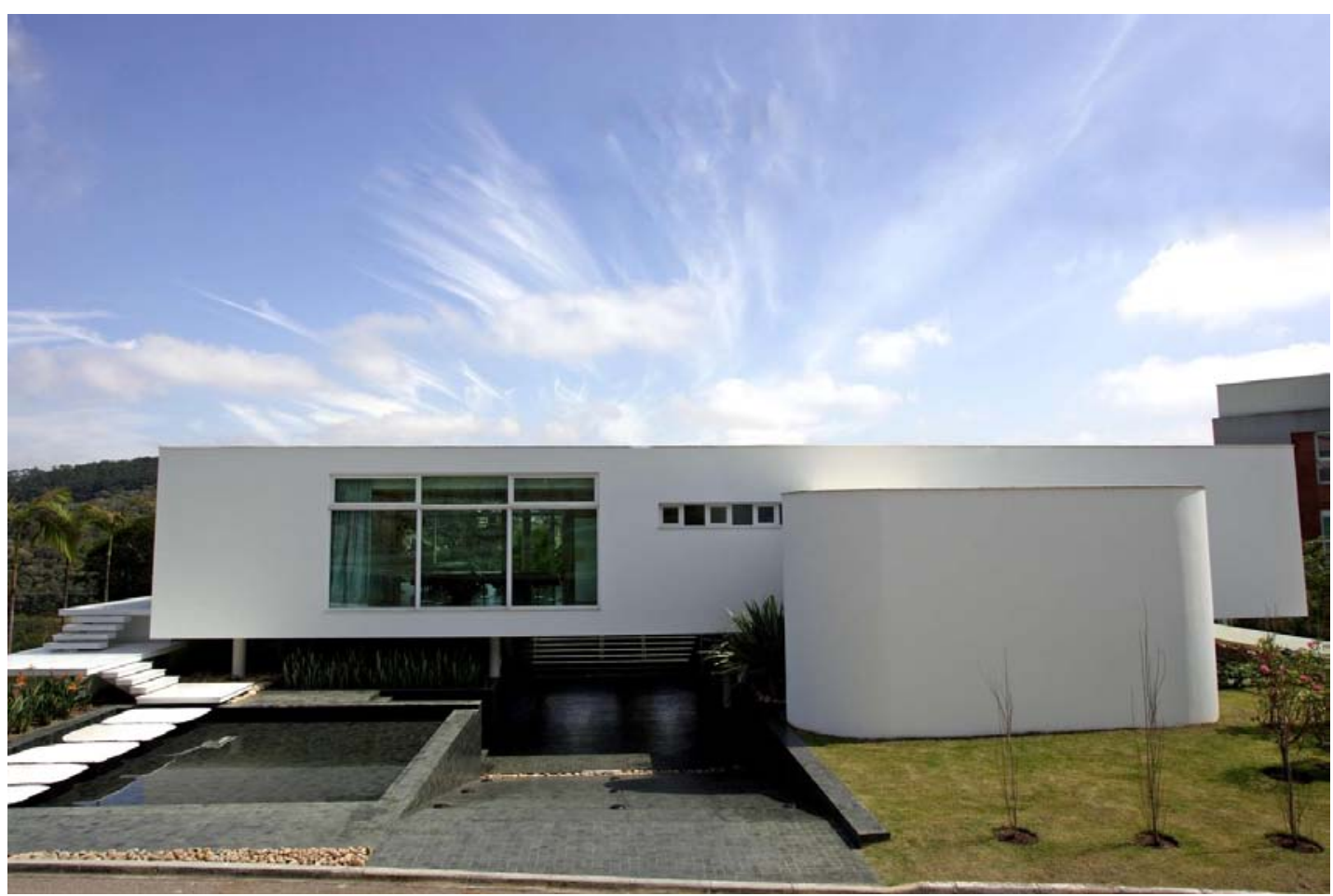

Figura 42 - Residência Casagrande Bertoldi: acesso veículos 


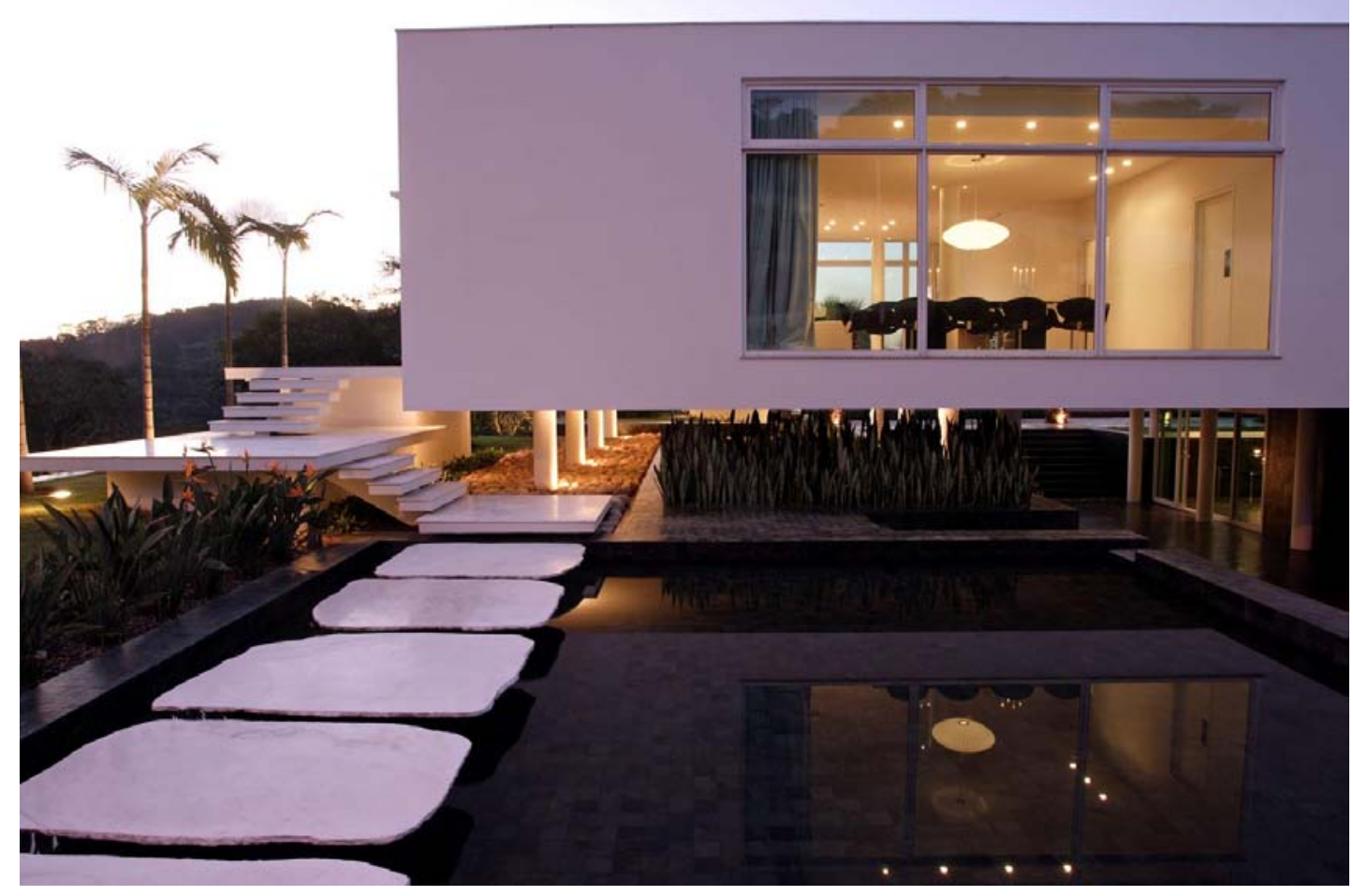

Figura 43 - Residência Casagrande Bertoldi: elevação lateral

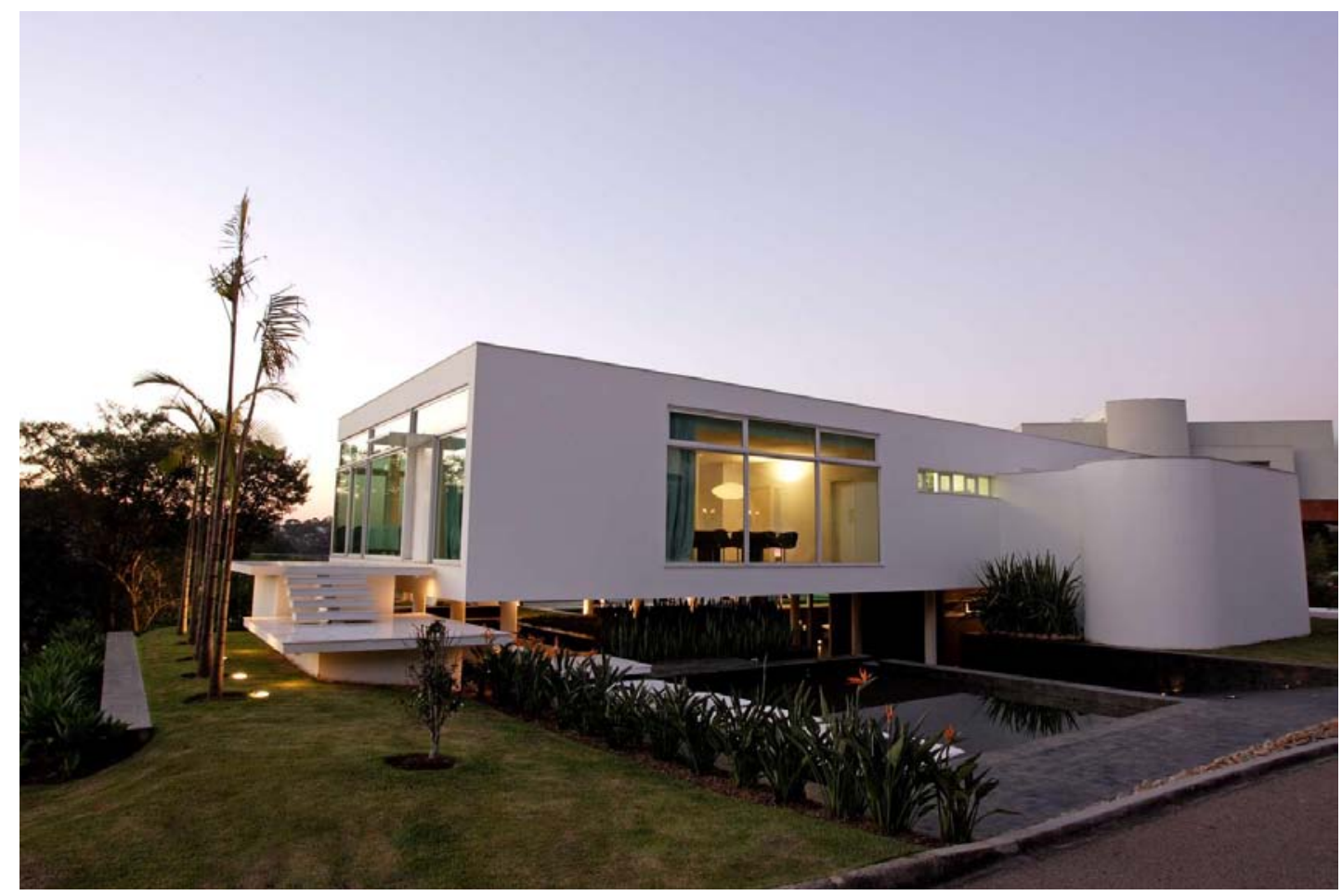

Figura 44 - Residência Casagrande Bertoldi: perspectiva 


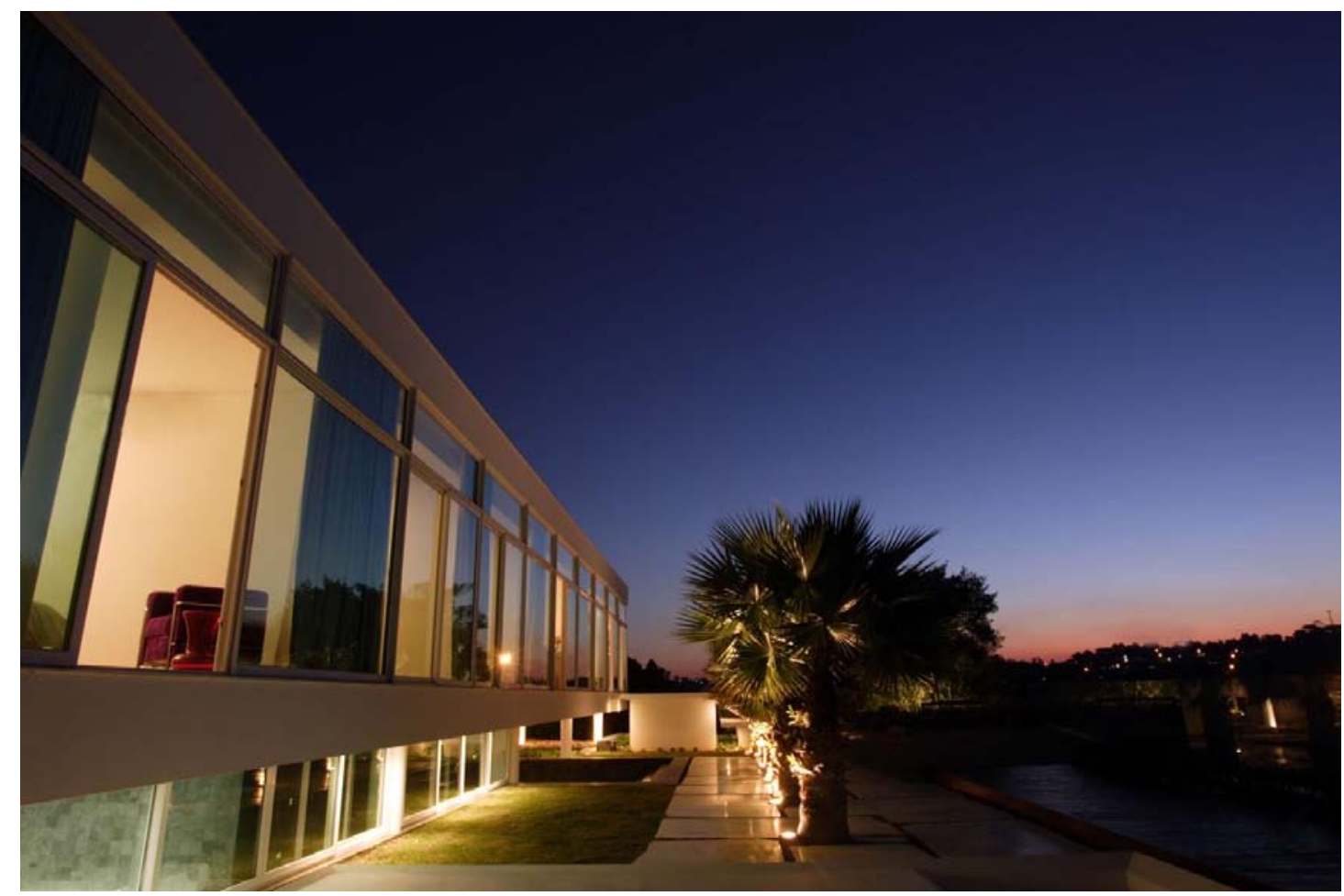

Figura 45 - Residência Casagrande Bertoldi: interior

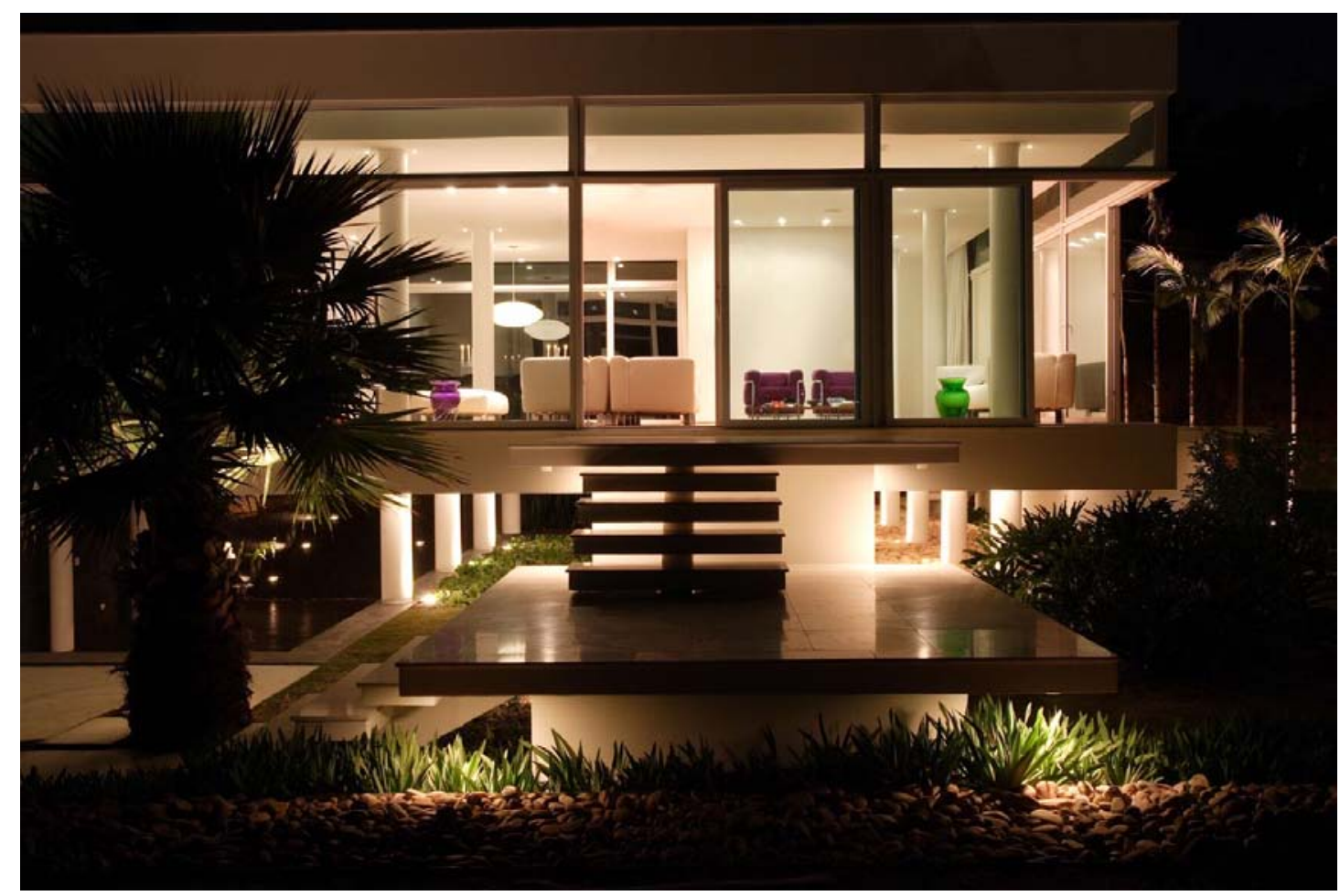

Figura 46 - Residência Casagrande Bertoldi: interior 


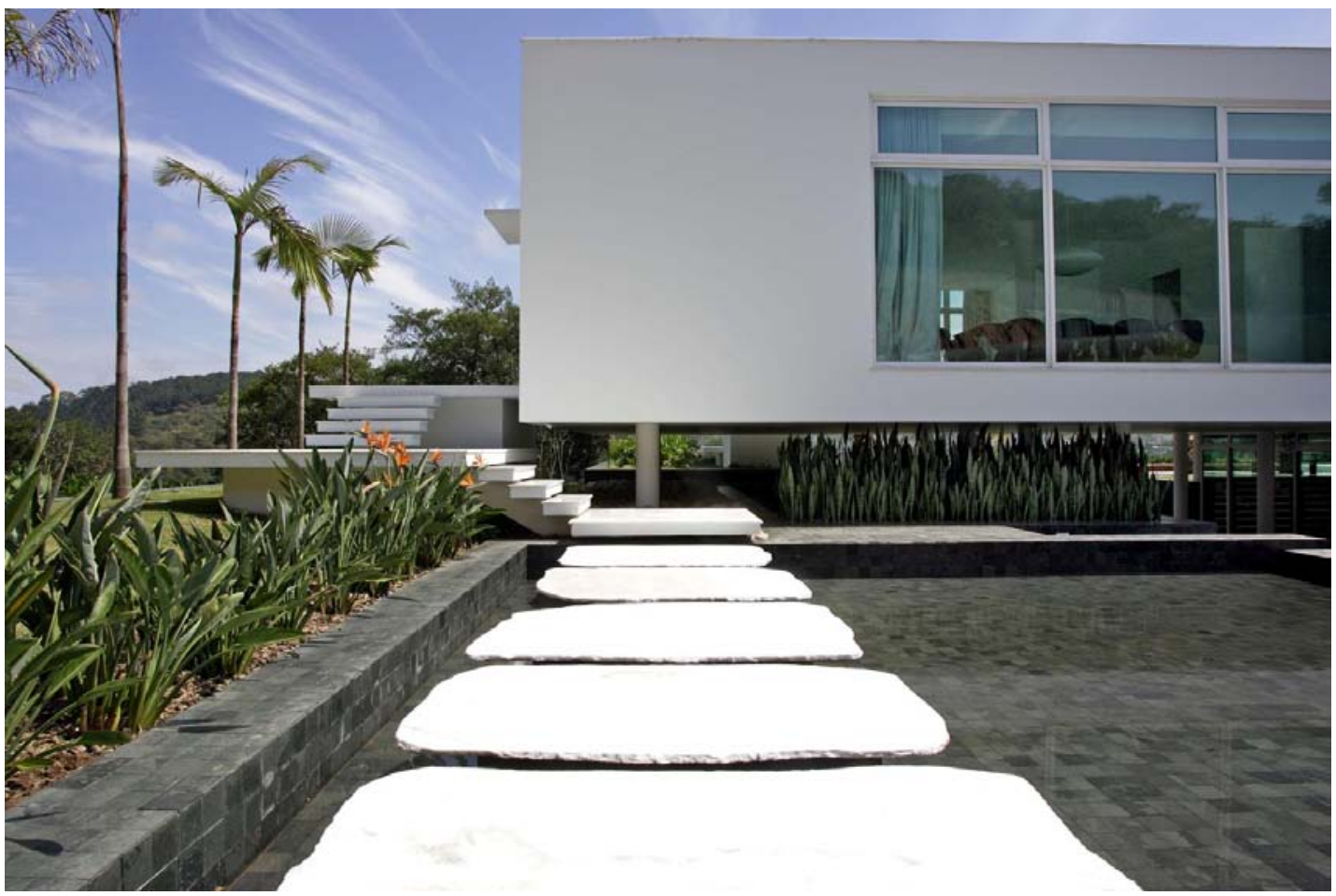

Figura 47 - Residência Casagrande Bertoldi: vista lateral

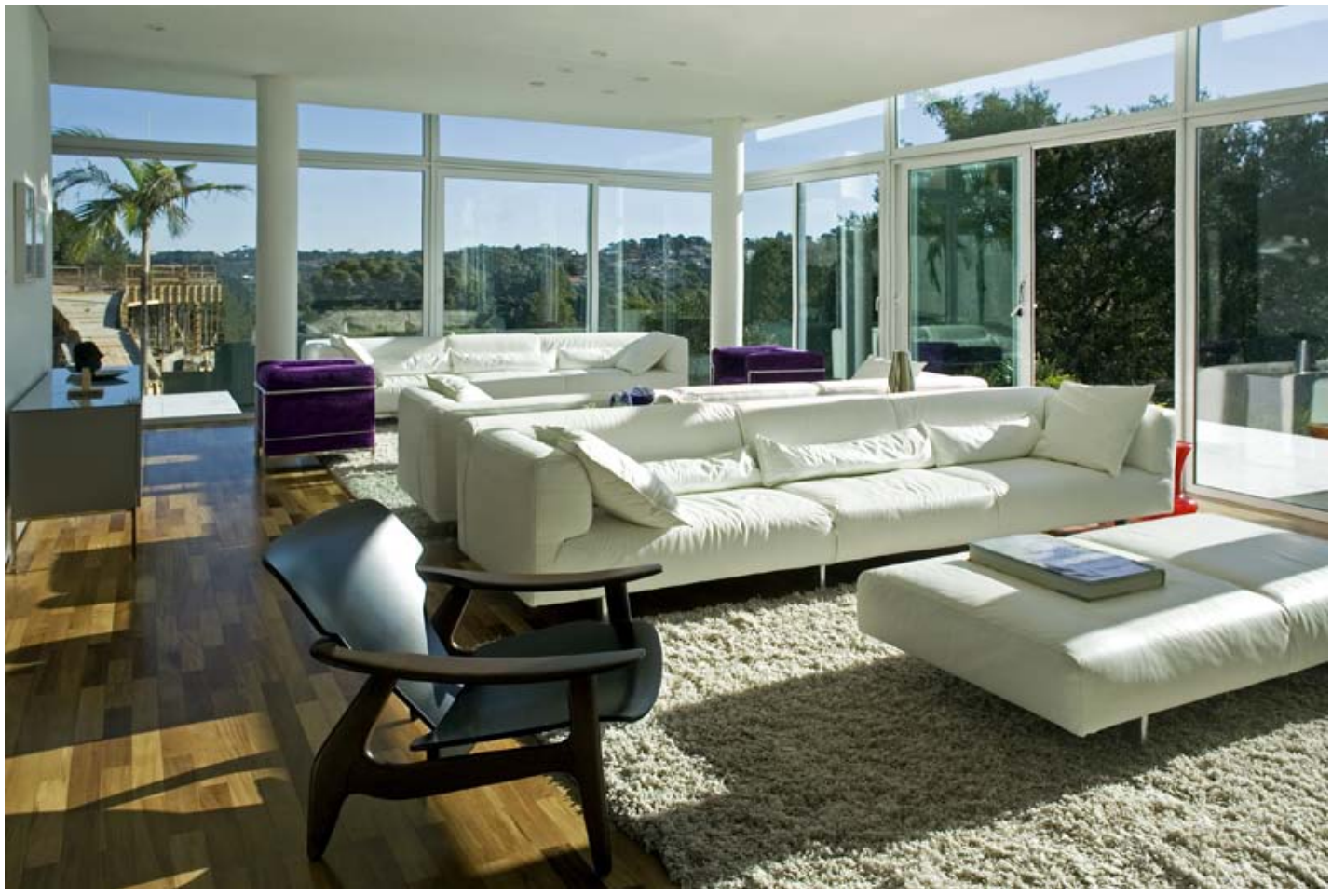

Figura 48 - Residência Casagrande Bertoldi: interior 


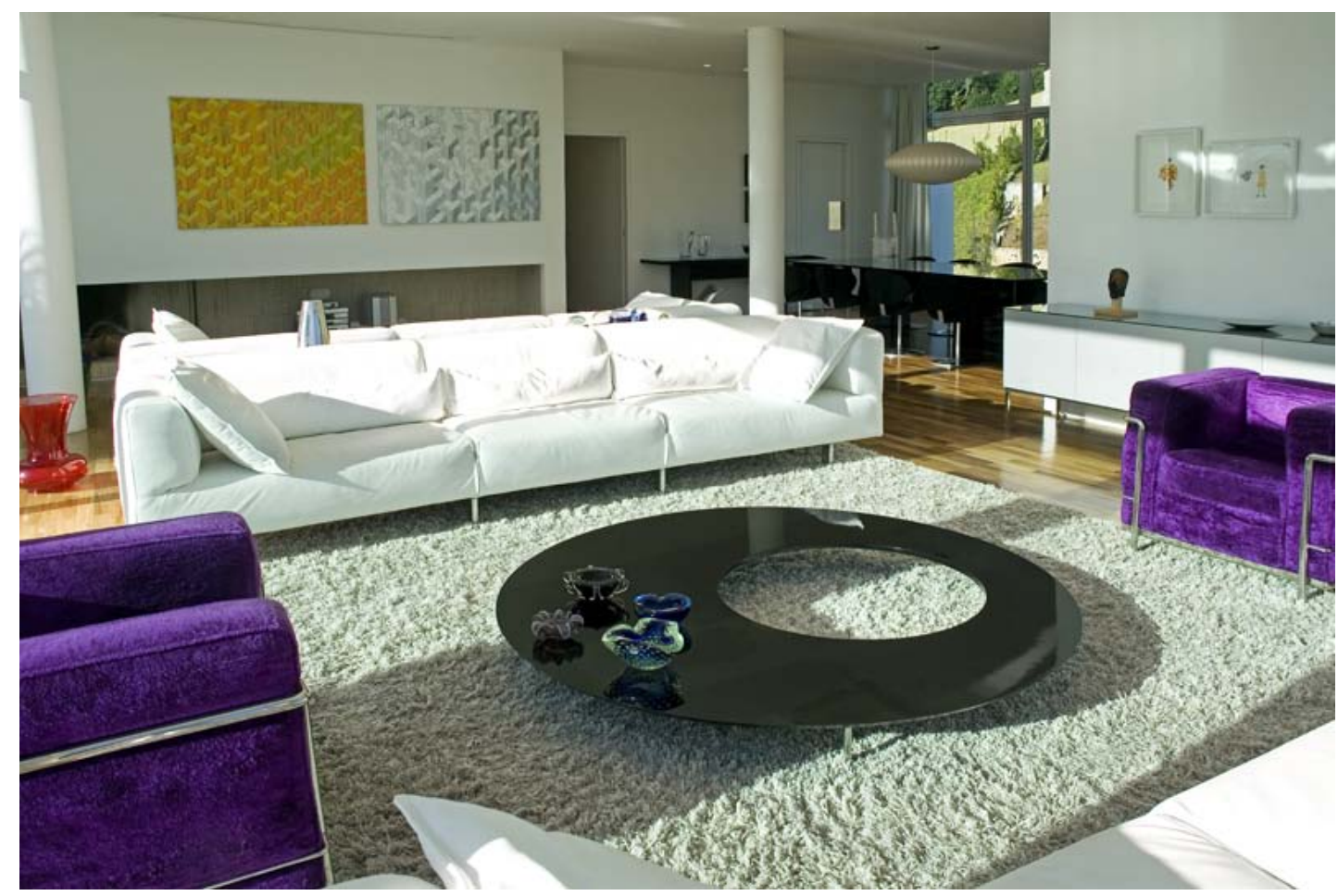

Figura 49 - Residência Casagrande Bertoldi: interior

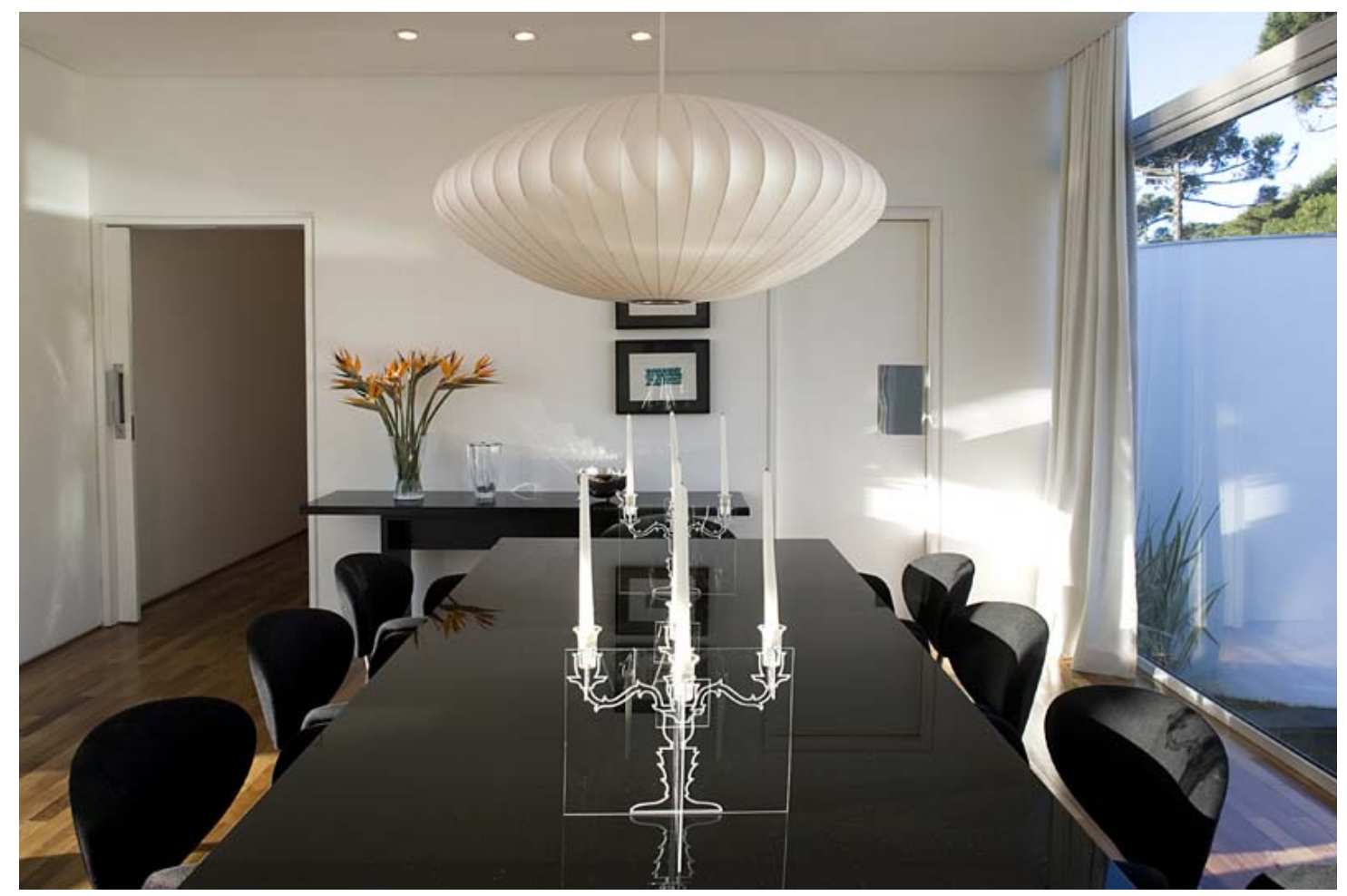

Figura 50 - Residência Casagrande Bertoldi: sala de jantar 

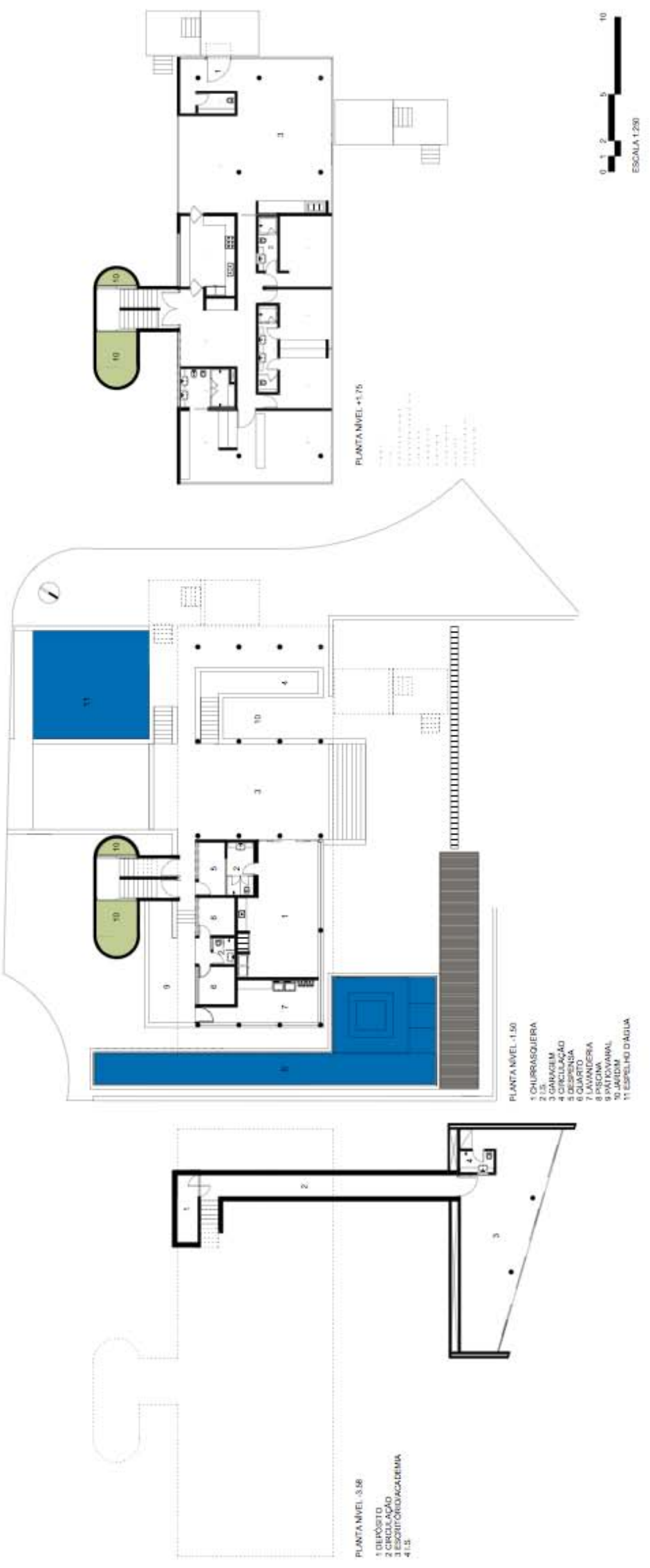

Figura 51 - Residência Casagrande Bertoldi: plantas 

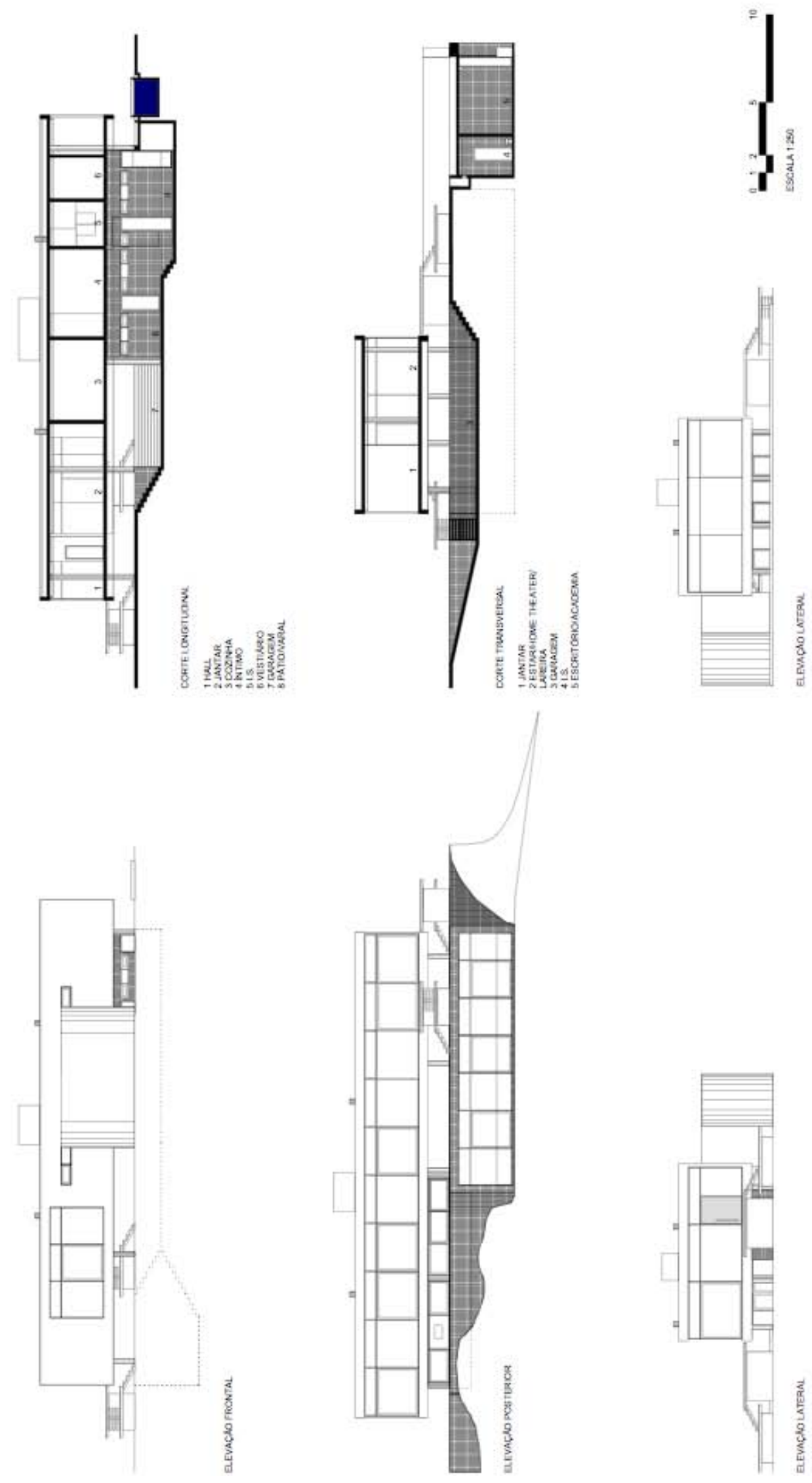

Figura 52 - Residência Casagrande Bertoldi: cortes e elevações 


\subsection{Visão geral}

Atuando há mais de duas décadas na área de arquitetura e paisagismo, o Studio Bertoldi é o escritório de arquitetura de Curitiba com maior repercussão internacional. Em menos de um ano, a revista americana Architectural Digest publicou duas obras do grupo de arquitetos liderados por Marcos Bertoldi - duas residências construídas em Curitiba. A revista alemã MD Moebel Interior Design publicou outra residência do arquiteto em sua edição de abril de 2008. O reconhecimento não acontece somente no exterior: em entrevista realizada com arquitetos de Curitiba, o Studio Bertoldi foi o escritório mais citado como referência de arquitetura contemporânea na cidade, em particular na tipologia residencial.

Construída sobre uma antiga pedreira, a residência projetada pelo arquiteto Marcos Bertoldi promove o encontro da linguagem racional com a implantação orgânica. Com clara influência da arquitetura de Mies Van der Rohe, a residência se desenvolve em volumes retilíneos: o primeiro, um volume semienterrado revestido de ardósia preta, posicionado organicamente no terreno e perfeitamente integrado com o entorno; e o segundo, o volume principal que abriga as áreas de estar, cozinha e dormitórios, apoiado sobre pilotis e com a face norte envidraçada, valorizando a visual do Parque Tingui.

Sob alguns aspectos - fachada cortina em vidro, volume semienterrado, uso de pilotis, detalhe e escolha criteriosa dos revestimentos da volumetria - a obra também remete a residência projetada em Bordeaux por Rem Koolhaas, em 1998.

\subsection{Implantação e relação com o entorno}

O projeto busca a preservação da planície formada sobre uma antiga pedreira e a requalificação paisagística do entorno imediato da obra. Também se pode observar a preocupação em manter o belvedere a partir do acesso principal de veículos e pedestres. 
A casa se divide em dois volumes distintos. O principal, apoiado sobre pilotis de $1,75 \mathrm{~m}$, caracteriza-se como um volume ortogonal com grandes planos de vidro, voltados para o norte, valorizando as visuais do sítio.

O volume semienterrado, inteiramente revestido em ardósia, acomodase a topografia original através da distribuição dos ambientes em meios-níveis.

Essa estratégia de divisão em volumes conferiu uma característica singular ao edifício em relação ao entorno. Enquanto o pavimento inferior se relaciona de forma mimética e perfeitamente integrada ao terreno, o volume principal ganha destaque visual em relação ao "pano de fundo". A integração do bloco em ardósia semienterrado no terreno em contraste com a linguagem racional do volume ortogonal remete a impressão de que este está "flutuando" livre de apoio, reforçando a singularidade da obra e marcando afirmativamente a presença do edifício na paisagem.

\subsection{Programa de atividades}

A distribuição dos espaços internos segue o conceito da divisão em da residência em patamares distintos, reconhecíveis a partir da volumetria da casa. No patamar inferior, assentado abaixo do nível da rua, estão distribuídas as áreas de serviço. No outro, suspenso sobre pilotis, as áreas de convivência e lazer da família.

Esta divisão em blocos de acordo com a topografia favoreceu a distribuição do programa de modo a garantir a separação entre a área íntima e a área social da casa. Os ambientes do volume principal - áreas de estar, dormitórios - estão orientados para o norte e se abrem para o interior do lote, através de uma fachada de vidros verdes do piso ao teto, com vista para o parque Tingui.

Os pisos inferiores, incrustados no terreno, incluem, além das áreas de serviço, uma ampla e bem iluminada academia de ginástica, que também desfruta a vista do parque. As áreas fechadas - como dormitórios de serviço, lavanderia, despensa - gradativamente se diluem em espaços contínuos com vista para o parque, como o terraço da churrasqueira e a garagem. 
$\mathrm{Na}$ área externa, uma piscina de raia única com vinte metros de comprimento reflete a volumetria do edifício e dialoga com o projeto de paisagismo.

\subsection{Partido arquitetônico}

O partido da casa tem sua origem em uma construção contemporânea em busca da integração entre natureza e arquitetura, com influências do período áureo do movimento moderno no Brasileiro e resgate de elementos desta arquitetura.

Elevado por pilotis em relação ao nível do terreno, o bloco ortogonal valoriza a paisagem do entorno e emoldura as visuais da natureza que circunda a obra. A fluidez dos espaços internos e os grandes planos de vidro integram o exterior e interior, fazendo dos jardins uma continuação do espaço interno da casa.

O contraste entre os projetos de arquitetura e paisagismo resultam numa dualidade singular nesta obra: a simplicidade do volume branco dá destaque ao colorido das plantas tropicais utilizadas no paisagismo. A imponência das palmeiras, que demarcam a entrada da residência, valoriza a promenade arquitetural.

\subsection{Sistema construtivo}

A construção em concreto armado - material amplamente utilizado nas residências de Curitiba da década de 60 e 70 - resgata a tradição desta técnica construtiva, característica da arquitetura moderna brasileira, mas também procura fazer uso desta tecnologia de forma mais avançada, associada a novas tecnologias e possibilidades plásticas.

As lajes de concreto do bloco suspenso se apoiam em pilares circulares externos aos planos de vedação, configurando uma estrutura que se organiza sob a forma de uma fachada cortina e apoios independentes. Estes pilares se prolongam até o bloco de ardósia preta, conferindo ao edifício uma estrutura modular comum aos dois blocos. 
O sistema construtivo utilizado na cobertura é laje impermeabilizada. $\mathrm{O}$ patamar da escada do acesso principal, em concreto armado, remete a residência Farnsworth, obra prima de Mies van der Rohe.

\subsection{Intenção Plástica}

Embora tenha semelhanças estéticas e nítida influência de alguns aspectos da doutrina modernista, a casa nitidamente pertence e dialoga com a contemporaneidade. $\mathrm{O}$ que é análogo nesta residência e algumas residências do período mais influente da arquitetura de Curitiba - em particular, a arquitetura das décadas de 60 e 70 - são as inspirações e alguns detalhes figurativos (os pilotis, os planos de vidro, a forma ortogonal).

Apesar das semelhanças, este projeto não se caracteriza como um revival da modernidade, e sim como uma continuidade de uma atitude projetual que, embora questionada e readequada ao longo de anos de desenvolvimento da arquitetura e da sociedade, mostrou-se qualificada, interessante, e com embasamento teórico suficiente para manter relevante durante décadas. 


\section{ATRIO ARQUITETURA: CASA NVL}

Residência em Condomínio Fechado

Curitiba, Paraná

Arquitetos: Maurício Melara, Gustavo Pinto

Projeto: 2004

Construção: 2006

Área: 443,87

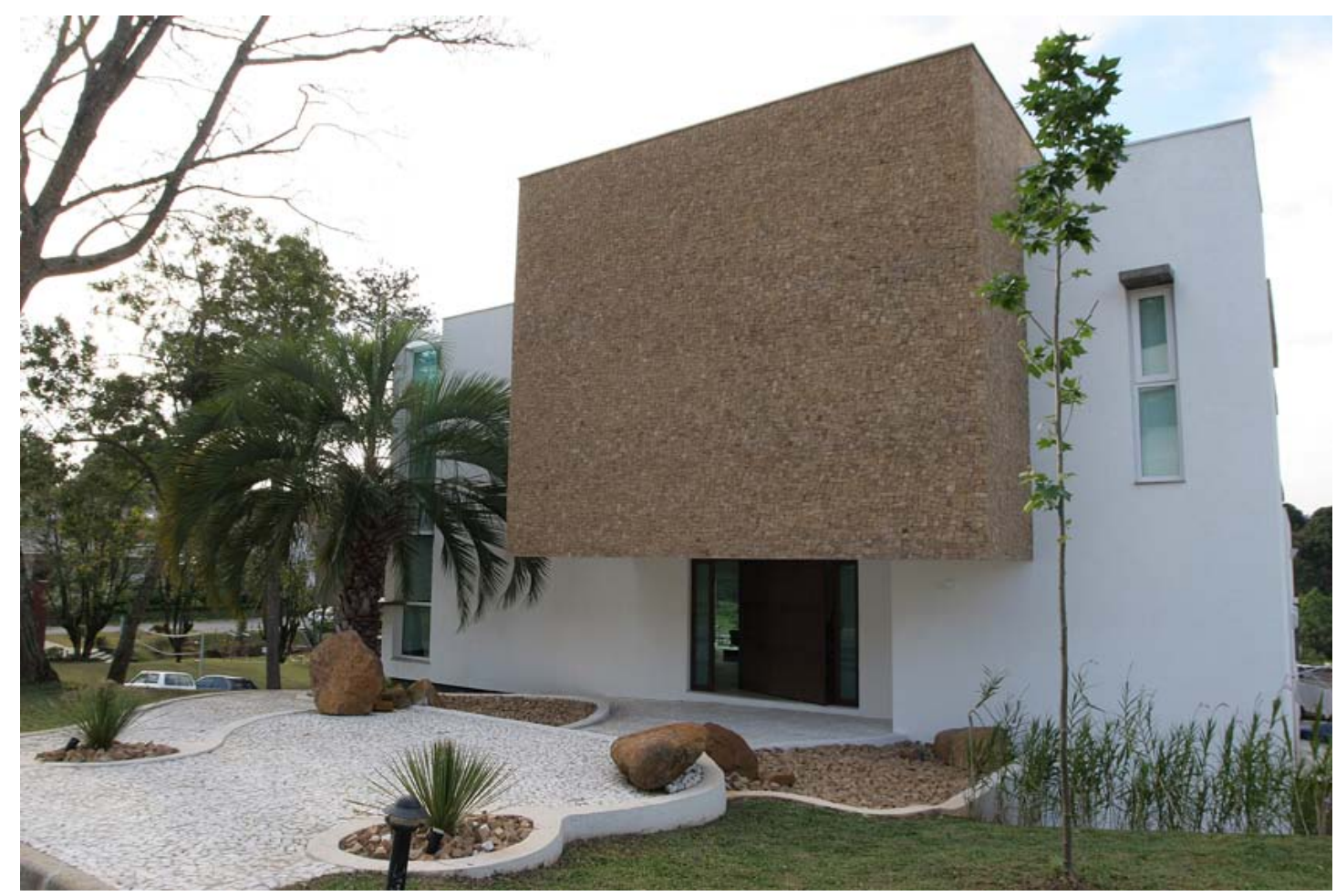

Figura 53 - Residência Átrio Arquitetura: geral 


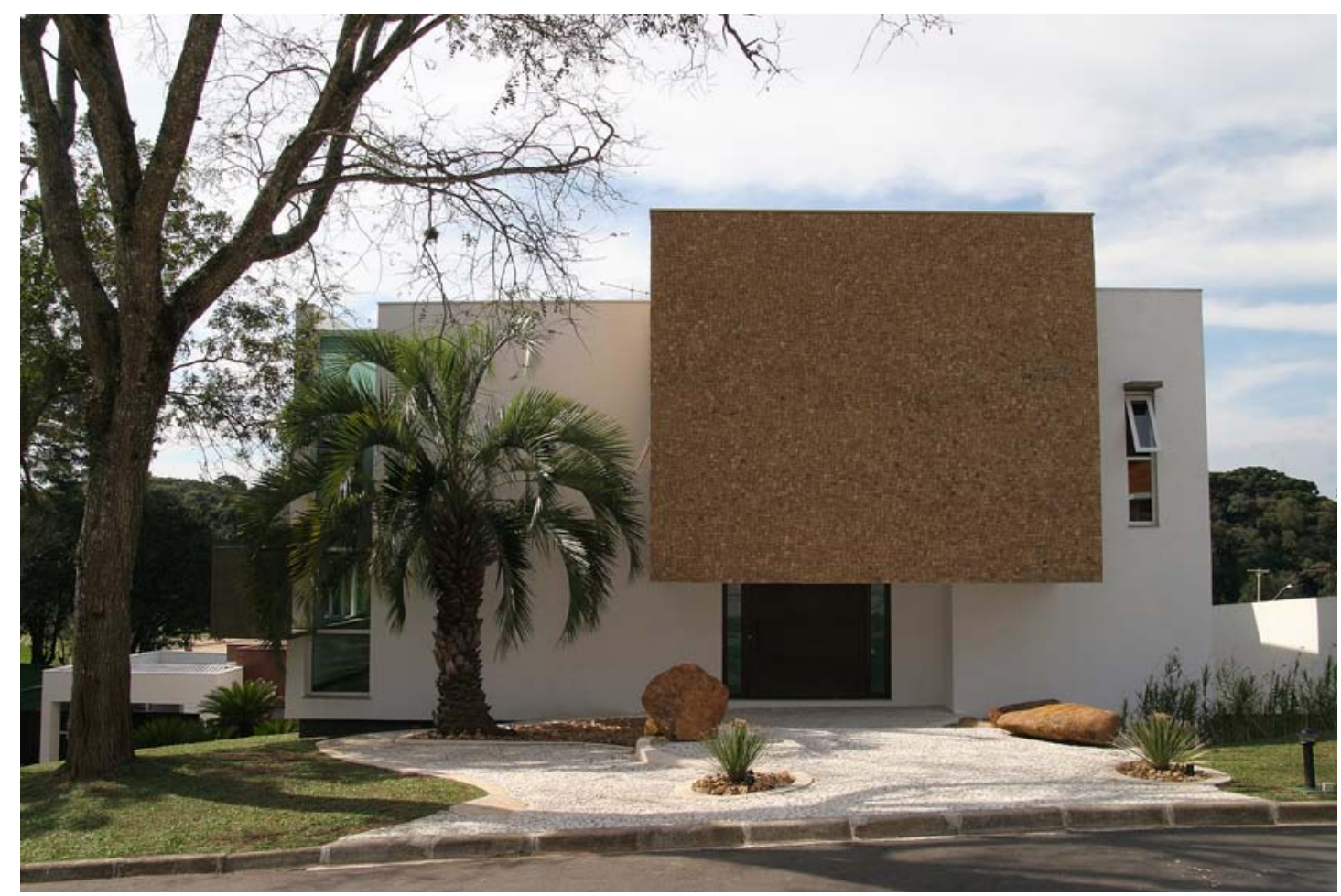

Figura 54 - Residência Átrio Arquitetura: acesso principal

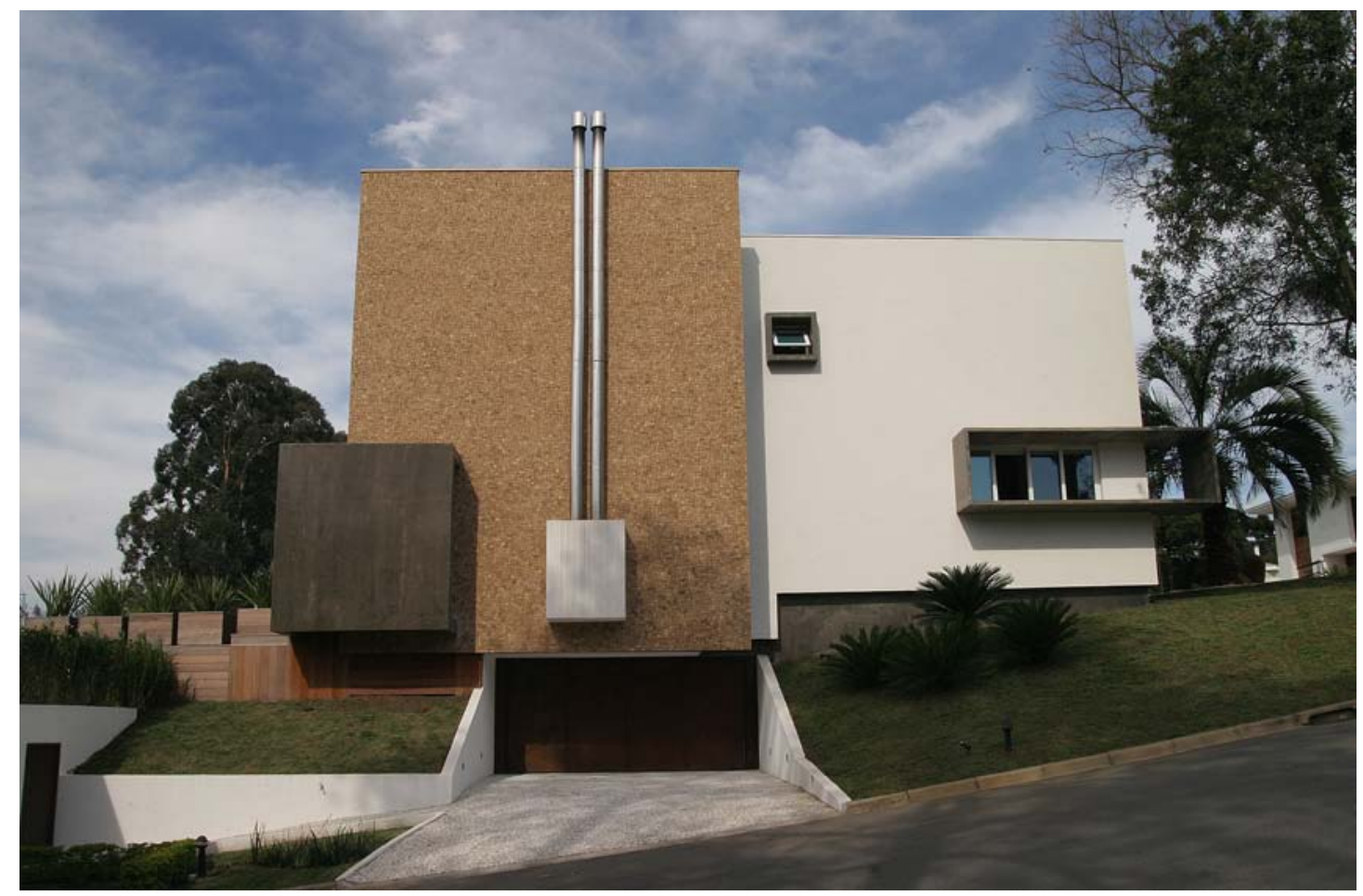

Figura 55 - Residência Átrio Arquitetura: acesso garagem 


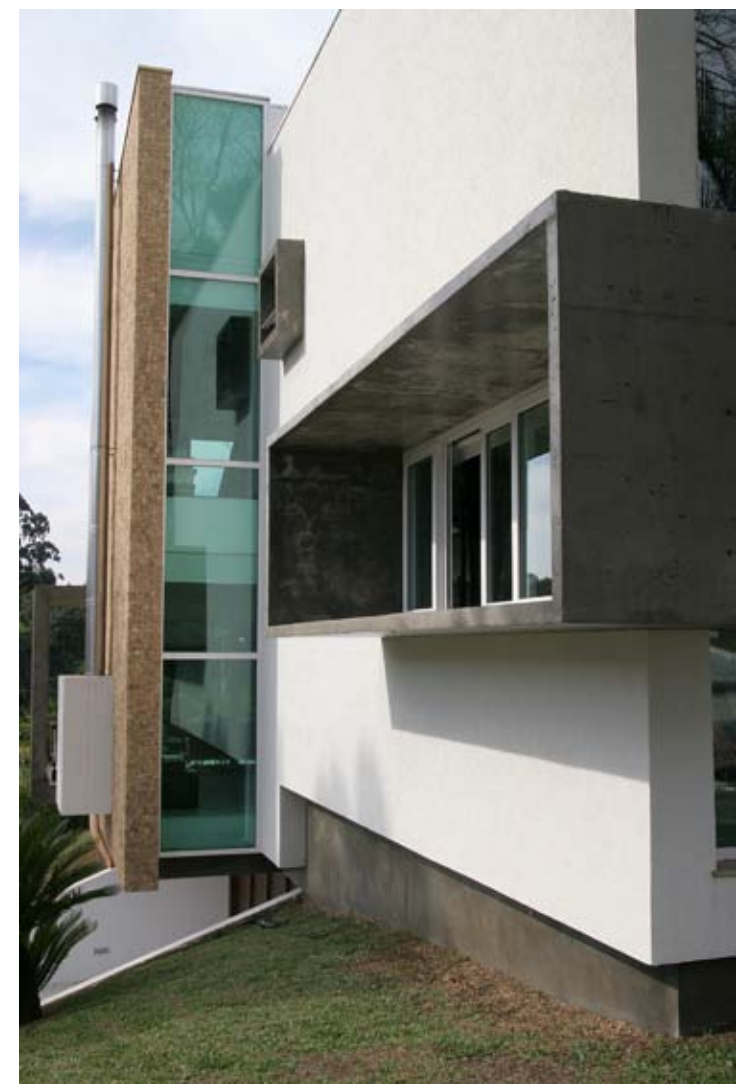

Figura 56 - Residência Átrio Arquitetura: detalhe aberturas

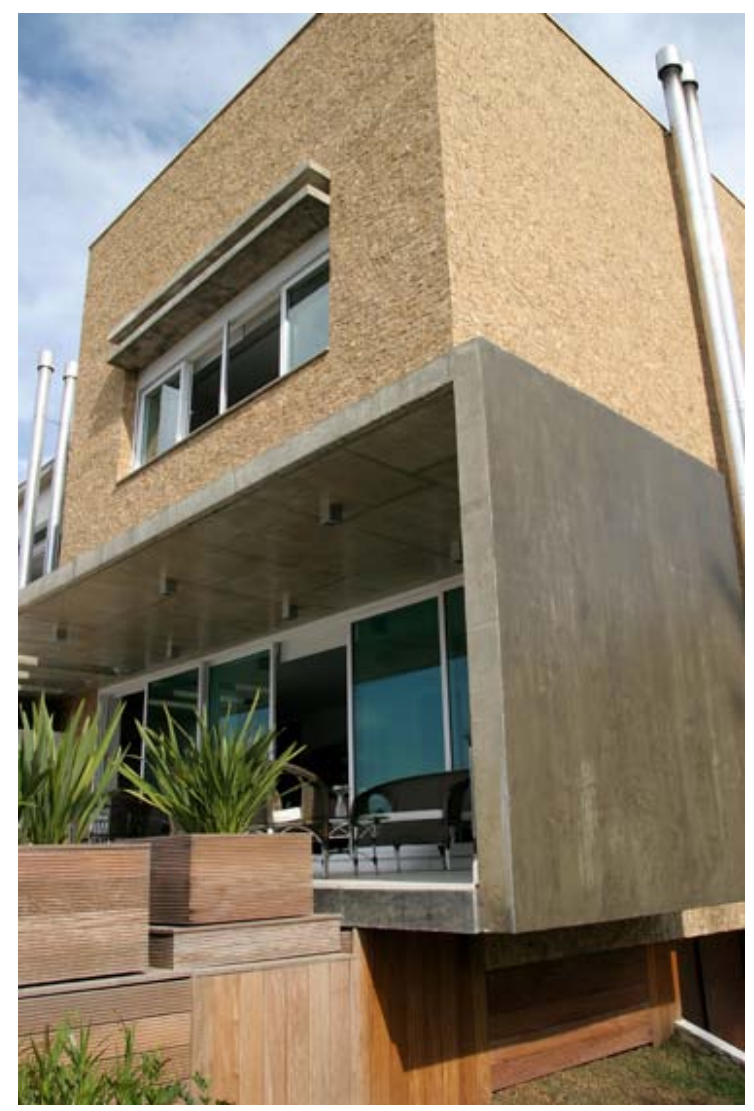

Figura 57 - Residência Átrio Arquitetura: fundos 


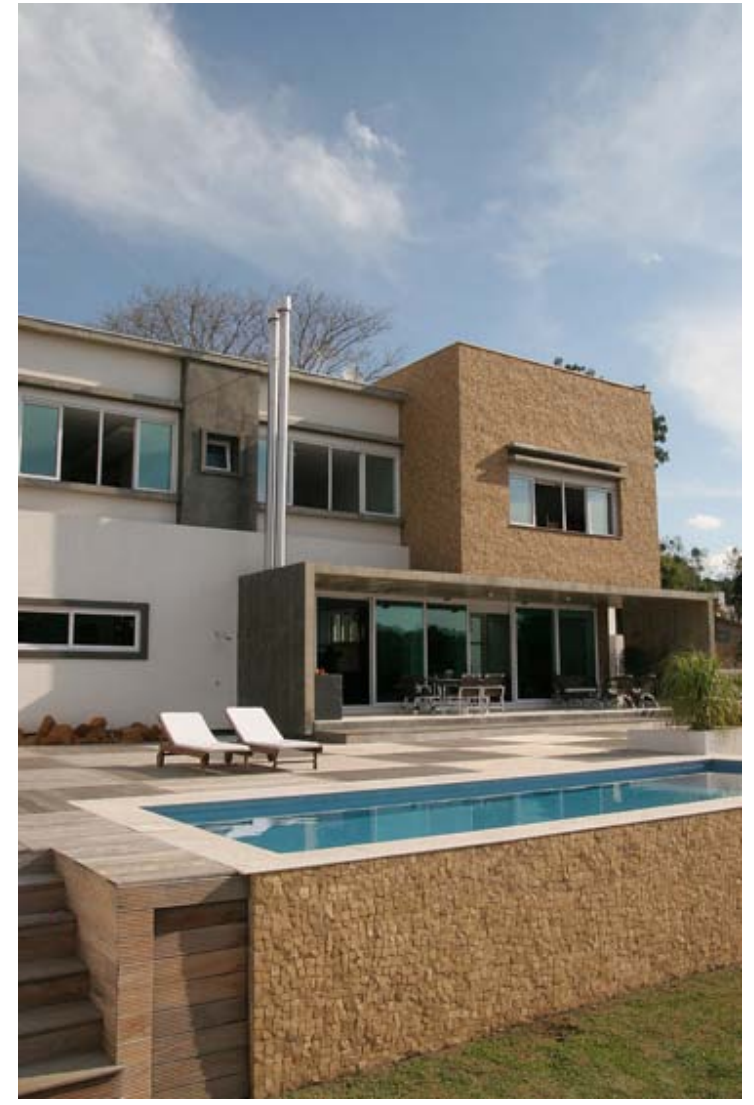

Figura 58 - Residência Átrio Arquitetura: piscina

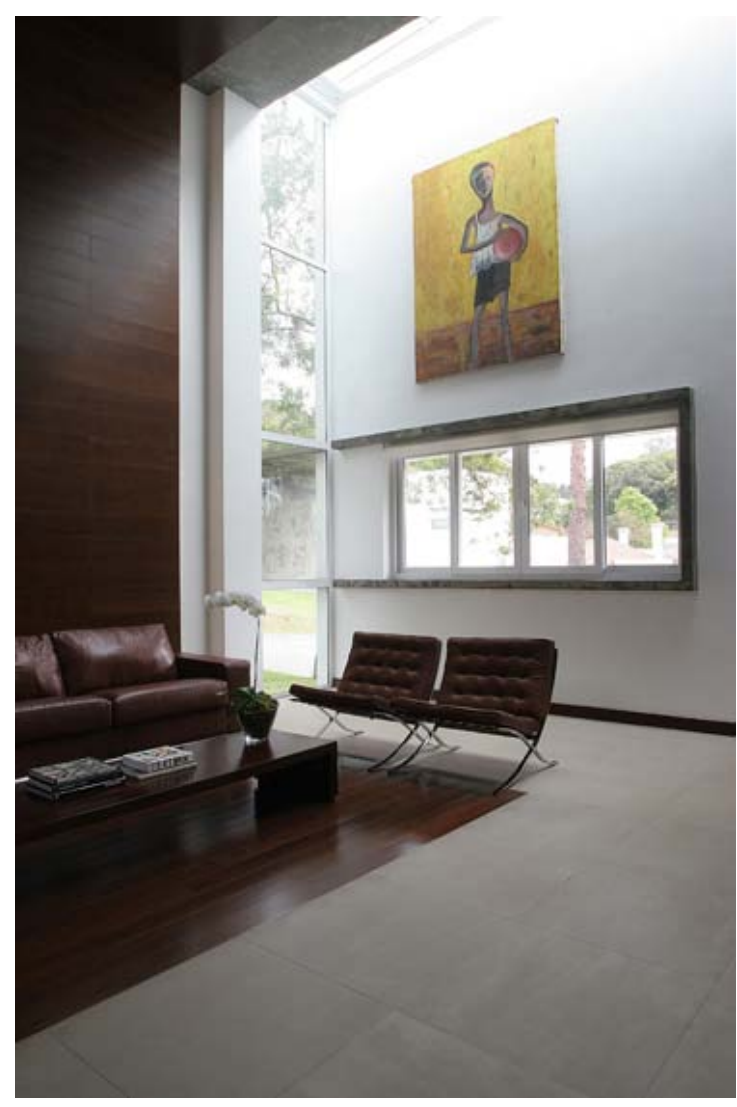

Figura 59 - Residência Átrio Arquitetura: interior 


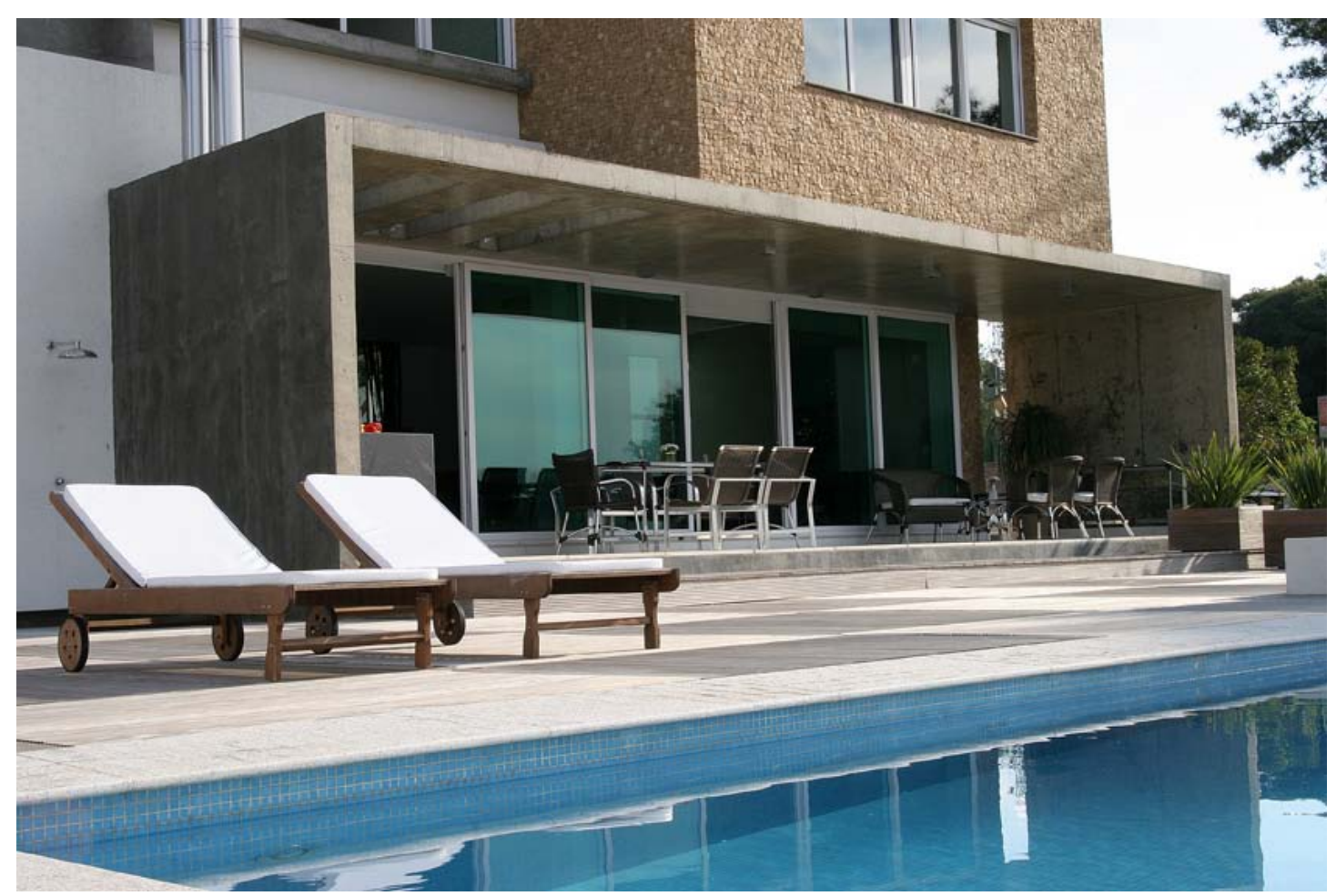

Figura 60 - Residência Átrio Arquitetura: fundos

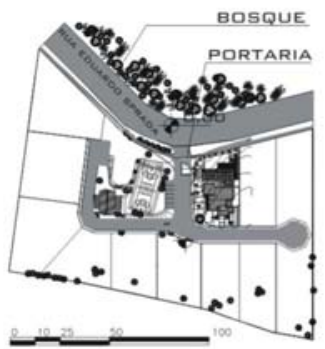

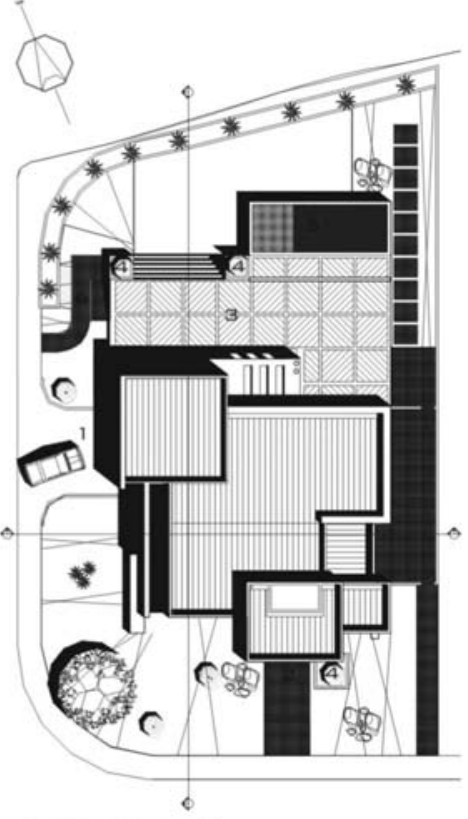

IMPLANTAÇÃO
1. Acesso veiculos
2. ACKsso prokgtars

3. Decek
4. Foreira

2. miscina

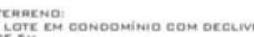

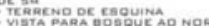

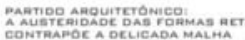

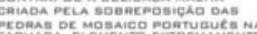
(4)

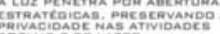

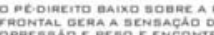

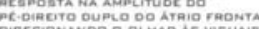
Dagecligk

Figura 61 - Residência Átrio Arquitetura: implantação 

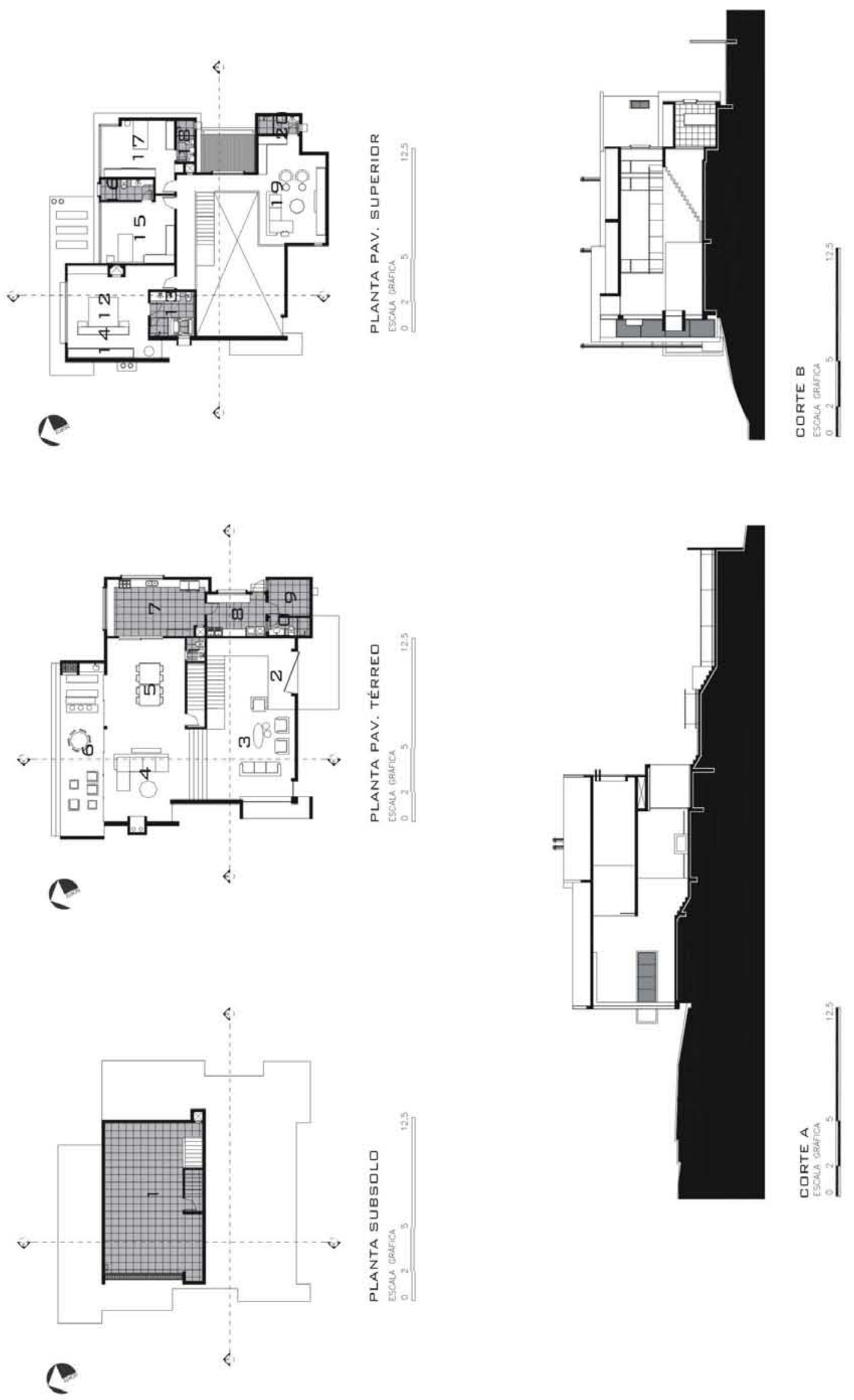

w

Figura 62 - Residência Átrio Arquitetura: plantas e cortes 

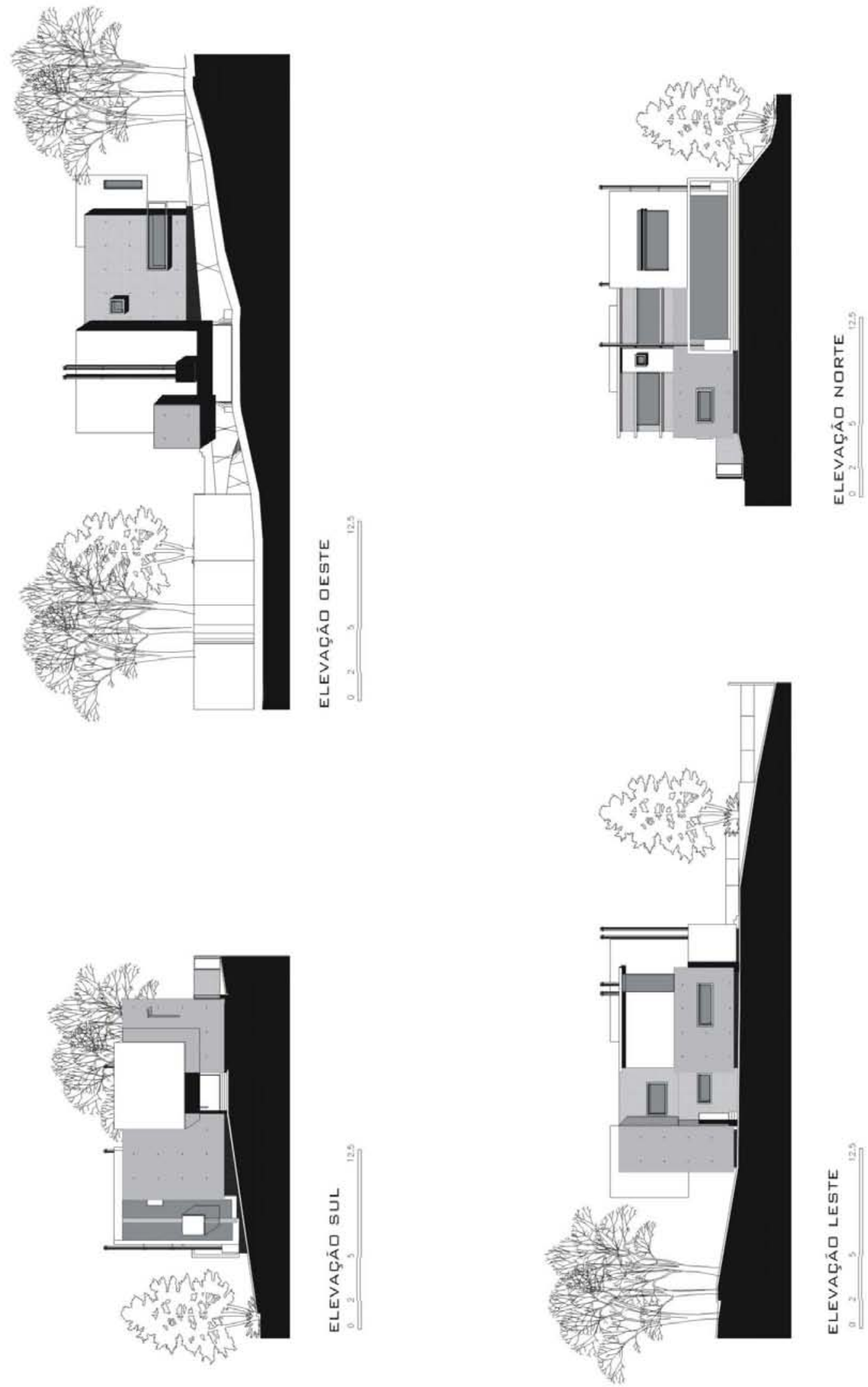

Figura 63 - Residência Átrio Arquitetura: elevações 


\subsection{Visão geral}

Trata-se de uma residência de 456,00m2 localizada num condomínio fechado em Curitiba. O projeto desenvolve-se em três pavimentos e um subsolo, em conformidade com as características topográficas do terreno.

O pavimento térreo constitui o acesso principal e concentra as áreas sociais e de serviço da residência - hall, estar, lareira, jantar, churrasqueira, cozinha, lavanderia e quarto de serviço. No segundo pavimento estão os quartos e o home theater.

O partido formal foi consolidando-se a partir de constantes visitas com o cliente no local da obra. As solicitações direcionavam os estudos para um projeto com personalidade formal própria, ecologicamente correto e uma obra rápida.

O volume do edifício caracteriza-se pela contraposição da austeridade das formas retas e a delicada malha de revestimento, criada pela sobreposição das pedras de mosaico português na fachada. A luz penetra por aberturas estratégicas, preservando a privacidade nas atividades sociais e de lazer. A sensação de opressão e peso causada pelo pé-direito baixo sobre a porta frontal encontra seu equilíbrio na amplitude do pé-direito duplo do átrio, favorecendo as visuais do bosque.

\subsection{Implantação e relação com o entorno}

A residência está implantada em um terreno de esquina, que apresenta um declive de $5 \mathrm{~m}$ no sentido de seu maior comprimento. O projeto considera o entorno como parte da composição, tirando partido da topografia para gerar desníveis entre ambientes e assentar melhor o volume. Desta forma, garante a continuidade visual e sensação de amplitude entre a sala de estar - com pé-direito duplo - e a sala de jantar / lareira, voltadas para os fundos do terreno e meio nível abaixo da entrada principal.

O acesso principal é feito a partir de um pátio de contornos sinuosos, revestido de petit pavé. A entrada principal é marcada por uma abertura discreta sob um volume quadrangular revestido por pedras de mosaico português. As aberturas 
da fachada principal - assim como de boa parte do projeto - configuram-se como rasgos nas extremidades do volume, garantindo luz natural nos ambientes, sem comprometer a privacidade.

O partido decorre esquematicamente da articulação de volumes retos de texturas variadas e contrastantes. $\mathrm{O}$ arquiteto optou por trabalhar alternando o uso de alvenaria branca, concreto aparente e superfícies rústicas, revestidas em pedra. As duas fachadas, voltadas para a esquina, possuem aberturas discretas, enquanto os fundos da residência - voltado para a piscina - caracteriza-se por grandes planos envidraçados.

O acesso aos pavimentos superiores é feito pela escada localizada na área de estar - ambiente de pé-direito duplo, iluminado pela abertura vertical da fachada principal.

\subsection{Programa de atividades}

O arquiteto trabalha o terreno em desníveis sucessivos, a fim de caracterizar melhor as distintas áreas da residência, e para melhor assentamento do projeto no terreno. A opção por implantar a sala de jantar, em cota altimétrica inferior ao nível de acesso, favoreceu o melhor assentamento do volume no terreno. Ainda, com objetivo de adaptar a obra ao terreno, optou-se por posicionar a garagem sob a sala de jantar, com acesso pela via lateral.

A entrada principal do edifício corresponde a uma discreta abertura sob um imponente volume, revestido de material rústico, que, destaca-se do restante da composição, demarcando o acesso principal. O volume configura-se como um marco de entrada, garantindo a proteção do acesso principal.

O acesso acontece por um hall de pé-direito baixo, seguido da amplitude do estar, com pé-direito duplo e favorecendo as visuais para o bosque. A cozinha aparece anexa à sala de jantar, separada por uma porta de correr, dando a opção de explorar a continuidade entre os dois ambientes ou, então, de manter as áreas de serviço da residência resguardadas. Jantar e lareira estão voltados para a fachada norte/leste, protegidos da insolação excessiva característica do verão pela cobertura da varanda. 
No andar superior, priorizou-se a orientação norte dos quartos para garantir o conforto ambiental destas áreas. O acesso ao segundo pavimento acontece pela escada, que parte do estar principal, no térreo, e encontra a circulação que emoldura o átrio. Esta circulação leva até as três suítes da residência - uma para casal e duas de solteiro. O home theater foi posicionado em oposição à área dos quartos. Está localizado na face sul da construção e não possui aberturas nesta orientação. A única abertura do ambiente tem direção oeste e está posicionada de forma a não comprometer a adequação térmica do ambiente.

Buscando preservar a intimidade dos moradores, algumas aberturas foram posicionadas em forma de rasgos longilíneos, garantindo a adequação lumínica, sem comprometer a privacidade das áreas sociais e de lazer, localizadas no térreo.

\subsection{Partido Arquitetônico}

Duas atitudes de projeto nortearam o processo de concepção da residência e as escolhas do arquiteto: a adequação do projeto às características do lugar, tanto em relação a questões topográficas, quanto adequação do programa em relação à orientação do edifício; a volumetria rigorosa, valorizada pela alternância de materiais - concreto aparente, alvenaria branca, pedras de mosaico - e destacada, através de aberturas em forma de rasgos - verticais e horizontais - dando destaque a planos da fachada e diferenciação dos blocos.

A volumetria reflete a divisão do programa no interior da residência, facilitando a leitura do edifício. O posicionamento cuidadoso das aberturas procura manter a privacidade das áreas de lazer e social e valorizar as visuais do bosque.

O aproveitamento da luz natural, e o jogo de luz e sombra proporcionado pelos rasgos distribuídos em pontos estratégicos da construção trazem a sensação de conforto e acolhimento. $\mathrm{O}$ arquiteto traz a mesma diversidade de materiais da fachada para o interior da residência, alternando vidro, madeira, porcelanato e alvenaria em uma surpreendente composição de texturas. $O$ pé-direito de alguns ambientes é significativamente baixo - como acontece na entrada da residência mas geralmente esta característica ocorre em áreas de passagem ou transição (hall, circulações). Esta característica das áreas de passagem aumenta a sensação de 
amplitude na transição entre estas e os espaços com pé-direito amplo e bem iluminados, em particular o estar situado no pavimento de acesso.

\subsection{Sistema Construtivo}

Utilizou-se um sistema estrutural composto de vigas e pilares de concreto. Os planos dos pilares coincidem com os planos de fechamento, não é clara a distinção entre vedações e elementos portantes. A solução estrutural também não privilegia o estabelecimento de uma modulação básica a ordenar o espaço construído. No entanto, conforme pode ser apreendido dos projetos de execução, a solução estrutural do conjunto é relativamente simples.

$\mathrm{Na}$ cobertura, foi optado pelo uso de laje impermeabilizada. Para as vedações, o arquiteto alterna entre alvenarias de tijolos - pintadas na cor branca ou revestidas de petit pavé - e blocos de concreto aparente.

O pátio de entrada é revestido por petit pavé na cor branca e a área da piscina possui piso em deck de madeira. O arquiteto tira partido estético das chaminés da lareira e churrasqueira. A construção utiliza vidros verdes para melhor controle da insolação.

\subsection{Intenção Plástica}

O arquiteto buscou explorar as qualidades materiais e plásticas dos elementos de vedação. Para as vedações, escolheu alvenaria pintada de branco e blocos de concreto com acabamento envernizado. Em alguns volumes, optou por revestir as superfícies com petit pavé marrom. O posicionamento das aberturas favorece o destaque dos blocos do projeto, tornando a volumetria ainda mais forte e evidente.

O rigor formal, marcado por linhas retas e bem definidas encontra contraponto na leveza do petit pavé marrom, utilizado no revestimento de alguns volumes. As janelas - todas em vidro verde, buscando o conforto térmico da edificação - são demarcadas por molduras em concreto aparente. 
O jogo de volumes e a alternância de texturas proporcionada pelos diferentes materiais - petit pavé, alvenaria branca, concreto aparente - torna a residência esteticamente interessante. A articulação dos volumes, observada no exterior do edifício reflete a solução compositiva da planta.

O tratamento plástico dado a chaminés e outros elementos de instalação remete a arquitetura high tech, mas uma análise mais detalhada da obra nos mostra que a afinidade com obras influenciadas pelo paradigma da obra de arte é ainda maior. A ausência de modulação na estrutura e uso de elementos pré-fabricados, a preciosidade no detalhamento de revestimentos e escolha de materiais que requerem uma aplicação quase artesanal - como o petit pavé do revestimento externo - demonstram a preocupação do arquiteto em criar um edifício singular, rico em texturas, no qual a iluminação natural participa da composição e valoriza a volumetria. 
9. ANDREA BERRIEL: CASA SCHAITZA

Rua Humberto Bevervanso

Curitiba, Paraná

Arquitetos: Andréa Berriel

Colaboração: Fernando Simas

Projeto: 2003 (?)

Conclusão: 2004

Área: 300,00

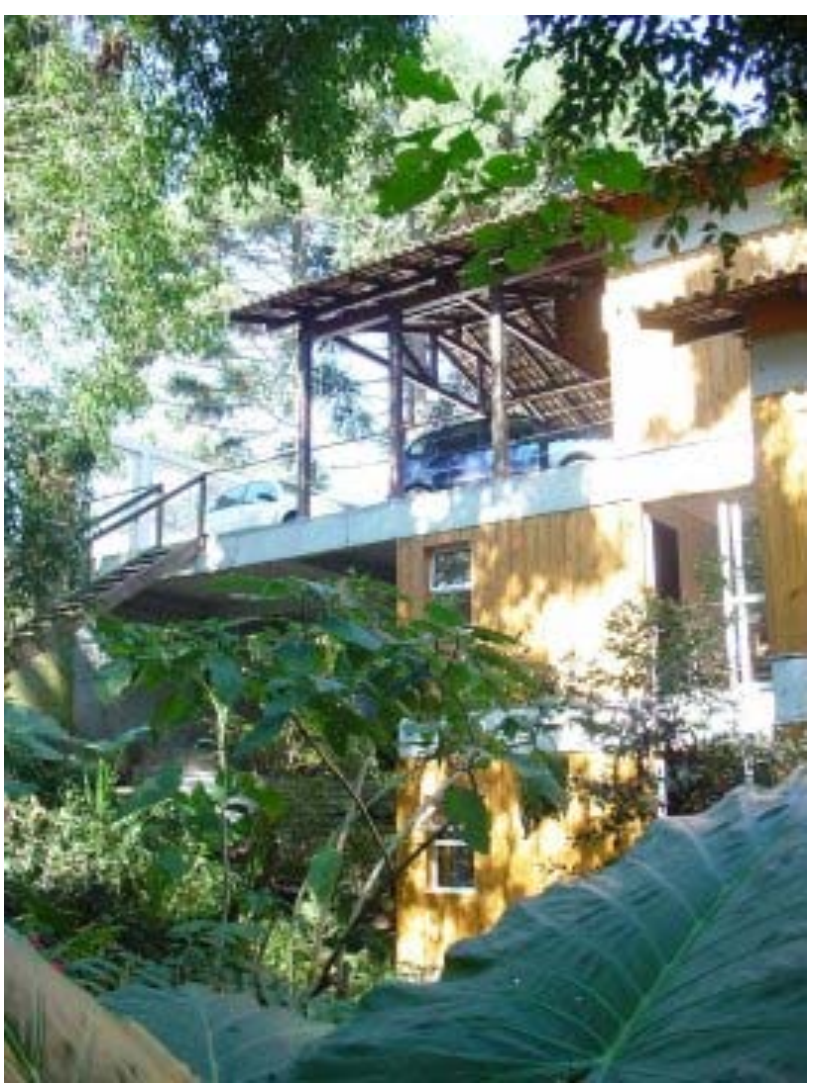

Figura 64 - Casa Schaitza: vista geral 


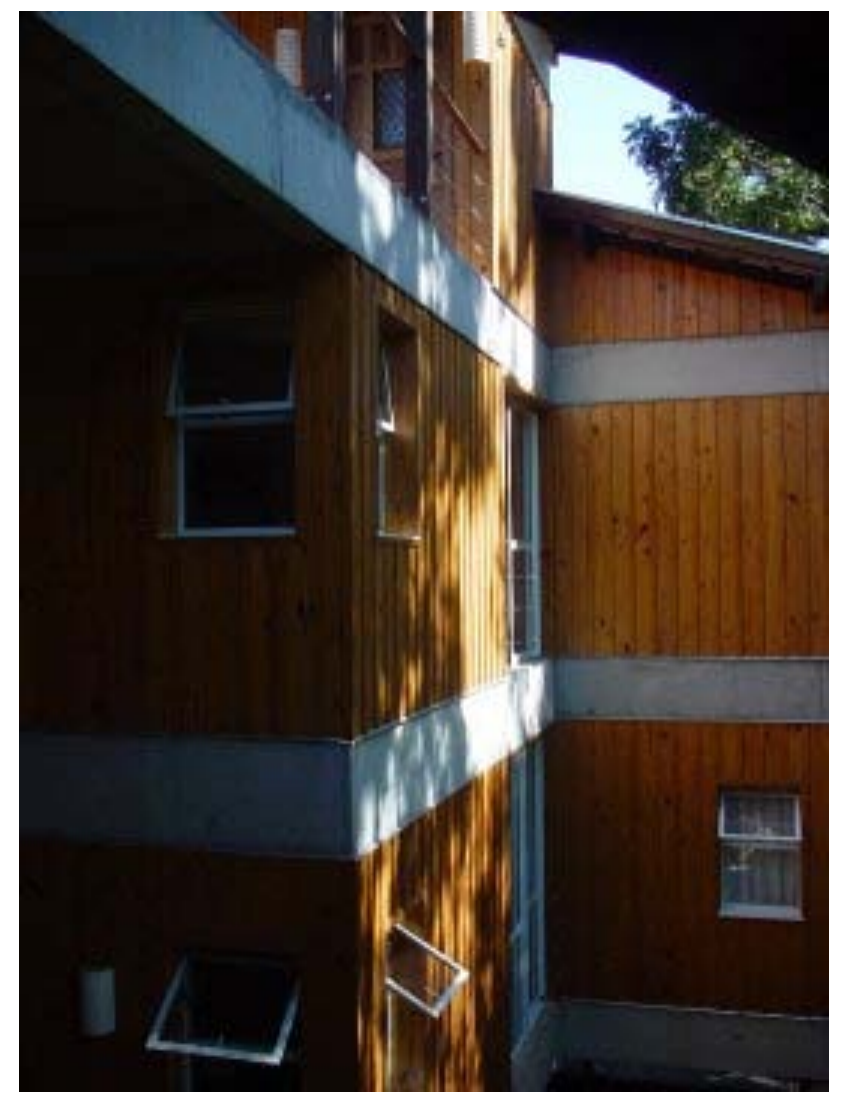

Figura 65 - Casa Schaitza: perspectiva

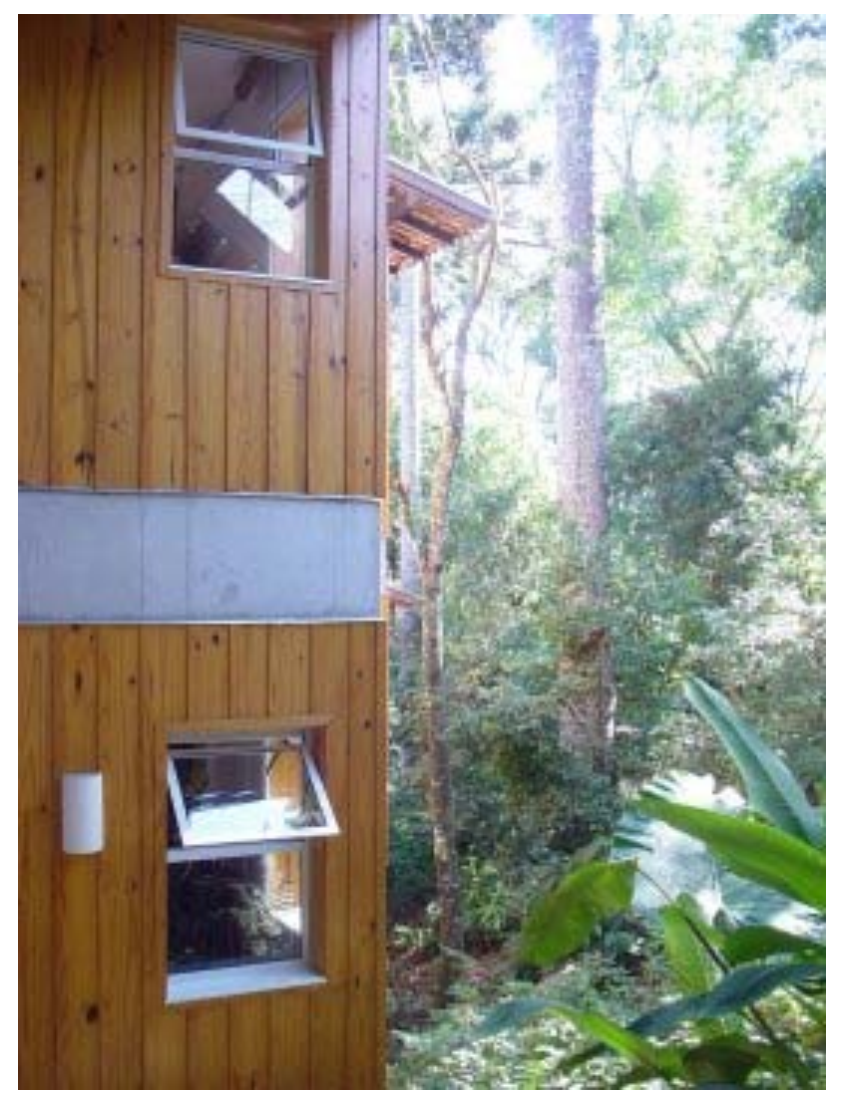

Figura 66 - Casa Schaitza: detalhe aberturas 


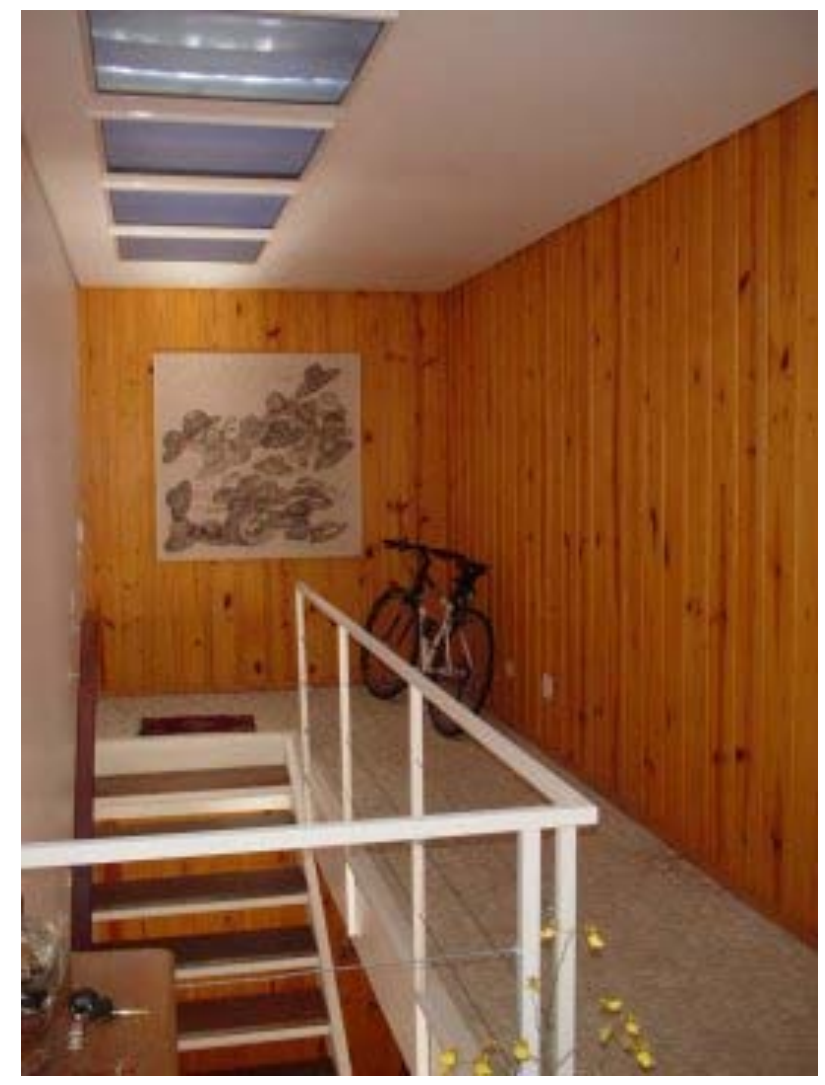

Figura 67 - Casa Schaitza: escada

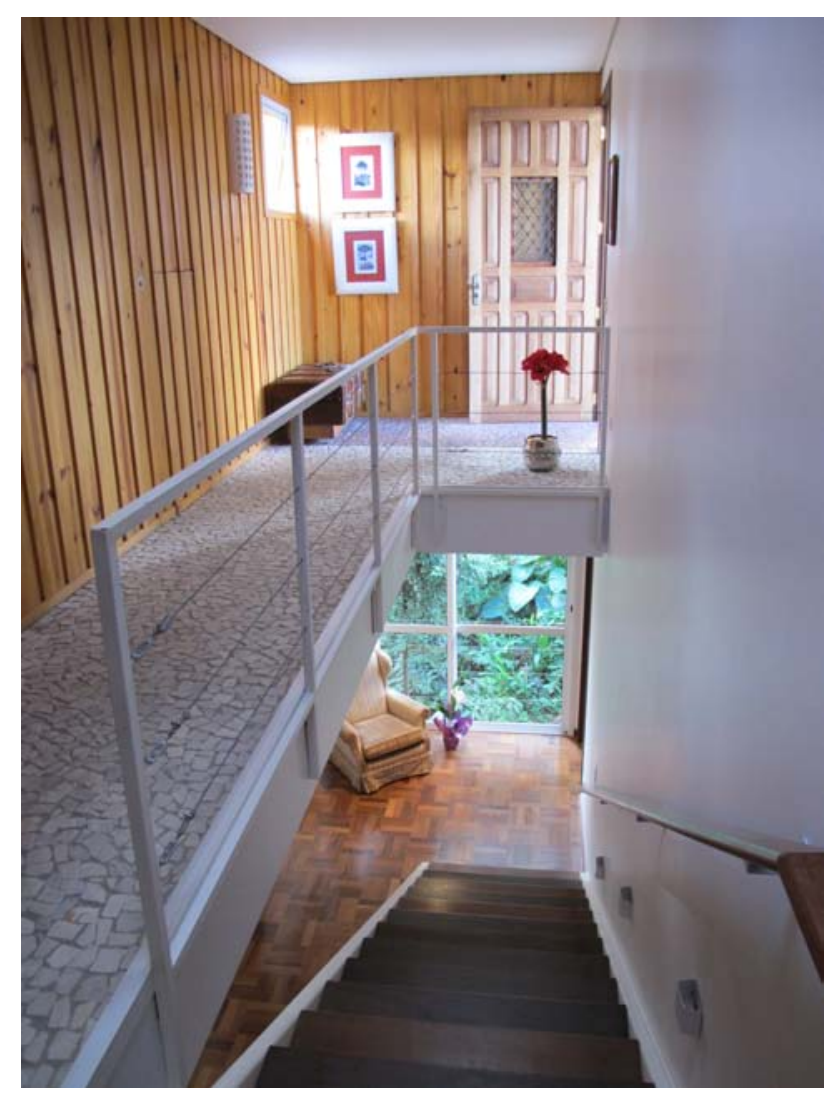

Figura 68 - Casa Schaitza: interior 


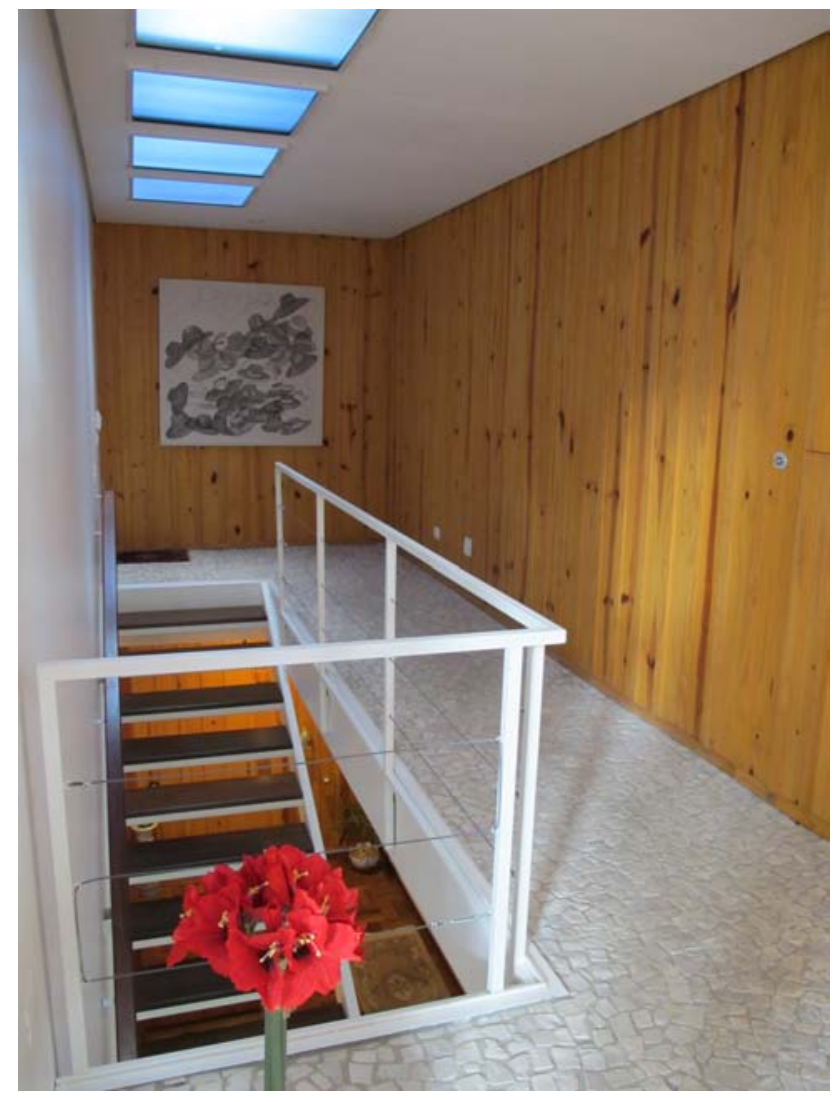

Figura 69 - Casa Schaitza: corredor interno

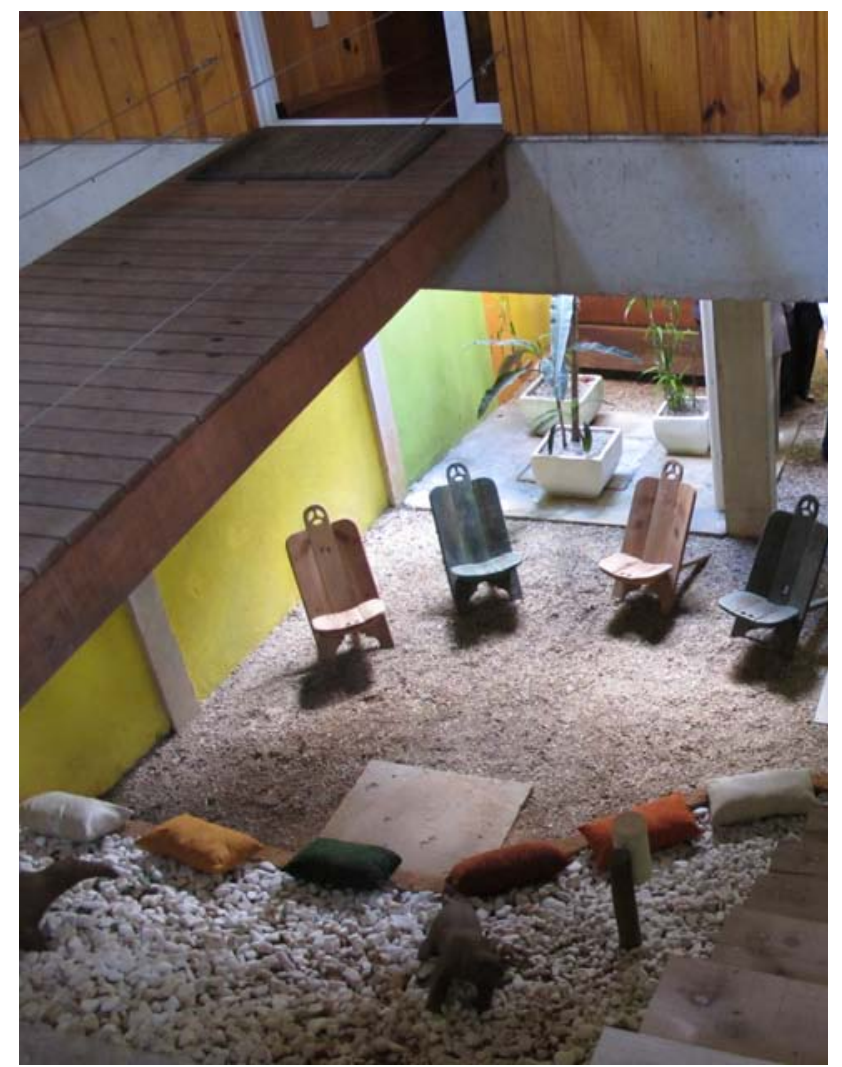

Figura 70 - Casa Schaitza: vista interna 


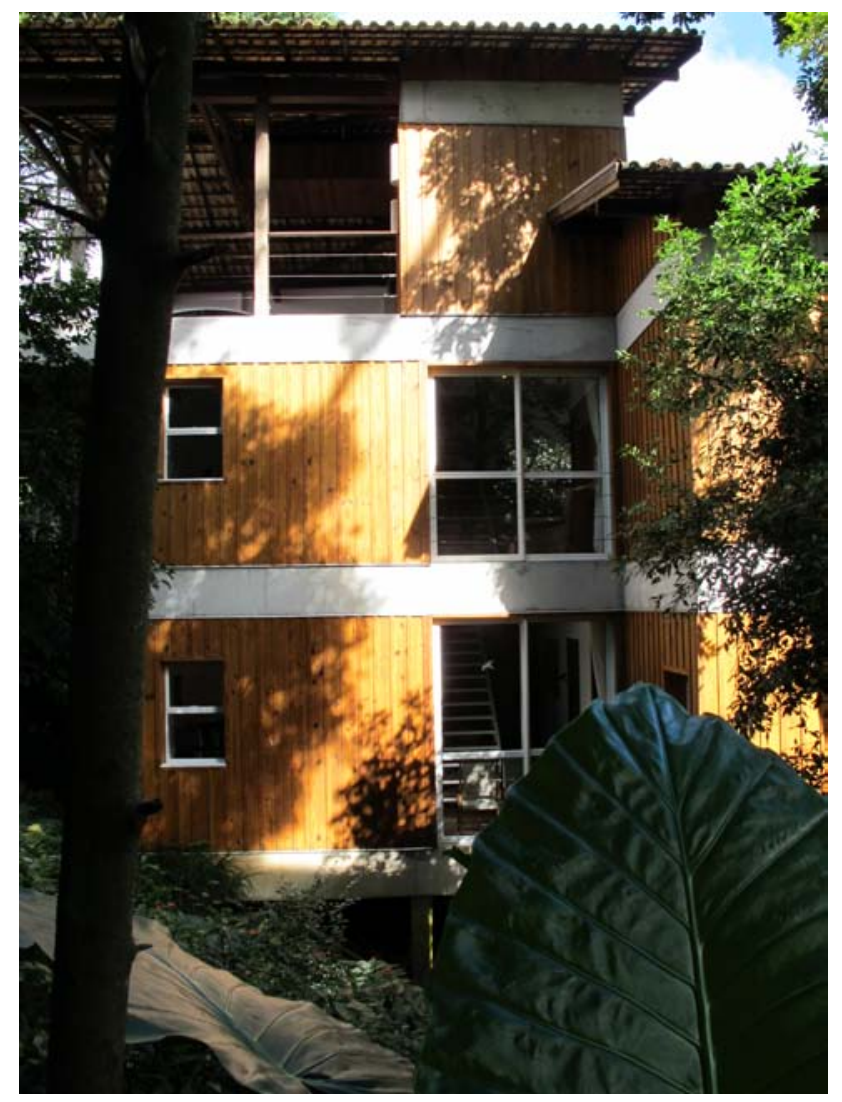

Figura 71 - Casa Schaitza: vista fundos

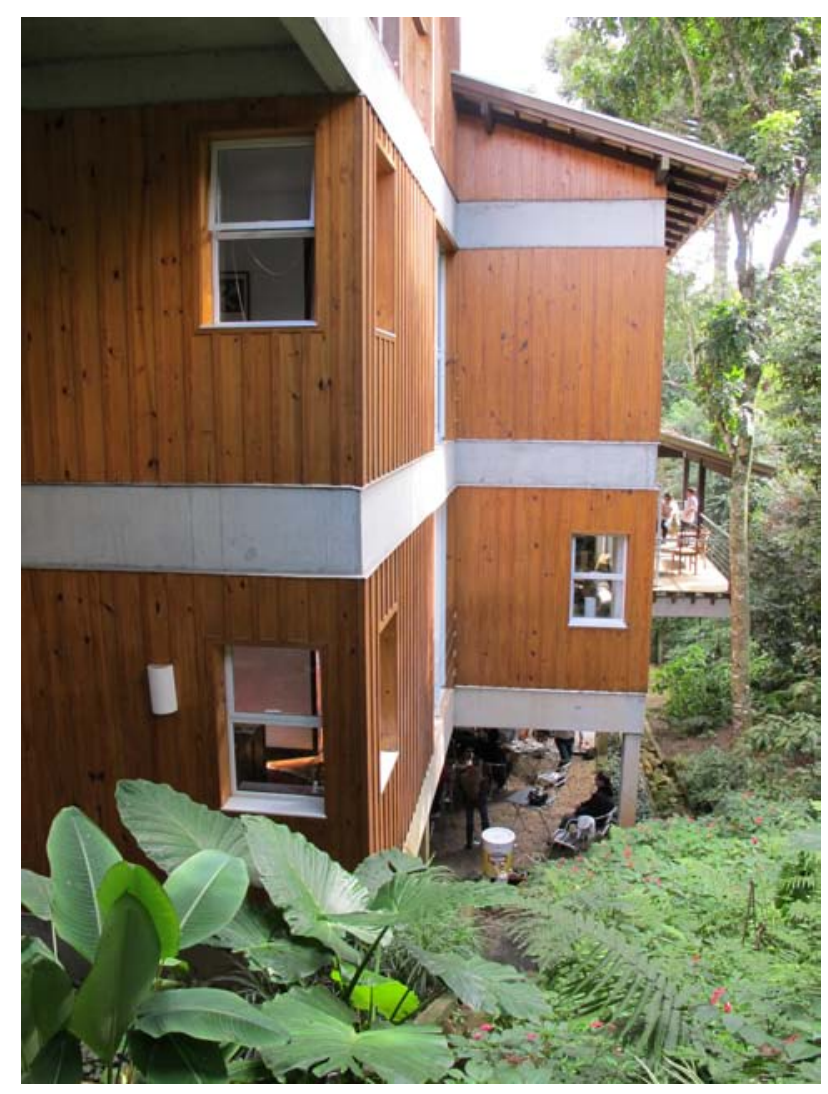

Figura 72 - Casa Schaitza: perspectiva externa 


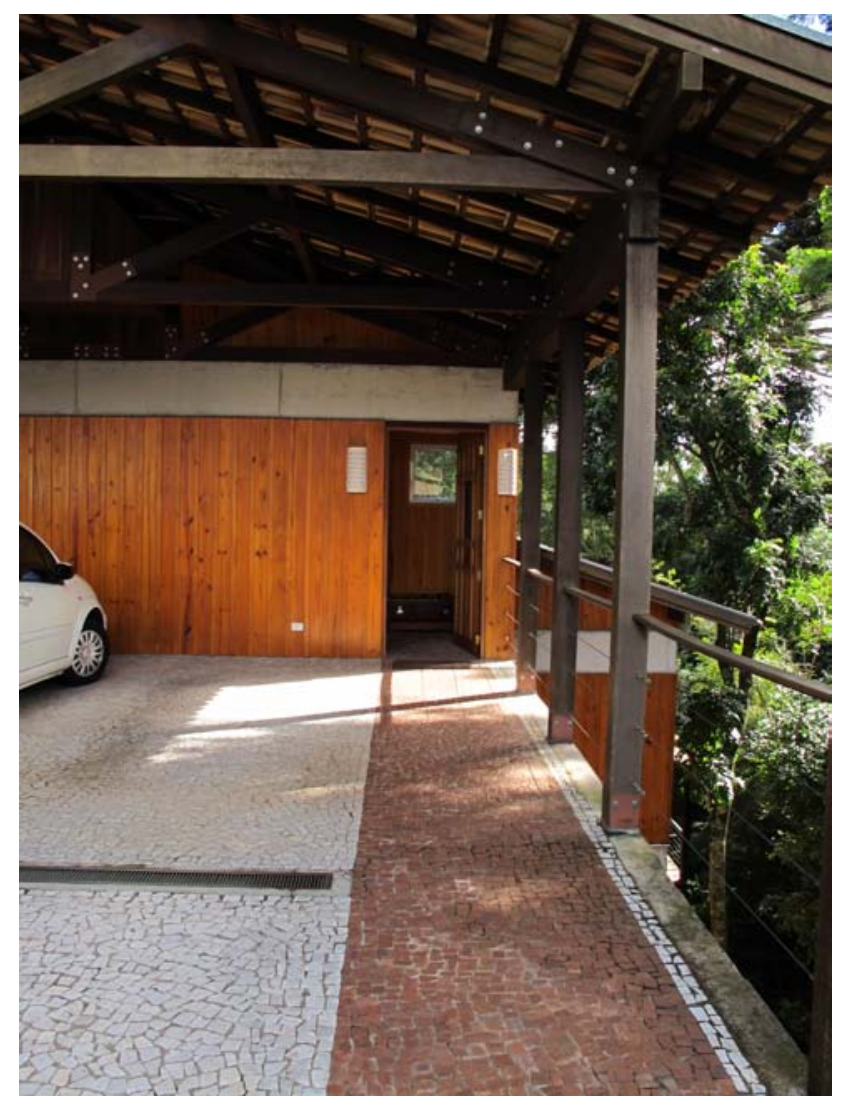

Figura 73 - Casa Schaitza: garagem

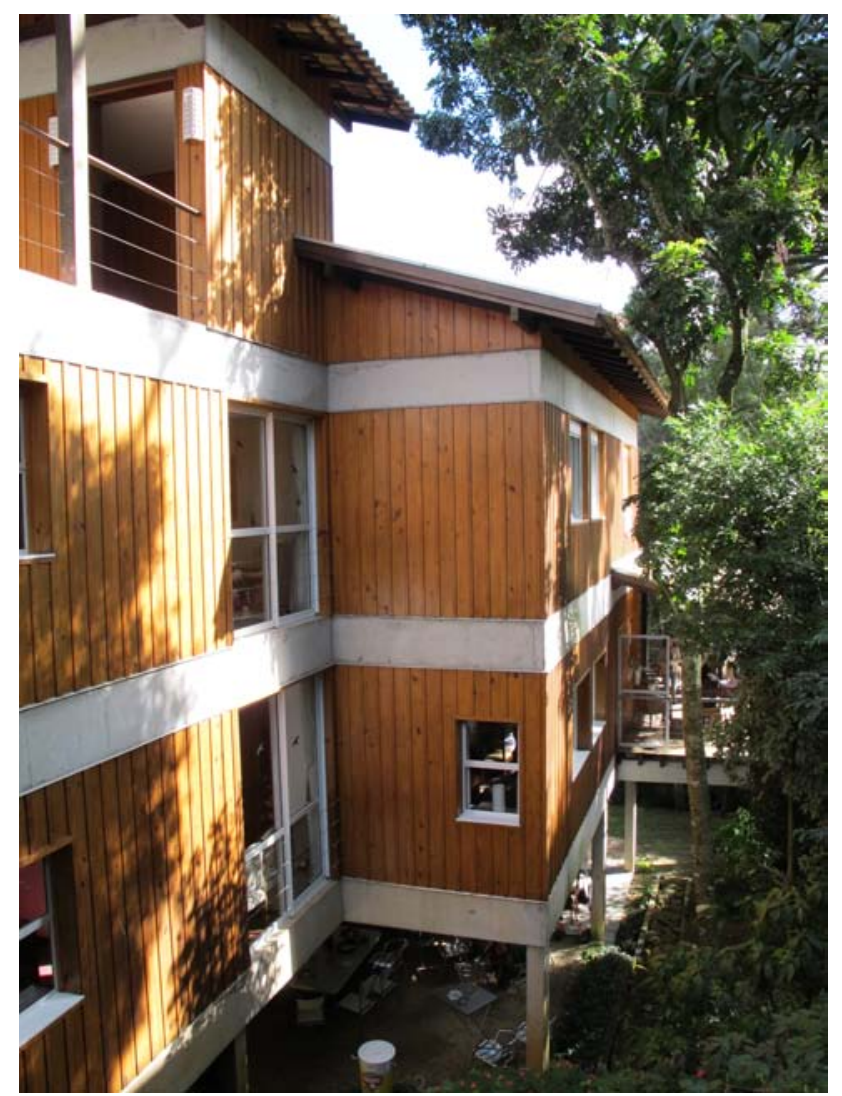

Figura 74 - Casa Schaitza: vista externa 

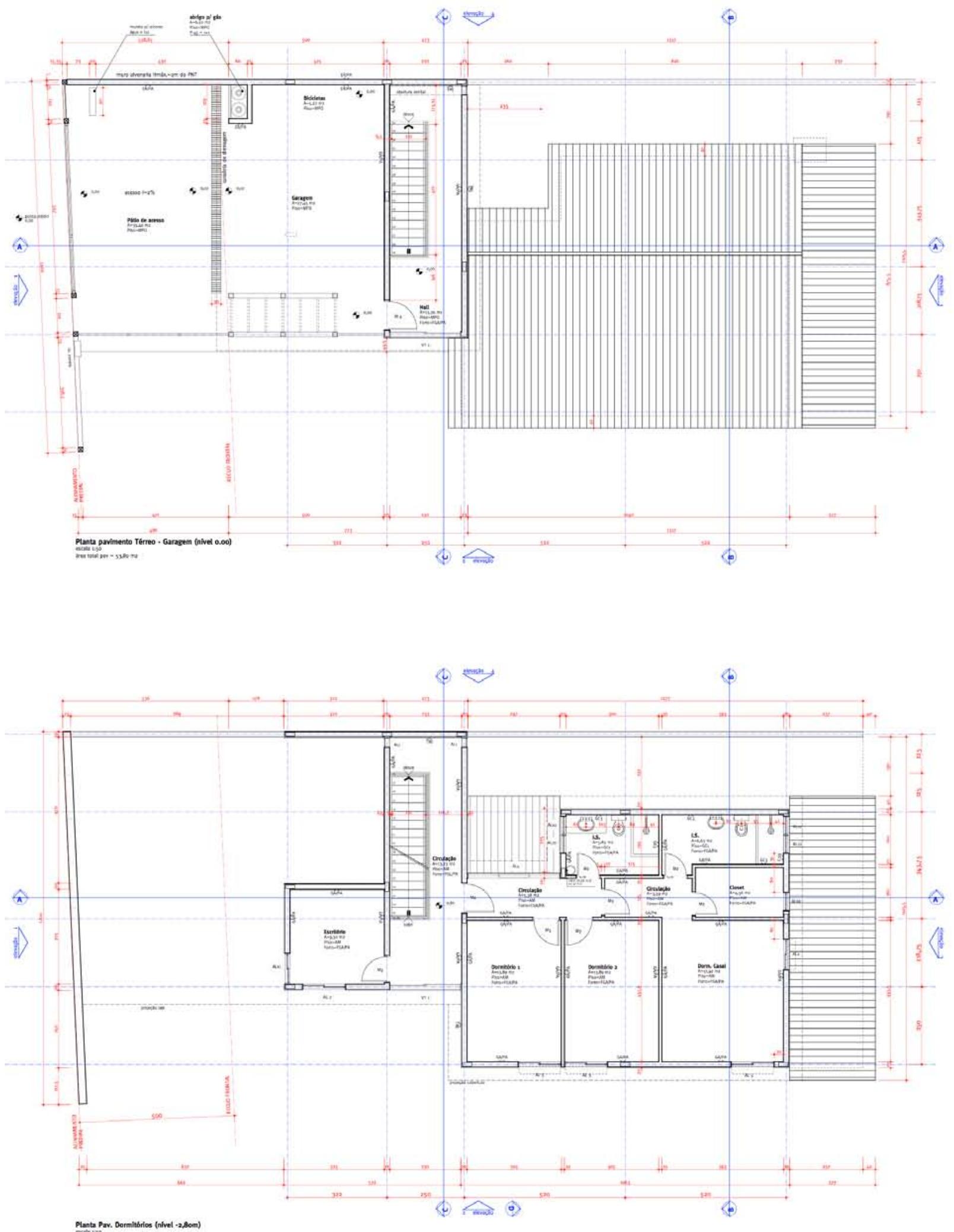

Figura 75 - Casa Schaitza: plantas térreo e primeiro pavimento 

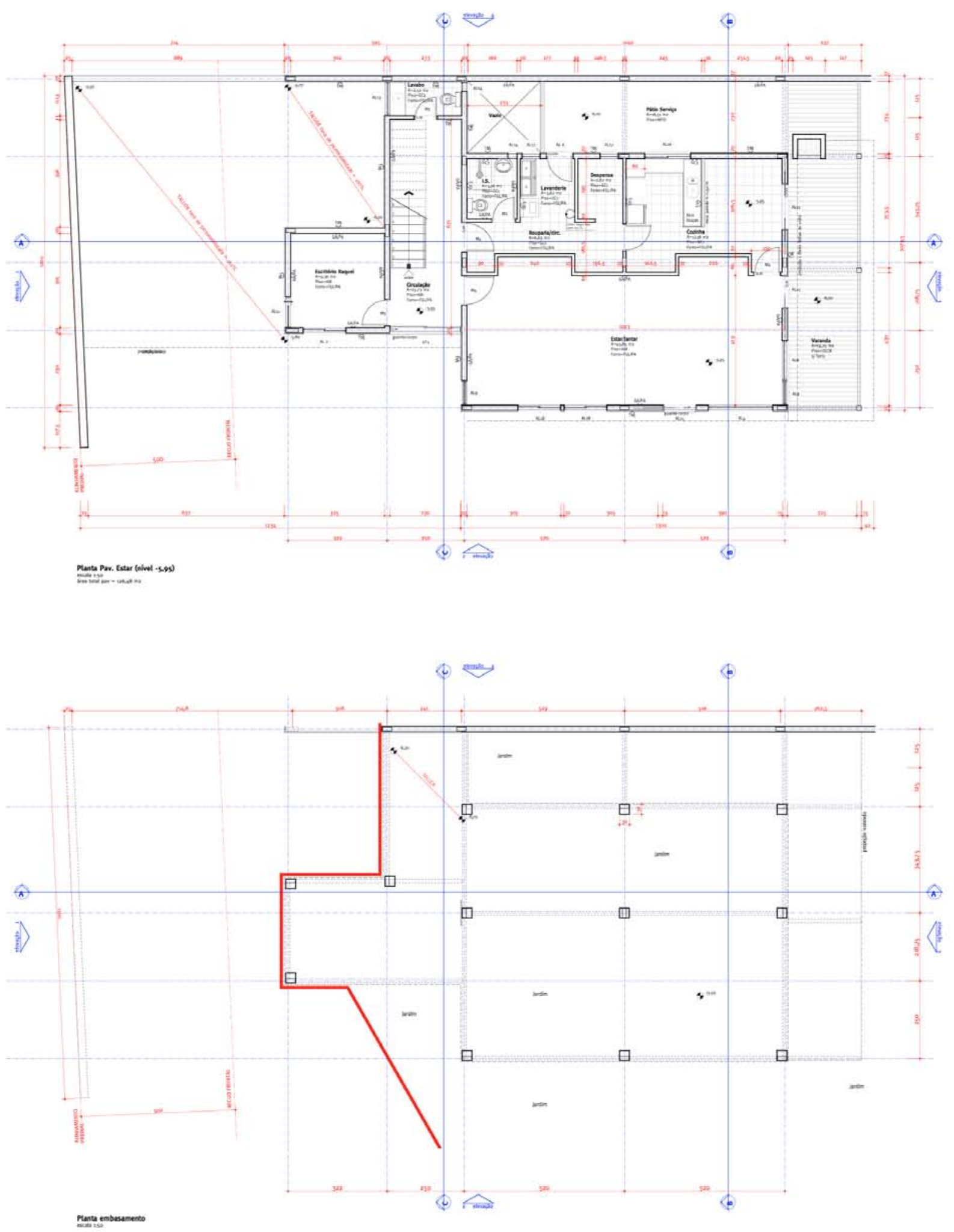

Figura 76 - Casa Schaitza: planta pavimento superior e embasamento 

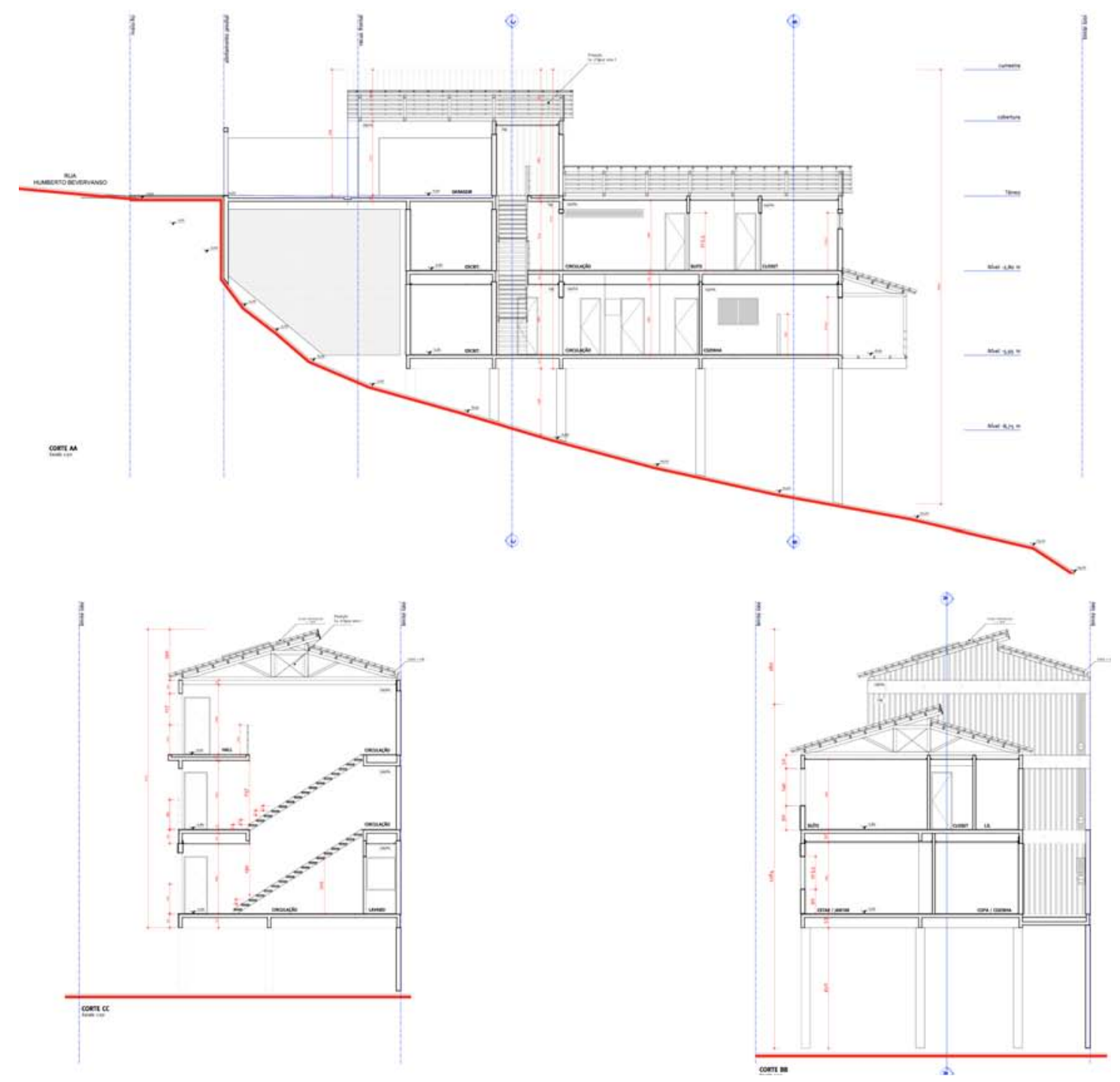

Figura 77 - Casa Schaitza: cortes 

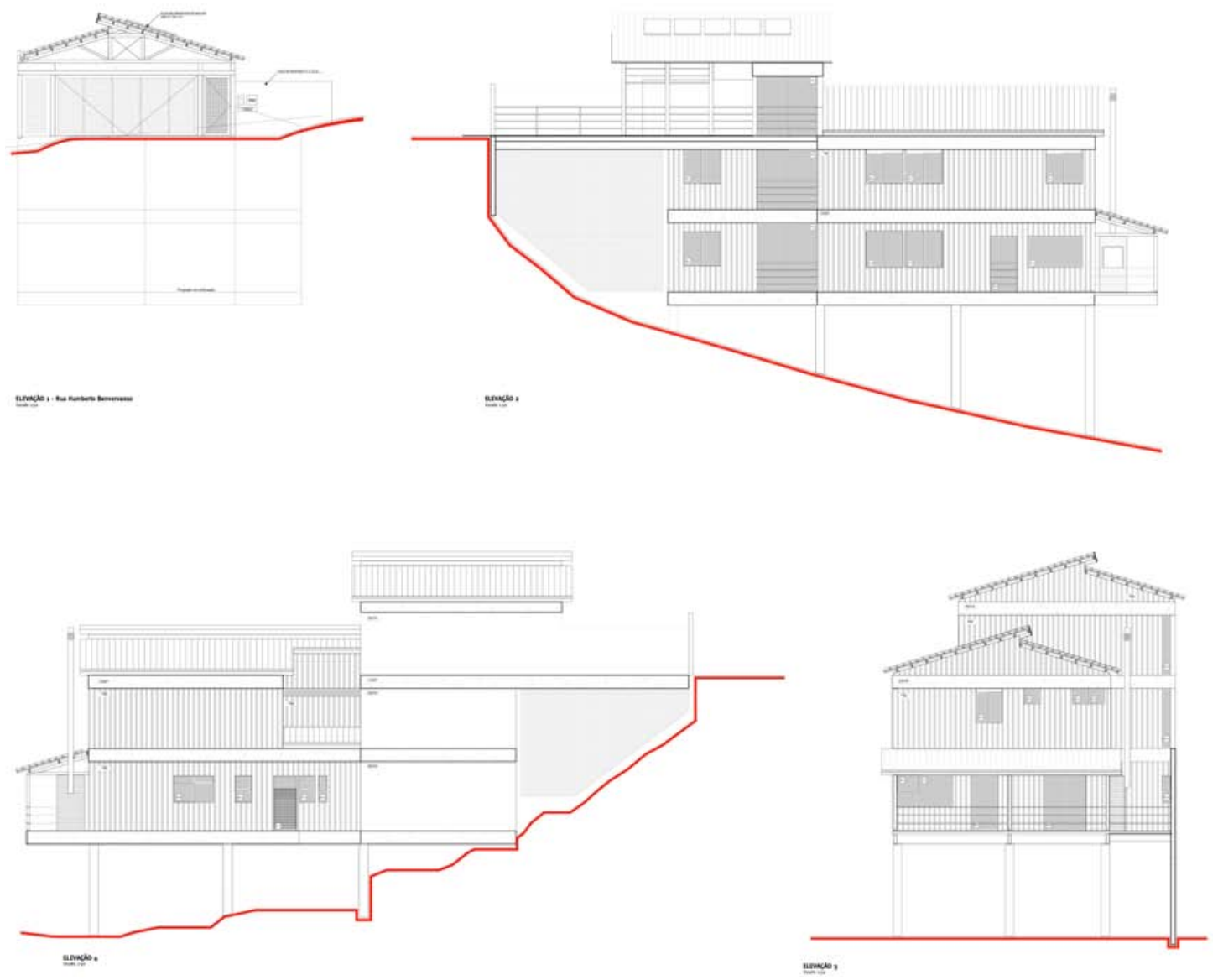

Figura 78 - Casa Schaitza: elevações

\subsection{Visão geral}

A residência foi construída em meio a um bosque, em lote urbano. Com estrutura de concreto armado e vedações de madeira - fechamento vertical em tábua e mata-junta. A obra explora a linguagem contemporânea, através do uso da tecnologia e materiais locais.

O acentuado declive do terreno foi responsável por diversas condicionantes e decisões de projeto. $O$ acesso de veículos e pedestres acontece no pavimento mais alto desta residência de três andares. Os dormitórios estão situados no nível intermediário da construção e as áreas de estar, jantar, cozinha e serviço no pavimento inferior.

A arquiteta levou o petit pavé, piso tradicional das calçadas de Curitiba, para o interior da residência, como revestimento das circulações dos pavimentos superior 
e intermediário. O sistema de fechamento vertical em tábua e mata-junta é característico do exemplar mais significativo da arquitetura de imigração do final do século XIX e primeira metade do século XX no Paraná, a "Casa de Araucária" (IMAGUIRE; 1993) - construção típica da região de mata de araucária, que se estendia pelos estados do sul, mas principalmente pelo Paraná.

\subsection{Implantação e relação com o entorno}

As características originais do terreno foram determinantes na concepção do projeto. A acentuada declividade a partir da rua de acesso e a abundante vegetação do lote foram o ponto de partida para várias soluções de projeto.

Com o objetivo de preservar tanto quanto o possível as características originais do sítio, a arquiteta optou por posicionar o acesso de veículos e pedestres no pavimento superior da residência, assentado na cota mais alta do lote.

Os três dormitórios, banheiros e escritório encontram-se no pavimento intermediário. No pavimento mais baixo, apoiado sobre pilares, encontram-se as áreas sociais e de serviço da residência.

Com relação à orientação, quartos e áreas sociais foram privilegiados com a fachada norte, enquanto instalações sanitárias, área de serviço e cozinha estão voltados para o sul.

A varanda com churrasqueira, voltada para o oeste, integra-se a casa através da área de jantar e da cozinha, e possui uma cobertura para proteger a residência da insolação excessiva.

\subsection{Programa de atividades}

A arquiteta distribui os ambientes da residência em três níveis, a partir do ponto mais alto da cota do lote. Devido ao declive acentuado, mesmo o pavimento inferior fica apoiado sobre pilares, preservando o perfil original do terreno.

O nível mais alto da construção, poucos centímetros abaixo da rua de acesso, possui apenas a garagem e o acesso de pedestres. A partir da garagem, é feito o acesso à área de circulação, que conecta os demais pavimentos da casa. 
No pavimento intermediário, a área de circulação separa o escritório da área íntima da residência, onde se encontram a suíte do casal, com closet e banheiro privativo, e dois dormitórios que dividem um banheiro comum.

O pavimento inferior tem distribuição semelhante: em planta, observamos as áreas de estar e jantar ocupam o lugar correspondente aos quartos, enquanto serviço e cozinha estão na mesma posição dos banheiros. Este pavimento também possui um escritório, posicionado no mesmo local do escritório do pavimento superior. Jantar e cozinha se abrem para uma varanda com churrasqueira, com vista para o denso bosque nos fundos do lote.

\subsection{Partido arquitetônico}

O partido arquitetônico decorre das características originais do sítio e da busca pela plasticidade da tecnologia construtiva e materiais escolhidos. A opção pela estrutura em concreto com vedações em madeira no sistema tábua e matajunta foi o ponto de partida do projeto. Ao colocar estes dois elementos no centro do processo de projeto, identificam-se duas principais tendências arquitetônicas que determinam as decisões projetuais desta residência.

A escolha de materiais e tecnologias relaciona este projeto na linha do debate arquitetônica do contextualismo cultural. Pela preocupação com as características naturais do sítio, preservação da mata nativa, aproveitamento dos ventos e insolação do local, pode-se notar a influência dos estudos relacionados com a sustentabilidade na arquitetura.

A declividade acentuada do terreno e a densa vegetação do entorno levaram a arquiteta a optar por uma solução suspensa, independente da topografia original e apoiada sobre pilares de concreto.

O fechamento vertical em madeira relembra as construções típicas da arquitetura de imigração do final do século XIX e início do século XX no Paraná. As esquadrias em alumínio se repetem nos pavimentos da construção, trazendo ritmo e modulação à composição. 


\subsection{Sistema construtivo}

A obra foi construída com pilares de concreto armado e fechamento em madeira. As tábuas de pinus que fazem a vedação da construção foram posicionadas no sentido vertical, com largura de $20 \mathrm{~cm}$ e mata-junta de $5 \mathrm{~cm}$.

A cobertura é em duas águas com inclinação de 30\%, em estrutura de madeira e telha portuguesa. As aberturas zenitais trazem luz natural para o interior da casa, principalmente na área de circulação. As esquadrias são em alumínio com pintura eletrostática branca.

O piso do pavimento térreo - garagem e circulação - é revestido com petit pavé branco. o piso dos quartos, estar e jantar da residência, em tacos de madeira tatajuba. As áreas úmidas - banheiros, cozinha e área de serviço - possuem revestimento cerâmico.

\subsection{Intenção Plástica}

A plasticidade desta residência decorre dos materiais utilizados na sua concepção. A arquiteta busca a plasticidade através da exposição dos materiais e técnicas construtivas utilizadas no projeto, evidenciando a maneira como o prédio foi construído.

A obra divide-se em dois blocos: o bloco de acesso, com um único pavimento correspondente a garagem da residência, e um segundo bloco, de dois pavimentos, englobando os demais ambientes da casa e que se adapta a declividade do terreno.

A intenção plástica deste projeto é pensada no sentido de uma integração da obra com o entorno, e não do edifício como objeto individual. Toda a composição da residência é pensada em relação ao meio onde esta está inserida, confundindo-se com este através do uso de materiais que tornam a casa parte da natureza ao redor.

Obra e natureza se confundem e se complementam, numa relação simbiôntica não observada em nenhuma das residências analisadas até então. 


\section{Z ARQUITETURA (SLOMP BUSARELLO): CASA JAERR}

Rua Eduardo Sprada, 2388 - Condomínio Burgel

Curitiba, Paraná

Arquitetos: Dilva Slomp Busarello, Orlando Busarello, Daniela Slomp Busarello

Colaboração: Danielle B. Ribeiro, Valmir Caviquilo

Projeto: 2005

Conclusão: 2007

Construtora: Macioro Construção Civil

Área: 440,00

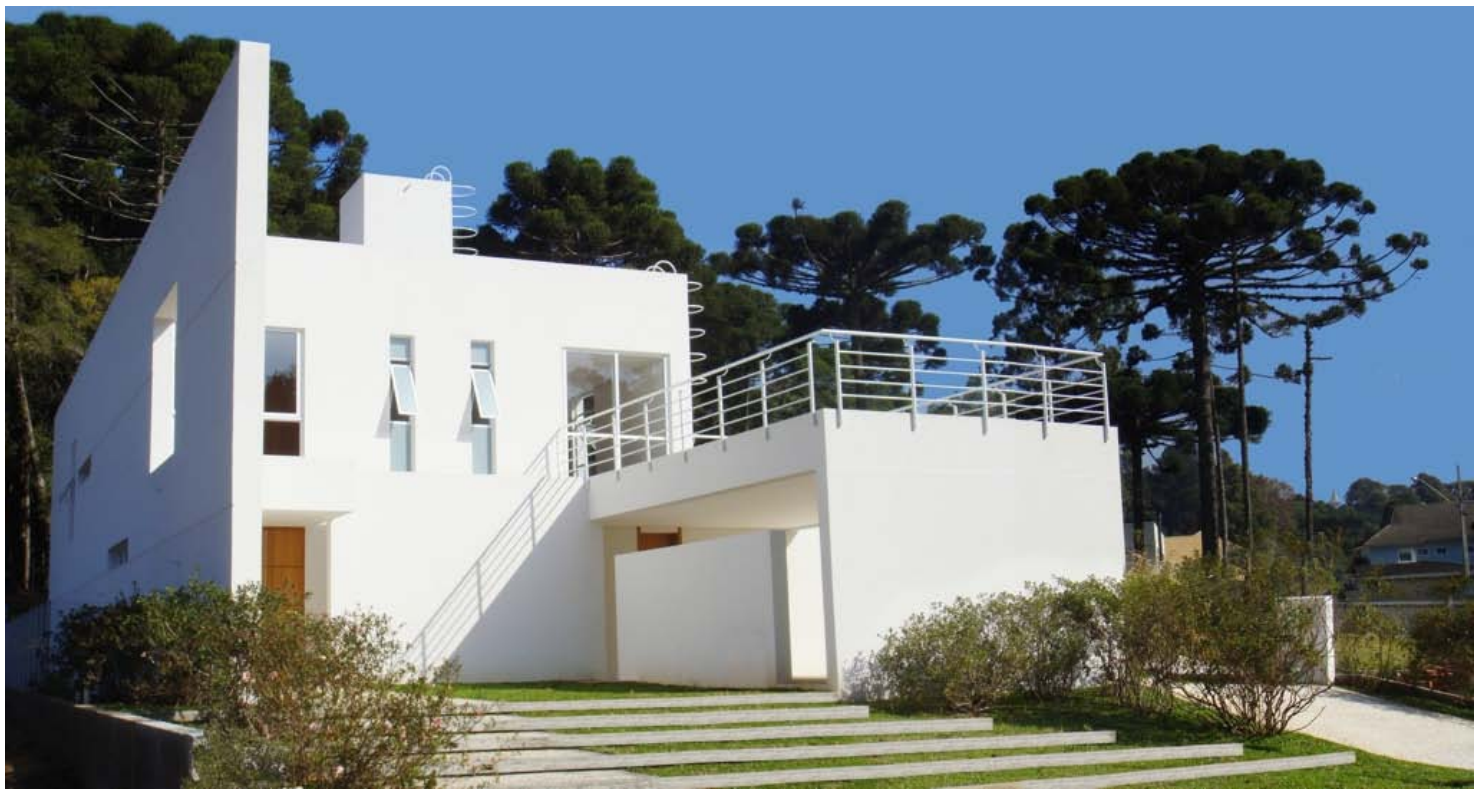

Figura 79 - Casa JAeRR: perspectiva externa

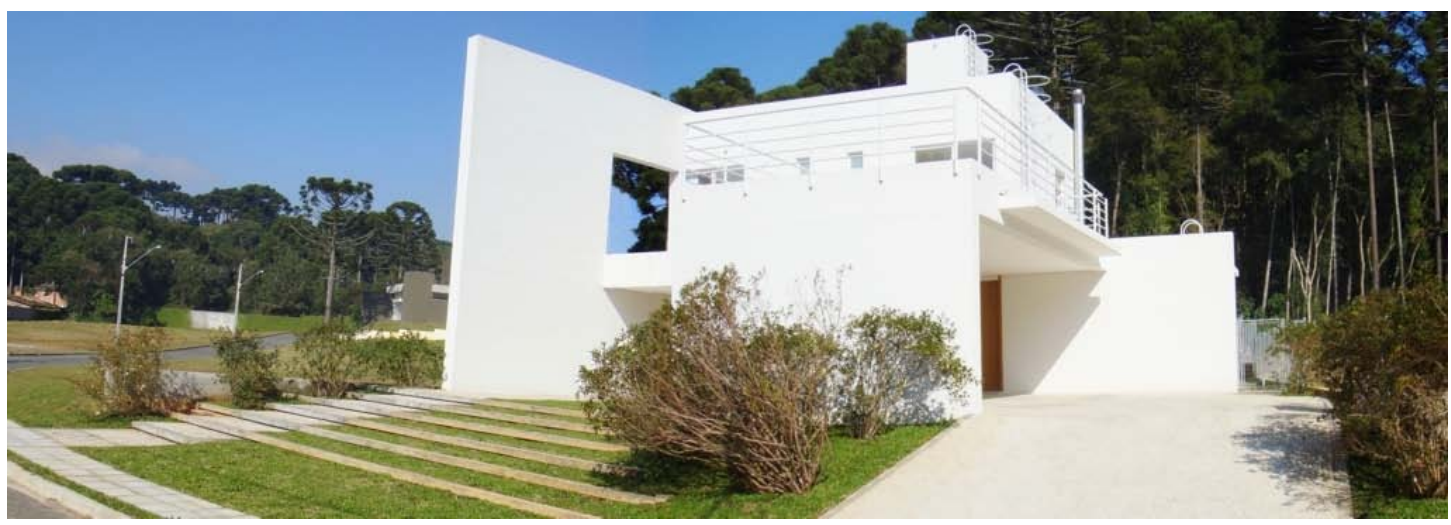

Figura 80 - Casa JAeRR: vista geral 


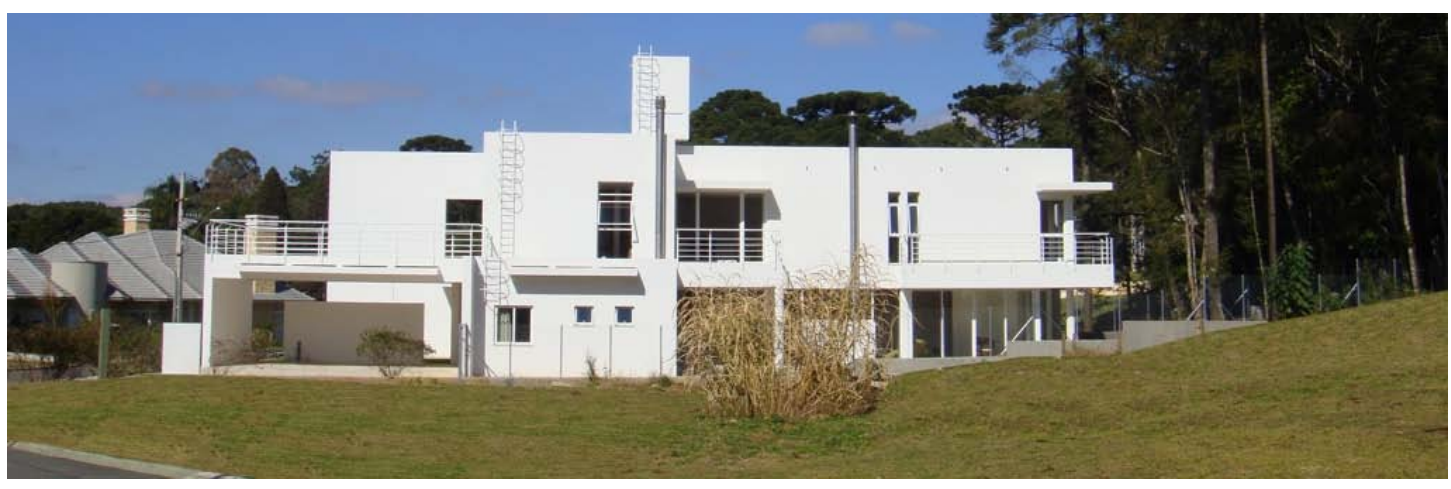

Figura 81 - Casa JAeRR: elevação lateral

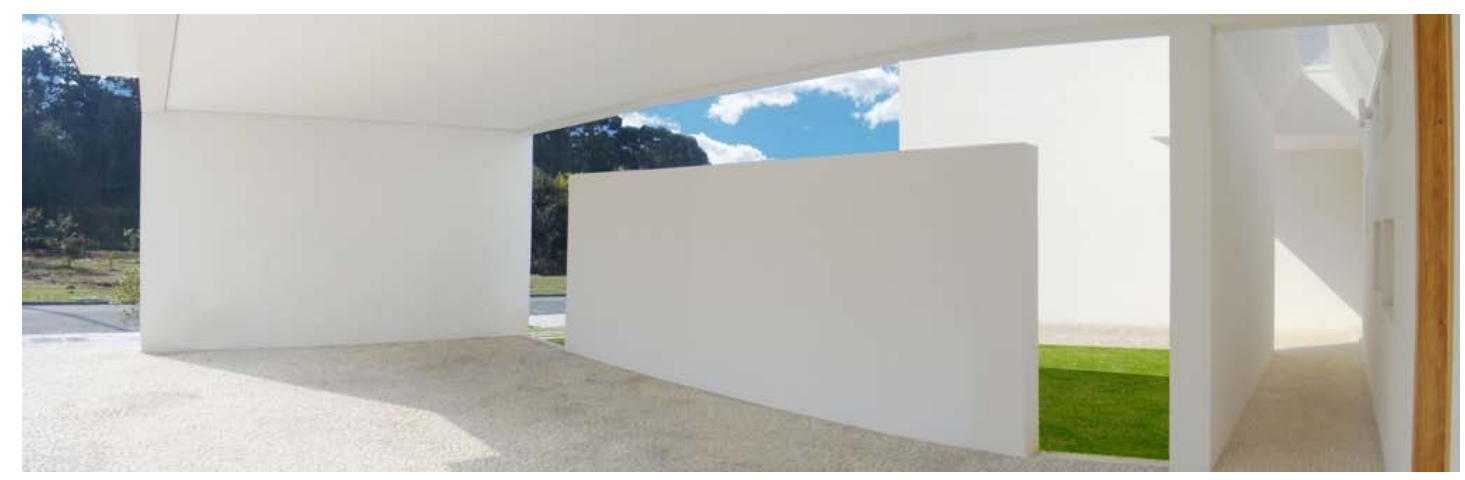

Figura 82 - Casa JAeRR: plano garagem

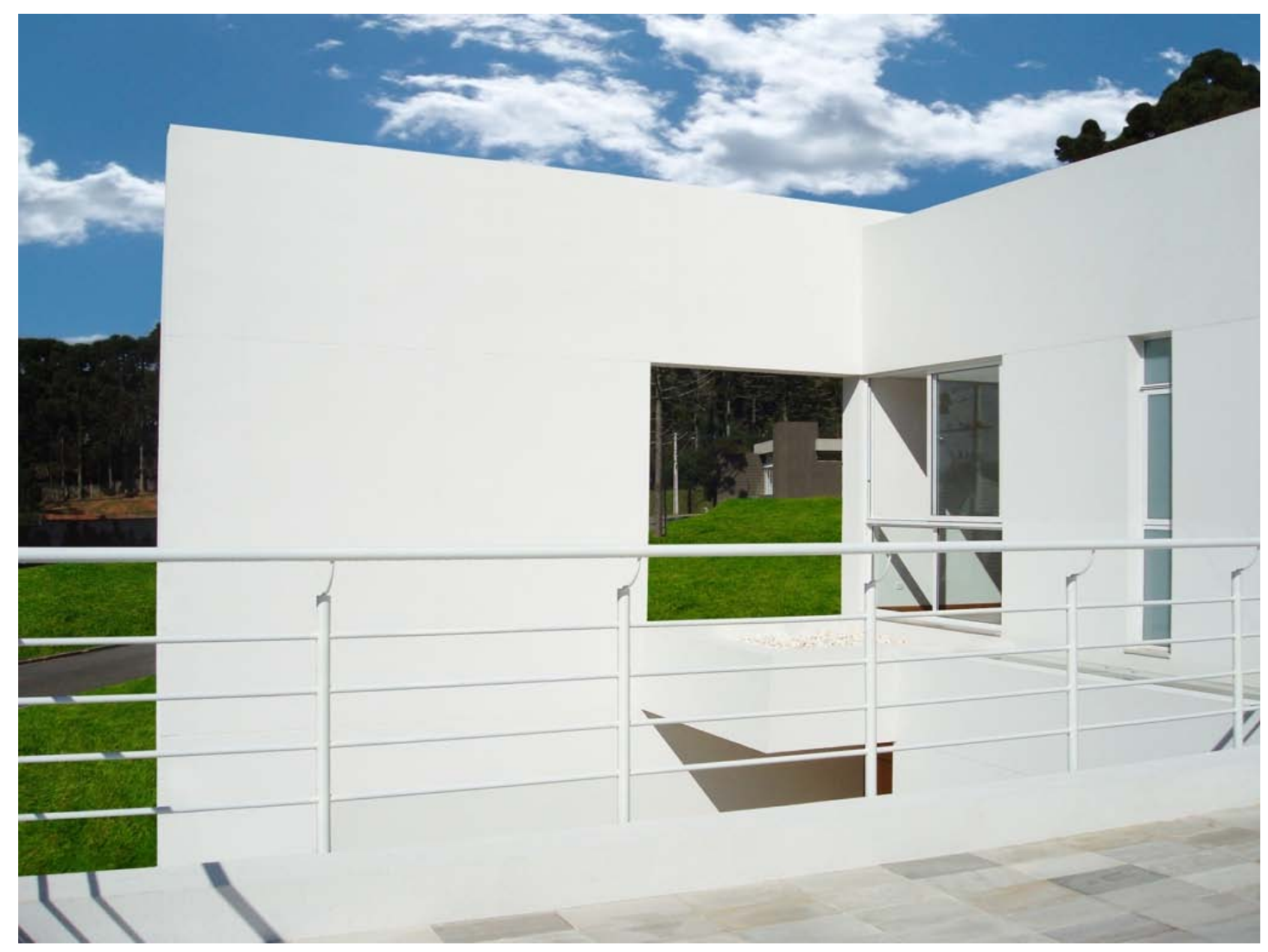

Figura 83 - Casa JAeRR: vista terraço 


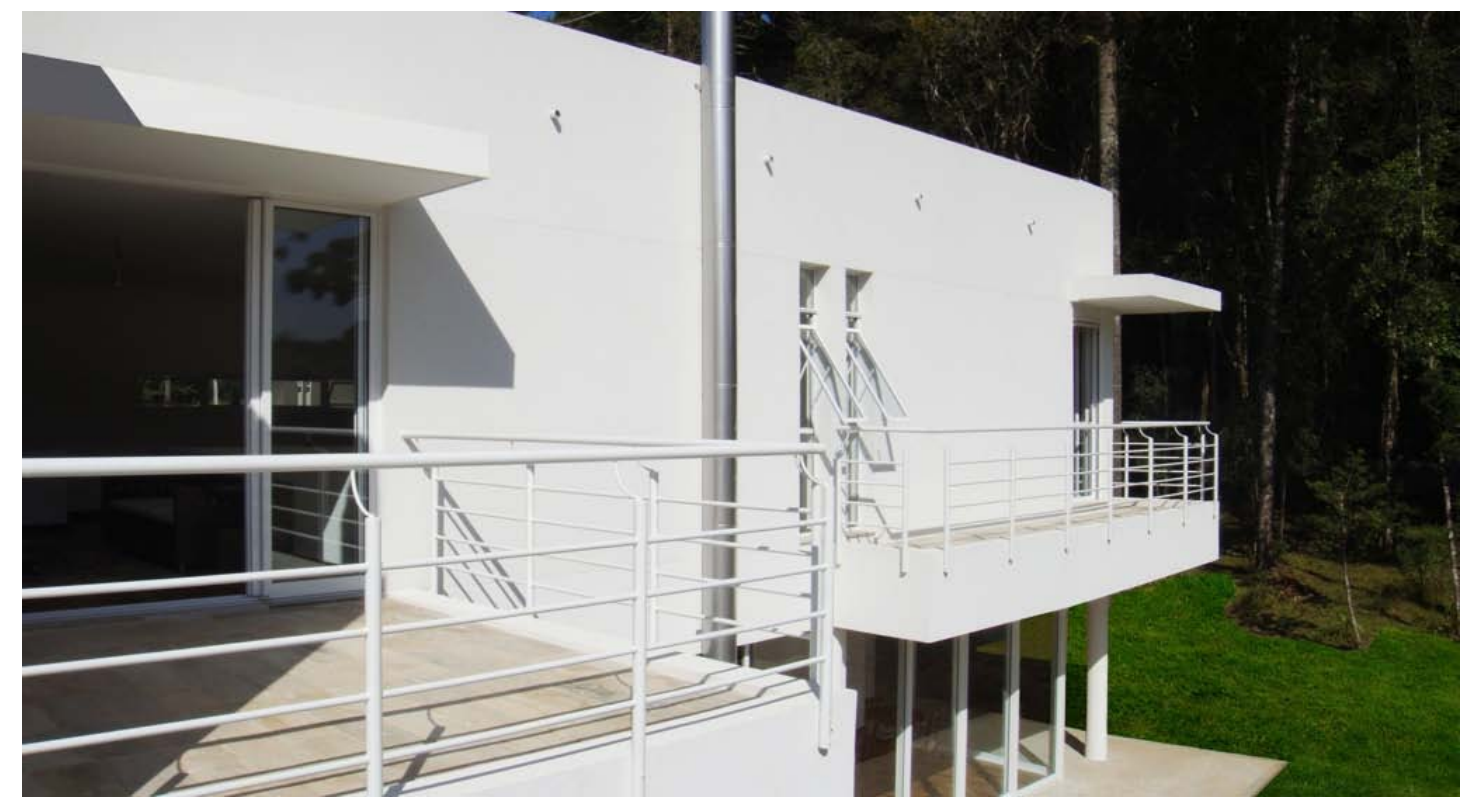

Figura 84 - Casa JAeRR: terraços

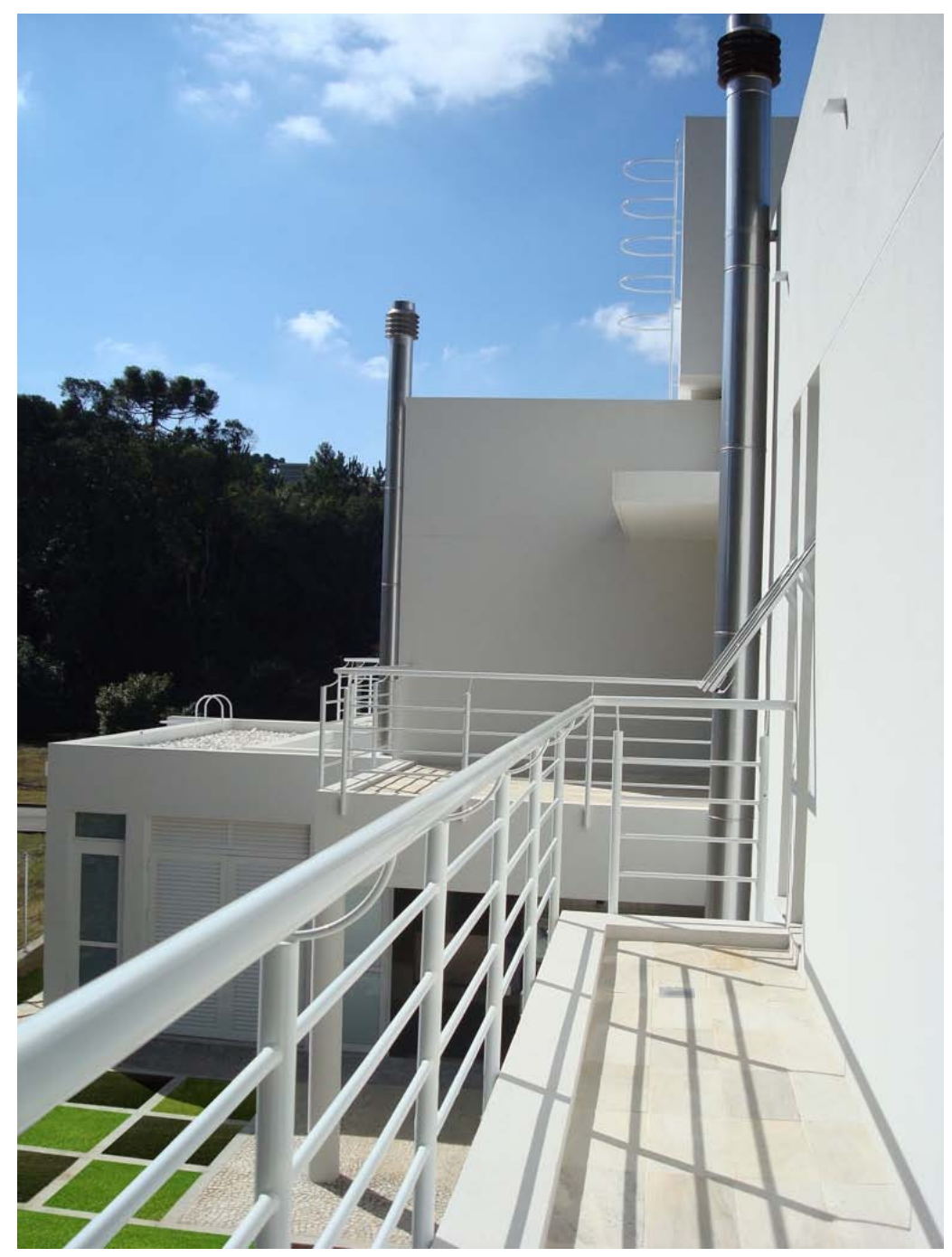

Figura 85 - Casa JAeRR: vista externa / detalhe piso jardim 


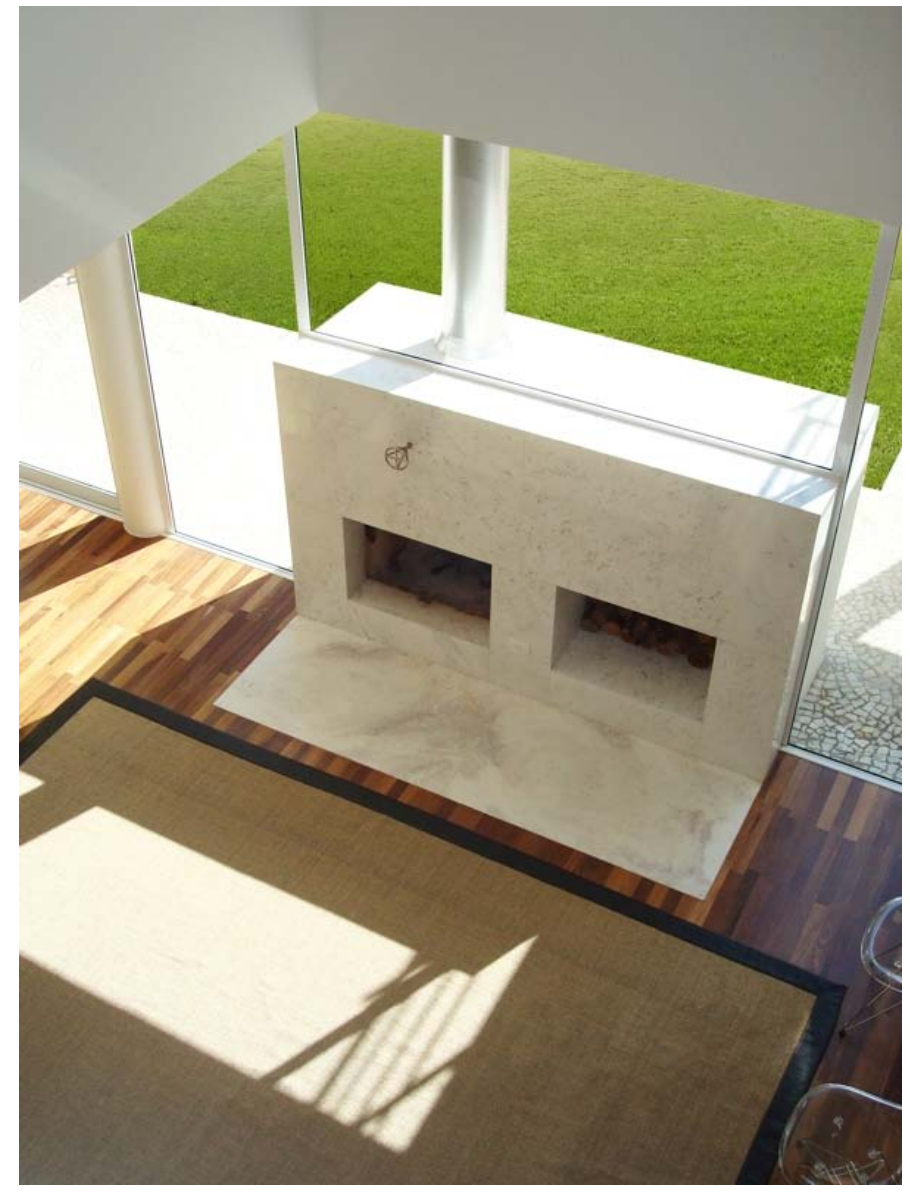

Figura 86 - Casa JAeRR: detalhe lareira

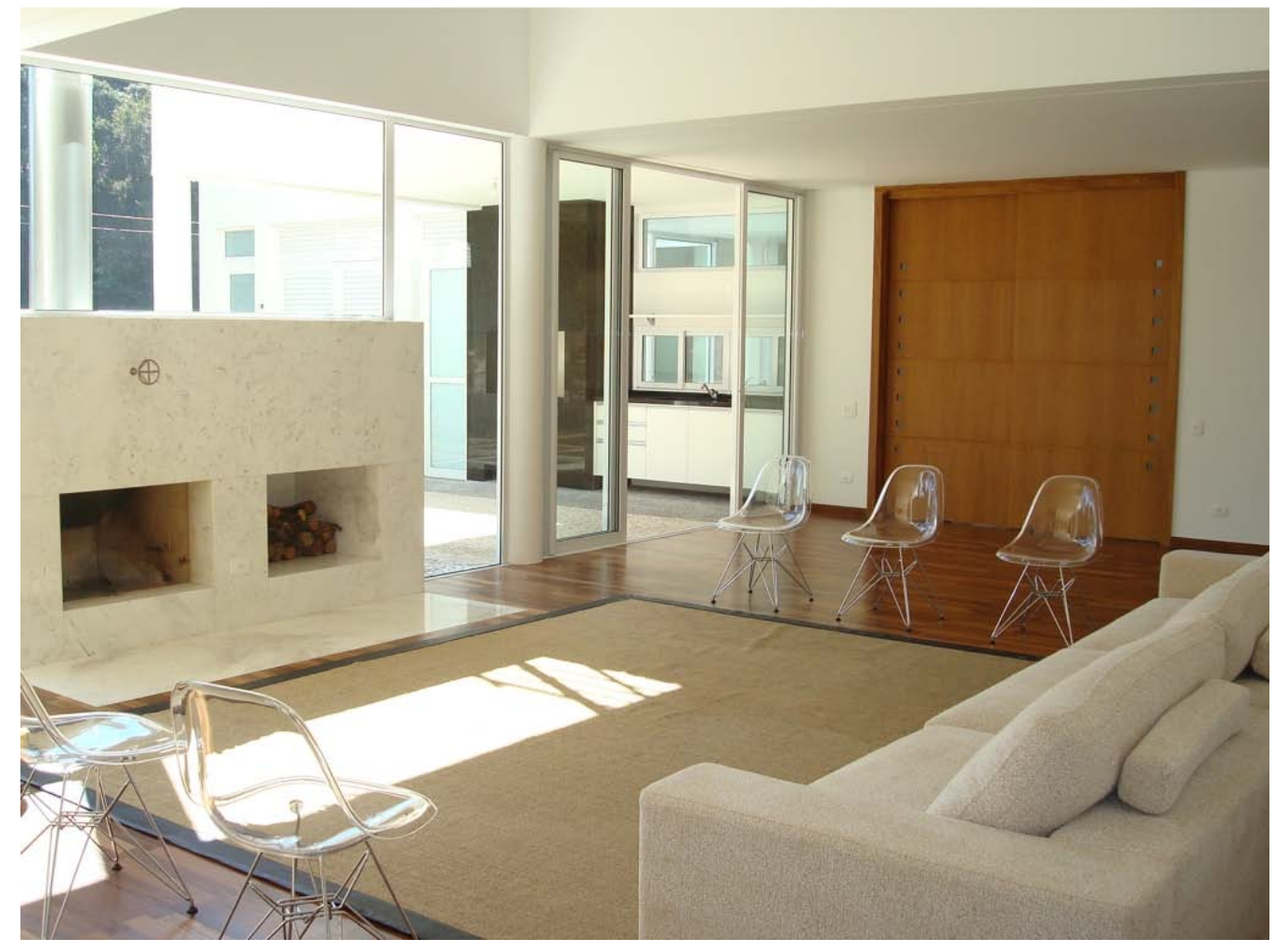

Figura 87 - Casa JAeRR: estar 


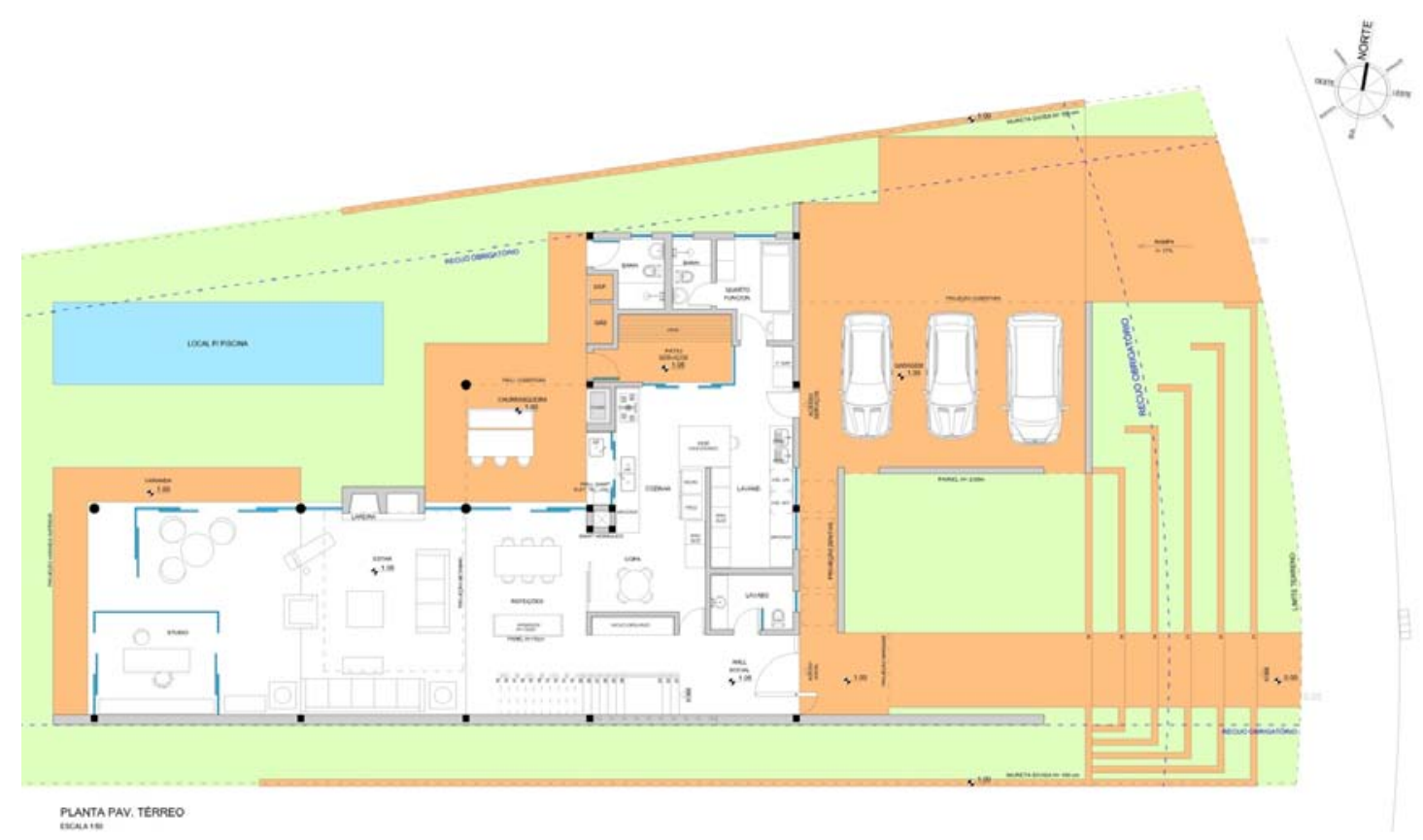

Figura 88 - Casa JAeRR: planta pavimento térreo

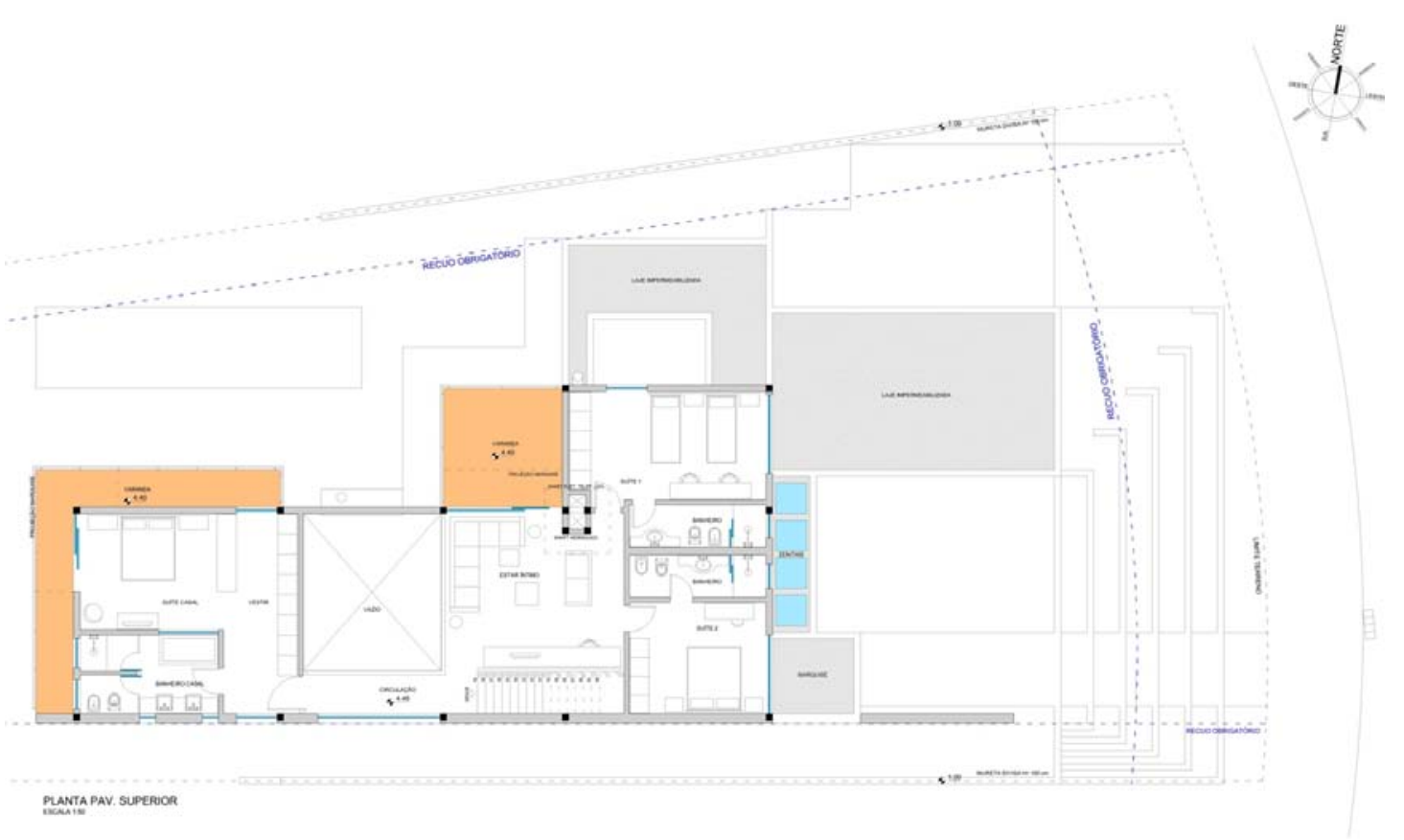

Figura 89 - Casa JAeRR: planta pavimento superior 

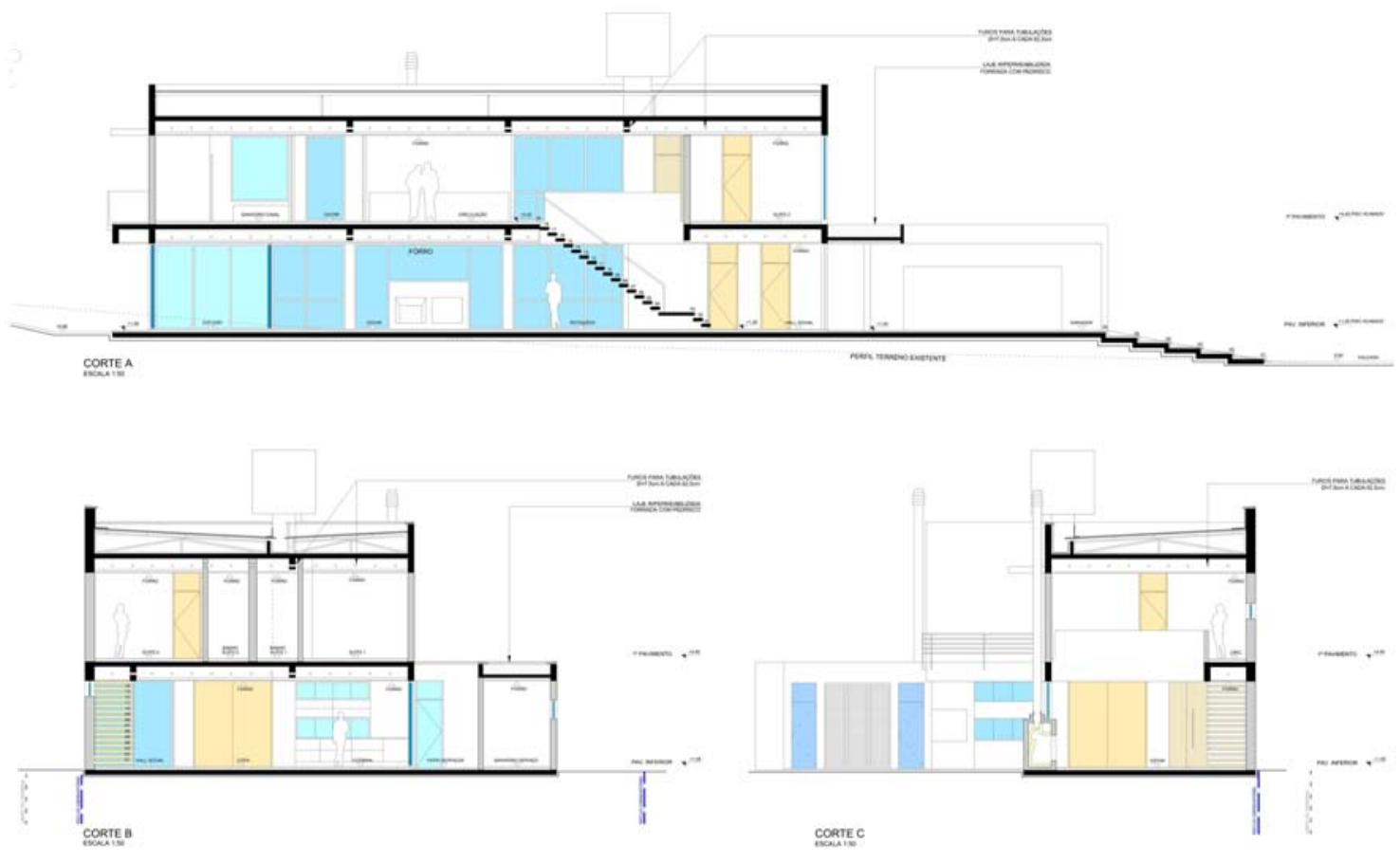

Figura 90 - Casa JAeRR: cortes

\subsection{Visão geral}

Esta casa de $440 \mathrm{~m} 2$ caracteriza-se pela distribuição de volumes que se articulam a partir de um grande plano de alvenaria branca, praticamente sem aberturas, voltado para a fachada sul. $\mathrm{O}$ acesso social acontece paralelamente a este grande plano, pelo lado leste da edificação.

A forma alongada da obra possibilitou um bom aproveitamento da fachada norte, permitindo que, praticamente, todos os dormitórios e áreas de estar da residência tirassem proveito dessa orientação.

A área social da casa se interliga com o jardim e piscina, através de grandes planos de vidro, proporcionando a sensação de continuidade espacial e integração entre interior e exterior. Da mesma forma, no pavimento superior, varandas e terraços estendem-se a partir dos planos que definem os contornos da residência. Um recorte no plano da fachada sul emoldura a visual do entorno a partir do terraço principal. 


\subsection{Implantação e relação com o entorno}

Situada em um terreno de esquina e com pouca declividade, dentro de um condomínio fechado, a residência se impõe afirmativamente sobre a paisagem, adotando uma distribuição em planta que não somente tira proveito das melhores visuais do sítio, mas também emoldura e enquadra a perspectiva do entorno a partir da obra construída.

O projeto da casa tem origem na orientação das fachadas, buscando sempre o posicionamento adequado dos ambientes e aberturas de forma a garantir o conforto térmico e explorar as visuais do entorno.

As áreas sociais da casa - voltadas para o norte - se abrem através de portas-janela envidraçadas para ambientes externos a construção, como churrasqueira e piscina. Desta forma, estes ambientes funcionam como um espaços de transição entre o interior da residência e o jardim, possibilitando que estar e jantar se estendam para fora dos limites da residência.

\subsection{Programa de atividades}

O projeto se divide em dois pavimentos, sendo o térreo destinado às áreas sociais e de serviço, enquanto o segundo pavimento abriga a área íntima da casa. A residência possui dois acessos: o social, feito a partir da rua, por uma escada de grandes patamares que leva ao hall social da casa; e o de serviço, feito através da garagem coberta, que se conecta diretamente com a lavanderia.

As áreas sociais do térreo configuram um espaço único e contínuo, com o uso diferenciado apenas pelo mobiliário de cada ambiente. A área de serviço é ampla e possui um dormitório e instalação sanitária para funcionários.

A churrasqueira possui um banheiro próprio, acessado a partir do exterior da residência, e uma bancada de serviços que se liga diretamente com a cozinha através de um passa-pratos.

$\mathrm{O}$ acesso aos segundo pavimento é feito pela escada localizada no hall social, que leva a um estar íntimo, com ampla varanda com vista para a piscina/jardim. A suíte principal tem orientação norte e uma varanda com vista para o 
jardim. O pavimento possui duas suítes menores, uma voltada para norte e a outra para o leste.

\subsection{Partido arquitetônico}

O partido arquitetônico decorre da orientação do terreno e aproveitamento da fachada norte da residência. A construção se desenvolve a partir de um plano contínuo e praticamente sem aberturas voltado para a fachada sul. Esse plano opaco possibilita a privacidade da construção sem que haja a necessidade de um muro separando o terreno da residência da rua lateral.

A residência se abre para o jardim interno, com orientação norte, onde foram posicionados piscina e churrasqueira. A configuração longilínea da casa em planta possibilita que a maioria dos ambientes sociais e quartos da residência estejam voltados para o norte, orientação que favorece a insolação destes ambientes e com vista para o jardim.

Pode-se observar no projeto uma preocupação em separar as áreas da casa - social, íntimo e serviços. A área social é marcada pela continuidade espacial e pela possibilidade de expansão e integração com o jardim. Cozinha e lavanderia estão isoladas da área social e possuem um acesso próprio. Já os quartos, situados em outro pavimento, possuem estar íntimo e se conectam com os ambientes de serviço sem passar pela área social.

\subsection{Sistema construtivo}

O sistema construtivo é bastante simples, associando pilares em concreto com alvenaria na cor branca. Toda a estrutura fica oculta sob o mesmo revestimento das vedações, dificultando sua identificação. Internamente, os pilares ficam escondidos dentro das paredes e todo o vigamento fica oculto sob o forro dos pavimentos.

Não existe uma modulação básica na malha estrutural, contudo existe a correspondência dos pilares no primeiro e segundo pavimentos. As vigas possuem furos a cada $62,5 \mathrm{~cm}$ para facilitar a passagem de tubulações. 
A residência possui um shaft hidráulico e outro shaft para elétrica e telefonia, facilitando a manutenção das instalações. O volume principal possui cobertura em telha e estrutura metálica, definida por duas águas inclinadas em direção a uma calha central. $\mathrm{O}$ volume da garagem e as marquises são em laje impermeabilizada forrada pedriscos.

\subsection{Intenção Plástica}

O projeto é marcado pelo rigor formal e uso de linhas retas bem definidas. A residência é resultado da articulação de planos que se destacam do grande volume principal.

O plano que define a fachada sul se estende além do volume da construção, demarcando o acesso de pedestres e garantindo a privacidade deste em relação à rua lateral. Uma abertura neste plano na altura correspondente a uma janela do pavimento superior "emoldura" o entorno para quem observa a partir da varanda dos quartos.

O espaço da garagem é delimitado pela continuidade da laje do segundo pavimento, que se estende pelo comprimento suficiente para abrigar até três carros, e depois se dobra em direção ao solo, configurando um "L" vazado marcante na volumetria. Um painel de 2 metros de altura "descolado" das outras superfícies separa o acesso de veículos do acesso de pedestres.

O uso da cor branca em toda a volumetria e a ortogonalidade das formas revela uma postura de implantação racionalista em relação ao meio, sugerindo a influência da arquitetura corbusiana. Contudo, a plasticidade obtida pelo jogo de planos, o aspecto escultórico da arquitetura e especialmente a maneira como o arquiteto trabalha a iluminação natural e o jogo de luz e sombra no interior da construção remetem a tendências, demonstra a identificação deste projeto com abstração formal, em particular com a arquitetura do norte-americano Richard Meier. 
11. CENTRAL DE PROJETOS: RESIDÊNCIA NUNES

Rua Professor Francisco Basseti Junior n`351

Curitiba, Paraná

Arquitetos: André Luis Nunes

Projeto: 2004

Conclusão: 2006

Área: 475,00

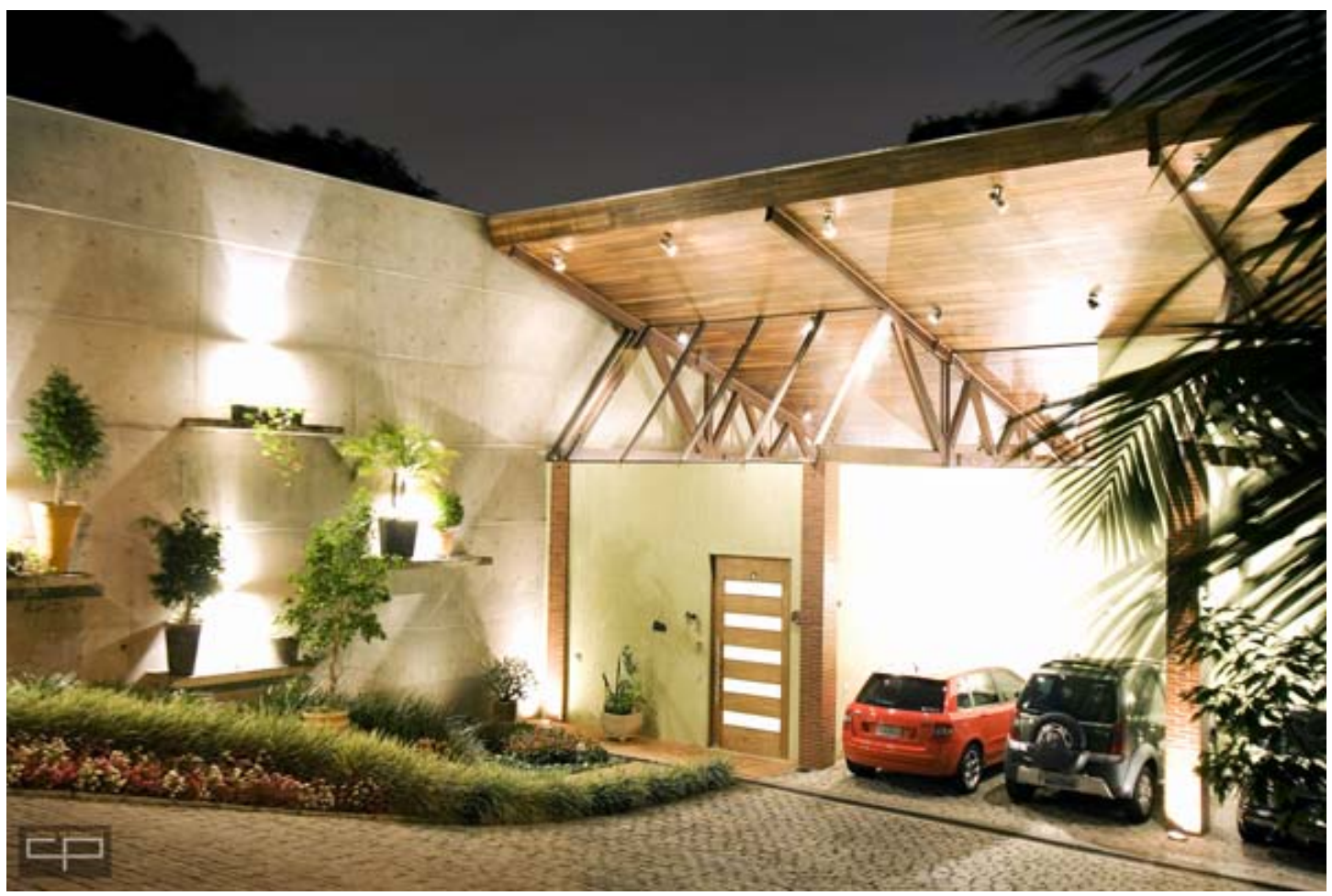

Figura 91 - Residência Nunes: acesso principal 


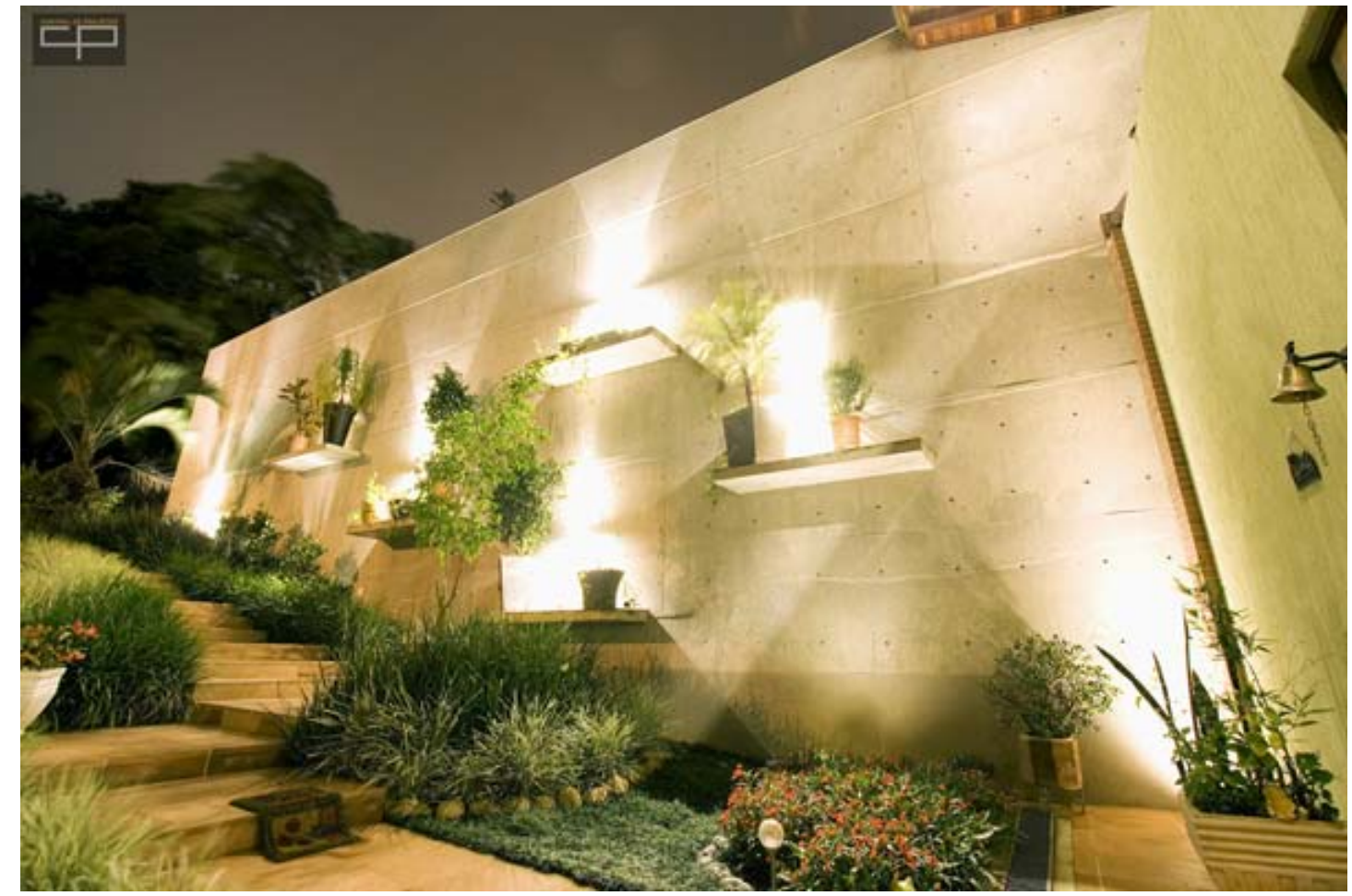

Figura 92 - Residência Nunes: detalhe entrada

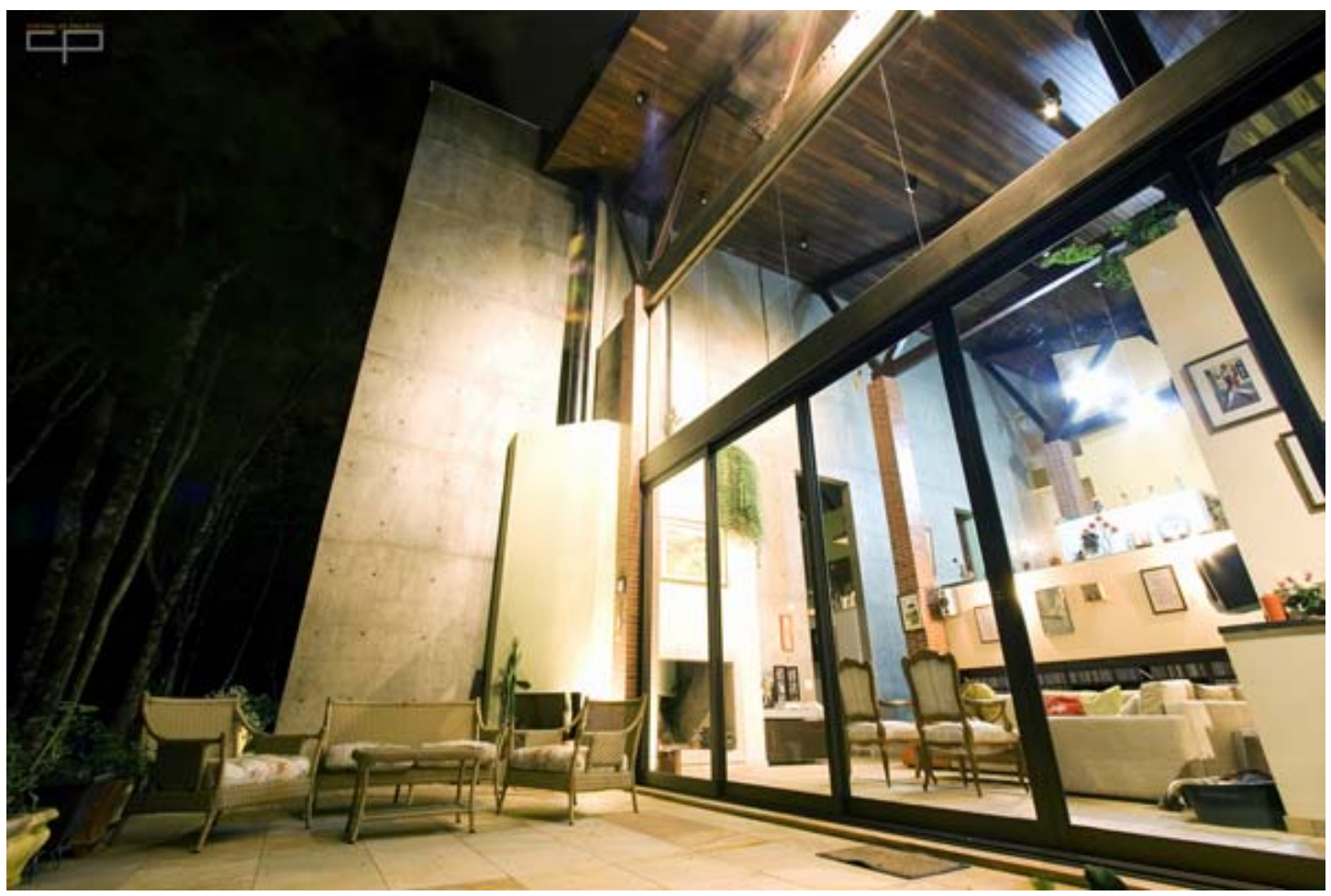

Figura 93 - Residência Nunes: perspectiva lateral 


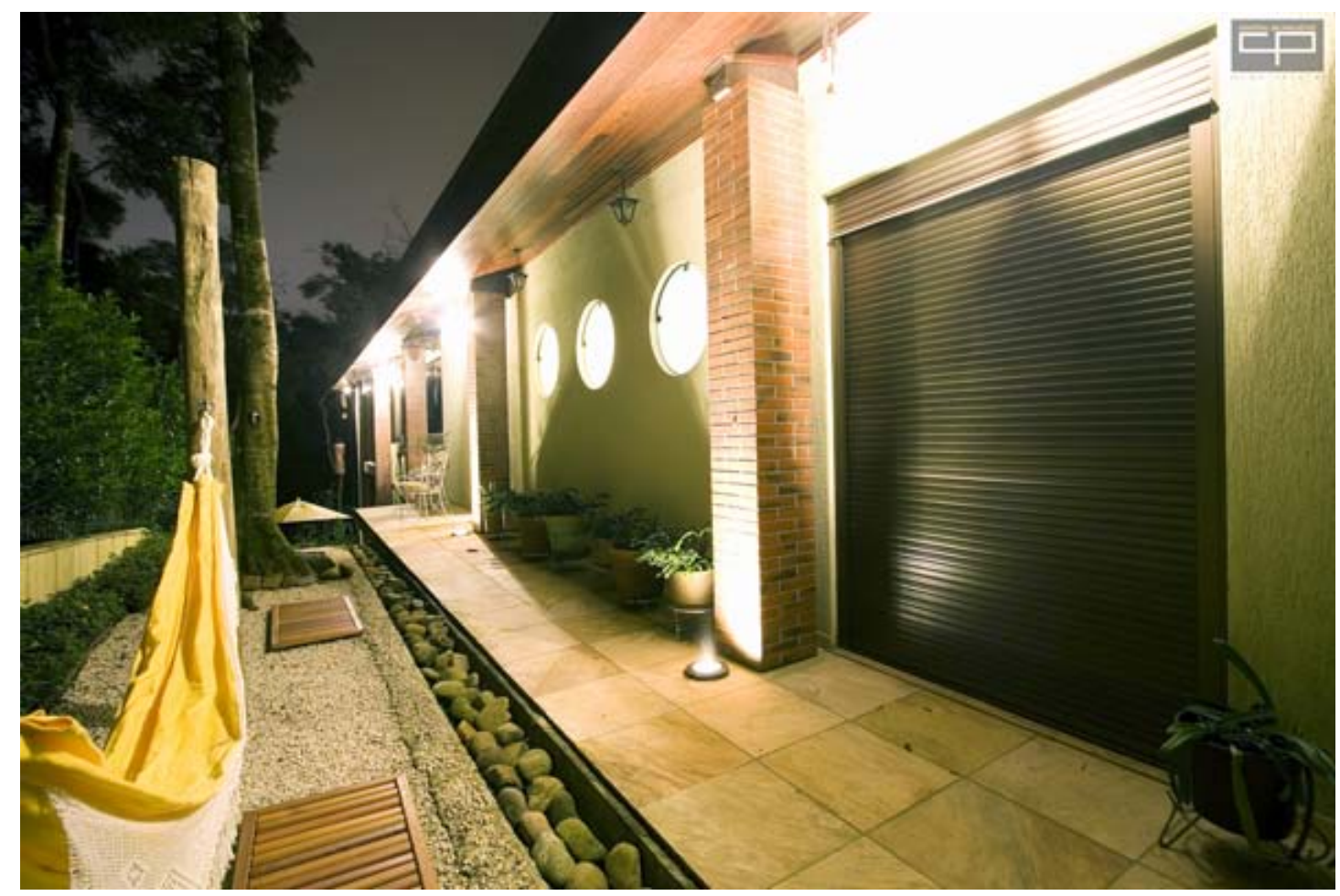

Figura 94 - Residência Nunes: facha lateral

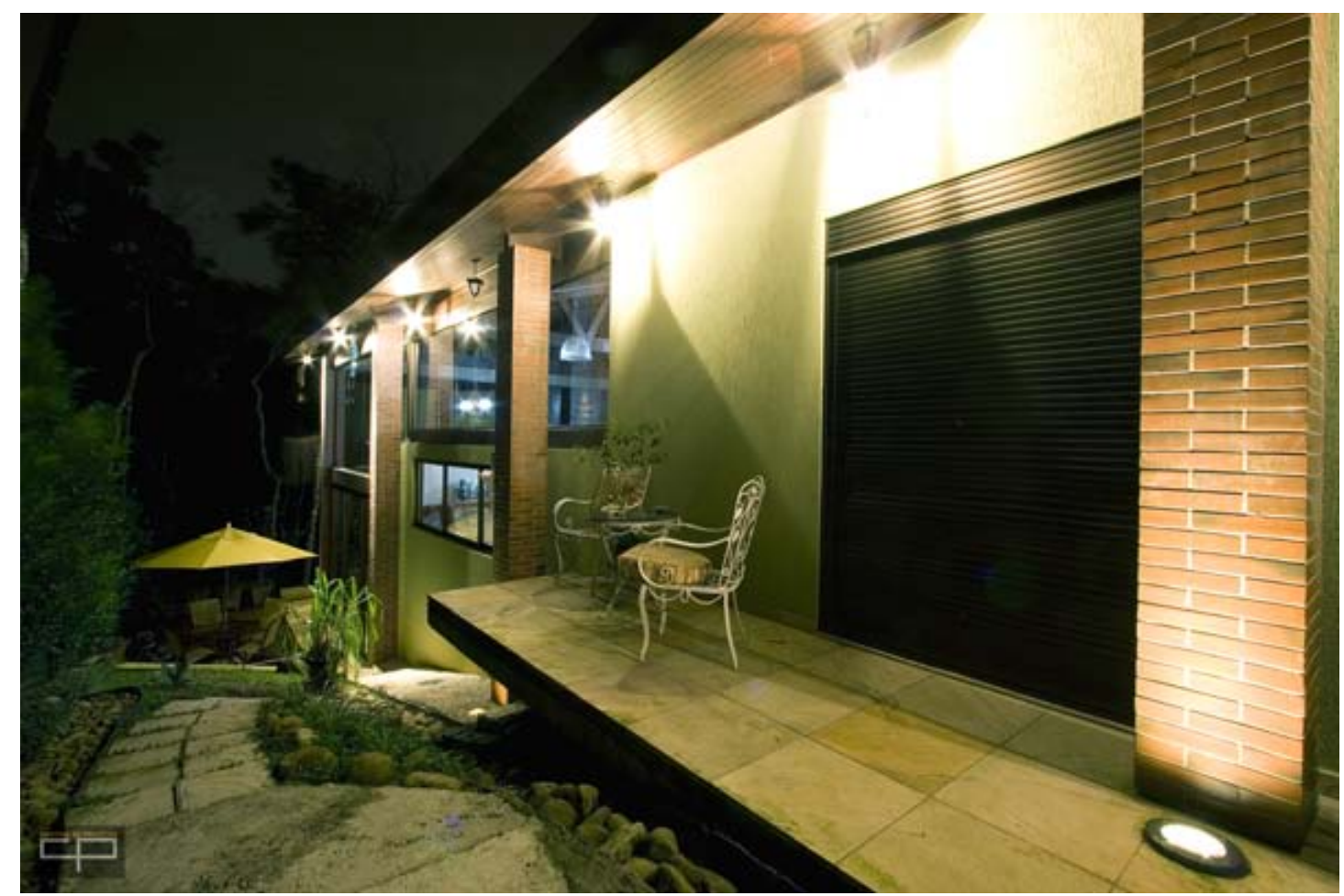

Figura 95 - Residência Nunes: varanda quartos 


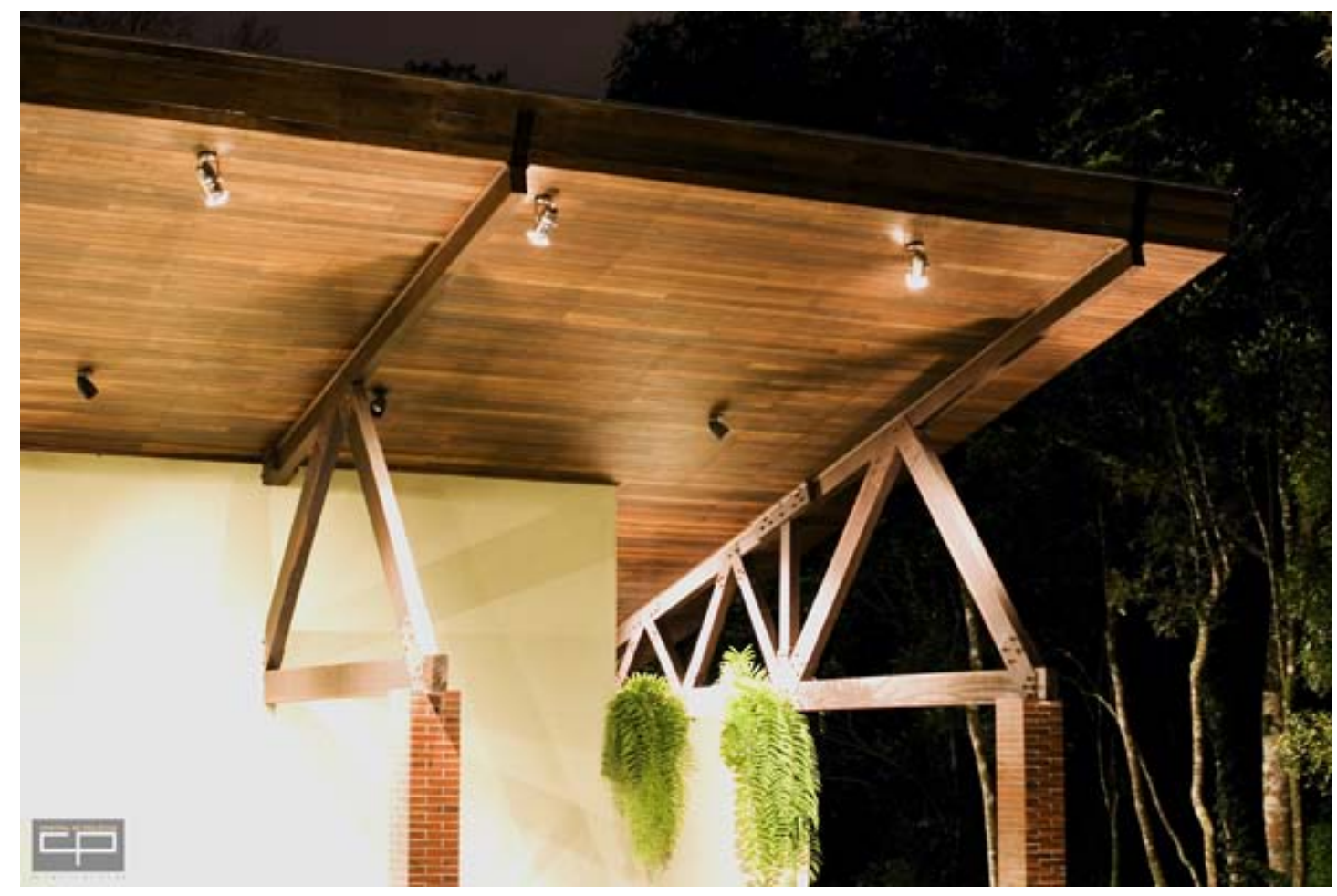

Figura 96 - Residência Nunes: detalhe cobertura

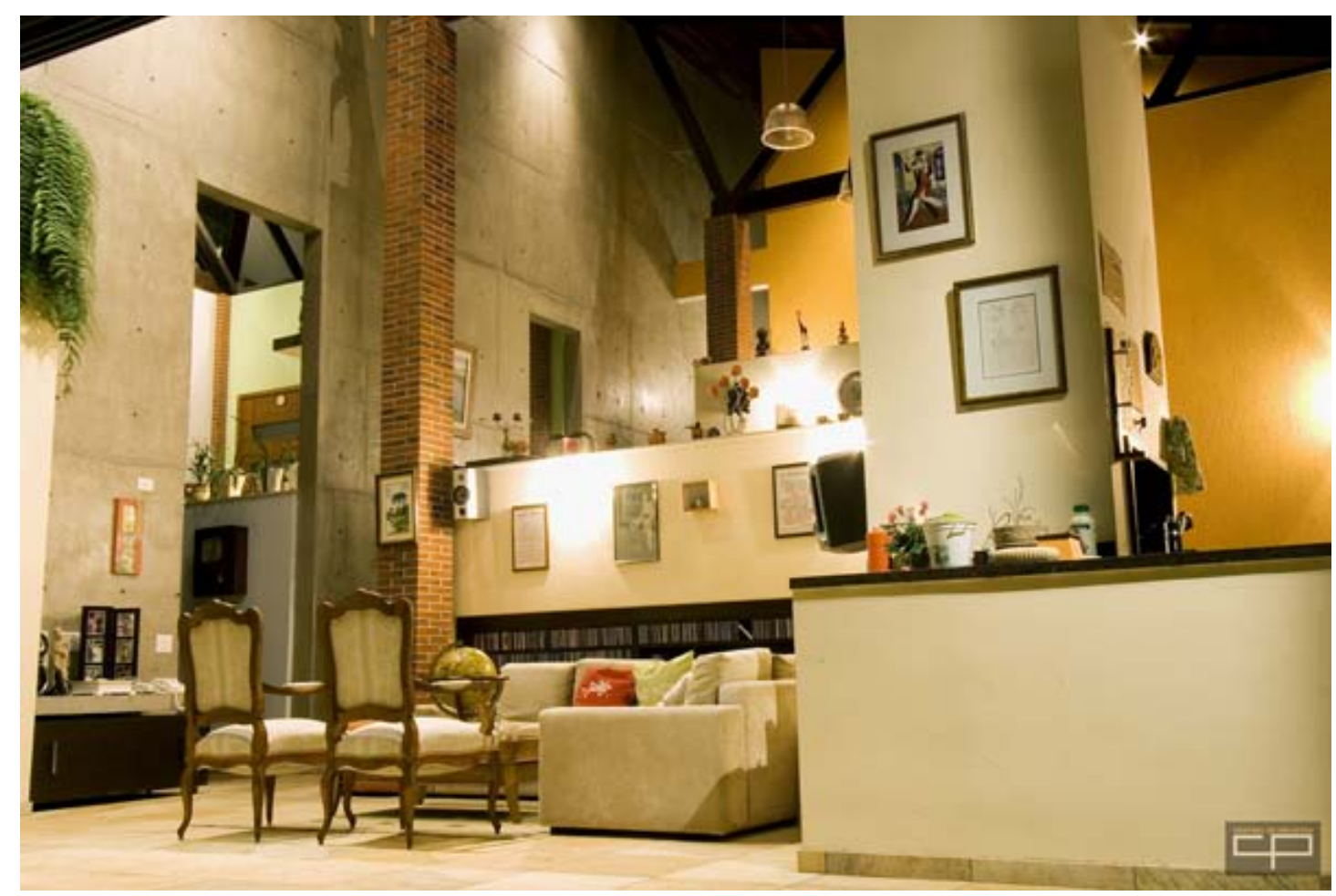

Figura 97 - Residência Nunes: estar 


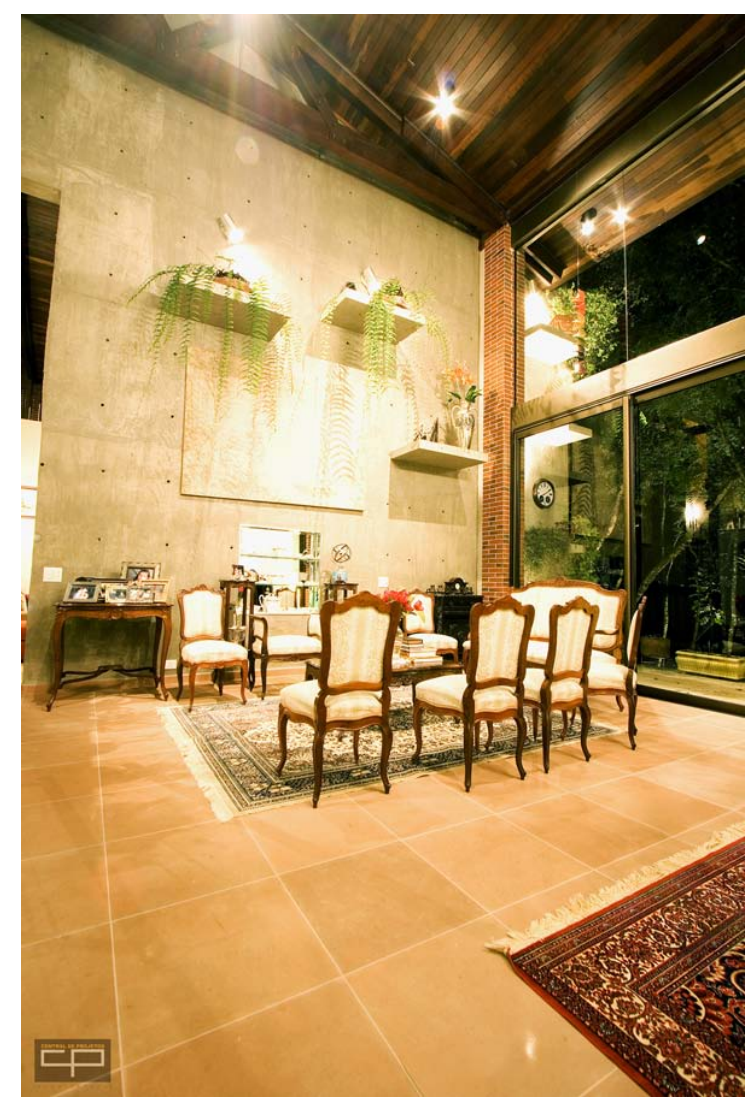

Figura 98 - Residência Nunes: jantar

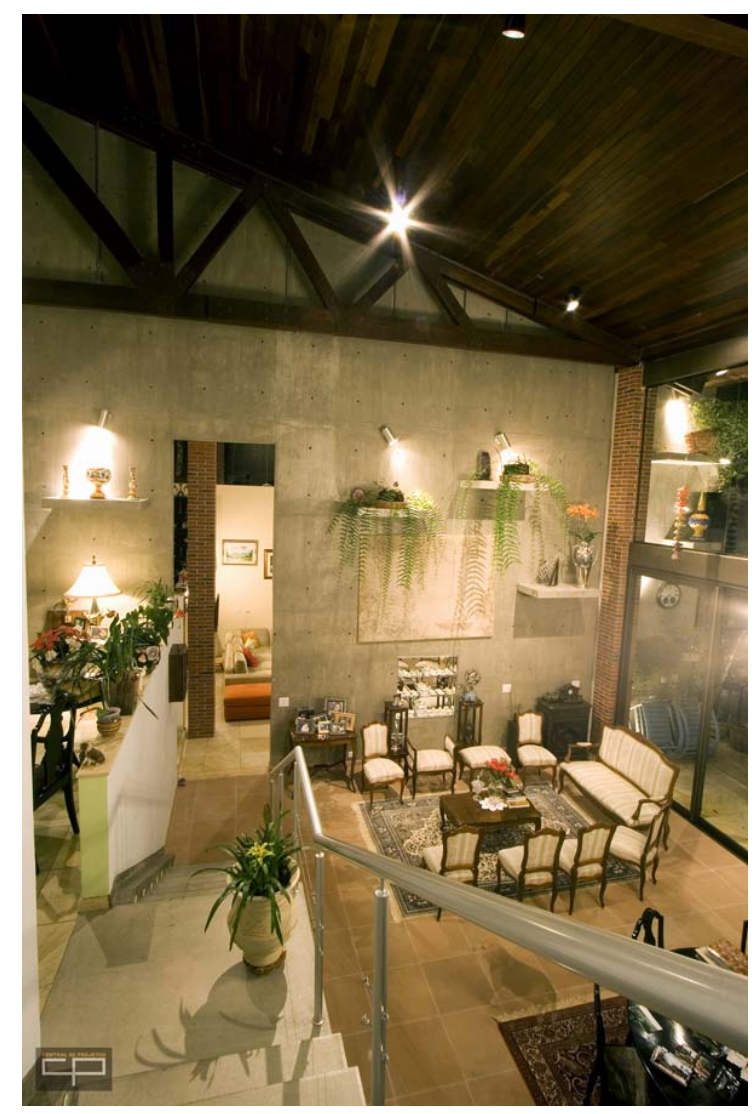

Figura 99 - Residência Nunes: interior 


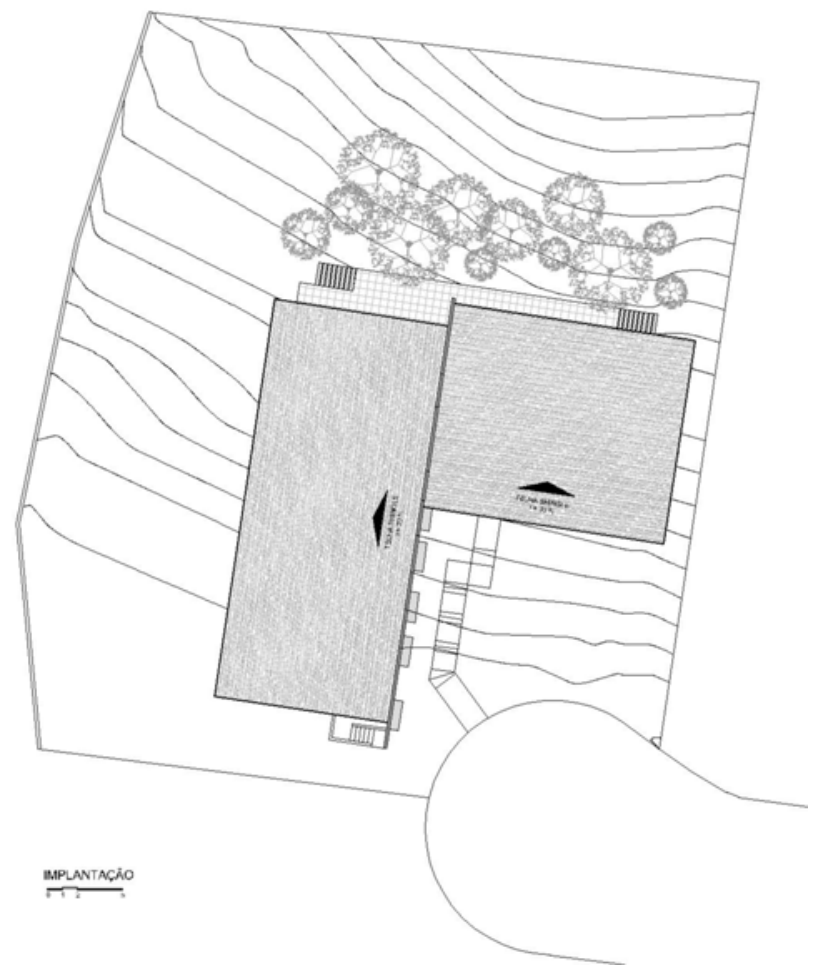

Figura 100 - Residência Nunes: implantação

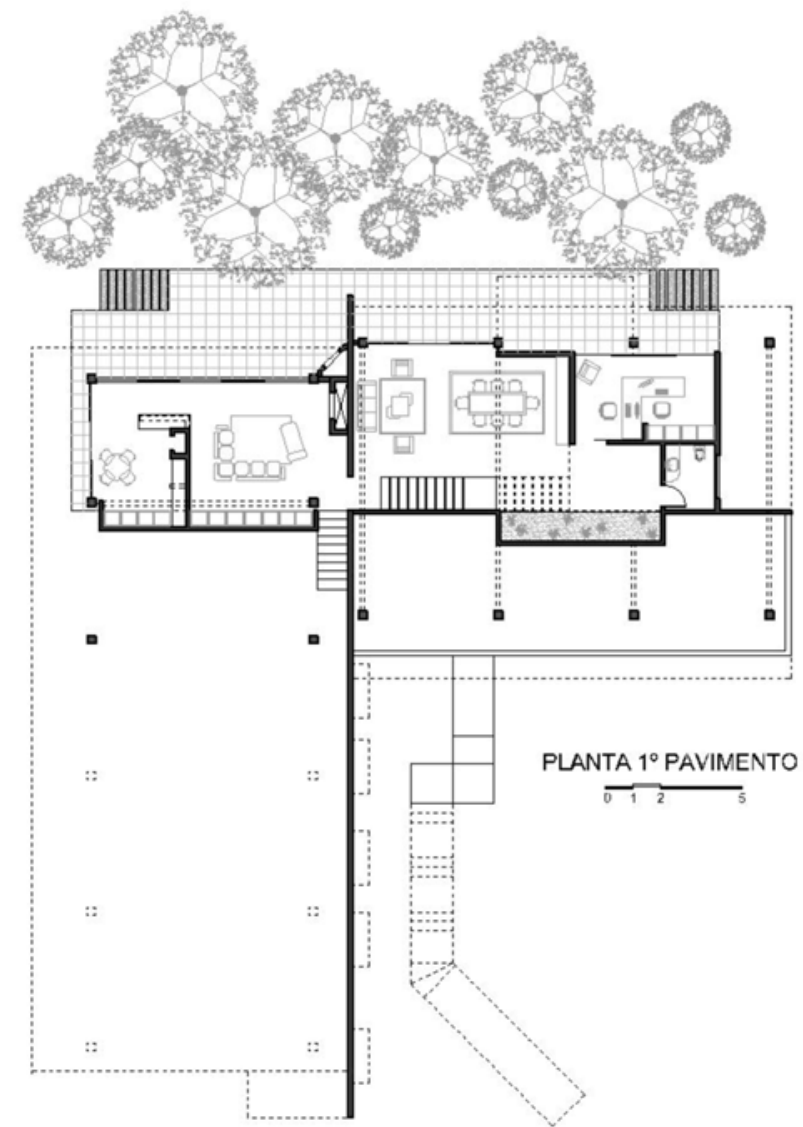


Figura 101 - Residência Nunes: planta primeiro pavimento

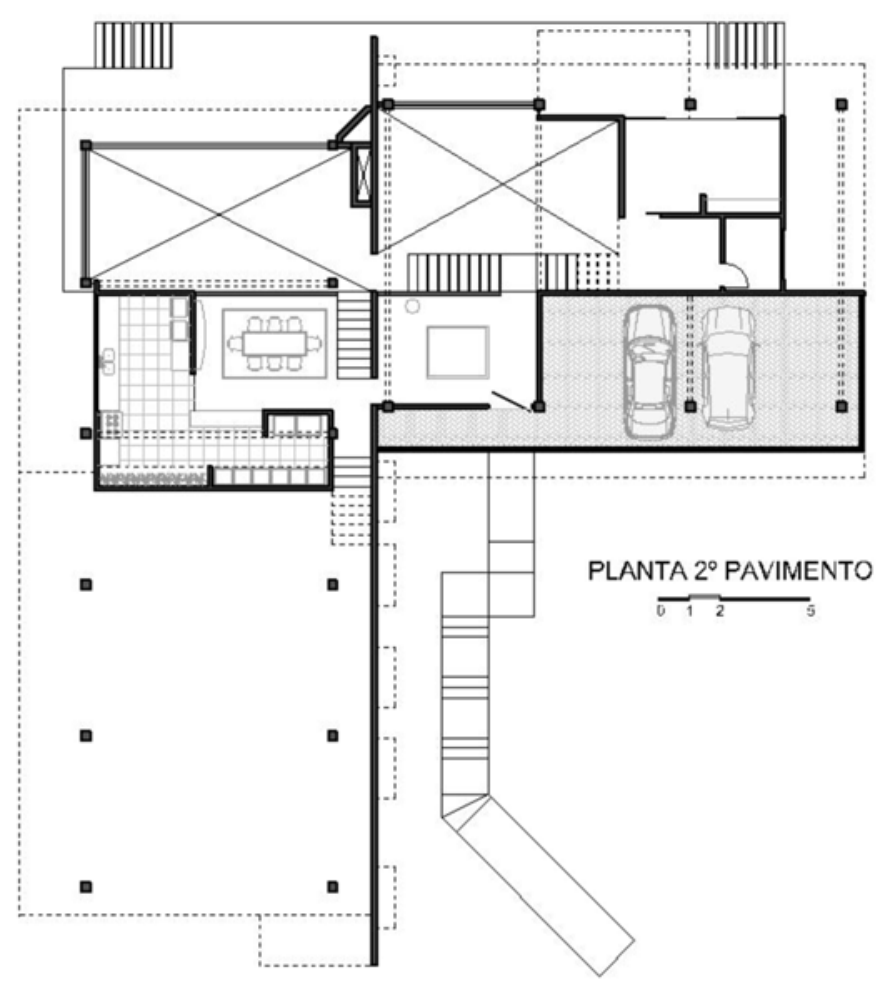

Figura 102 - Residência Nunes: planta segundo pavimento

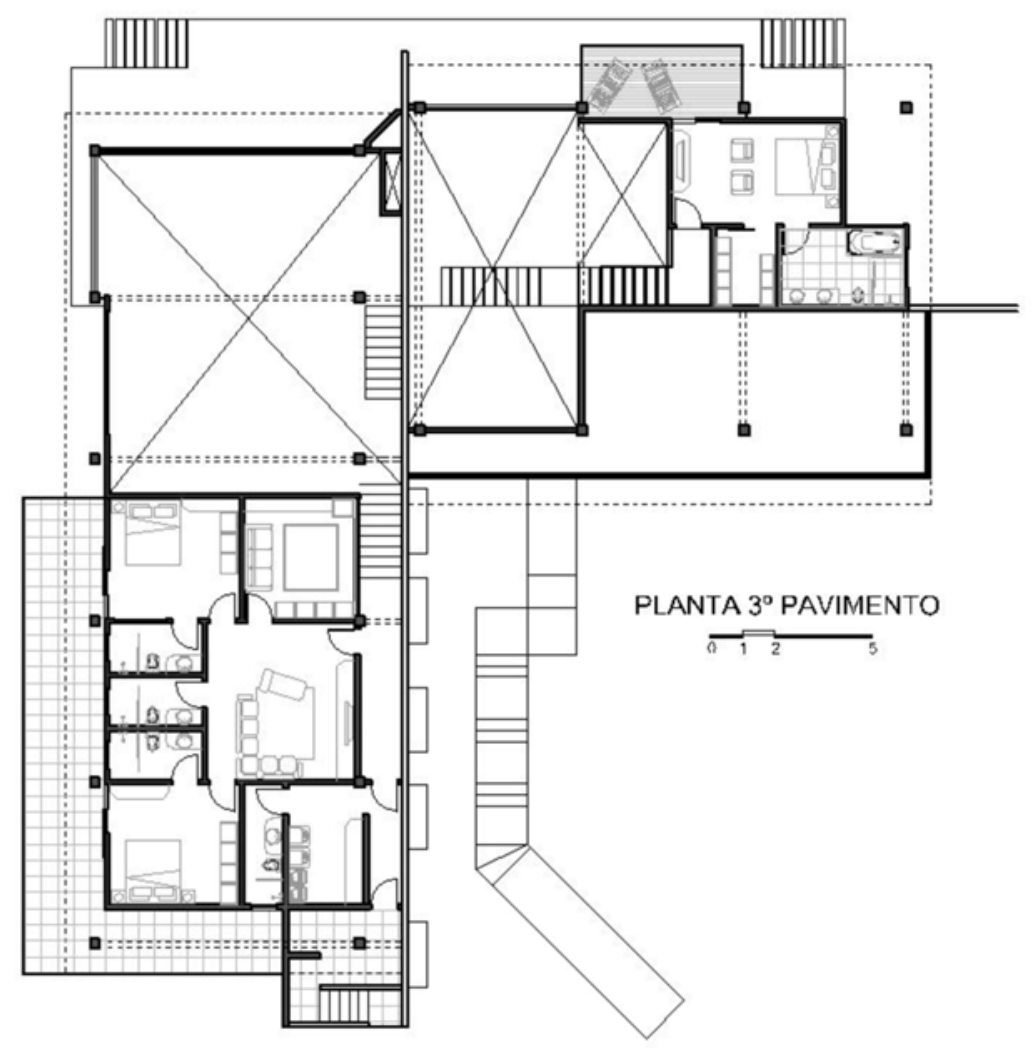

Figura 103 - Residência Nunes: planta terceiro pavimento 


\subsection{Visão geral}

Finalizada em 2006, a residência projetada pela Central de Projetos tira partido do desnível do lote para a concepção da obra. A casa acomoda-se no terreno, em três níveis diferentes, buscando adaptar-se ao declive existente.

O acesso de veículos e pedestres acontece pelo pavimento intermediário, onde estão localizadas cozinha e copa. Meio nível abaixo, encontram-se as áreas de estar, jantar, churrasqueira e escritório. Todos estes ambientes se abrem para o bosque existente nos fundos do terreno, através de grandes portas-janelas envidraçadas.

Meio nível acima do acesso principal, estão distribuídos os dormitórios e home theater. A suíte principal, voltada para o norte, é acessada por uma escada independente, garantindo a privacidade do ambiente. As suítes menores tem orientação noroeste, e compartilham um terraço.

A parede em blocos de concreto que se estende longitudinalmente no terreno é marcante na volumetria do projeto. O pé direito alto e os grandes planos envidraçados contrastam com a estrutura de madeira da cobertura.

Os projetos de paisagismo e luminotecnia valorizam o projeto arquitetônico, dando ainda maior destaque à parede de concreto, na área de acesso do edifício.

\subsection{Implantação e relação com o entorno}

A residência procura se adaptar ao máximo as características topográficas do sítio. Os pavimentos são organizados em meios níveis, se acomodando ao perfil original do terreno.

Garagem, cozinha e copa ficam no pavimento intermediário, voltadas para o sul. As áreas sociais - estar, jantar, churrasqueira - foram posicionadas na cota mais baixa do terreno, voltadas para o fundo do lote, com orientação norte vista para o bosque existente. A suíte do casal, no último pavimento, possui a mesma orientação e visuais das áreas sociais. A insolação excessiva nos dias de verão é amenizada pela varanda coberta anexa ao quarto. Os outros quartos tem orientação leste e se abrem através de portas-janela para o jardim lateral da casa. 
Além de tirar partido da topografia e distribuir os ambientes de forma a aproveitar as visuais do terreno, a casa se integra ao entorno através de uma implantação organicista. A cobertura, em estrutura de madeira e telhas de barro, possui inclinação similar ao perfil original. $O$ forro em madeira tratada apenas com verniz nos beirais e nos ambientes internos traz sensação de calor e conforto à obra.

\subsection{Programa de atividades}

Construída para um casal com dois filhos, um dos pontos essenciais do projeto é a privacidade da suíte principal. Possui um acesso exclusivo, feito através de uma escada independente dos outros quartos. Apesar de estar na mesma cota das outras suítes, não possui qualquer ligação com estas, ficando completamente a parte e desfrutando de total privacidade.

Os outros quartos possuem um estar íntimo próprio, e uma sala de TV anexa. Todo o percurso entre estas suítes e a as áreas de serviço da casa pode ser feito sem passar pela área social.

A área social da casa é marcada pela continuidade espacial. A divisão entre ambientes é feita através dos desníveis e mobiliário. Anexa as salas de estar e janta, existe um banheiro de uso social. O escritório se encontra na mesma cota, mas caracteriza-se como uma área privada, sendo o único ambiente fechado - além do banheiro - neste pavimento.

\subsection{Partido arquitetônico}

O partido decorre do aproveitamento do perfil original do terreno e da busca pela privacidade das áreas íntimas da casa em relação à extensa área social. As decisões de projeto deixam transparecer uma atitude contextualista nesta arquitetura, trazendo para a residência as cores e materiais do entorno e colocando as necessidades do usuário como foco do processo de criação. Quartos e salas de estar foram posicionados de maneira que pudesse usufruir dos serviços da casa passar pela área social. Os trajetos e privacidade dos proprietários - inclusive em relação aos outros quartos - foram determinantes no projeto desta residência. 
Diferente da maioria das casas analisadas até aqui, esta residência demonstra a intenção de integrar-se ao meio de forma orgânica, não somente pela implantação, mas também pelo uso de materiais com características "quentes" pedra, madeira, tijolo. Outra diferença entre esta e as outras residências do trabalho é a presença do telhado aparente: das oito residências escolhidas, apensa três possuem esta característica - e uma delas é uma reciclagem, sendo o telhado aparente parte da construção original que foi preservada, como veremos a seguir.

Esteticamente, a volumetria da casa evidencia a contemporaneidade do projeto, especialmente nas grandes áreas envidraçadas que se abrem para os jardins. O projeto de luminotecnia realça os contornos e materiais da edificação trazendo dramaticidade à obra.

\subsection{Sistema construtivo}

O sistema construtivo do projeto é composto pela estrutura de madeira do telhado apoiada sobre pilares de concreto, revestidos com tijolo aparente. As tesouras que sustentam a cobertura ficam aparentes no interior da residência.

A parede em blocos de concreto que se estende longitudinalmente em relação ao terreno é autoportante e quebra a continuidade da modulação dos pilares. Todos os pilares são aparentes, ficando clara a distinção entre apoios e fechamentos da residência.

As esquadrias de alumínio, com acabamento em tom escuro, suportam grande planos de vidro que possibilitam o diálogo do interior com o entorno da residência. A maior parte dos cômodos se abre para a área externa - seja para área lateral ou para o bosque nos fundos do terreno - e fazem dos jardins uma extensão do ambiente, através de espaços de transição entre interior/exterior como varandas e terraços.

\subsection{Intenção Plástica}

O arquiteto procura explorar as qualidades plásticas da estrutura e materiais de revestimento aparentes, valorizados pelo projeto de luminotecnia. Os materiais 
utilizados na residência - madeira, concreto, tijolo - são tratados apenas com verniz, mantendo suas características originais. Estes materiais contrastam com a escolha do mobiliário, que vai do contemporâneo ao rebuscado. Entretanto, essa relação é harmônica e faz da casa um ambiente convidativo, distanciando-se da característica asséptica e pouco pessoal frequentemente observada em projetos que buscam uma estética contemporânea.

O plano de concreto marca o acesso da residência e é pontuado por floreiras suspensas que trazem ritmo ao passeio. Assim como o projeto de luminotecnia, o projeto de paisagismo é tratado como parte essencial e indissociável desta arquitetura.

Esse projeto possui características pouco observadas em outros exemplos da cidade. Em primeiro lugar, a casa possui a estética contemporânea sem perder a aparência residencial que muitas vezes é esperada pelo proprietário, principalmente devido opção do arquiteto em manter a inclinação da cobertura aparente. Em um segundo momento, a planta aberta e continuidade espacial não comprometem a privacidade dos ambientes da residência, devido à boa utilização dos meios níveis e distribuição dos espaços. 
12. GUSTAVO PINTO: RECICLAGEM ANTIGO MOINHO

Chácara em Almirante Tamandaré

Almirante Tamandaré, Região Metropolitana de Curitiba, Paraná

Arquitetos: Gustavo Pinto

Conclusão: 2009

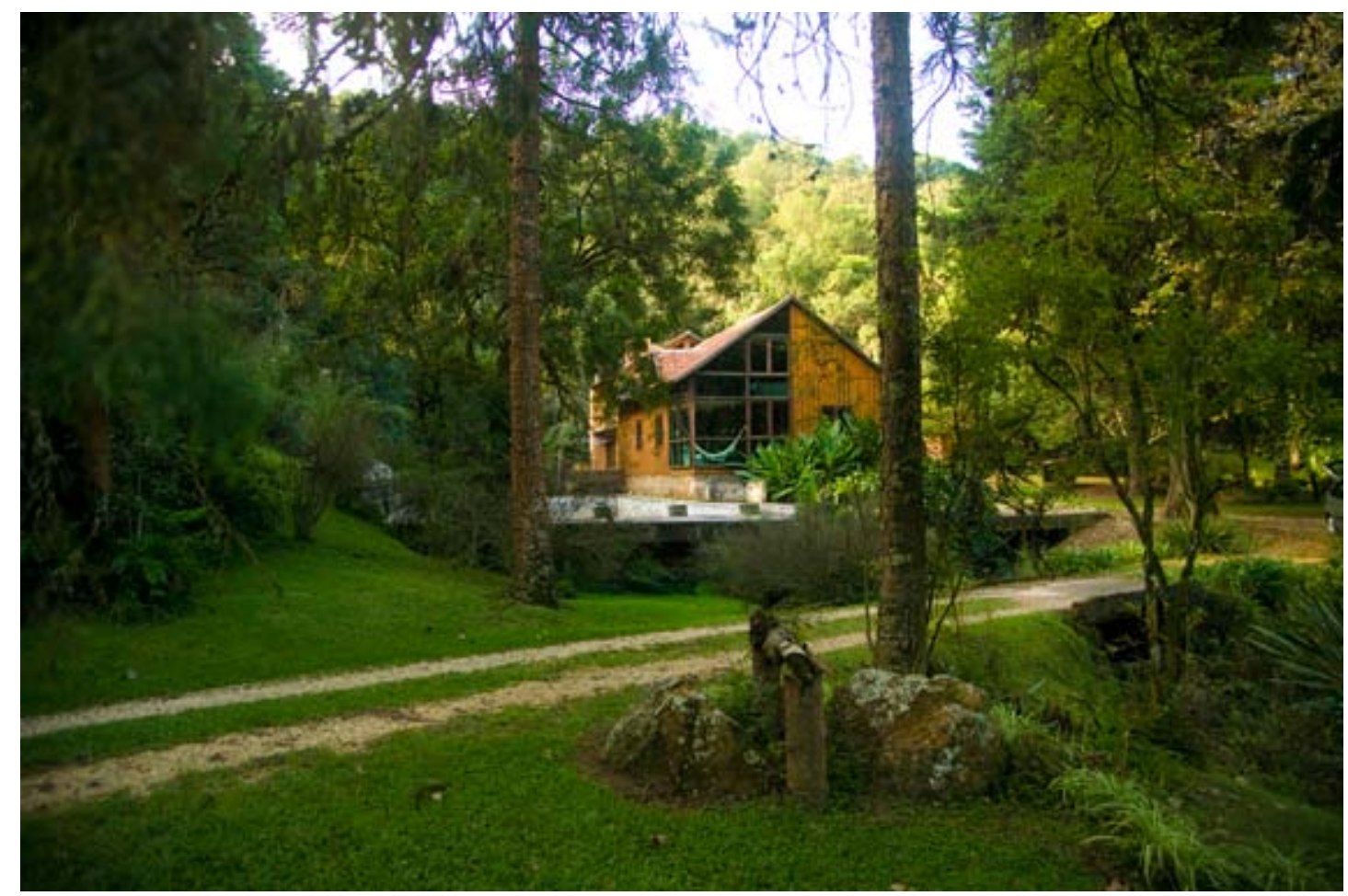

Figura 104 - Casa Almirante Tamandaré: entorno 


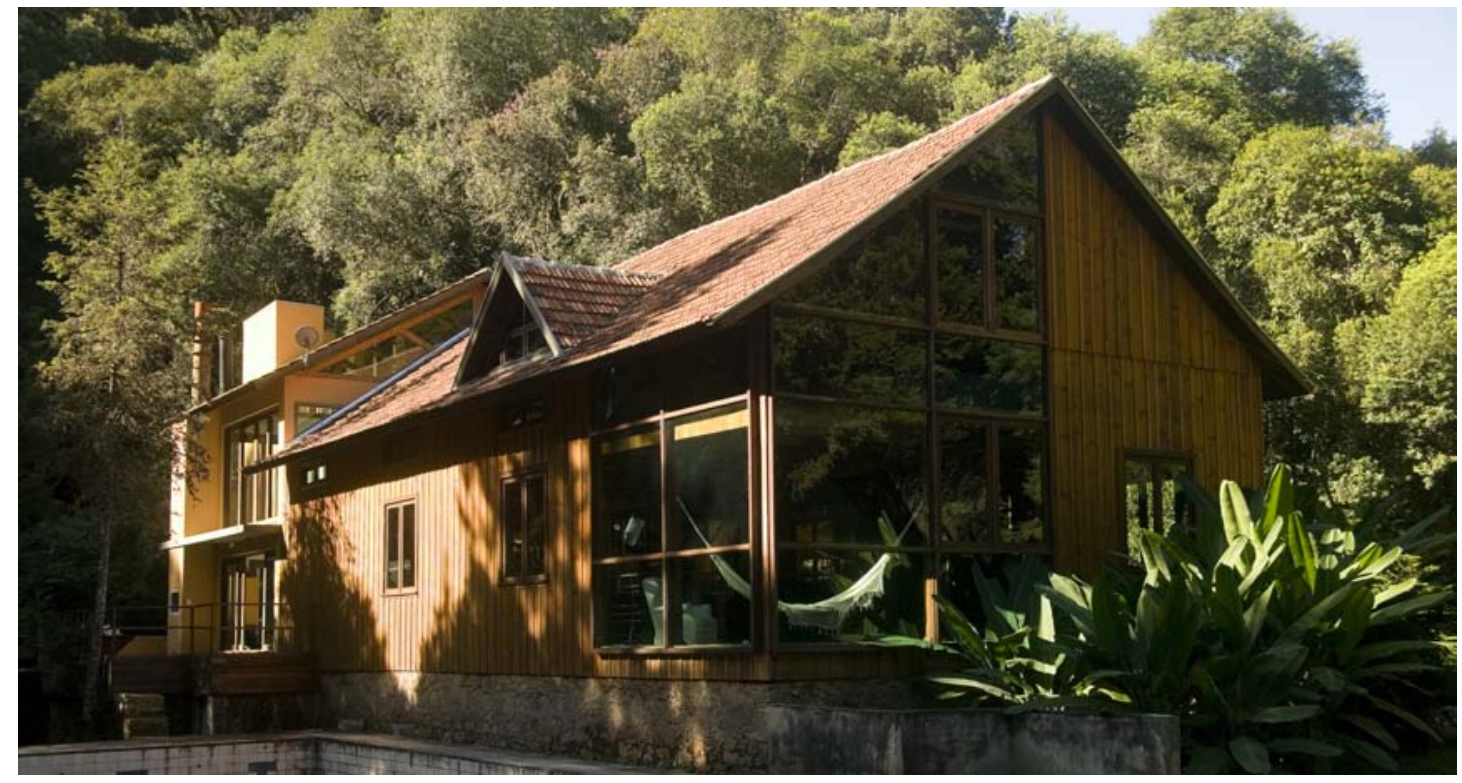

Figura 105 - Casa Almirante Tamandaré: perspectiva externa

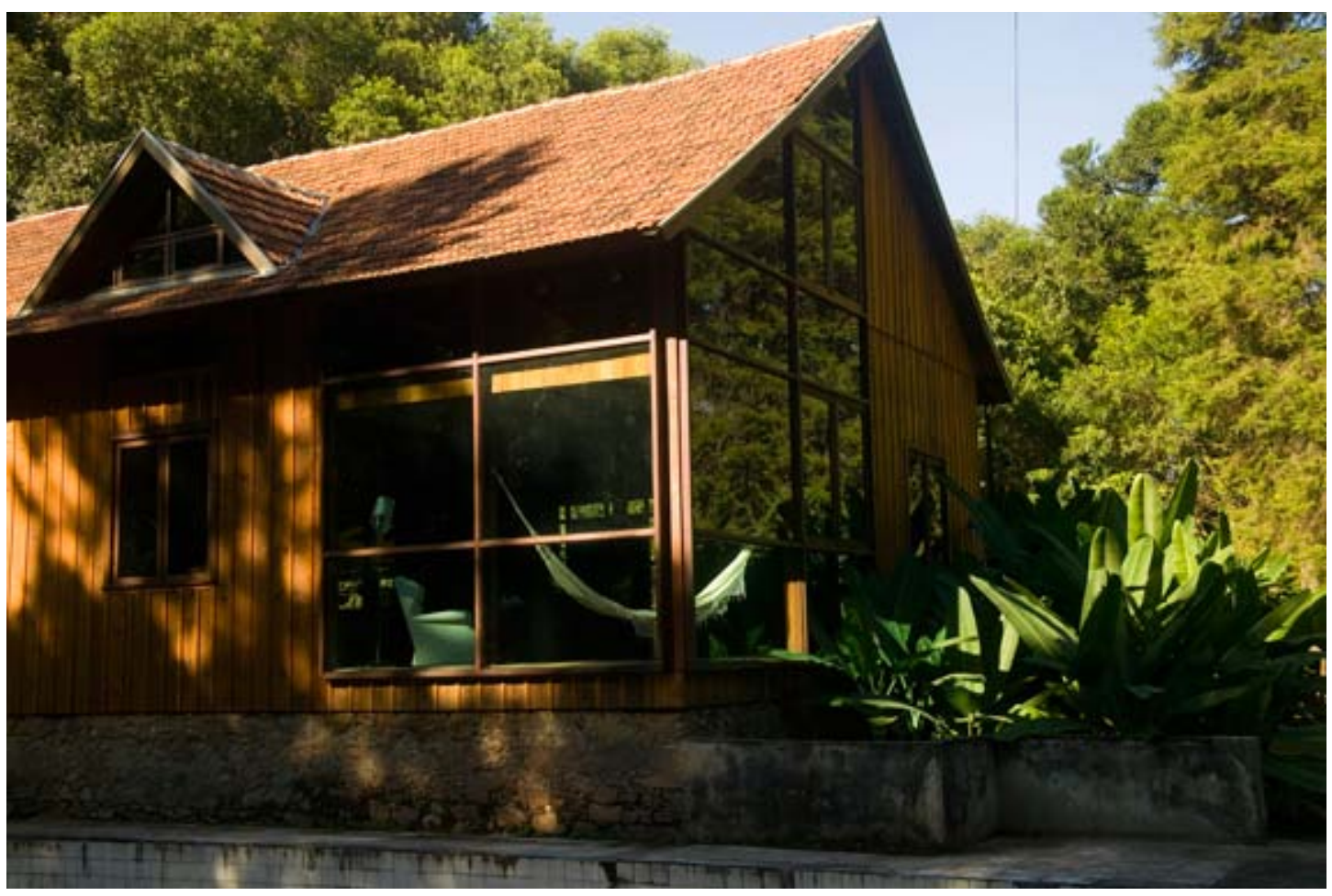

Figura 106 - Casa Almirante Tamandaré: construção existente 


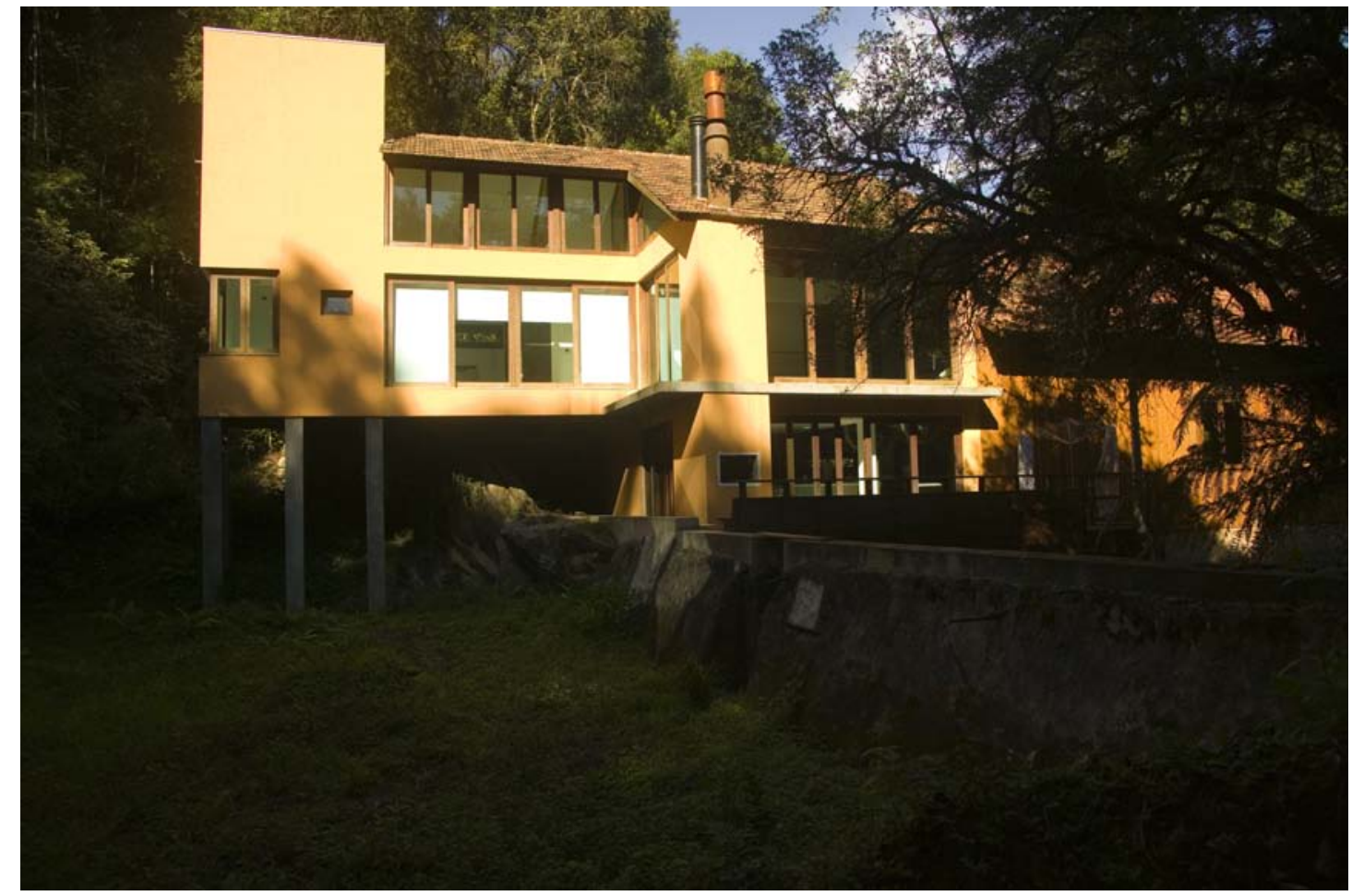

Figura 107 - Casa Almirante Tamandaré: construção anexa

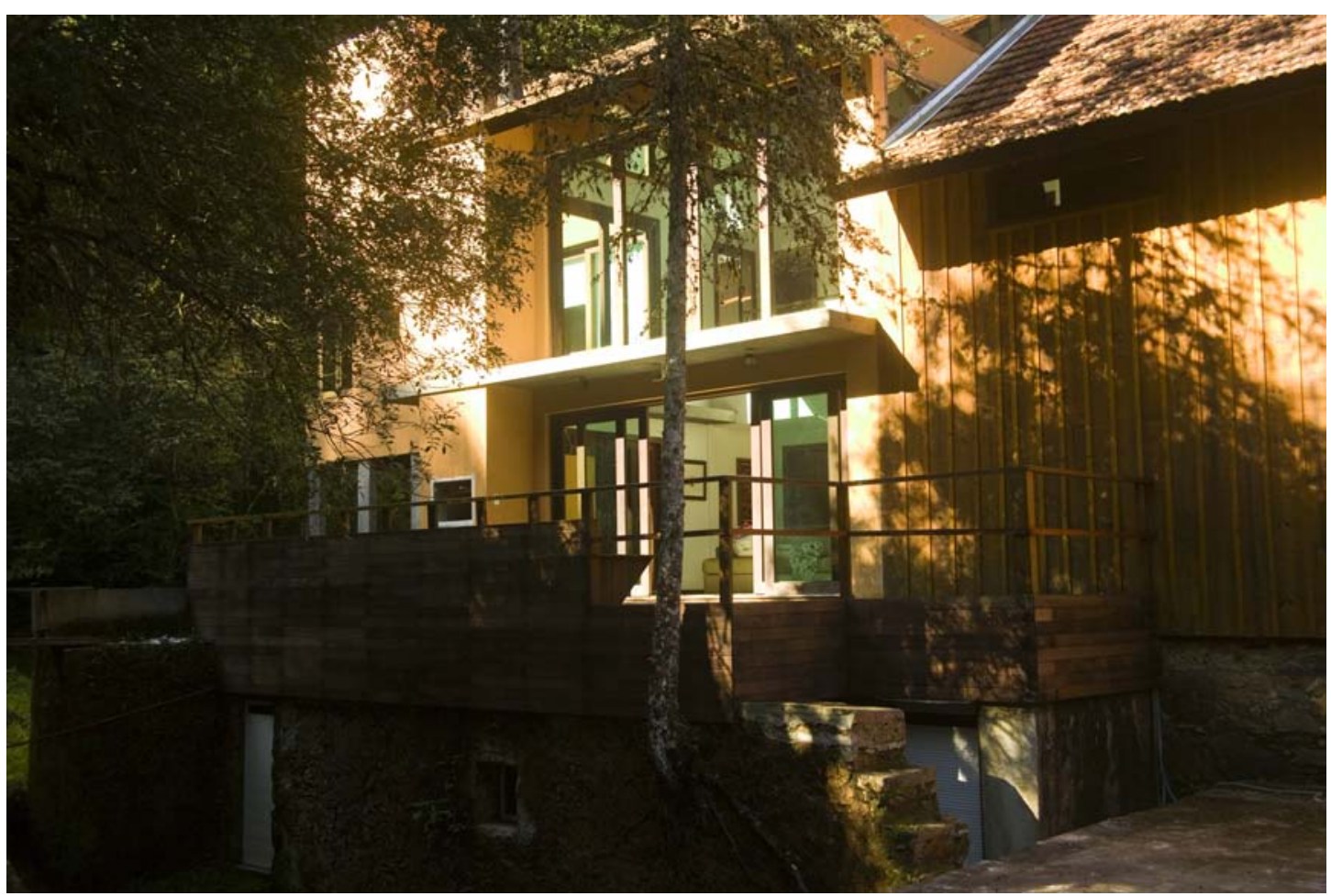

Figura 108 - Casa Almirante Tamandaré: vista lateral 


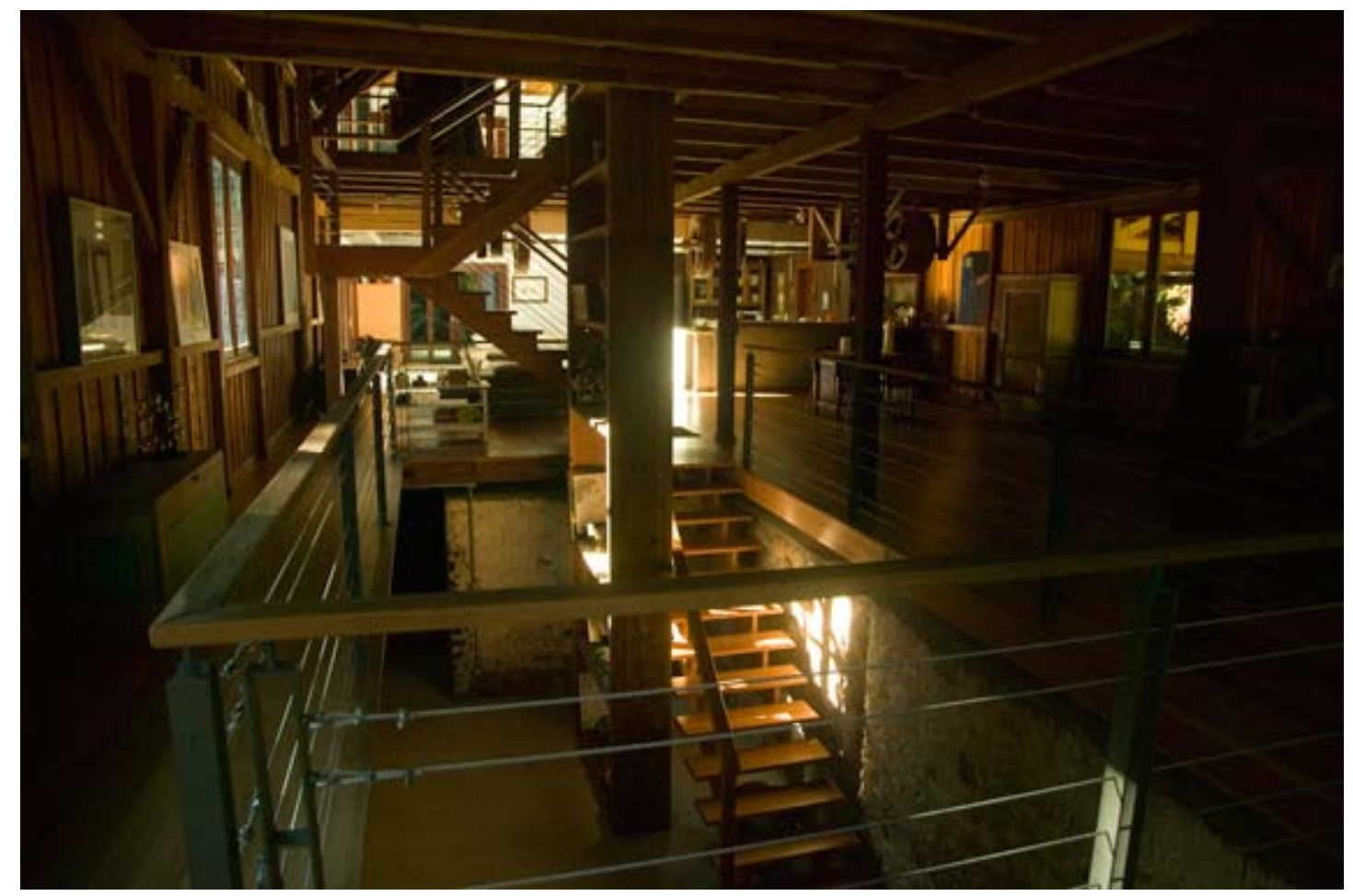

Figura 109 - Casa Almirante Tamandaré: interior

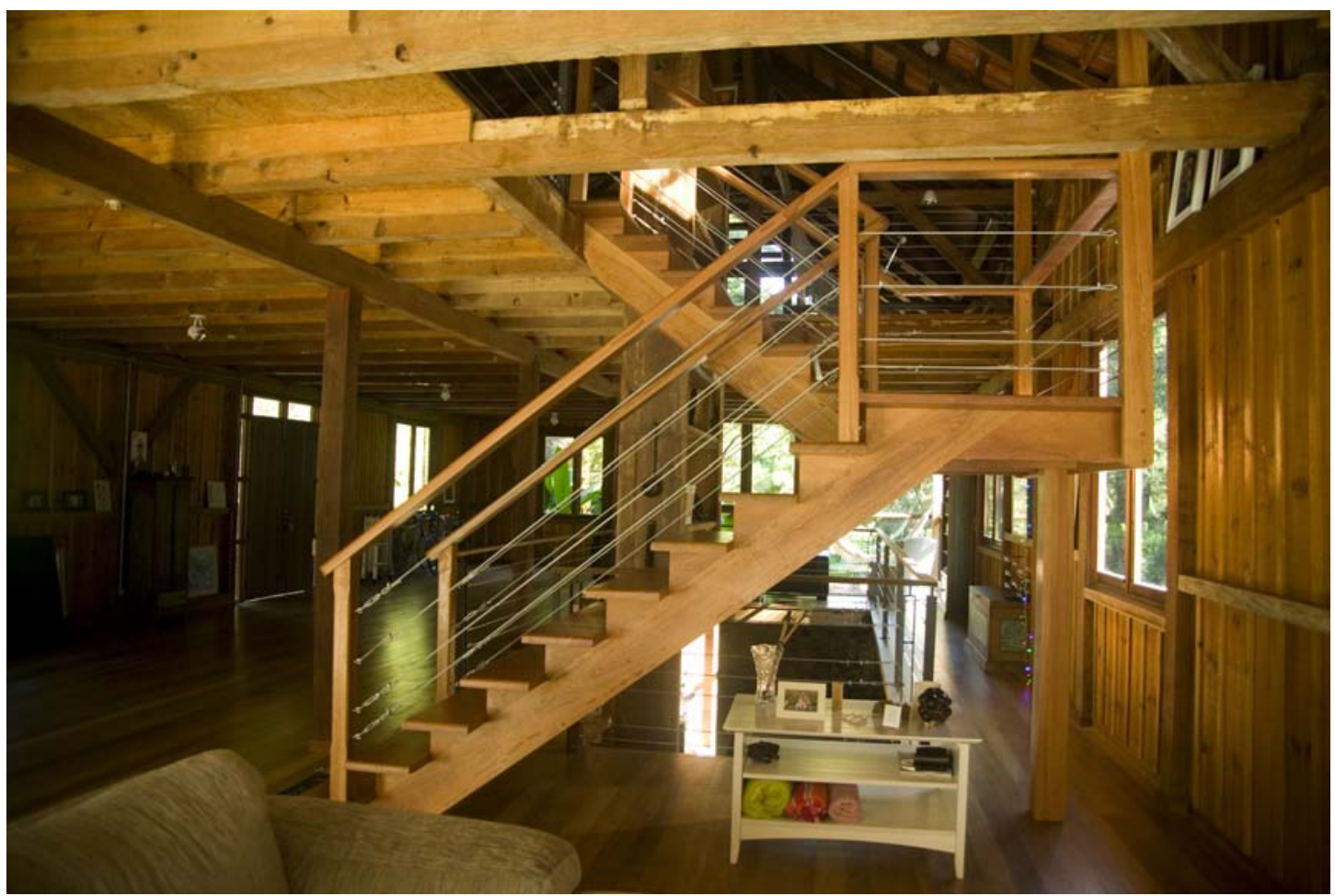

Figura 110 - Casa Almirante Tamandaré: detalhe escada 


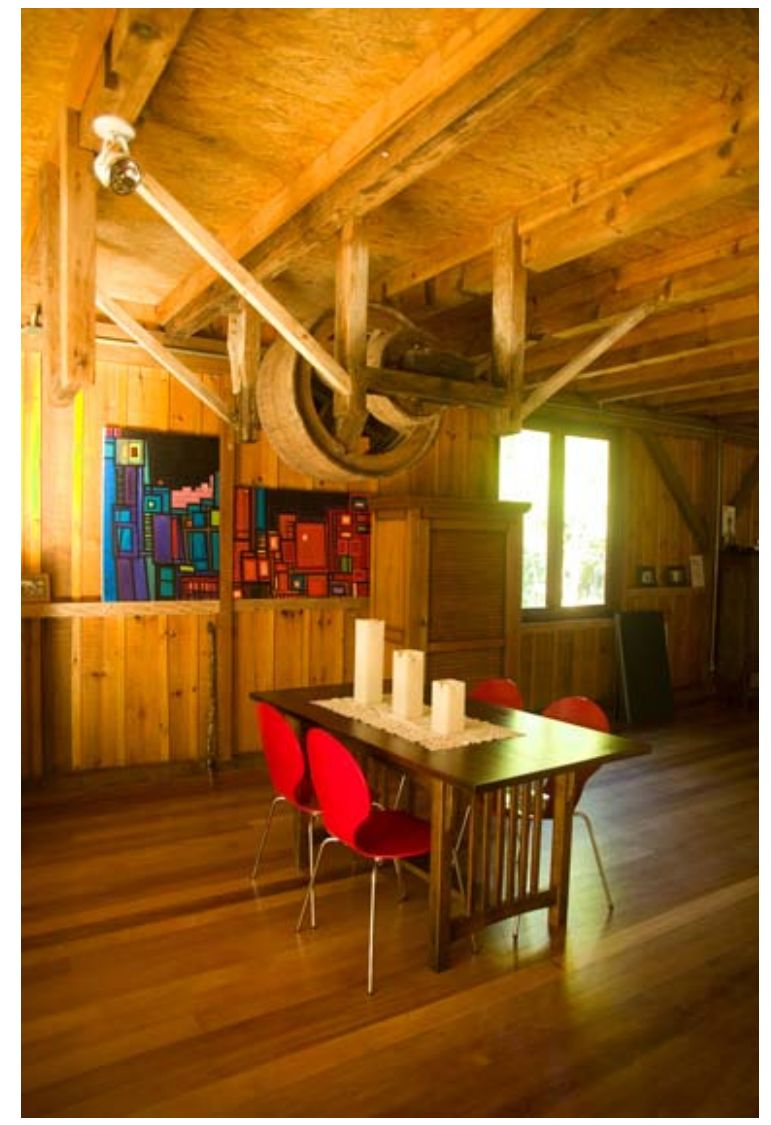

Figura 111 - Casa Almirante Tamandaré: engrenagem original

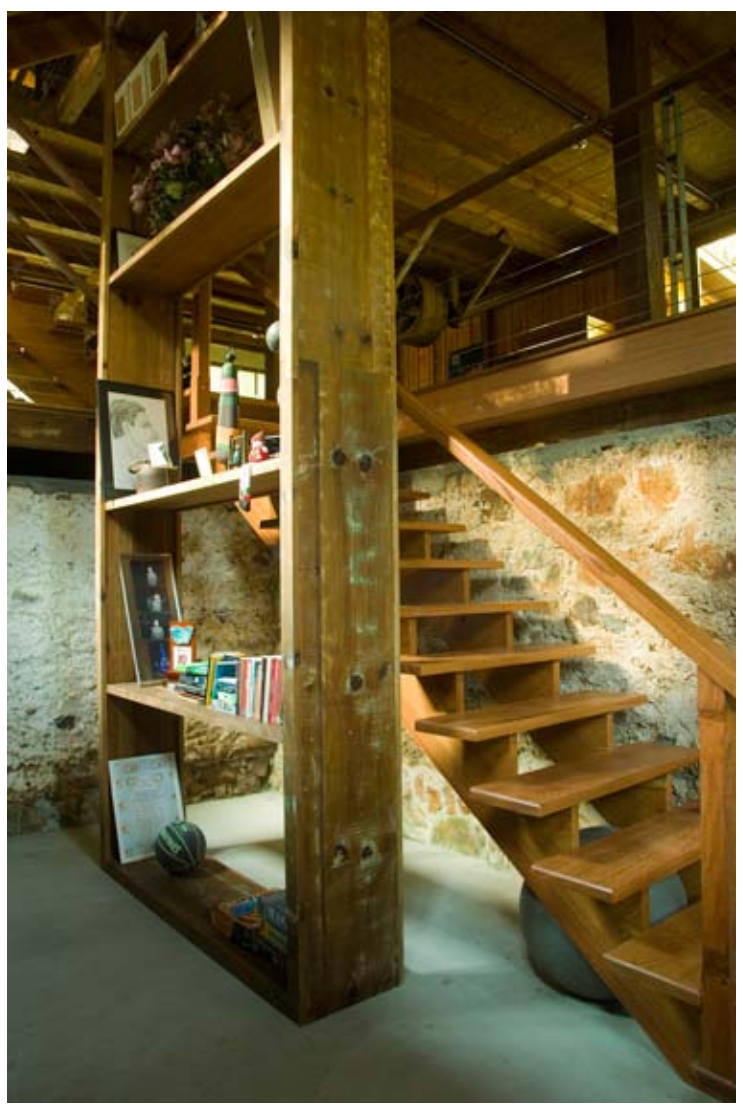

Figura 112 - Casa Almirante Tamandaré: detalhe escada 


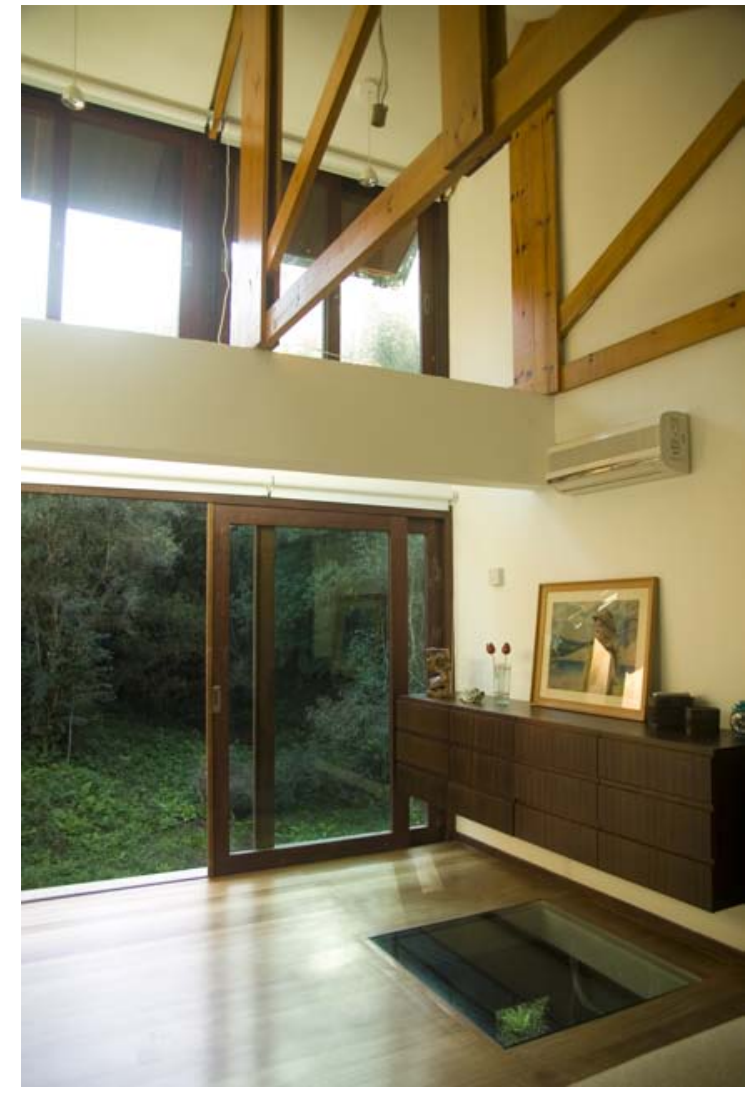

Figura 113 - Casa Almirante Tamandaré: tesouras aparentes

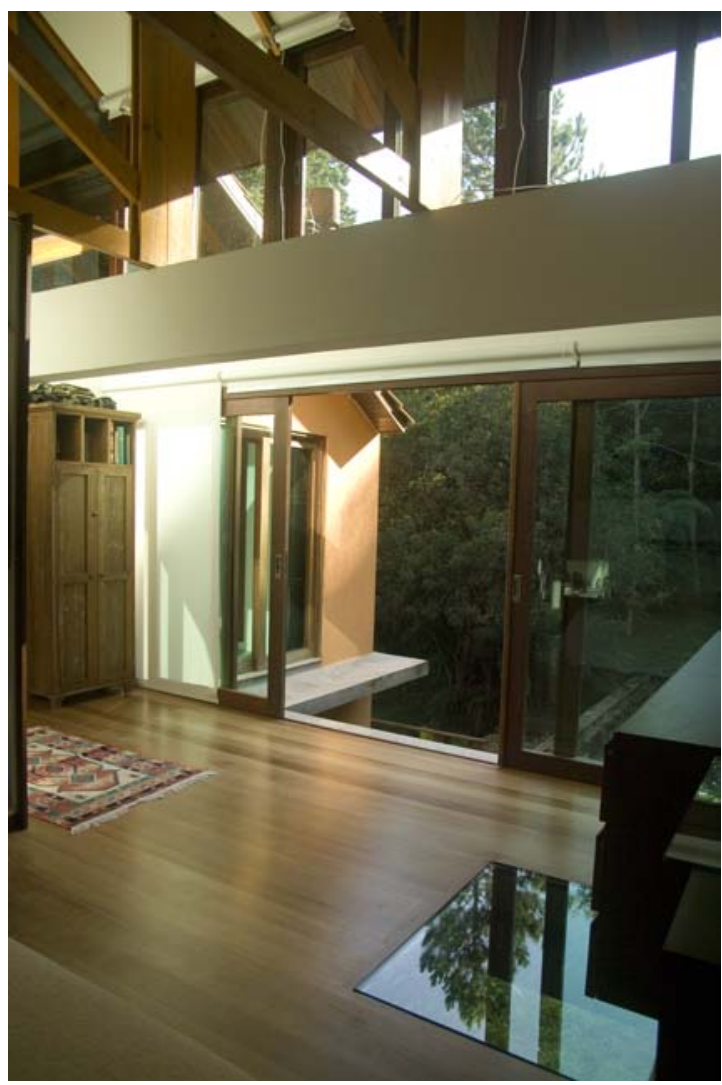

Figura 114 - Casa Almirante Tamandaré: piso envidraçado 


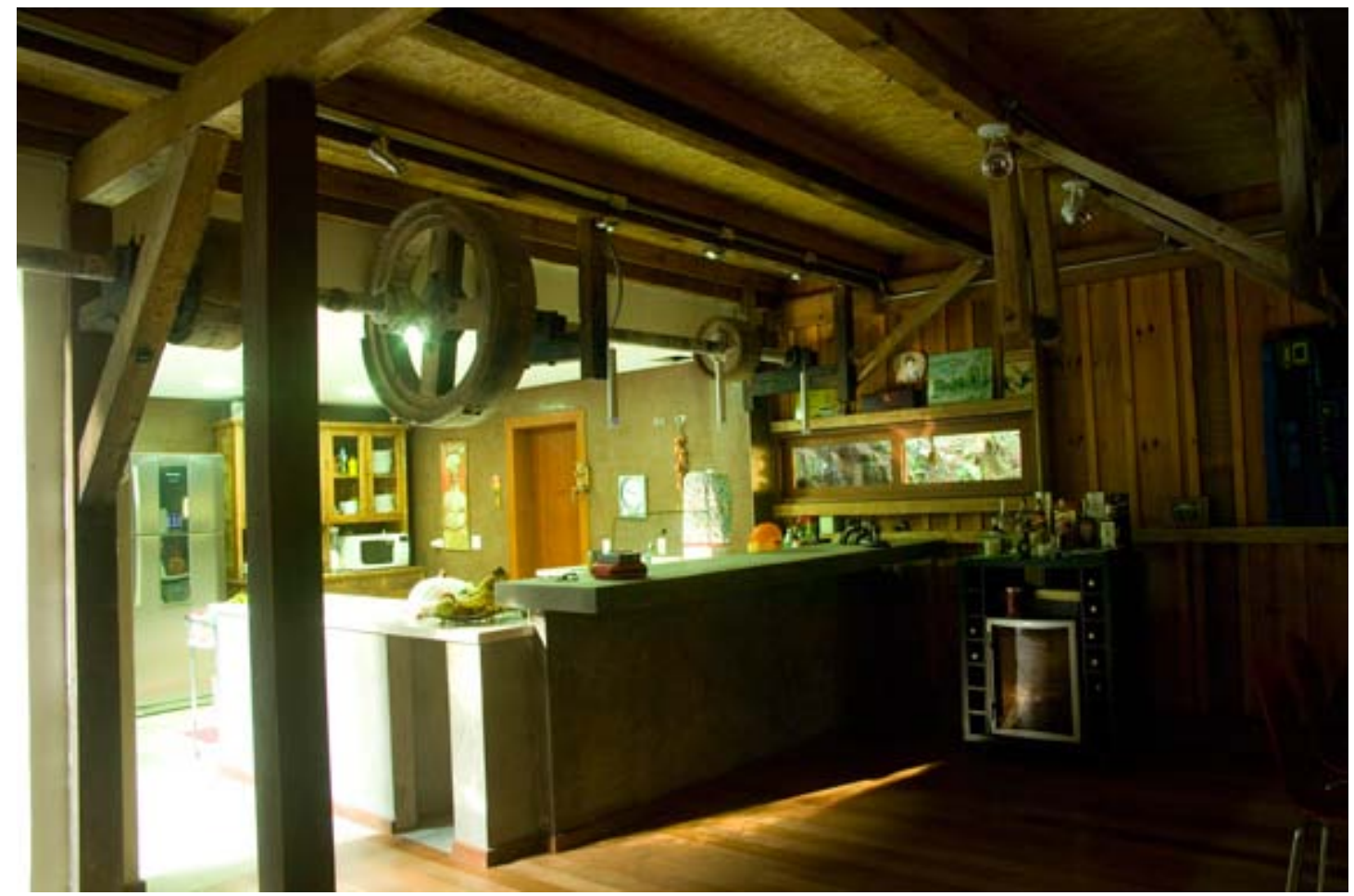

Figura 115 - Casa Almirante Tamandaré: cozinha

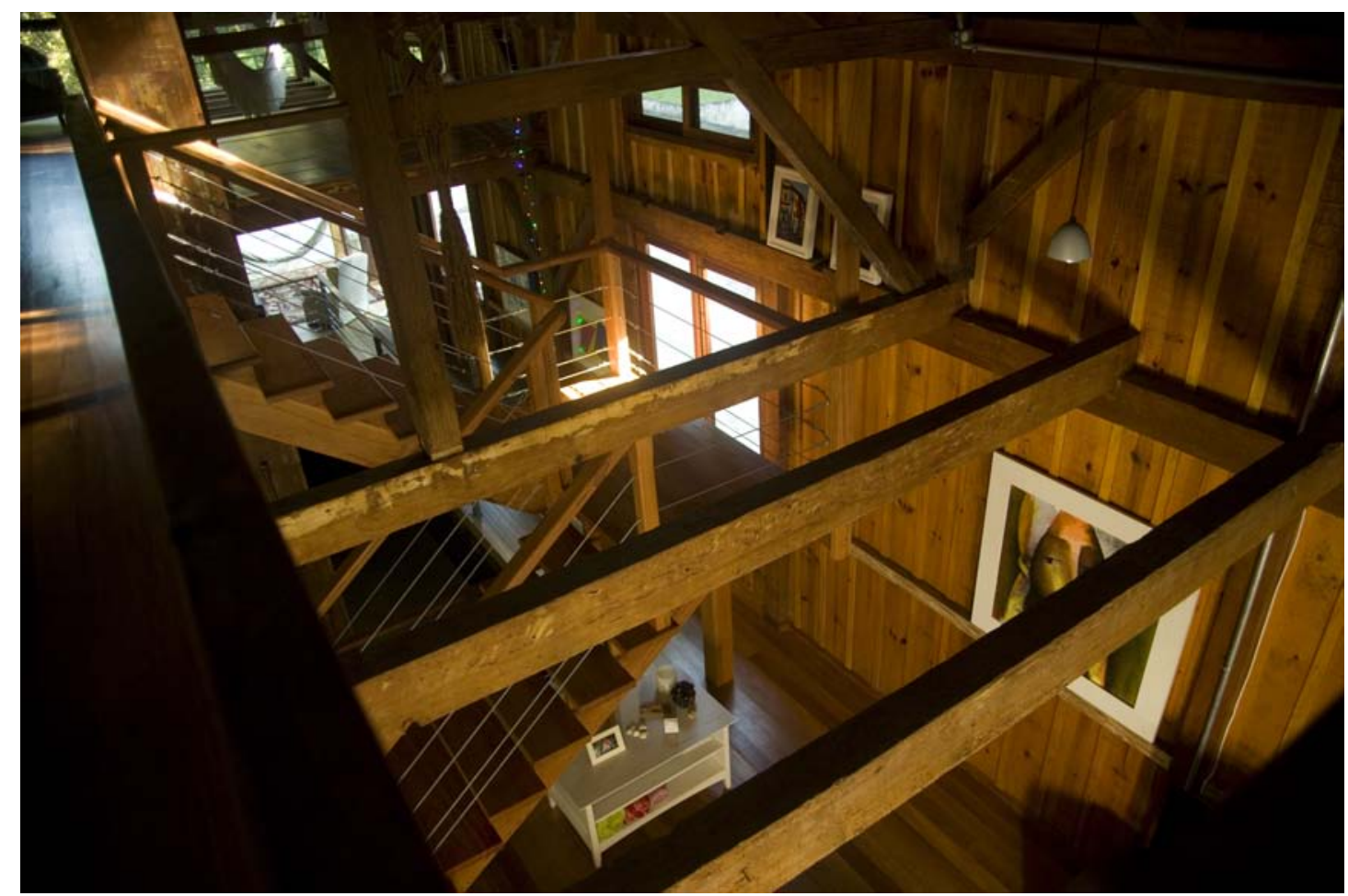

Figura 116 - Casa Almirante Tamandaré: pavimento térreo 


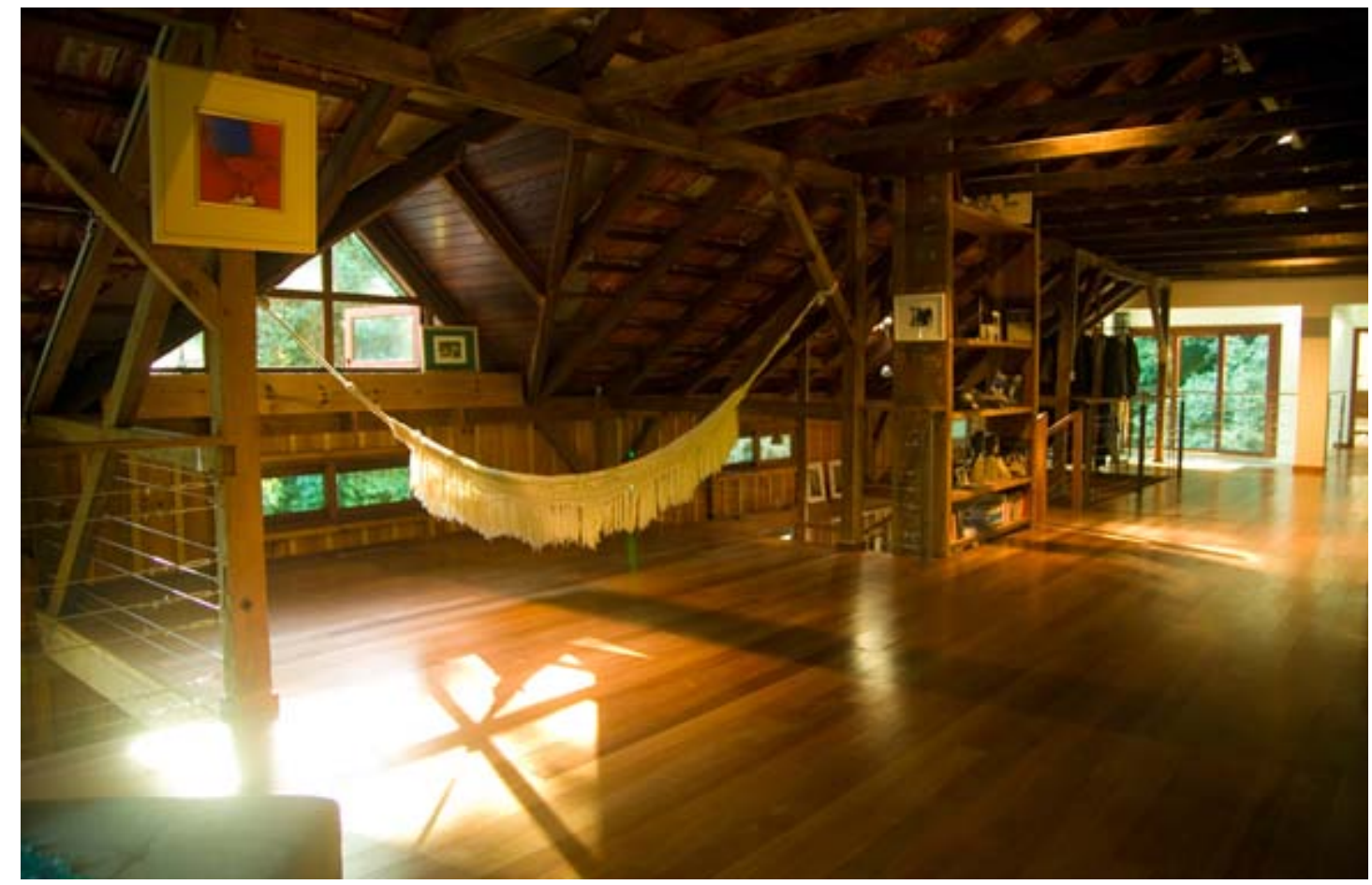

Figura 117 - Casa Almirante Tamandaré: sótão

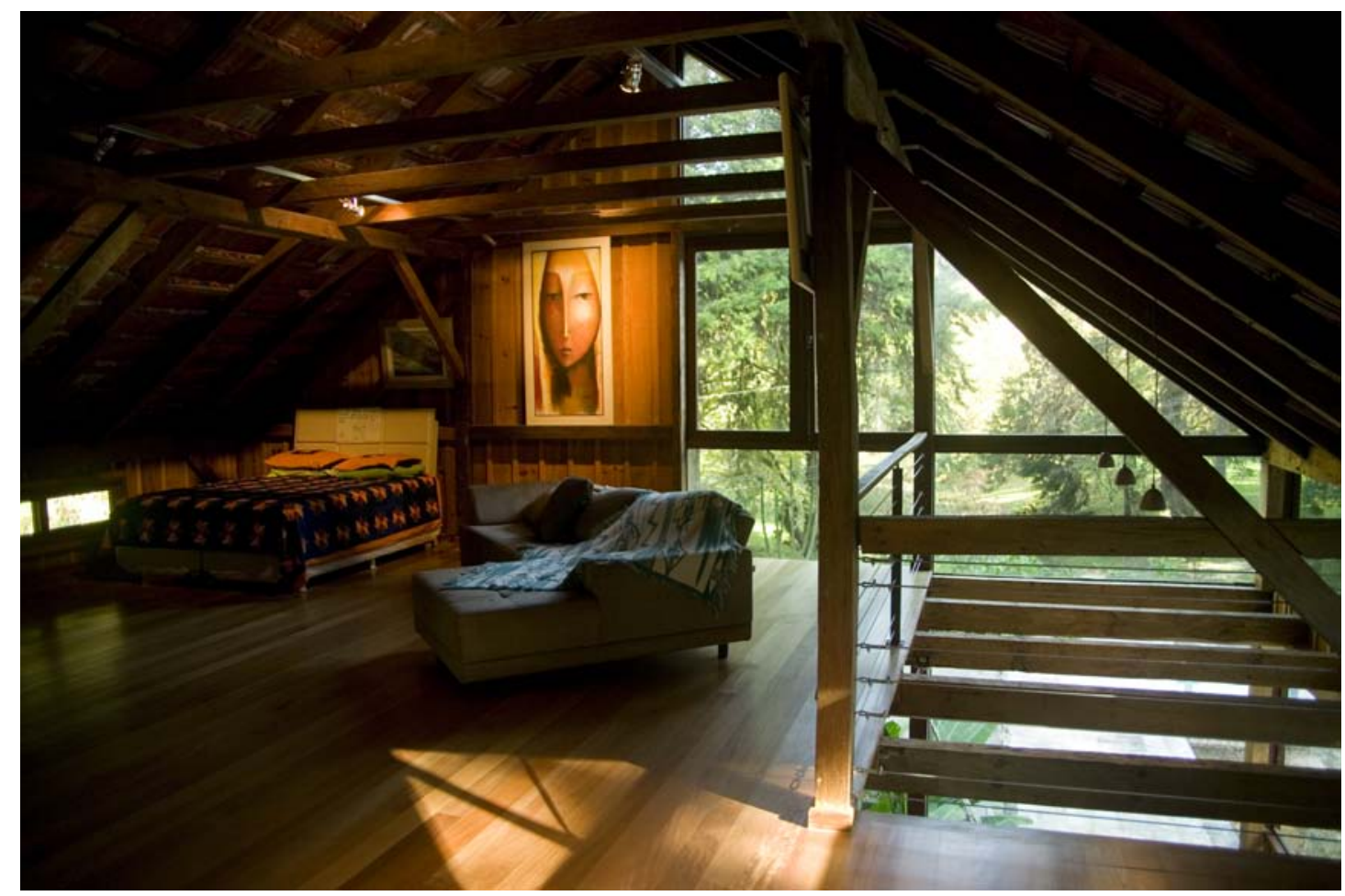

Figura 118 - Casa Almirante Tamandaré: sótão 


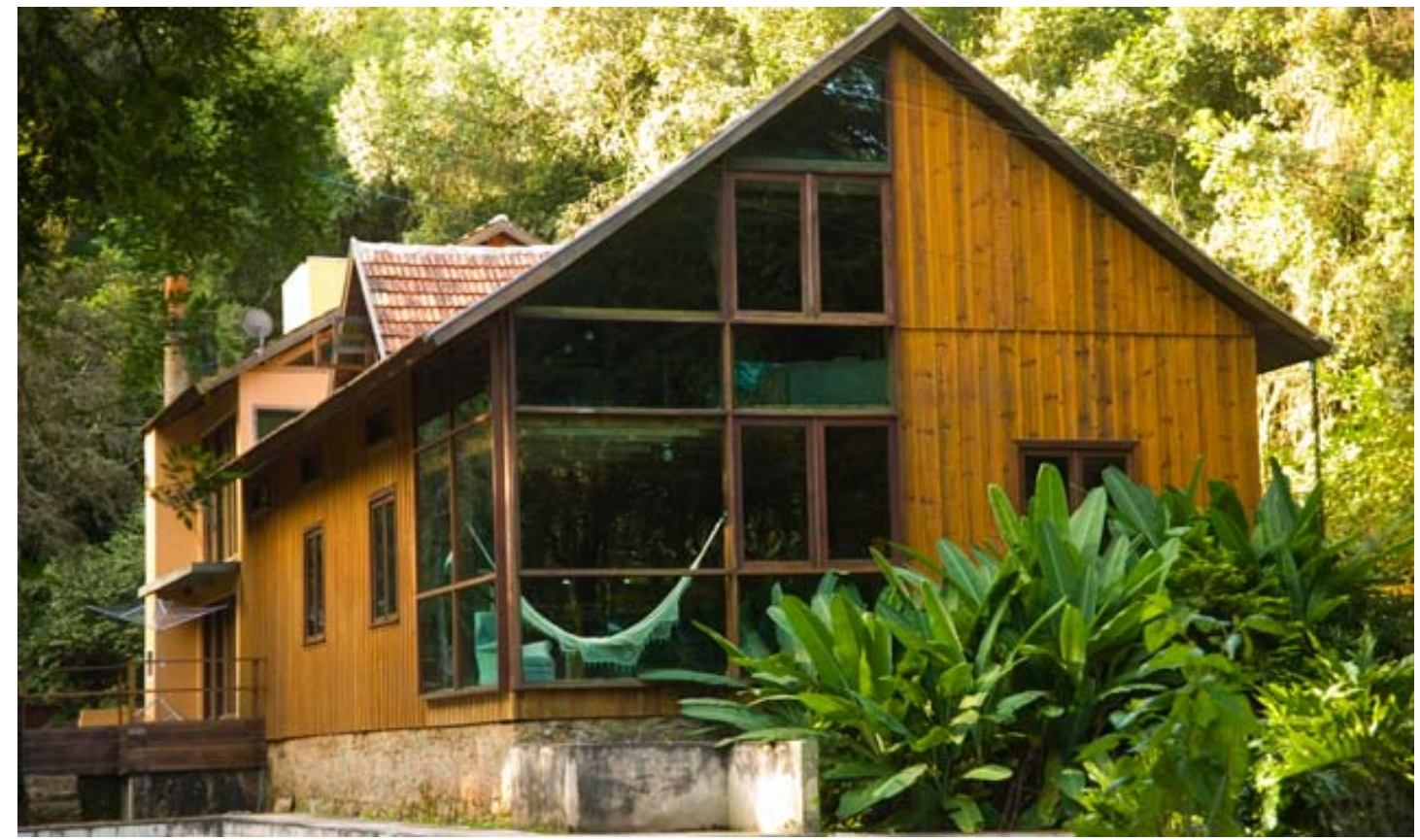

Figura 119 - Casa Almirante Tamandaré: vista externa

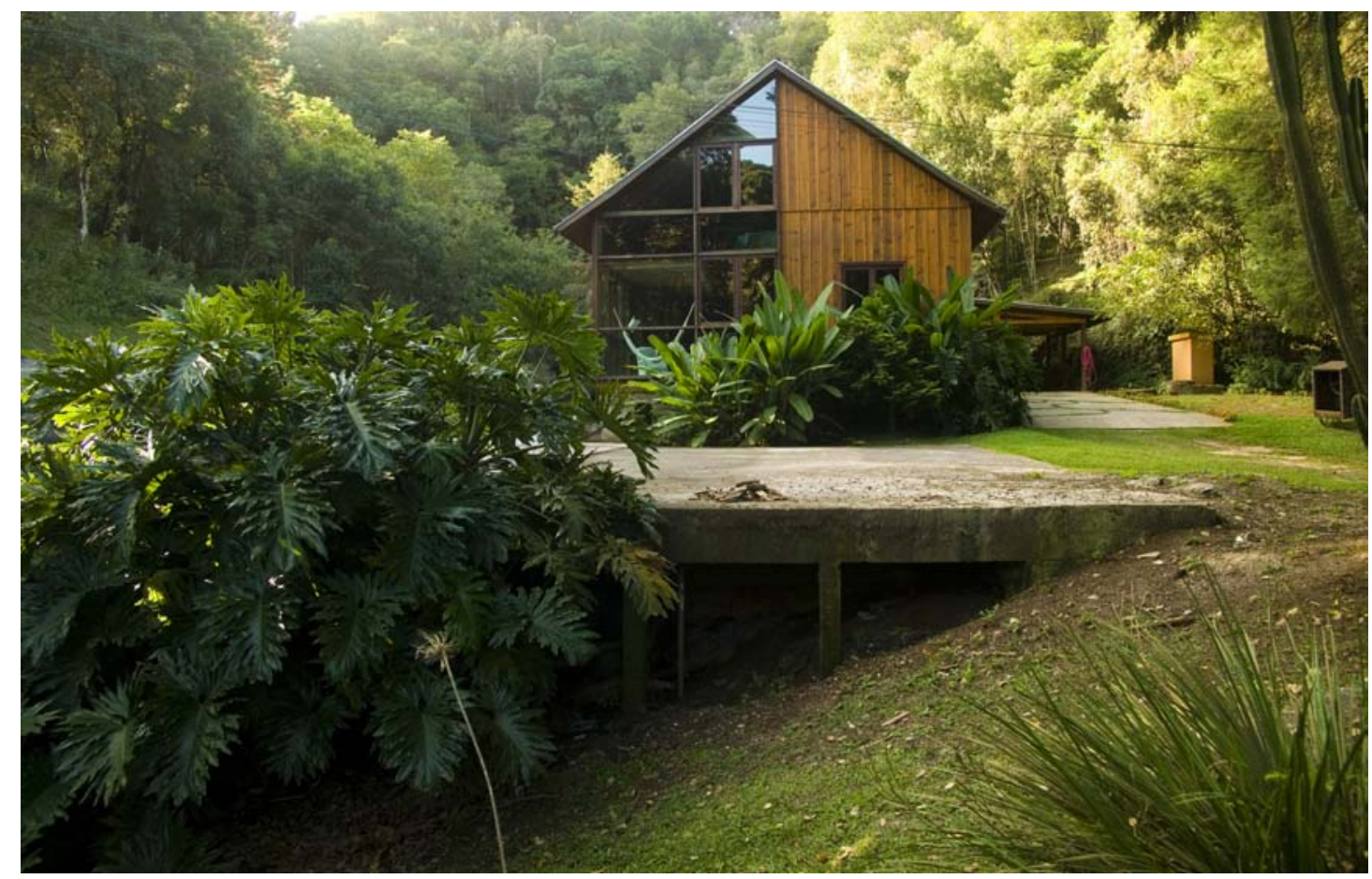

Figura 120 - Casa Almirante Tamandaré: entorno 


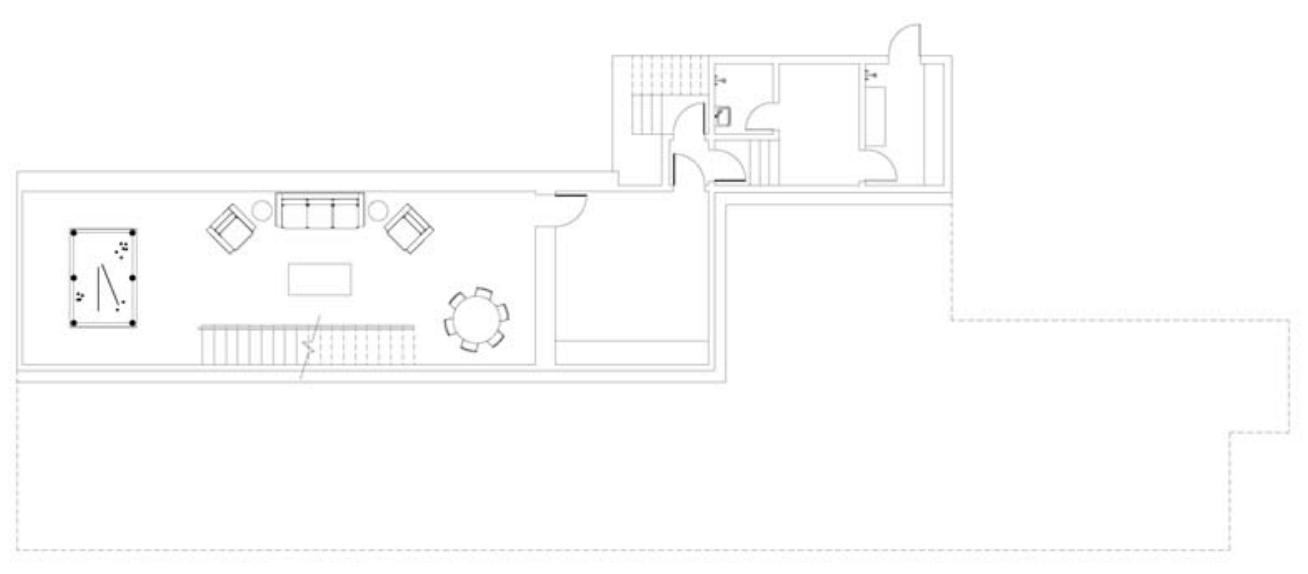

Figura 121 - Casa Almirante Tamandaré: planta subsolo

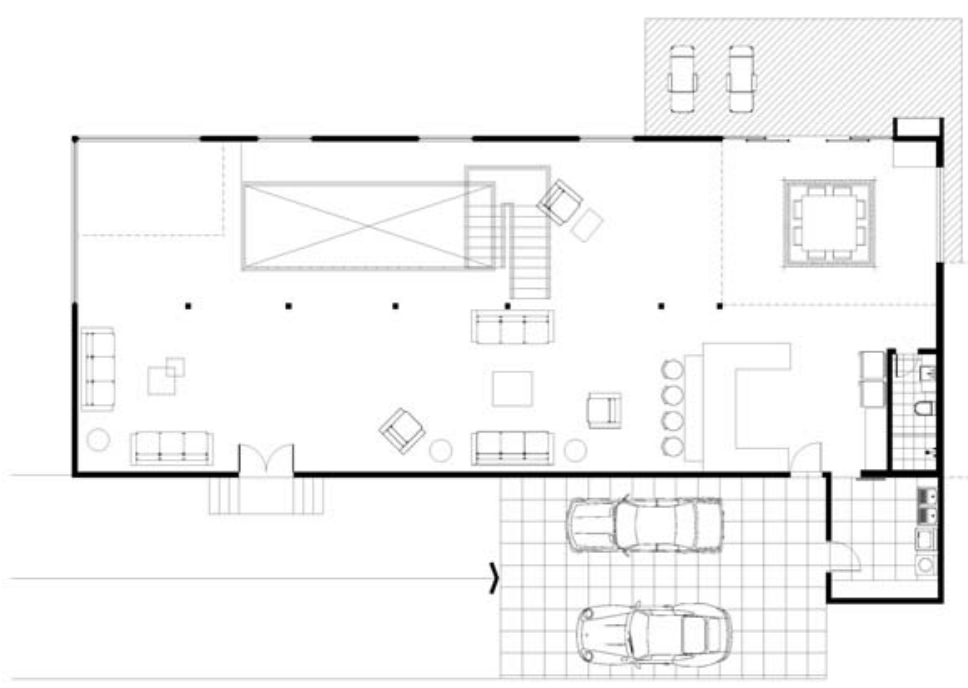

Figura 122 - Casa Almirante Tamandaré: planta pavimento térreo

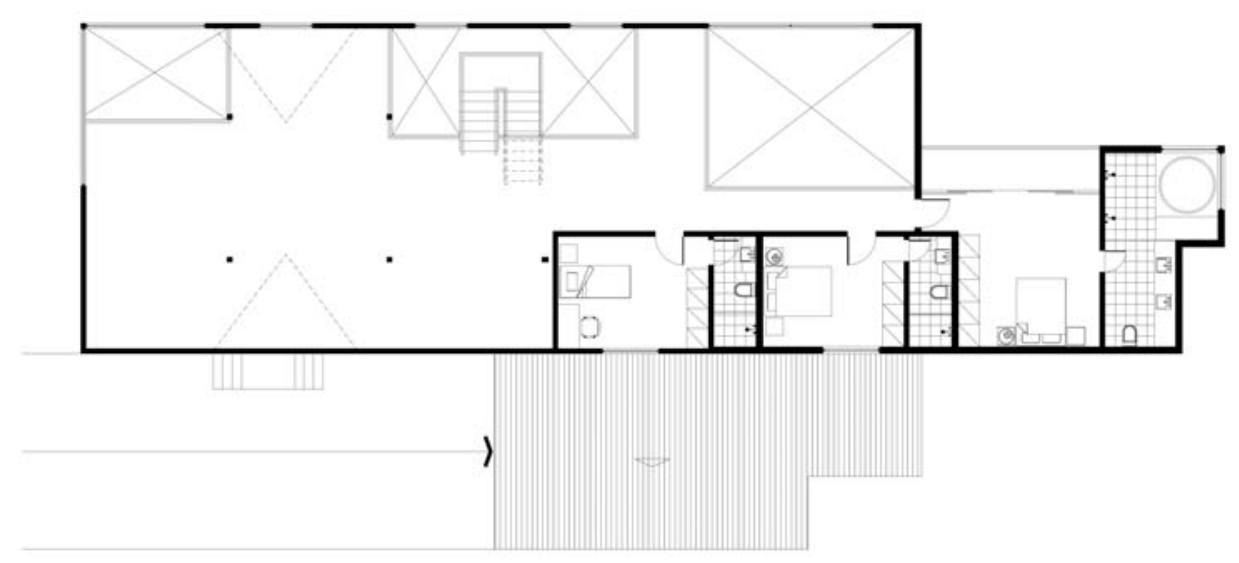

Figura 123 - Casa Almirante Tamandaré: planta pavimento superior 


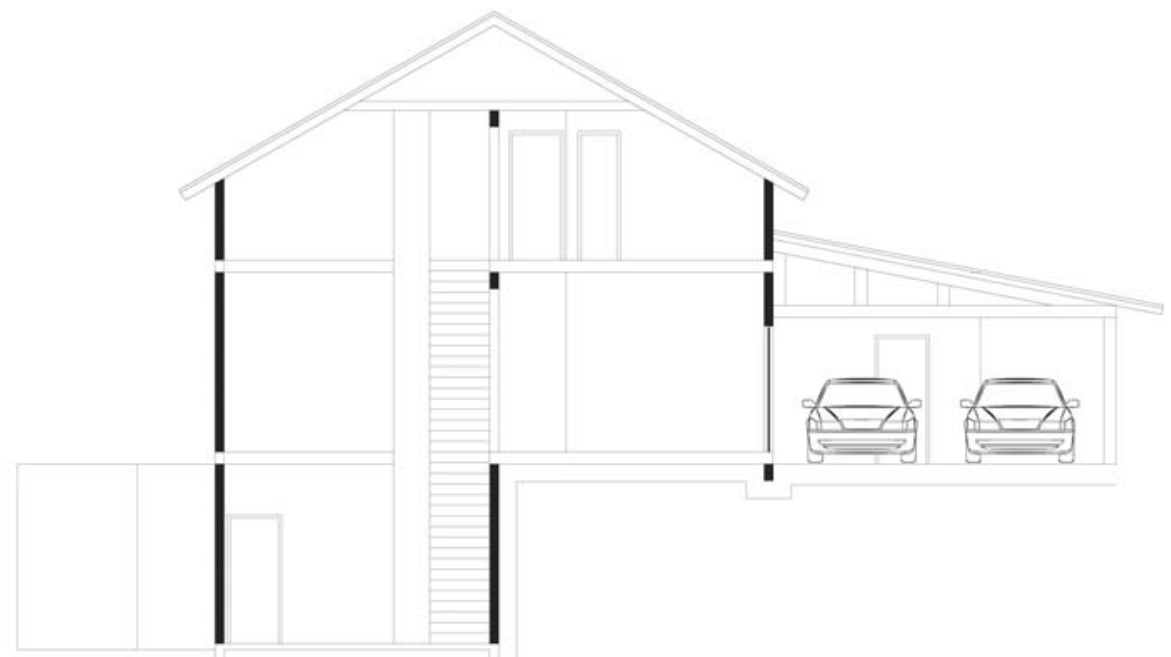

Figura 124 - Casa Almirante Tamandaré: corte

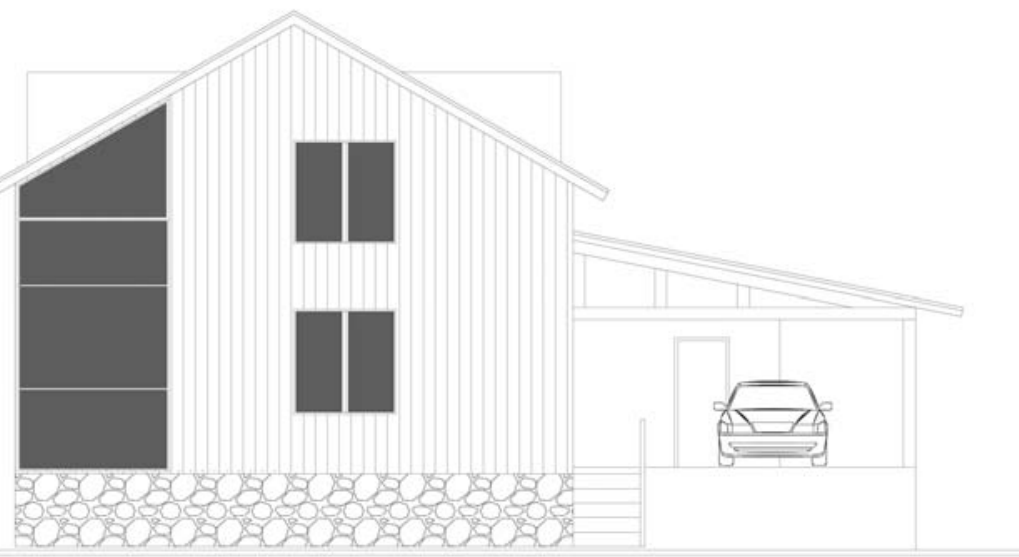

Figura 125 - Casa Almirante Tamandaré: elevação frontal

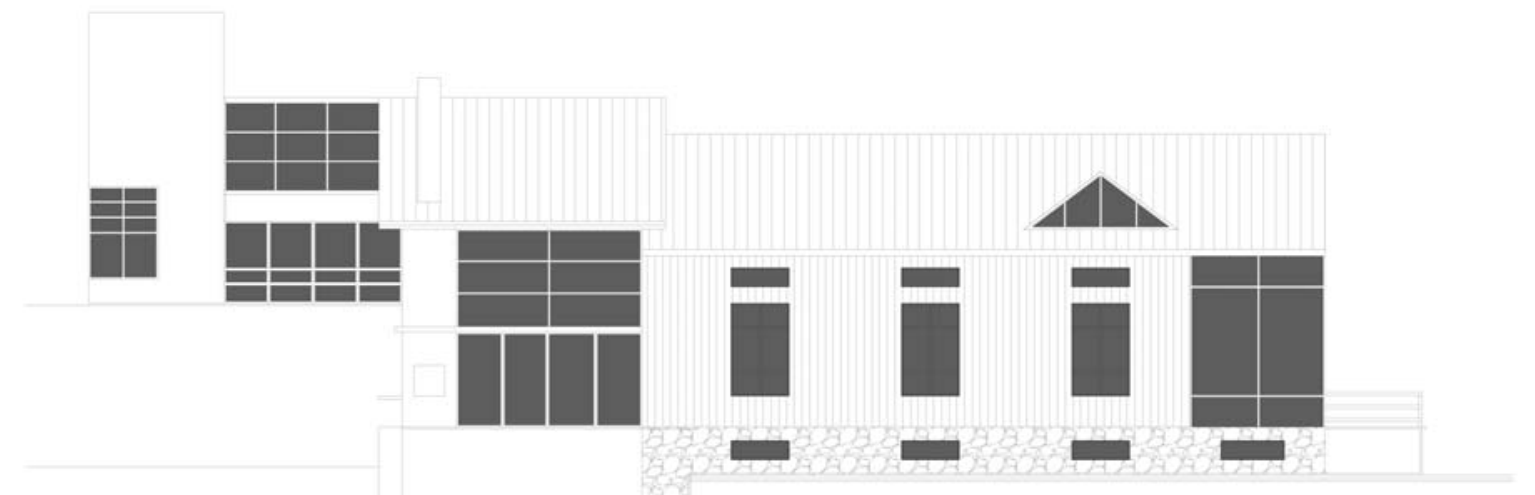

Figura 126 - Casa Almirante Tamandaré: elevação lateral 


\subsection{Visão geral}

Localizado em uma chácara em Almirante Tamandaré, região metropolitana de Curitiba, o antigo moinho com mais de cem anos foi reformulado para se tornar uma residência de $720 \mathrm{~m} 2$. O projeto tem caráter conceitual e é fiel aos primórdios arquitetônicos da construção original.

A paisagem natural permaneceu intocada, depois da reforma estrutural. Originalmente, o moinho localizava-se entre um riacho e o morro e formava uma queda d'água para mover a roda e a turbina.

O conceito do projeto foi estruturado de forma a preservar e mostrar o espaço e as técnicas construtivas da edificação original. A ampliação e as reformas são realizadas com a utilização de novos materiais e conceitos arquitetônicos, buscando alterar o mínimo possível o moinho original, e também diferenciar as intervenções novas da estrutura existente.

A estrutura original há muito tempo sem qualquer manutenção, estava com sustentações de madeira comprometidas e precisou ser reforçada para garantir a segurança da obra. Alguns pilares e vigas precisaram ser refeitos e foi incorporada uma construção anexa em estrutura de concreto e alvenaria. $\mathrm{O}$ arquiteto preservou as engrenagens originais do moinho aparentes, evidenciando o passado da construção. Esta atitude evidencia a preocupação em manter um atitude de contextualismo cultural não somente com o sítio, mas com a tipologia e o uso original do edifício.

\subsection{Implantação e relação com o entorno}

A construção original está localizada no pé de um morro, em terreno relativamente plano. O projeto preservou a maior parte da construção original, com exceção de alguns elementos estruturais que já estavam em estado bastante deteriorado.

O projeto se abre para o entorno através de grande planos de vidro, voltados para a mata que circunda toda a residência. Na construção original, materiais como madeira, pedra e telhas de barro se misturam nas texturas e tons da natureza. 
A novo bloco foi construído nos fundos do antigo moinho, em alvenaria, e seu acabamento externo é em pintura laranja. Este bloco também possui grandes aberturas, emolduradas por esquadrias de madeira. $\mathrm{Na}$ área da sala de jantar, um deck de madeira se estende para área externa trazendo o bosque para o interior da casa.

\subsection{Programa de atividades}

O subsolo da construção foi ocupado por um ambiente de estar / sala de jogos. Este espaço ainda conserva as paredes originais em pedra do antigo moinho. Sem janelas ou aberturas diretas para a área externa, a ventilação / iluminação deste pavimento é feita através do poço de luz e escada, que o conecta com os demais pavimentos da casa.

O pavimento térreo, através do qual é feito o acesso, abriga o estar íntimo, cozinha gourmet e sala de jantar. Neste, a planta é aberta, sem haver paredes ou outros elementos verticais subdividindo o espaço. Este ambiente caracteriza-se pela ampla iluminação natural, que incide através do plano de vidro que ocupa a metade esquerda da fachada frontal da residência.

No interior da casa, é perceptível a transição entre a construção original e o volume novo através da diferença de materiais no piso e nos fechamentos.

No pavimento superior, acomodam-se sob a água furtada três suítes e um espaço aberto, com rede, sofá e cama de casal. Neste ambiente, a estrutura da cobertura e telhas ficam aparentes.

\subsection{Partido arquitetônico}

O partido arquitetônico da obra decorre da postura do arquiteto de preservar o máximo possível da estrutura e características originais do moinho, evidenciando neste processo de requalificação o que pertence a obra original e o que foi construído posteriormente.

Ao adaptar o antigo moinho para uso residencial, o arquiteto buscou manter não somente as características construtivas da obra, mas também manteve peças e 
engrenagens originais do moinho intocadas no interior da casa. Esta decisão faz com que o projeto permaneça fiel não só ao caráter arquitetônico do edifício, mas também do passado histórico da construção. Esta atitude evidencia a preocupação em manter o contextualismo cultural não somente em relação ao sítio, mas também em relação à tipologia e ao uso.

O arquiteto sacrifica alguns aspectos do conforto ambiental da construção para manter-se fiel a origem do edifício. Por se tratar da adaptação de uma construção existente, as aberturas e planos de vidro priorizaram a iluminação e as visuais sobre a orientação de cada ambiente da casa. Contudo, isso não compromete de forma grave a residência, uma vez que a vegetação existente também mantida intacta - controla a incidência da luz solar.

Na parte nova, observa-se a preocupação do arquiteto em não contrastar de forma drástica com o moinho original, apenas diferenciar o anexo de forma a não ser confundido com a construção existente.

\subsection{Sistema construtivo}

Na parte correspondente ao moinho, foi preservada a estrutura original em madeira. O bloco anexo também possui a cobertura em estrutura de madeira, entretanto os apoios são em alvenaria.

O revestimentos de piso e paredes diferenciam a construção original do anexo construído posteriormente: assoalho e paredes de madeira na área correspondente ao moinho, cimento queimado e alvenaria branca na construção mais recente.

Estrutura, instalações elétrica e hidráulicas ficam aparentes na maior parte da obra. $\mathrm{O}$ arquiteto buscou deixar em evidência as engrenagens do antigo moinho que ainda não haviam sido deterioradas pelo tempo. Desta forma, preserva-se não somente a técnica construtiva, mas também passado histórico e a função original da construção.

\subsection{Intenção Plástica}


Em termos plásticos, a intervenção procura manter as características estéticas do moinho de mais de cem anos. Construído com materiais locais, as texturas da madeira, pedra, e cobertura em telhas de barro se confundem com as texturas do entorno do local.

No interior da residência, o arquiteto tira proveito da plasticidade dos materiais rústicos e da estrutura / instalações aparentes. Engrenagens antigas foram preservadas e deixadas a mostra em todo pavimento térreo. $\mathrm{O}$ arquiteto mantém a configuração original da planta aberta do antigo moinho, fazendo uso de elementos verticais de separação dos ambientes somente quando estritamente necessário.

Nesta planta aberta, o ponto focal acaba sendo a escada, elemento escultórico em madeira com guarda-corpo em madeira e cabos de aço. É ela que funciona como elemento de divisão entre espaços da casa e conecta todos os pavimentos.

O interior da casa é marcado pelo jogo de luz e sombra entre os planos de vidro, os pilares de madeira e as tesouras aparentes da cobertura. 
13. DANIELA BUSARELLO: RESIDÊNCIA DA ARQUITETA

Rua João Leal, Curitiba, Paraná

Arquitetos: Daniela Busarello

Projeto: 2001

Conclusão: 2003

Estrutura Metálica: Brafi

Engenheiro: Dalton Abreu

Vidros: Temparaito

Vedações: Brick Wall

Esquadrias: Kommerling

Área: $400,00 \mathrm{~m} 2$

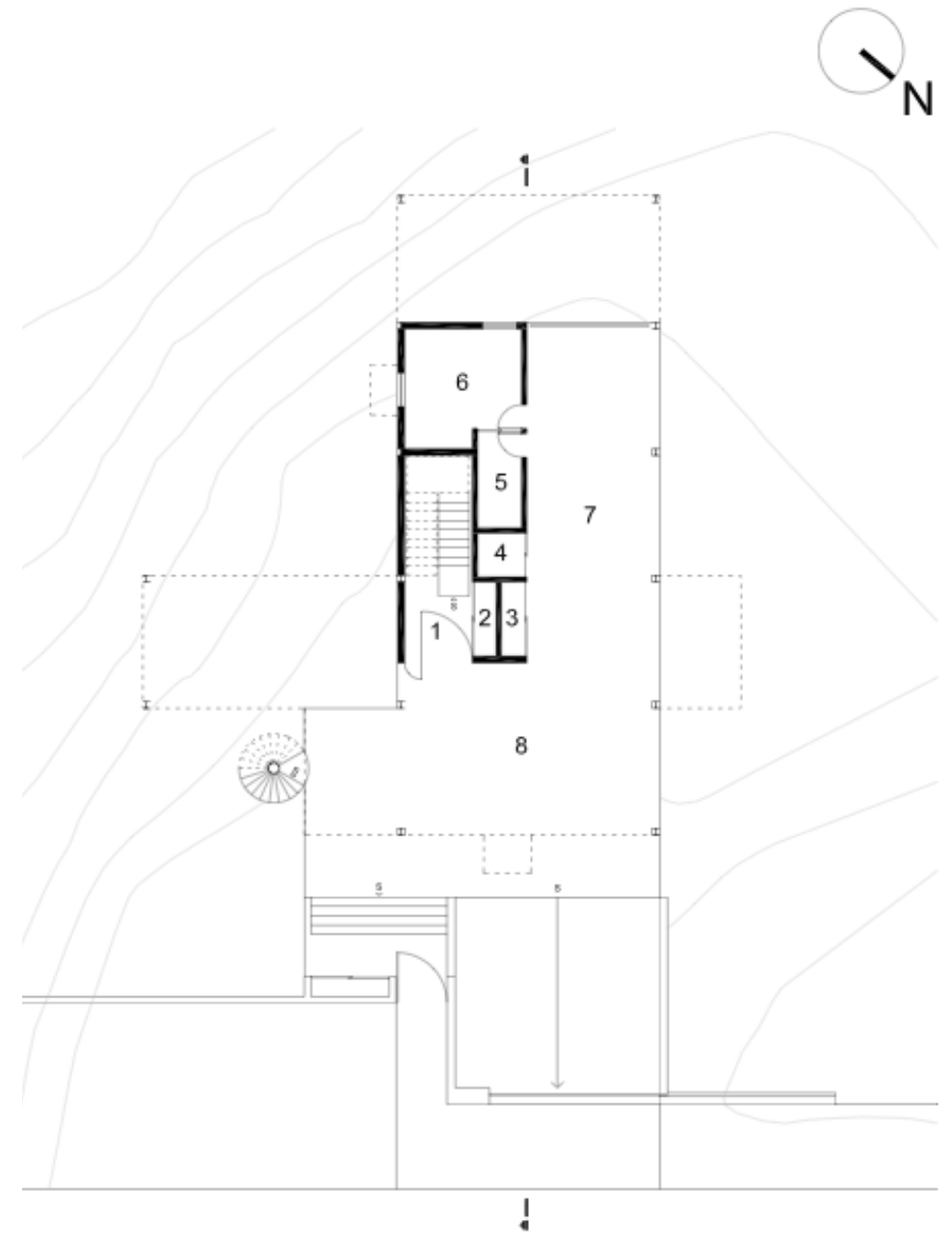

Figura 127 - Residência Daniela Busarello: planta pavimento térreo 

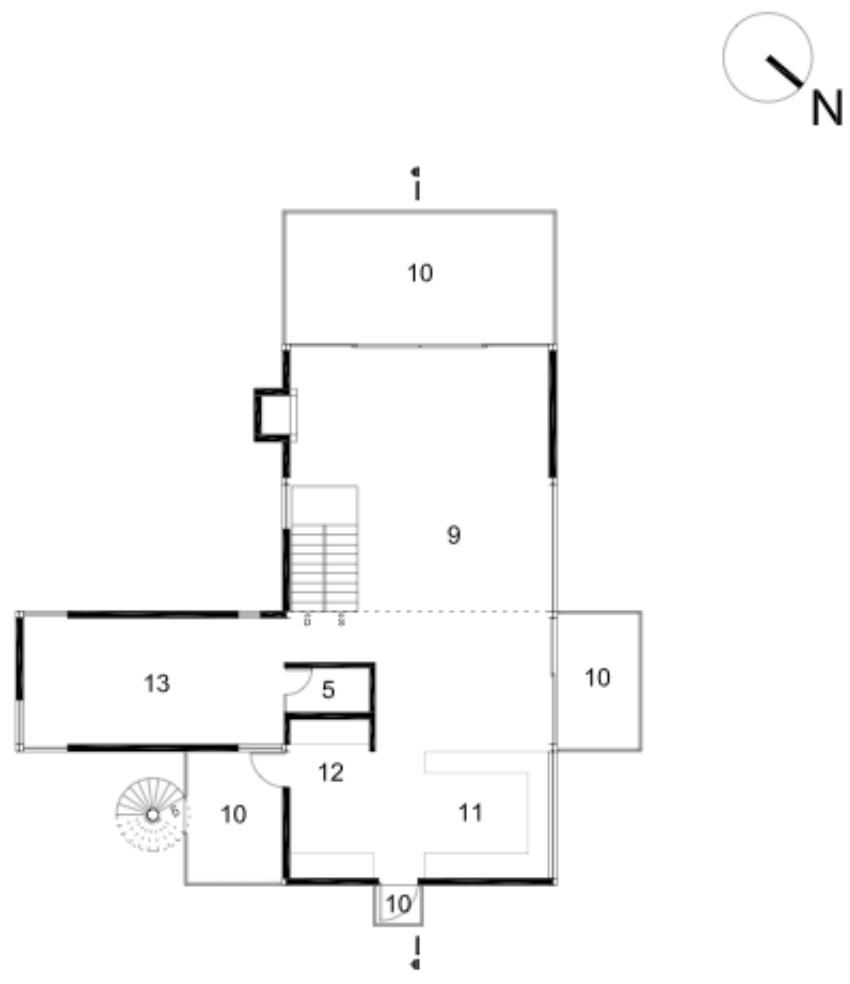

Figura 128 - Residência Daniela Busarello: planta primeiro pavimento

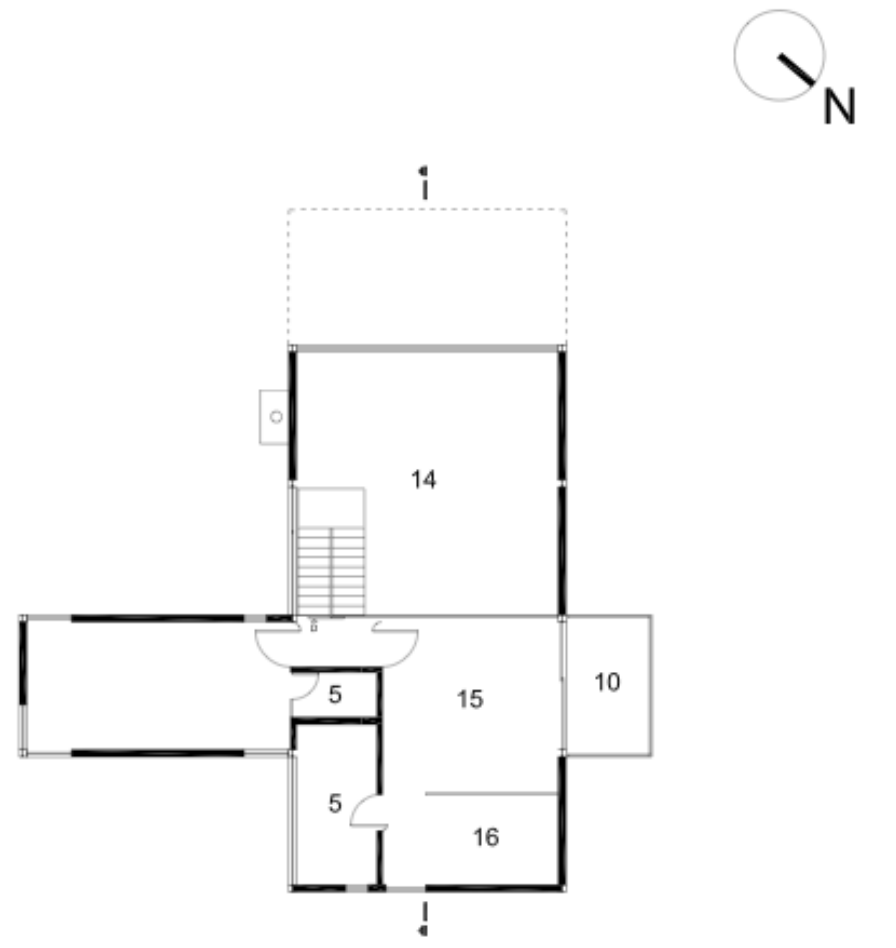

Figura 129 - Residência Daniela Busarello: planta segundo pavimento 


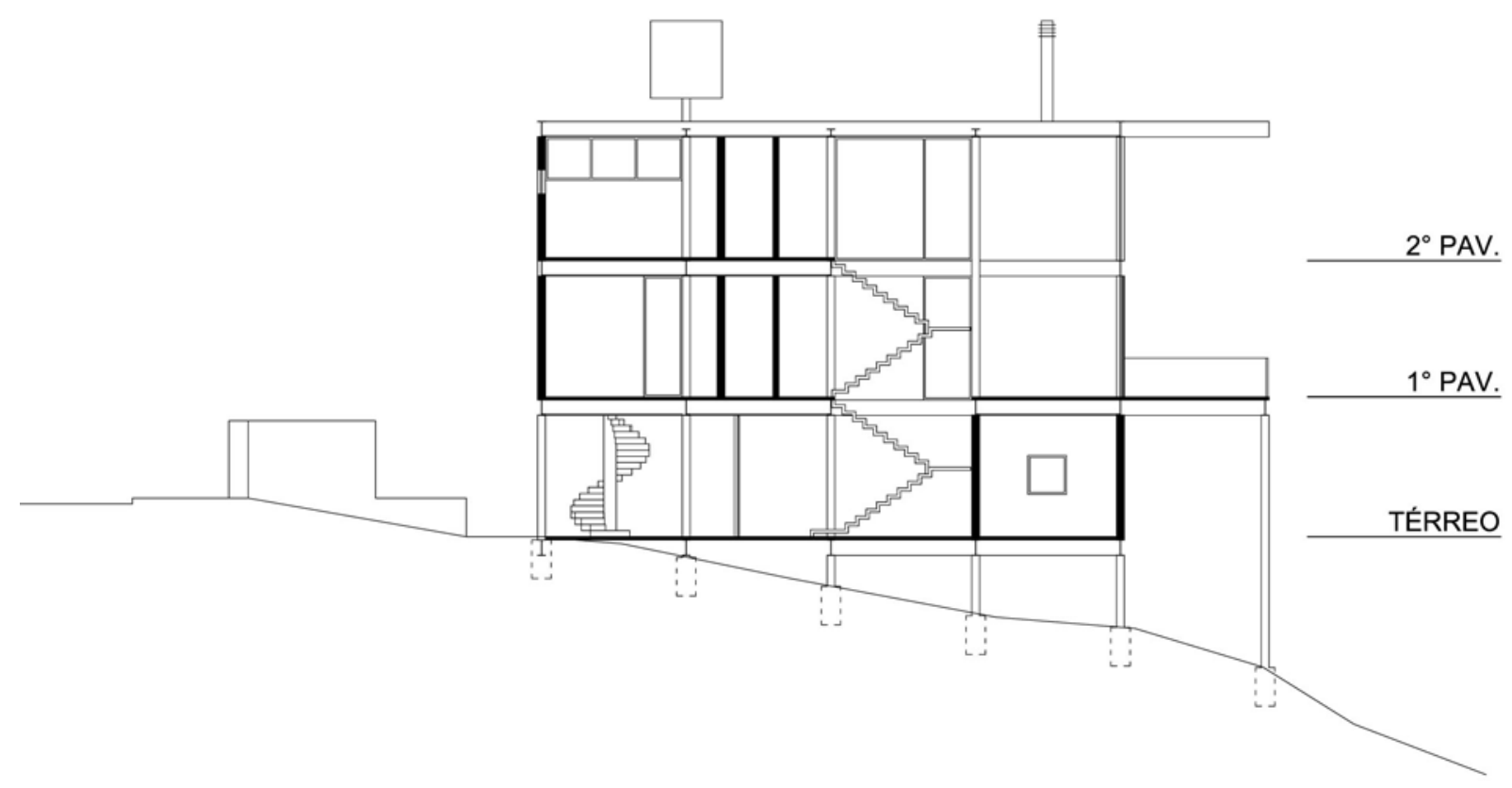

Figura 130 - Residência Daniela Busarello: corte longitudinal

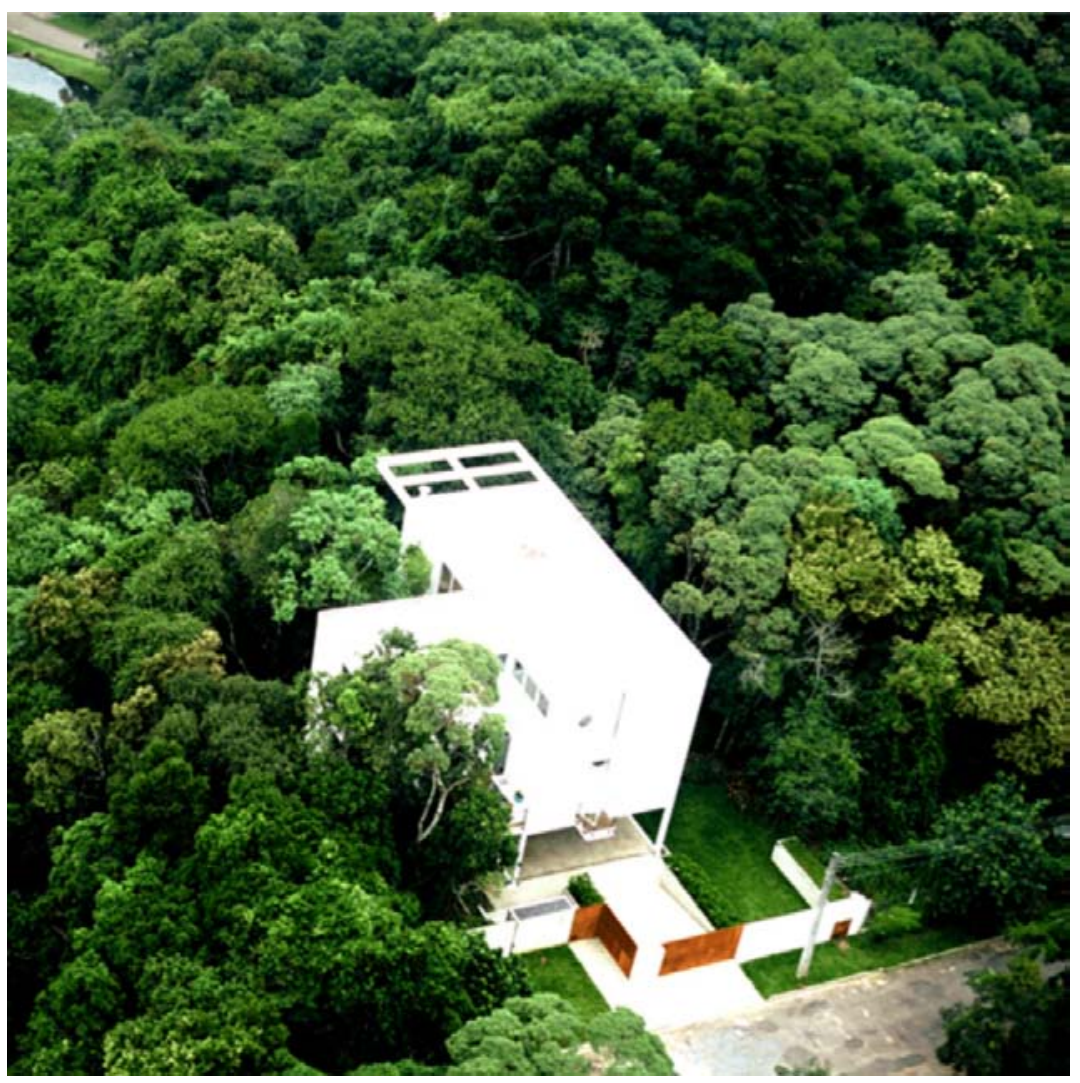

Figura 131 - Residência Daniela Busarello: vista geral 


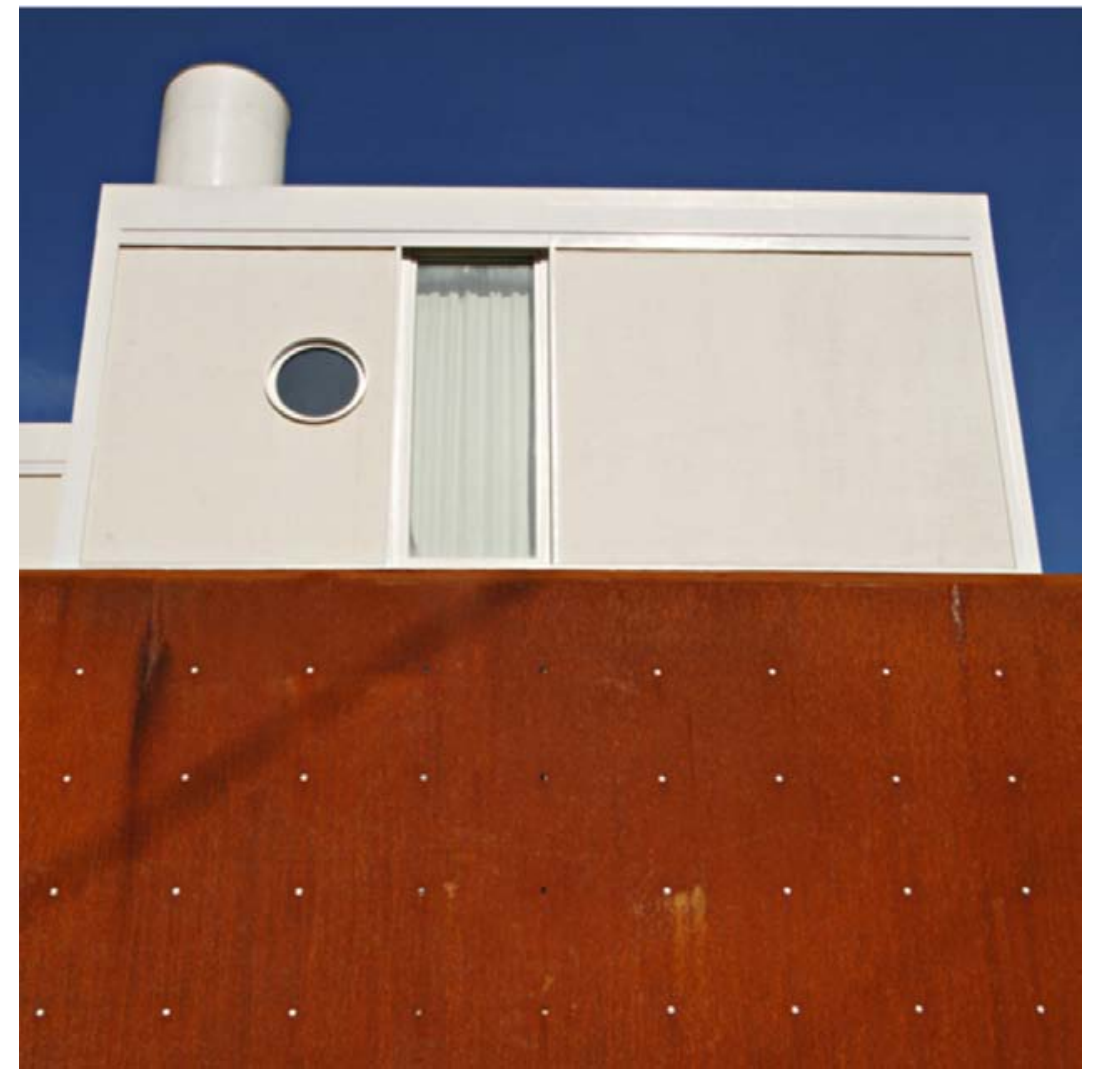

Figura 132 - Residência Daniela Busarello: entrada principal

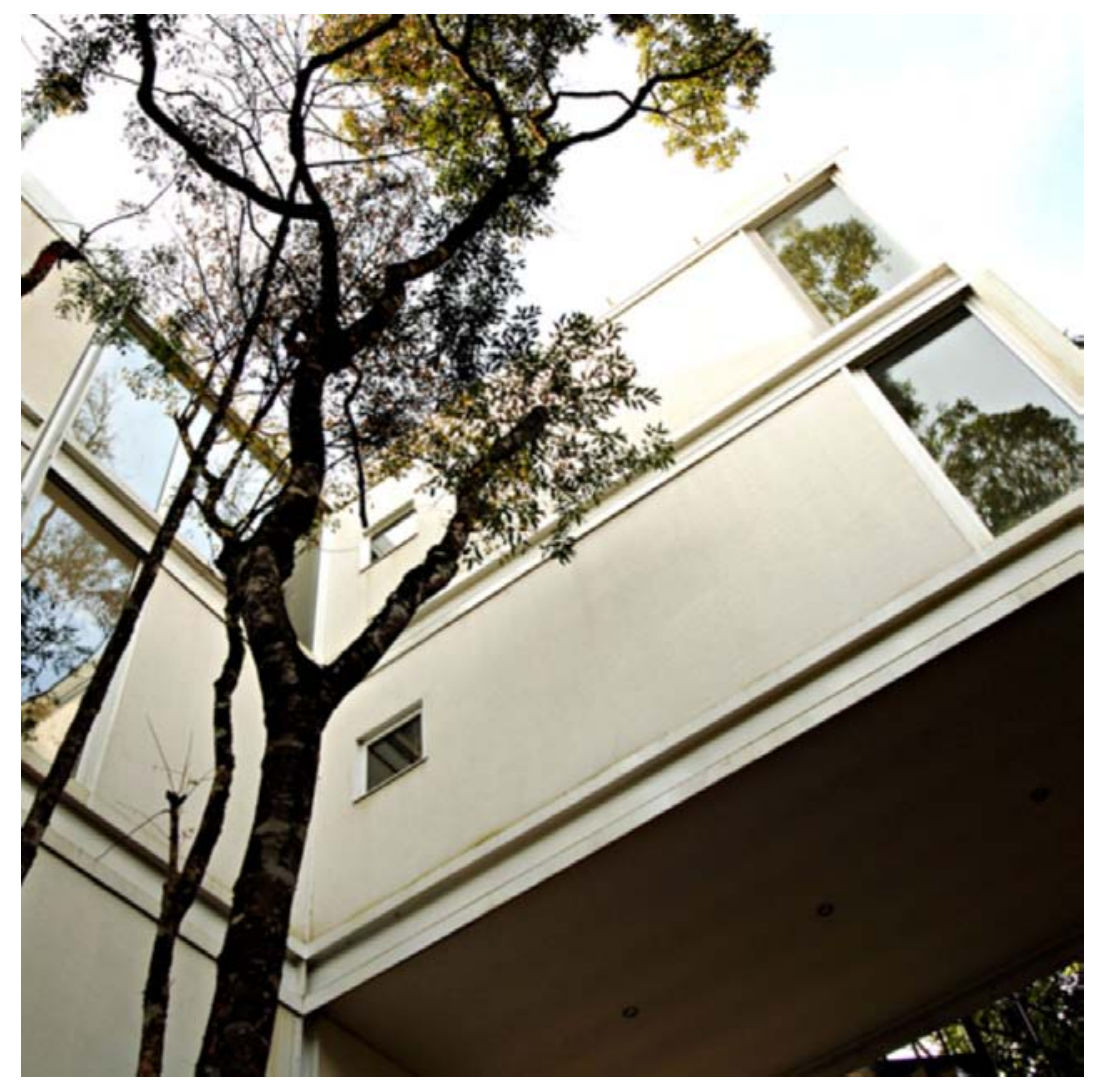

Figura 133 - Residência Daniela Busarello: perspectiva externa 


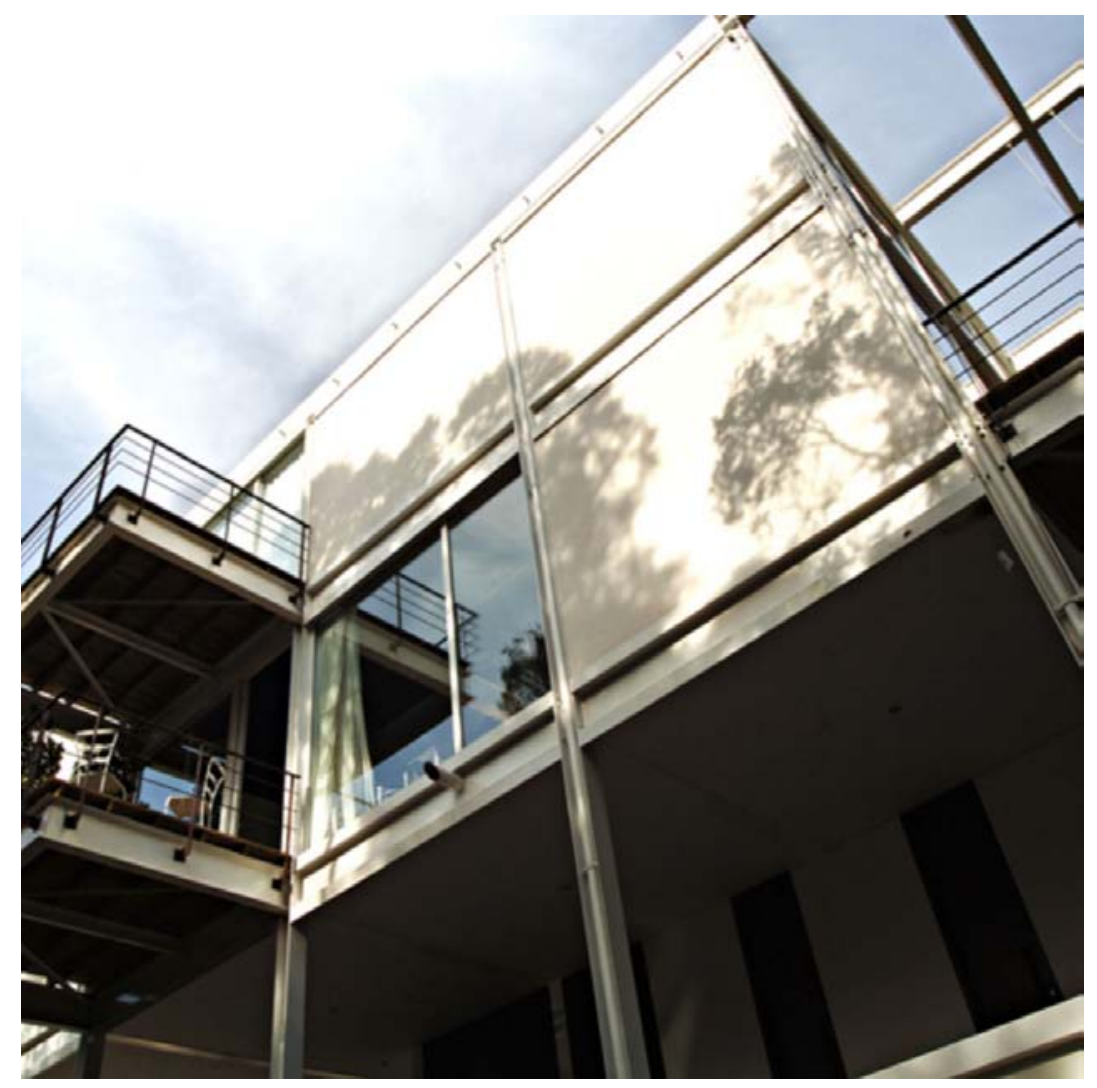

Figura 134 - Residência Daniela Busarello: terraços

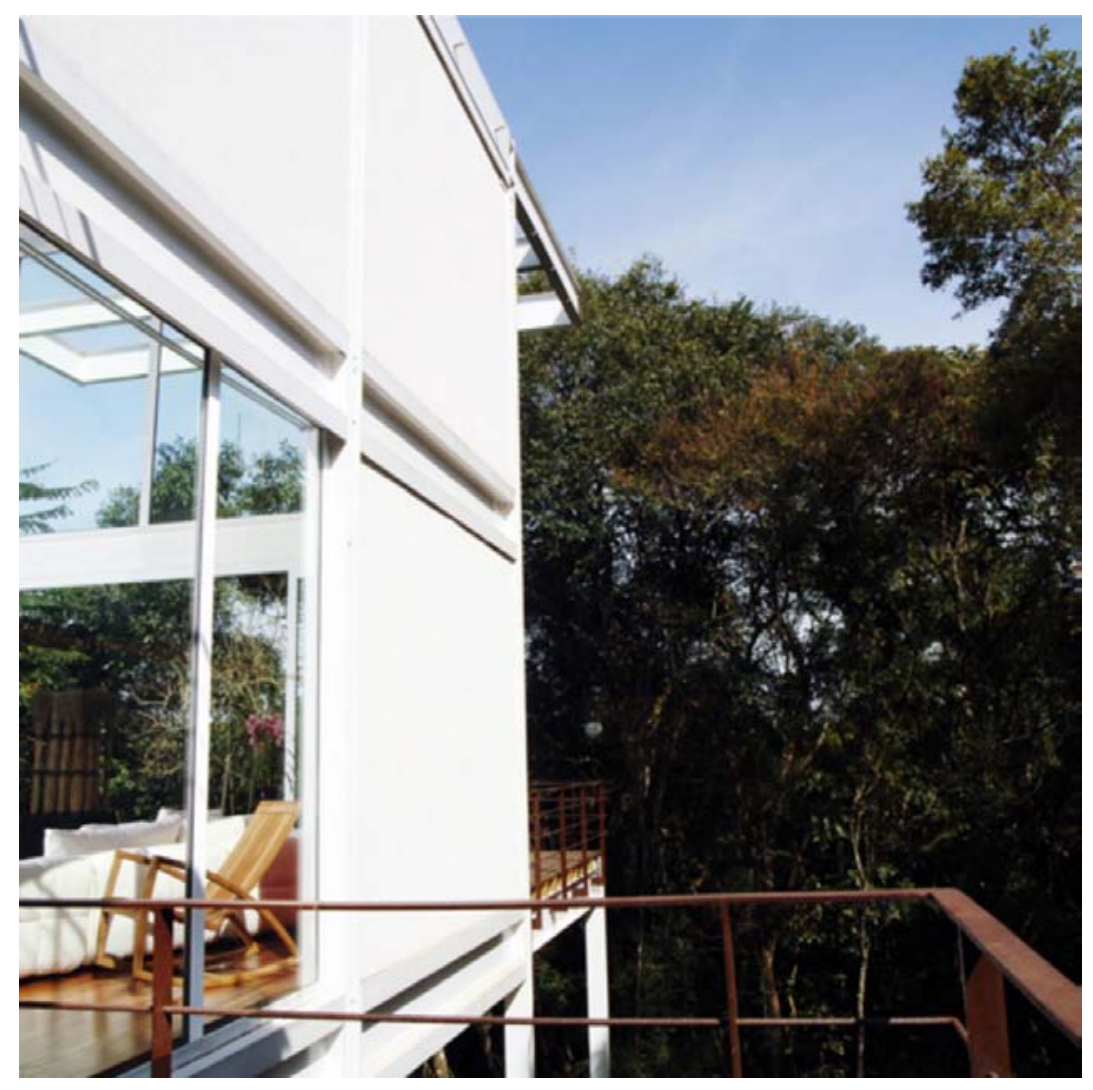

Figura 135 - Residência Daniela Busarello: detalhe estrutura metálica 


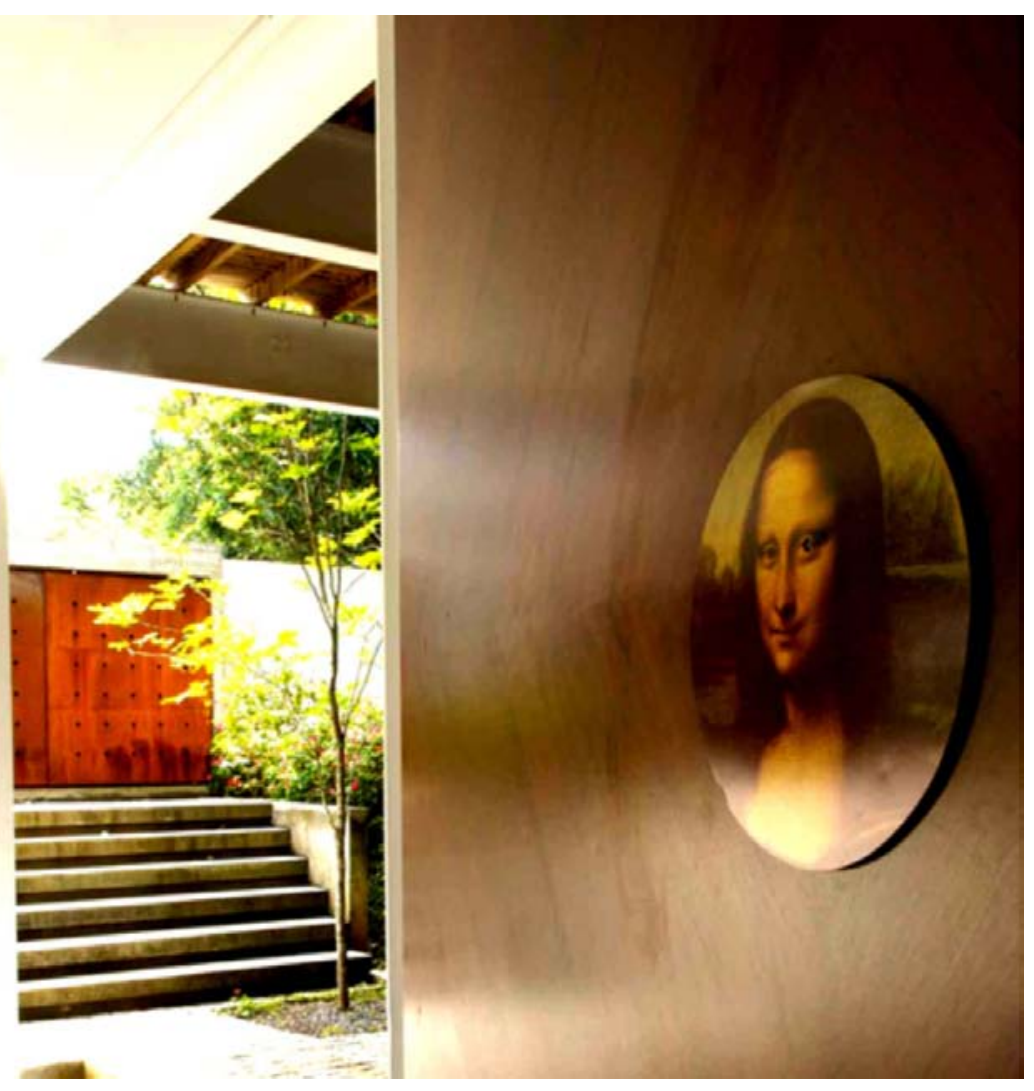

Figura 136 - Residência Daniela Busarello: hall

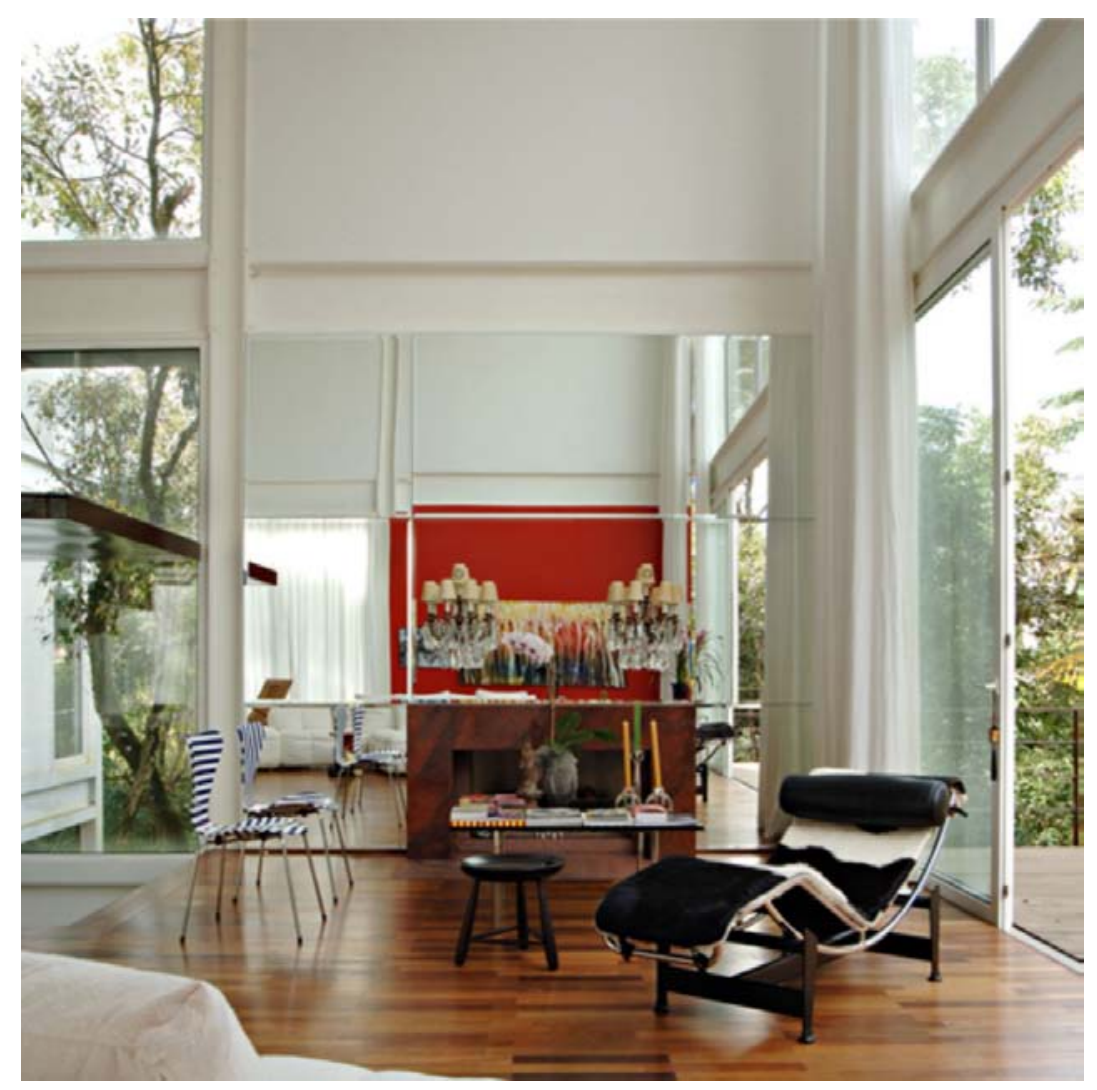

Figura 137 - Residência Daniela Busarello: sala 


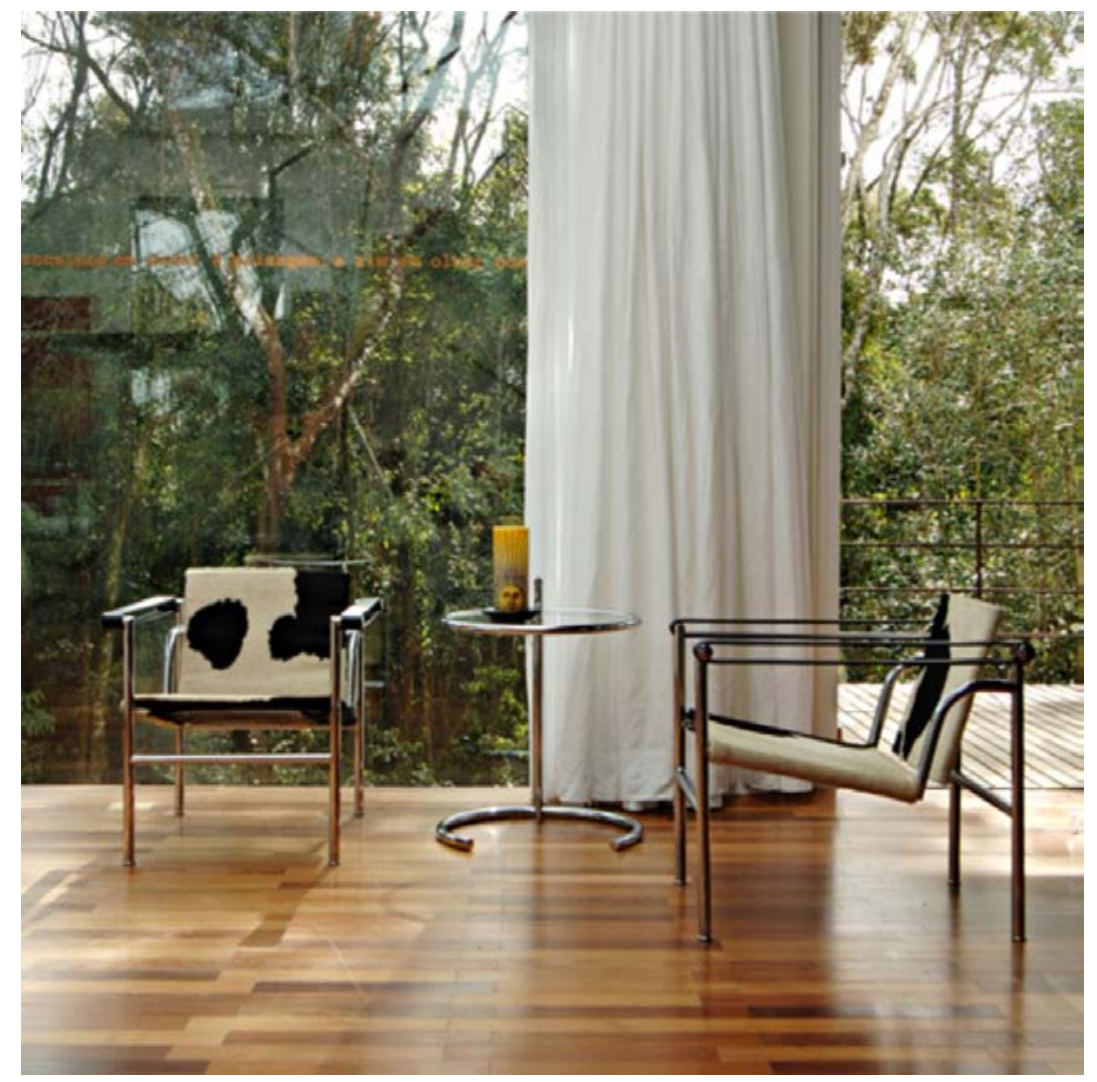

Figura 138 - Residência Daniela Busarello: interior e bosque

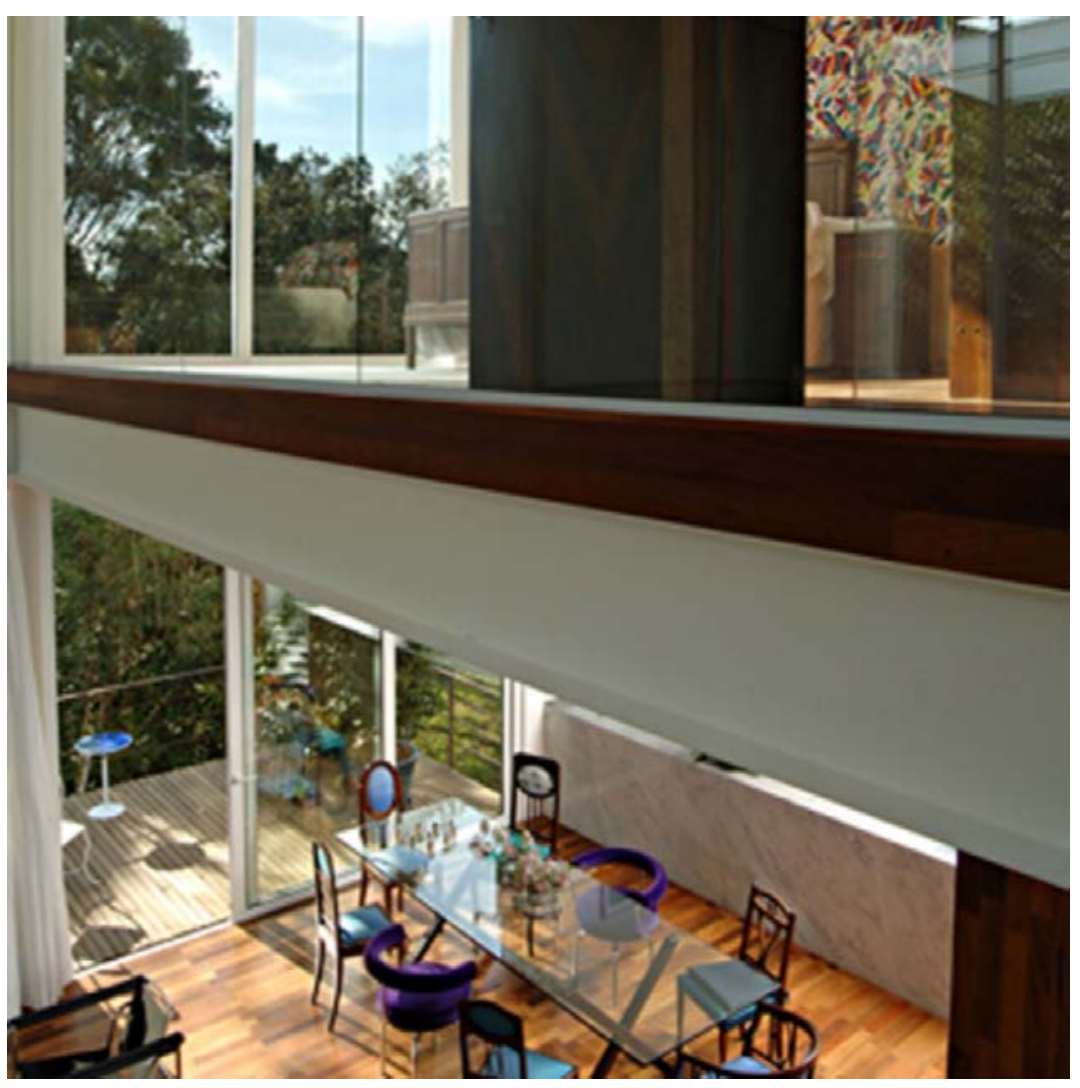

Figura 139 - Residência Daniela Busarello: sala de jantar 


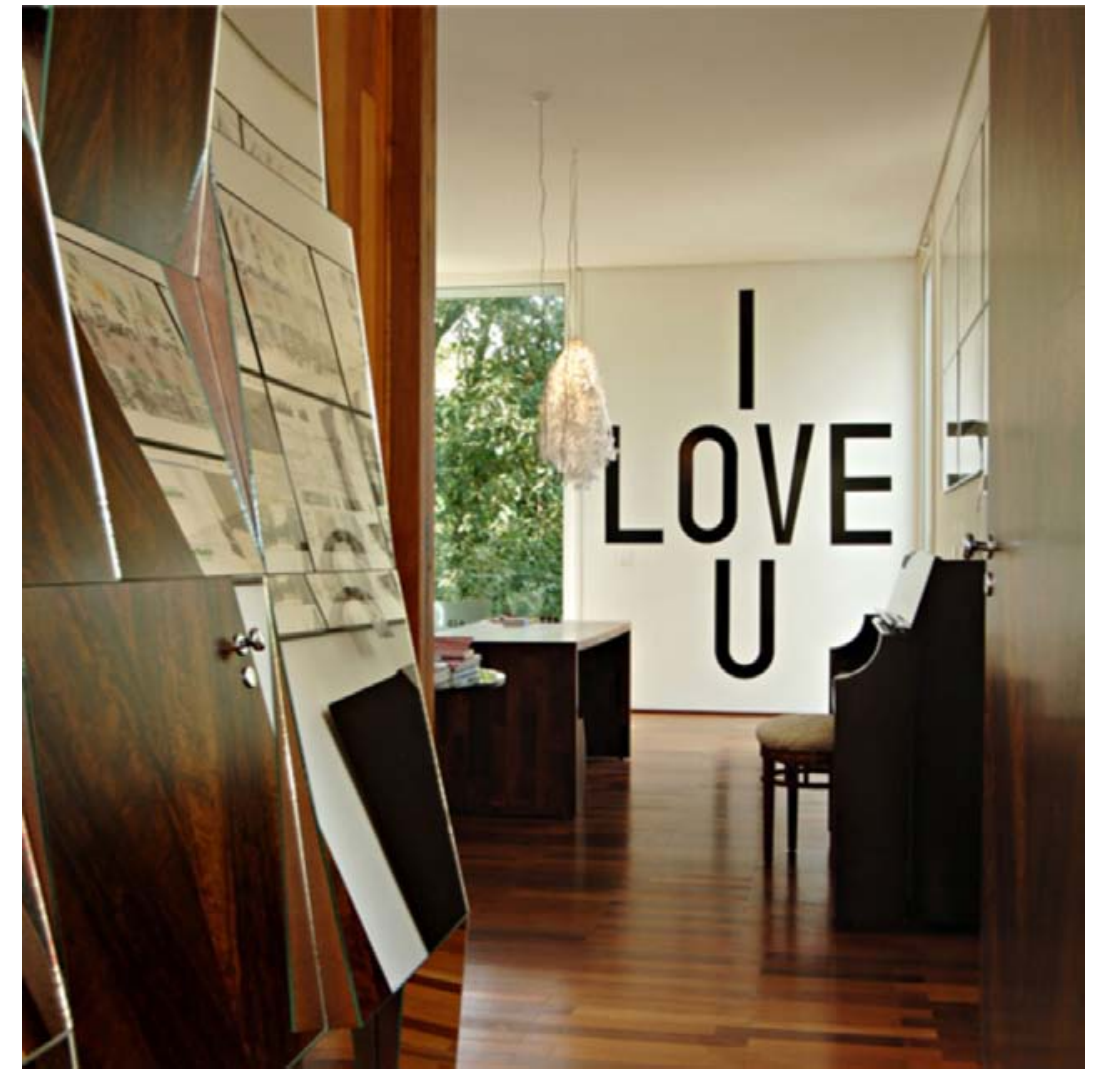

Figura 140 - Residência Daniela Busarello: detalhe

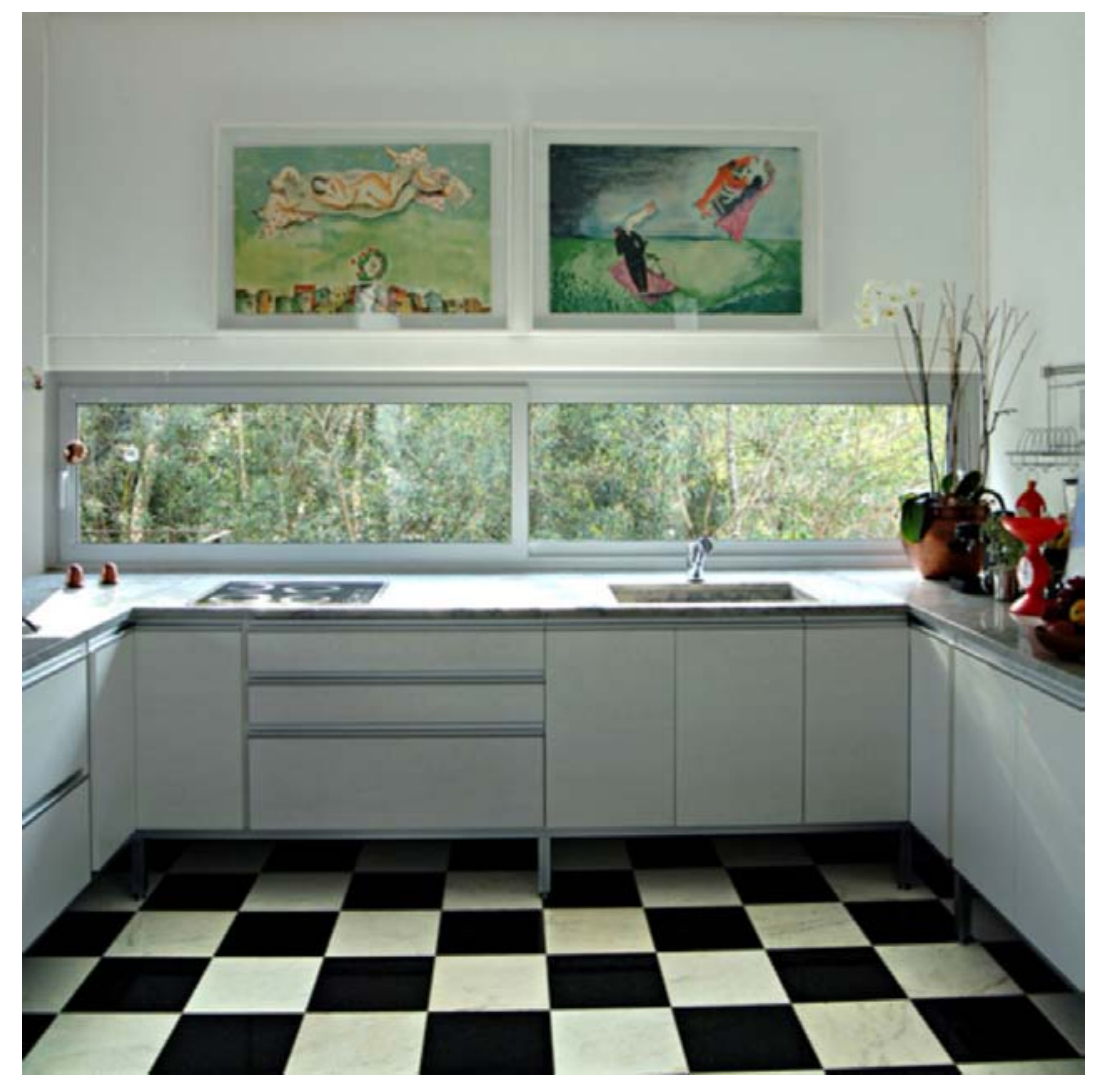

Figura 141 - Residência Daniela Busarello: cozinha 


\subsection{Visão geral}

Esta residência de 400 m2 encontra-se em uma localização privilegiada de Curitiba, inserida em um bosque nas proximidades do Parque São Lourenço, uma grande área verde no centro da cidade. Construída em um terreno com 14 metros de desnível, a residência procurou aproveitar ao máximo a iluminação natural e se integrar a densa vegetação do entorno. As decisões de projeto foram tomadas sempre buscando preservar tanto quanto o possível o bosque à sua volta.

O projeto buscou uma solução de implantação rápida e uso racional dos materiais, minimizando o impacto da construção da obra no meio ambiente. Por este motivo, optou-se pelo uso da estrutura metálica. A montagem dos perfis foi realizada em apenas quatro dias.

Para as vedações, foram utilizadas chapas de concreto e poliuretano, proporcionando uma execução dinâmica, limpa e de baixo impacto ambiental, além de proporcionar conforto térmico e acústico para residência.

A estrutura metálica respeita uma malha de 1,25 x 1,25 m2. Os espaços foram criados a partir desta modulação.

A organização espacial acontece em terraços que se lançam sobre a floresta, em busca de iluminação natural. Os ambientes se distribuem em três pisos: no térreo, uma célula independente com quarto, banheiro e cozinha. No primeiro piso, sala de estar, jantar, biblioteca, cozinha e lavabo. No segundo piso, dois quartos e dois banheiros.

A divisões internas foram projetadas com o objetivo de criar um espaço flexível, com possibilidade de se absorver a futuras mudanças. A adaptabilidade dos ambientes a diversas funções confere a esta arquitetura um caráter evolutivo.

\subsection{Implantação e relação com o entorno}

A construção procurou adaptar-se ao máximo às características topográficas do sítio, um terreno com 14 metros de declive a partir da rua e densa vegetação. $O$ acesso é feito pela cota mais alta do terreno, deixando os fundos da residência voltado para o bosque - apoiado sobre pilotis. 
A residência é composta por dois volumes retangulares que se encontram transversalmente, sendo que o principal está posicionado longitudinalmente em relação à inclinação do lote.

O projeto possui diversos terraços e sacadas que se lançam sobre o bosque como mirantes e mediadores entre o interior/exterior da residência. Estes espaços permitem a extensão dos ambientes da residência e sua integração com a natureza ao redor.

O volume principal possui grandes superfícies de vidro que favorecem a iluminação natural e refletem a natureza ao redor: cores, luzes e sombras do bosque invadem a obra. A escolha da madeira para o piso interno e varandas complementam e enriquecem o diálogo com o entorno.

\subsection{Programa de atividades}

O projeto distribui os espaços internos em três pavimentos e procura separar as áreas íntimas e social da casa. No pavimento térreo, através do qual é feito o acesso de veículos e pedestres, encontra-se a garagem e um setor independente da residência para hóspedes, com quarto, banheiro e mini copa.

$\mathrm{O}$ acesso ao segundo pavimento é feito através de uma escada que parte de um pequeno hall no térreo até o estar/refeições do primeiro pavimento. Este ambiente é caracterizado pela amplitude do pé-direito duplo e pela abundante iluminação natural, obtida através das grandes superfícies de vidro com vista para o bosque. A luz do sol, que invade a sala por entre as árvores, e a escolha do piso de madeira, faz deste espaço o mais aconchegante da casa.

Ainda neste piso, existe uma cozinha aberta, separada da área de refeições apenas por um balcão de meia-altura, e o escritório/biblioteca.

O terceiro pavimento corresponde à área íntima da casa. Além da ampla suíte do casal, com closet e varanda voltada para o bosque, há uma suíte menor, que corresponde ao volume transversal ao bloco principal e tem vista simultaneamente para o bosque dos fundos e para a rua de acesso. 


\subsection{Partido arquitetônico}

A casa tira partido da densa vegetação do terreno e é projetada com o objetivo de interferir o mínimo possível nas características originais do sítio. Partindo desta premissa, foi escolhido o sistema construtivo que causaria menor impacto e possibilitaria uma obra de construção rápida e limpa - estrutura metálica e chapas de concreto com interior em poliuretano.

É interessante destacar neste projeto que toda sua concepção ocorre em torno da tecnologia construtiva escolhida, buscando a flexibilidade dos espaços através de uma rede de instalações homogênea - água, energia, luz - atitude que o relaciona diretamente com a arquitetura que busca a saída pela alta tecnologia. Contudo, a relação desta obra com a arquitetura high tech parte de uma postura ecológica do arquiteto, buscando minimizar o impacto da obra no meio onde se insere.

Além de preservar o entorno, o partido procura trazer as características deste para o interior da residência. Por este motivo, optou-se por abrir o projeto para o ambiente ao redor através de grandes superfícies envidraçadas, para que a iluminação e ventilação do interior da residência compartilhassem características semelhantes ao próprio bosque.

Além dos planos de vidro, todos os pavimentos da construção possuem terraços e sacadas, que possibilitam a expansão dos ambientes e a integração destes com a natureza do entorno.

\subsection{Sistema construtivo}

Os projetos revelam um detalhamento minucioso das soluções construtivas e dos acabamentos, enfatizando o trabalho intencional e rigoroso sobre o objeto arquitetônico.

A estrutura metálica fica aparente, tanto externa quanto internamente, e divide-se em uma modulação de 1,25 por 1,25m. Os espaços internos distribuem-se respeitando esta malha. 
Os planos externos, definidos por esta modulação, alternam os tipos de fechamento, ora dando lugar a superfícies opacas definidas pelas chapas de concreto pintadas de branco, ora caracterizados pela transparência das grandes áreas envidraçadas. Os terraços e sacadas que se desprendem do bloco principal avançam em direção ao bosque também se adaptam a esta modulação.

\subsection{Intenção Plástica}

O projeto tira partido plástico dos elementos de estrutura e fechamento da obra. A opção pela manutenção dos elementos de estrutura metálica e chapas de concreto aparentes, ambos com acabamento em pintura na cor branca, afirmam um compromisso ético-estético com o que constituiria a "verdade" construtiva do objeto arquitetônico. A vigas e pilares aparentes revelam de forma didática o modo como o edifício foi construído.

Embora funcionalmente o projeto estabeleça uma relação de integração e continuidade visual com o entorno, plasticamente a obra se configura como objeto individual e autônomo. As formas ortogonais dos volumes brancos se impõem afirmativamente sobre a paisagem.

No interior da residência, a escolha dos materiais e mobiliário deixam clara a intenção da arquiteta em conceber um ambiente simultaneamente moderno e aconchegante. As superfícies brancas de fechamento dialogam de forma harmoniosa com o piso de madeira, planos de destaque vermelhos e com as cores fortes do mobiliário e objetos de arte espalhados pela casa. 


\section{CONCLUSÃO}

Este trabalho delineou um panorama da arquitetura atual de Curitiba, através do estudo da tipologia residencial da cidade e da análise detalhada de oito residências construídas na última década. O objetivo desta pesquisa foi identificar tendências e correntes arquitetônicas disseminadas na arquitetura local, buscando compreender sua evolução, sua contextualização com a história da arquitetura da cidade e sua relação com a arquitetura contemporânea do Brasil e de outros países. Este estudo não tem a pretensão de encerrar o debate sobre a arquitetura curitibana, e sim, abrir portas e servir como fonte de dados para trabalhos futuros.

\subsection{A arquitetura e a cidade}

Curitiba é mais conhecida pelo seu planejamento urbano do que pela sua arquitetura. Entretanto, analisando o histórico da arquitetura de Curitiba, foi possível observar que a arquitetura sempre teve papel essencial na afirmação cultural e política da capital. A história da arquitetura da cidade é pontuada por fatos e personalidades marcantes, não raras vezes ligadas a política. Nesse contexto, é essencial mencionar: o governo Munhoz da Rocha, que determinou a construção de diversas obras influenciadas pela arquitetura do Movimento Moderno - Biblioteca Pública, Teatro Guaíra, Centro Cívico - em comemoração ao centenário paranaense; a fundação do curso de arquitetura da Universidade Federal do Paraná, trazendo arquitetos de todo país para lecionar em Curitiba, e que, através de sua atividade profissional na cidade, marcaram a capital com obras e projetos particularmente da tipologia residencial - de qualidade singular; a atuação de Jaime Lerner na prefeitura da cidade e do governo do estado, implantando projetos urbanísticos que fizeram com que Curitiba se tornasse exemplo internacional de planejamento urbano; e finalmente, a arquitetura institucional dos anos 90, marcada pelo uso de troncos de madeira e alinhada com o debate sobre arquitetura sustentável e preservação do meio ambiente.

A arquitetura atual de Curitiba - da mesma forma que boa parte da arquitetura construída em outros países - é resultado de anos de debate entre 
modernidade e pós-modernidade e do amadurecimento de propostas teóricas que, particularmente após a década de 80 , buscam de alguma forma legitimizar a arquitetura. Correntes teóricas relacionadas ao uso alta-tecnologia, ao contextualismo cultural, ecologia e sustentabilidade, minimalismo, entre outras, passaram a apresentar propostas teóricas definidas e delinear o perfil da arquitetura contemporânea.

\subsection{A escolha das residências}

A escolha tipologia residencial como objeto de estudo ocorreu por ser a tipologia arquitetônica na qual o arquiteto tem maior liberdade de trabalhar e desenvolver suas ideias de projeto. A análise detalhada das oito residências selecionadas para este trabalho teve como objetivo identificar os princípios compositivos, construtivos, tecnológicos, formais e estéticos, de obras singulares consideradas essenciais para a compreensão da arquitetura atual de Curitiba.

Desta forma, a escolha dos projetos procurou identificar exemplos relevantes para o contexto cultural da cidade e que pudessem representar a arquitetura de Curitiba nos anos 2000. A pré-seleção das obras foi feita através de três etapas: pesquisa realizada com arquitetos, professores e profissionais relacionados com a área, com o objetivo de identificar não somente obras e profissionais relevantes para o panorama da cidade, mas também compreender a visão dos próprios curitibanos sobre sua arquitetura; pesquisa em jornais, revistas e periódicos, buscando uma visão da arquitetura de Curitiba não somente através dos arquitetos e população local, mas também num contexto mais amplo; e por fim, o levantamento dos resultados de concursos de projeto realizados nas últimas duas décadas, procurando identificar quais escritórios e arquitetos de Curitiba tiveram destaque nestas premiações.

\subsection{A análise dos projetos}

Para a análise das obras selecionadas, partiu-se do pressuposto da existência de elementos básicos que, por sua permanência ao longo da história da 
arquitetura, configurariam bases sólidas na definição de tópicos para a avaliação das obras. Estes elementos, denominados neste trabalho como operadores pragmáticos seriam: o uso, o lugar arquitetônico, a técnica construtiva e as narrativas formais. $A$ partir destes operadores foram definidos seis tópicos que serviram como roteiro de análise para as residências.

A análise das residências e a contextualização das obras locais com as principais linhas de pensamento da arquitetura internacional levam a conclusão que a arquitetura da capital paranaense, embora não configure um conjunto coeso de obras a ponto de poder ser considerado um dos grandes centros de produção arquitetônica do país, apresenta, ainda que pontualmente, exemplos que dialogam com as tendências contemporâneas e obras significativas e essenciais na compreensão do panorama arquitetônico do Brasil.

As residências analisadas neste trabalho evidenciam o comprometimento de um grupo de profissionais na concepção de obras que não apenas trazem conceitos e pensamentos das correntes contemporâneas da arquitetura, mas também buscam o diálogo e a adaptação destas linhas de pensamento com o entorno imediato e contexto local. São arquiteturas singulares, que além de discutir ideias debatidas pelas principais escolas de arquitetura do mundo, interpretam estes conceitos de modo específico para o contexto onde se inserem. São obras que não se configuram apenas como solução de um programa específico ou necessidades de um usuário, mas sim pela legitimização de sua importância não apenas como construção, mas como arquitetura. São obras que sintetizam um conjunto de ideias e propostas teóricas definidas, propondo novas formas de ver e compreender a arquitetura e abrindo portas para a continuidade do debate arquitetônico.

\subsection{Curitiba e o debate teórico internacional}

A partir da análise das residências, foi possível concluir que algumas linhas de pensamento contemporâneo têm uma influência mais clara sobre a arquitetura residencial da cidade.

Ao longo dos anos 80 e parte da década de 90, desenvolveu-se em Curitiba uma arquitetura classificada pelo arquiteto e historiador Irã Dudeque como "uma 
arquitetura de poucos substantivos e muitos adjetivos". O panorama da cidade foi marcado pela presença colunas e frontões, inicialmente considerados como exemplos de arquitetura "neoclássica", notáveis pela pobreza estrutural escondida por revestimentos de baixa qualidade. Após uma análise mais atenta desta arquitetura de suposta influência "neoclássica" que marcaram Curitiba nas últimas décadas, é necessário ressaltar a maioria destas obras pouco ou nada tem a ver com correntes de pensamento ligadas ao historicismo revival, ecletismo ou contextualismo cultural. São esquematismos imobiliários que não hesitam em utilizar de maneira literal as linguagens do passado. Frontões triangulares, colunas e outros elementos da linguagem clássica voltam a aparecer diretamente sem nenhuma vontade de experimentação, reelaboração ou abstração, senão que aproveitam ao máximo a corrente de aceitação popular que gera a recriação de convenções.

Por outro lado, observa-se que na arquitetura de Curitiba, assim como em grande parte da arquitetura brasileira atual, ainda é amplamente influenciada por tendências relacionadas com a revisão do que com a quebra do discurso do Movimento Moderno.

Essas tendências, além de buscar novas soluções e caminhos para a arquitetura, diversas vezes caracterizam-se pelo resgate do conteúdo conceitual próprio do movimento moderno, tomando por base seus princípios, mas revendo alguns conceitos, com objetivo de adaptar a obra a uma condição específica. Não como um revival estilístico, mas uma nova organização de elementos compositivos baseada na busca por novos conceitos característicos da contemporaneidade, como: articulação, interpenetração, interação, decomposição, descontinuidade e transparência.

No Brasil, uma reavaliação segundo uma óptica da condição pós-moderna, todavia, não significou a implantação de uma arquitetura pós-moderna. [...] A atual contestação à arquitetura moderna brasileira atinge seus mitos, não seus princípios. ${ }^{30}$

\footnotetext{
${ }^{30}$ Segawa, Hugo. Arquiteturas no Brasil: 1900-1990. São Paulo, Edusp, 1997.
} 
Portanto, a herança modernista é um fator que não pode ser desconsiderado na arquitetura brasileira. Assim, como ocorre em diversos países europeus fortemente marcados pelo modernismo, o Brasil tende a apresentar, predominantemente, uma arquitetura caracterizada pela continuidade, e não pela ruptura do Movimento Moderno, valorizando a adequação às características particulares do contexto urbano onde se insere, a adequação climática e a coerência construtiva. A releitura das obras do período áureo da arquitetura brasileira aparece com frequência não com o intuito de cópia, mas de resgate dos conteúdos culturais, ideológicos e estéticos que, caracterizaram a arquitetura brasileira em um momento histórico.

Isso pode ser observado claramente em algumas das residências analisadas neste trabalho, em particular nos projetos dos escritórios Studio Bertoldi, Z Arquitetura, Átrio Arquitetura, Una. No projeto do escritório Studio Bertoldi, é evidente a influência da arquitetura de Mies van der Rohe e o resgate de elementos da arquitetura residencial de Curitiba das décadas de 60 e 70. Mas também observamos em alguns posicionamentos de projeto influência da nova abstração formal. $O$ mesmo ocorre nas residências dos escritórios Una e $Z$ arquitetura. Apesar de ambos apresentarem influências da arquitetura corbusiana - janelas em fita, uso da cor branca, emolduração da paisagem - a austeridade das formas e o diálogo com o entorno deixam claro no projeto do Una a influência da arquitetura minimalista, enquanto o projeto do $Z$ Arquitetura nos remete as obras do arquiteto norte-americano Richard Meyer.

Situação semelhante ocorre na residência do escritório Átrio Arquitetura: embora os volumes ortogonais, a fluidez do espaço interno e a opção por deixar elementos construtivos aparentes - como no caso das chaminés da lareira e churrasqueira - nos remetam as vanguardas do início do século, o tratamento das fachadas, o trabalho artesanal com o revestimentos em petit pavé, a concepção das aberturas e tratamento da volumetria são aspectos que se relacionam mais diretamente com o paradigma da obra de arte. Já na residência projetada pelo grupo Central de Projetos, observamos que enquanto as outras residências citadas seguem uma linha mais racionalista, esta residência apresenta aspectos mais próximos de arquitetura de Frank Lloyd Wright. A maneira como se integra de forma 
harmônica com o entorno, a escolha de materiais e cores que tornam a arquitetura parte da paisagem.

A saída pela alta tecnologia, embora tenha nítida influencia em obras comerciais e edifícios de escritório, não é observada de forma muito clara na arquitetura residencial, com exceção da casa da arquiteta Daniela Busarello que tira partido da tecnologia na concepção do seu projeto.

A obra de reciclagem do antigo moinho do arquiteto Gustavo Pinto é um caso a parte dentro deste trabalho. Em primeiro lugar, por ser a única das obras analisadas que parte de uma construção já existente. Desta forma, observa-se no projeto a intenção de se contextualizar não somente com o entorno, mas em especial com a construção antiga, inclusive deixando elementos do moinho original a mostra, evidenciando as técnicas de projeto e função original da construção já existente.

Embora poucas obras analisadas possam ser caracterizadas como "arquitetura ecológica" - com exceção da casa projetada pela arquiteta Andréa Berriel, um excelente exemplo de associação de conceitos de sustentabilidade com uso de tecnologias e materiais locais - pode-se observar que em todas as residências a preocupação com adequação ambiental do projeto. Aproveitamento de insolação e ventos dominantes, adequação as características topográficas do terreno, reaproveitamento de água, instalação de placas solares como meio alternativo de gerar energia, entre outros, são algumas das diretrizes de projeto observadas nas obras analisadas que demonstram uma tendência a sustentabilidade nas obras de Curitiba.

Acredita-se que esta tendência não seja resultado unicamente do debate internacional sobre sustentabilidade, e sim reflexo da própria história da cidade. Quando o planejamento urbano de Curitiba tornou-se referência no Brasil, a questão ambiental tornou-se um dos aspectos marcantes da proposta urbanística e a cidade ganhou o título de "capital ecológica". Embora até hoje esse título seja em parte questionado por arquitetos e mesmo pela população da cidade, que vêm esse viés ecológico do urbanismo de Curitiba mais como "estratégia de marketing" do que como soluções práticas, o fato é que essa diretriz influenciou toda a arquitetura da cidade, em especial a arquitetura institucional dos anos 90. Reciclagem de lixo, 
preservação das áreas de manancial, campanhas para economia de água e energia, fazem parte do cotidiano da cidade e invariavelmente refletiram na sua arquitetura.

Outro aspecto marcante - e também contraditório com o título de "referência de planejamento urbano internacional“ - é a questão dos condomínios fechados. Desde o início dos anos noventa, o tecido urbano da "capital ecológica" vem sendo fragmentado pela implantação de condomínios fechados de luxo em diversas regiões da cidade. Até esta década, a dimensão destes condomínios não era tão expressiva, sendo sua infraestrutura limitada a um conjunto de casas com acesso privado, defendo a ideia desta forma aumentaria a segurança em relação a residências construídas em vias públicas. A partir da implantação do Alphaville Graciosa, diversos condomínios de grande porte se instalaram na cidade, visando não somente a segurança das residências, mas também independência - parcial da estrutura da cidade. Além da área residencial, estes empreendimentos dispõem de clubes, associações, creches, escolas, restaurantes, e em muitos casos legislação própria determinando os parâmetros construtivos dentro do condomínio.

A proliferação dos condomínios fechados em Curitiba fica ainda mais clara quando observamos os números desta pesquisa: na etapa de pré-seleção, $78 \%$ das residências se situavam em condomínios fechados. Das oito residências escolhidas para a análise final, cinco encontram-se nestes condomínios - Una, Studio Bertoldi, Átrio Arquitetura, Central de Projetos, Z Arquitetura. Nestes casos, não foi possível avaliar a relação destes projetos contemporâneos com o entorno e a realidade urbana da cidade - uma vez que eles se relacionam com o entorno utópico e controlado dos condomínios.

\subsection{Considerações finais}

A produção contemporânea local não pode ser considerado como único fator responsável pela qualidade ou força motora para o desenvolvimento da arquitetura em Curitiba - ou de qualquer outra cidade do mundo.

Iniciativas - ainda que pontuais - de acompanhar o discurso de escolas envolvidas no debate arquitetônico e alinhadas com as principais tendências contemporâneas internacionais já é um fator positivo para o desenvolvimento da 
arquitetura de uma cidade/região, mas existem outros fatores: qualidade do ensino superior de arquitetura nas universidades, eventos relacionados com arquitetura contemporânea, cultura arquitetônica da população, posicionamento e diretrizes do governo e órgãos públicos dando espaço a projetos com ideias renovadoras que contribuam para o desenvolvimento da boa arquitetura e urbanismo na cidade.

Com relação ao ensino superior, atualmente Curitiba conta cinco Universidades que ofertam o curso de graduação em Arquitetura e Urbanismo, sendo duas Federais - a Universidade Federal do Paraná (UFPR) e a Universidade Tecnológica Federal do Paraná (UTFPR) e três privadas - a Pontifícia Universidade Católica do Paraná (PUC-PR), Universidade Tuiuti do Paraná (UTP) e Universidade Positivo (UP).

Destas cinco universidades, apenas duas ofertam cursos strictu sensu relacionados com arquitetura e urbanismo: a PUC-PR oferta cursos de mestrado e doutorado em Gestão Urbana e a Universidade Positivo possui cursos de mestrado e doutorado na área de Gestão Ambiental. Ambas as universidades possuem cursos de especialização em diferentes áreas de arquitetura e urbanismo.

A UFPR e a UTP não apresentam nenhum curso strictu sensu relacionado com seus respectivos departamentos de Arquitetura e Urbanismo. A UFPR possui um curso de especialização em Geoprocessamento ligado ao setor de Tecnologia. A UTP possui um curso de Sustentabilidade e Gestão Ambiental, mas relacionado com o departamento de Ciências Sociais Aplicadas (o curso de Arquitetura e Urbanismo da faculdade está vinculado ao departamento de Ciências Exatas e de Tecnologia). A UTFPR não apresenta cursos de especialização na área.

O número de eventos promovidos pelo IAB, CREA e outros órgãos ligados à arquitetura foi escasso nas últimas décadas. A agenda da cidade se resumiu a lançamentos de livros de arquitetura, exposições de resultados de concursos de projeto, debates e seminários (geralmente relacionados com urbanismo e gestão ambiental) e algumas palestras.

A falta de conhecimento e de divulgação da boa arquitetura da cidade, associada ao apelo do mercado imobiliário para padrões e conceitos conhecidos da população, faz com que a arquitetura média da cidade ainda seja de qualidade duvidosa. Neste aspecto, este projeto tem a intenção não somente de divulgar a 
arquitetura de qualidade produzida nas últimas décadas, mas também chamar a atenção para a importância de recuperar parte da memória da arquitetura da cidade e tentar impedir que alguns equívocos do passado aconteçam novamente. Evitar que criadores singulares como Kirchgässner sejam esquecidos e valorizados somente após sua morte, quando já é impossível compreender boa parte de suas referencias, influencias e ensinamentos. Ou ainda, como no caso de algumas obras de Lolô Cornelsen e Oswald Bratke, a falta de conhecimento e cultura arquitetônica resulte na demolição de seus projetos - infelizmente um dos mais importantes e representativos da cidade - valorizados somente poucas semanas antes de serem destruídos.

Espera-se ainda que esse trabalho possa servir como fonte de informação e/ou complemento para estudos da arquitetura local com outros enfoques - histórico, social, político, cultural - com a perspectiva que a inter-relação entre estes estudos possa nos fornecer uma compreensão mais clara e abrangente sobre arquitetura de Curitiba. 


\section{REFERÊNCIAS BIBLIOGRÁFICAS}

- $\quad$ ACAYABA, Marlene Milan. Residências em São Paulo: 1947 - 1975. São Paulo: Projeto, 1986.

- $\quad$ ACAYABA, Marlene Milan. Residências em São Paulo: 1950 - 1970 (Tese de Doutoramento). São Paulo: Projeto Editores, 1986.

- $\quad$ ARGAN, Giulio Carlo. Projeto e destino. Rio de Janeiro: Editora Ática, 2000.

- CHOAY, Françoise. O Urbanismo: utopias e realidades. Uma antologia São Paulo: revista Perspectiva, 1992.

- COLLINS, Peter. Los Ideales de la arquitectura moderna, su evolución (17501950). Tradução: Ignasi de Solà-Morales. Barcelona: Gustavo Gili, 1998.

- COLQUHOUN, Alan. Typology and design method, 1967. In NESBITT, Kate (editor). Theorizing a new agenda for architecture: an anthology of architectural theory 1965-1995. Nova Iorque: Princeton Architectural Press, 1996.

- $\quad$ COULQUHOUN, Alan. Modernidad y tradición clásica. Trad. Ramón Martinez Castellote. Madrid, Ediciones Júcar, 1991.

- $\quad$ FOSTER, Norman. Reflections. London: Prestel Publishing, 2005.

- FOSTER, Norman. Foster + Partners: Catalogue. New York: Prestel USA, 2008.

- $\quad$ FRAMPTON, Kenneth. História crítica da arquitetura moderna. São Paulo: Martins Fontes, 1997.

- FRAMPTON, Kenneth, MALGRAVE, Harry Francis. Studies in tectonic culture: the poetics of construction in nineteenth and twentieth century architecture. Cambridge: MIT Press, 2001.

- GADAMER, Hans-Georg. Verdade e método - traços fundamentais de uma hermenêutica filosófica. Petrópolis: Vozes, 1998.

- GOMBRICH, E.H. Arte e ilusão. São Paulo: Martins Fontes, 1986.

- GOMBRICH, E.H. História da arte. Rio de Janeiro: Guanabara, 1978.

- GRASSI, Giorgio. La costruzione logica dell'architettura. Milão: Franco Angeli, 2008.

- GRAVES, Michael. A case for figurative architecture, 1982. In NESBITT, Kate (editor). Theorizing a new agenda for architecture: an anthology of architectural theory 1965-1995. Nova Iorque: Princeton Architectural Press, 1996. 
- GREGOTTI, Vittorio. Territory and Architecture, 1985. In: Theorizing a new agenda for architecture: an anthology of architectural theory 1965-1995. Nova lorque: Princeton Architectural Press, 1996.

- HABERMAS, Jurgen. Arquitetura moderna e pós-moderna, 1987. In ARANTES, Otília. Um ponto cego no projeto moderno de Jurgen Habermas. São Paulo: Edições Loyola, 1992.

- JENCKS, Charles. El lenguaje de la arquitectura posmoderna. Barcelona: Gustavo Gili, 1981.

- KRUFT, Hanno-Walter. A history of architectural theory - from Vitruvius to the present. Londres: Zwemmer; Nova lorque: Princeton Architectural Press, 1994.

- LEFEBVRE, Henry. The production of space. Padstow: T.J. Press, 1992.

- LYNCH, Kevin. A imagem da cidade. São Paulo: Martins Fontes, 1999.

- LYOTARD, Jean-François. The postmodern condition. Manchester: Manchester University Press, 1984.

- MAHFUZ, Edson. Reflexões sobre a construção de forma pertinente, 2003. In LARA, Fernando, MARQUES, Sônia. Projetar: desafios e conquistas da pesquisa e do ensino de projeto. Rio de Janeiro: EVC, 2003.

- MAHFUZ, Edson. Quem tem medo do pós-modernismo? São Paulo: revista Projeto n. 101, pg. 132.

- MEARlEAU-PONTY, Maurice. Fenomenologia da Percepção. São Paulo: Livrarias Freitas Bastos, 1971.

- MONTANER, Josep Maria. Después del Movimiento Moderno. Arquitectura de la Segunda Mitad del Siglo XX. Barcelona: Gustavo Gili, 1993.

- MONTANER, Josep Maria. La Modernidade Superada. Arquitectura: Arte y Pensamiento del Siglo XX. Barcelona: Gustavo Gili, 1997.

- NORBERG-SCHULZ, Christian; DIGEROUD, George. Louis I. Kahn, idea e imagem. Madri: Xarait, 1981.

- NORBERG-SCHULZ, Christian. Genius Loci - towards a phenomenology in architecture. New York: Rizzoli, 1984.

- NORBERG-SCHULZ, Christian. Arquitectura occidental. Barcelona: Gustavo Gili, 1983. 
- OHTAKE, Ruy. Arquitetura e a Cidade. São Paulo: Instituto Tomie Ohtake, 2011.

- PEdrosA, Mario. Mundo, Homem, Arte em Crise. São Paulo: Perspectiva, 1975.

- PEDRosA, Mario. Dos murais de Portinari aos espaços de Brasília. São Paulo: Perspectiva, 1981.

- ROGERS, Richard. Cidades para um pequeno planeta. Barcelona: Gustavo Gili, 2005.

- ROSSI, Aldo. A arquitetura da cidade. São Paulo: Martins Fontes, 1995.

- SANTA CECÍlIA, Bruno Luiz Coutinho. Complexidade e Contradição na Arquitetura Brasileira: A Obra de Éolo Maia (Dissertação de Mestrado, Universidade Federal de Minas Gerais. Orientador: Prof. Dra. Maria Lúcia Malard). 2004

- SEGAWA, Hugo. Arquiteturas no Brasil: 1900-1990. São Paulo: Edusp, 1997.

- TAFURI, Manfredo. Teorias e história da arquitetura. Lisboa: Presença, 1988.

- TEDESCHI, Enrico. Teoria de la arquitectura. Buenos Aires: Nueva Visión, 1980.

- VENTURI, Lionello. História da Crítica de Arte. Lisboa: Almedina, 2007.

- VENTURI, Robert. Complexidade e contradição em arquitetura. São Paulo: Martins Fontes, 1995, Tradução Álvaro Cabral (1a ed. 1996).

- VITRUVIO, Marco Lucio. Da Arquitetura. São Paulo: Hucitec, 1999.

- WILSON, Colin St John. The play of use \& the use of play. In Architectural Review, julho, 1986, p. 15-8. 